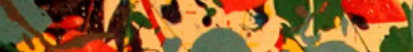

$-4$ 



\section{A Avenida de mil vias: \\ Conflito, contradição e ambivalência na modernização de São Paulo (1890-1920)}

Pedro Beresin Schleder Ferreira Orientação: Profa. Dra. Ana Lucia Duarte Lanna

Dissertação apresentada para obtenção do título de Mestre no Programa de Pós-Graduação em Arquitetura e Urbanismo da Faculdade de Arquitetura e Urbanismo da Universidade de São Paulo

Área de concentração: História e Fundamentos da Arquitetura e do urbanismo

São Paulo, 2017

EXEMPLAR REVISADO E ALTERADO EM RELAÇÃO À VERSÃO ORIGINAL, SOB RESPONSABILIDADE DO AUTOR E ANUÊNCIA DO ORIENTADOR. O original se encontra disponível na sede do programa. São Paulo, 05 de junho de 2017. 
Autorizo a reprodução e divulgação total ou parcial deste trabalho, por qualquer meio convencional ou eletrônico, para fins de estudo e pesquisa, desde que citada a fonte.

Ferreira, Pedro Beresin Schleder A Avenida de mil vias: conflito, contradição e
ambivalência na modernização de São Paulo (1890-1920)

F 383a / Pedro Beresin Schleder Ferreira; orientadora Ana Lúcia Duarte Lanna. - São Paulo, 2016.

308 .

Dissertação (Mestrado) - Faculdade de Arquitetura e Urbanismo da Universidade de São Paulo. Área de concentração: História e Fundamentos da Arquitetura e Urbanismo

1. São Paulo. 2. Modernidade. 3. Conflito Social. 4. Higienópolis. I. Lanna, Ana Lúcia Duarte, orient. Ii. Título. 


\section{A Avenida de mil vias: \\ Conflito, contradição e ambivalência na modernização de São Paulo (1890-1920)}

\section{Pedro Beresin Schleder Ferreira}

Dissertação apresentada para obtenção do título de Mestre no Programa de PósGraduação em Arquitetura e Urbanismo da Faculdade de Arquitetura e Urbanismo da Universidade de São Paulo na área de concentração de História e Fundamentos da Arquitetura e do urbanismo.

Aprovado em:

Banca Examinadora:

Prof. Dr. Instituição:

Julgamento: Assinatura:

Prof. Dr. Instituição:

Julgamento: Assinatura:

Prof. Dr. Instituição:

Julgamento: Assinatura: 

Para Ruth, Daniel e Nelson (in memoriam) - meus primeiros pontos cardeais 

Sempre senti atração por esse pequeno espaço: o ser humano... Um ser humano. Na verdade, é lá que tudo acontece. Svetlana Aleksiévitch, O fim do Homem Soviético

A Avenida Angélica não é reta. José Oswald de Andrade

Ser e não ser: eis a solução.

Antunes Filho 



\section{Resumo}

Este trabalho tem como objetivo deslindar consensos e firmar interpretações para o "fazer-se" da cidade de São Paulo a partir da consideração das múltiplas dinâmicas, relações, estratégias, confluências e disputas que foram articuladas pela ampla gama de agentes envolvidos nesse imbricado processo. Não à toa escolhemos a Avenida Angélica, das décadas de 1890 a 1920, como objeto. Sobre ela incide na historiografia uma imagem monolítica, que reitera a explicação da modernização de São Paulo como a vitória plena e triunfante de um projeto consensual das elites. Sendo assim, trata-se de um palco privilegiado para observarmos as tensões, fissuras e incongruências ocultadas por essa homogeneidade construída e darmos passos em direção a outros caminhos explicativos possíveis.

Para tanto, nos valemos de vasto corpus documental que nos permitiu penetrar em diversos âmbitos e dimensões do processo de consolidação e vivência da Avenida. Através das atas camarárias, pedidos de obras, jornais e cartografias, adentramos em seu espaço-tempo a partir de quatro perspectivas: as agitações de seu mercado de terras e imóveis, os conflitos no estabelecimento de regulamentações construtivas, as ambivalentes experiências e expectativas diante de seu "progresso" e as múltiplas relações sociais, materiais e econômicas envolvidas no chão de sua vida cotidiana. Por meio dessas, descobrimos que ali, lado a lado com os anseios exibitivos e segregativos das elites e do Estado, habitavam as ruas, batalhavam por suas estratégias e direitos, desenvolviam suas vidas e erguiam suas residências os mais diversos membros dos setores médios e trabalhadores da cidade. Percebemos que os grupos e classes tampouco eram estanques, mas homogêneos e heterogêneos, fraternos e competitivos, de uma só vez. Isso porque os interesses públicos e privados de seus membros, fossem das elites ou dos menos apossados, variavam de acordo com as circunstancias.

Essas oscilações nos anseios e nas conjunturas tornavam o "fazer-se" da Avenida um dinâmico mosaico de fronteiras. Limiares multidimensionais, que eram entrecruzados pelos universos das relações sociais, materiais e simbólicas. Longe de configurarem "muros", as fronteiras eram cambiantes e de consistência variada. Quando porosas, configuravam espaços de associação e negociação entre os agentes. Quando cerradas, tornavam-se limiares de rijos conflitos, disputas e tensões. Em suas bordas, encontros e desencontros conformaram um "fazer-se" irrequieto, plural e movediço. Longe de ser plena, a Angélica era uma encruzilhada, onde encontravam-se os desejos, táticas e práticas da ampla e variada gama de seus habitantes, configurando uma modernização ambivalente, plural, imbricada. Ao invés de unívoca e retilínea, era uma Avenida de mil vias tensas e entremeadas.

Palavras-chave: São Paulo; modernidade; conflito social; Higienópolis. 

This work aims at establishing consensus and establishing interpretations for the "making" of the city of São Paulo based on the consideration of the multiple dynamics, relationships, strategies, confluences and disputes that were articulated by the wide range of agents involved in this imbricated process. No wonder we chose Avenida Angelica, from the 1890s to the 1920s, as an object. Under it historiography has a monolithic image, which reiterates the explanation of the modernization of Sao Paulo as the full and triumphant victory of a consensual project of the elites. Thus, it is a privileged stage to observe the tensions, fissures and incongruities hidden by this constructed homogeneity and to take steps towards other possible explanatory paths.

To do so, we used a vast documentary corpus that allowed us to penetrate into various scopes and dimensions of the process of consolidation and experience of the Avenue. Through the city councils, requests for works, newspapers and cartographies, we enter into its space-time from four perspectives: the agitations of its land and real estate market, the conflicts in the establishment of constructive regulations, the ambivalent experiences and expectations before it's "progress", and the multiple social, material, and economic relationships involved in the ground of his daily life. Through these we discovered that there, side by side with the exhibition and segregative yearnings of the elites and the state, they inhabited the streets, fought for their strategies and rights, developed their lives, and erected their residences, the most diverse members of the middle and City workers. We realized that the groups and classes were not watertight, but homogeneous and heterogeneous, fraternal and competitive, all at once. This was because the interests, public and private, of its members, were of the elites or of the lesser ones, varied according to the circumstances.

These oscillations in yearnings and conjunctures made the "making-up" of the Avenue a dynamic mosaic of frontiers. Multidimensional thresholds, which were intersected by the universes of social, material and symbolic relations. Far from forming "walls", the boundaries were changing and of varying consistency. When porous, they formed spaces of association and negotiation among agents. When closed, conflicts, disputes, and tensions became thresholds. At their edges, encounters and disagreements formed a restless, plural and unstable "making itself". Far from being full, Angelica was a crossroads, where the desires, tactics and practices of the wide and varied range of its inhabitants were found, forming an ambivalent, plural, overlapping modernization. Rather than univocal and straight, it was an avenue of thousand strained and interspersed streets.

Keywords: São Paulo; modernity; social conflict; Higienópolis 



\section{Sumário}

Introdução, 17

Cap. 1 Sinuosos interesses, intrincadas materialidades, 39

Retornar ao Éden: um loteamento exclusivo, 41

Um sonho lento e turbulento: uma ocupação errante, 54

O sacolejo do paraíso: disputas em torno de uma lei, 68

Crer para ver: o poder da representação, 78

Cap. 2 Vias de mão dupla, 89

Para além dos jardins, à beira dos portões: a fronteira, 91

O assombroso maquinário do progresso, 96

Em pleno passeio, a velocidade acachapa os palacetes, 114

Cap. 3 A bucólica passarela das elites, 119

Três mundos... entrelaçados, 121

Lar, agridoce, lar, 123

“Dize-me como moras, e dir-te-ei quem és”, 133

Cap. 4 O trampolim dos remediados, 149

Cap. 5 O multiverso dos trabalhadores, 169

Opostos intrínsecos, 175

As fronteiras da cultura, os limiares da lei, 181

Irrequieta placidez, 191

Considerações Finais, 207

Caderno de Imagens, 219

Bibliografia, 293

Agradecimentos, 307 

Introdução 

As últimas décadas do século XIX foram avassaladoras para o mundo Ocidental. Decerto, a modernidade foi gestada na longa duração, desde meados do século XV, no Oeste europeu. Mas, como um vulcão, apesar de sua longa formação, teve suas grandes eclosões em momentos específicos e concentrados no espaço-tempo. Uma dessas colossais irrupções, como observou Nicolau Sevcenko, foi proporcionada pela Revolução Técnico-Científica (1850-1870), que levou a uma nova escala e profundidade a aplicação do conhecimento científico à produção industrial ${ }^{1}$. O alucinante incremento produtivo decorrente dessa fusão intensificou drasticamente a necessidade de expansão dos capitais europeus e norte-americanos. Daí a origem do neocolonialismo na África, na Oceania e no sul-asiático, movidos pela irrequieta busca das nações desenvolvidas por novas fontes de matéria-prima, oportunidades para o investimento financeiro e ampliação dos mercados de consumo para seus excedentes produtivos.

\footnotetext{
${ }^{1}$ SEVCENKO, Nicolau. O cosmopolitismo pacifista da Belle Époque: uma utopia liberal. In: Revista de História, n. 114, USP, São Paulo: janeiro-junho, 1983 e SEVCENKO, Nicolau. Introdução: o prelúdio republicano, astúcias da ordem e ilusões do progresso. In: NOVAIS, Fernando e SEVCENKO, Nicolau (org.). História da vida privada no Brasil - República: da Belle Époque à era do rádio. São Paulo: Companhia das Letras, 2006, p. 7-49.
} 
Embora com violência menos explícita, esse impulso expansionista também chegou às antigas colônias americanas, dentre as quais o Brasil, que passaria a incorporar o mercado internacional através de sua ascendente economia cafeeira, dinamizada em grande parte pela popularização do uso da bebida estimulante no crescendo produtivista dos países setentrionais ${ }^{2}$. No seu território de cultivo predominante à época, o Estado de São Paulo, empresas estrangeiras investiram na infraestrutura para a colheita e escoamento da produção; bancos aplicaram capitais, garantindo aos agricultores o crescimento da lavoura e o controle do preço das sacas; e o Estado acertou acordos de imigração com nações estrangeiras, aliviando as tensões sociais do centro-sul europeu e proporcionando grandes contingentes de mão de obra para o cultivo nacional.

A estreita relação da economia cafeeira com o além-mar, juntamente com o arrojo capitalista de seus agentes locais e forasteiros, ampliara a importância do meio urbano na região. Após algumas disputas com outras cidades paulistas, como Campinas e Santos, São Paulo consolidou-se, com grande apoio do Governo Provincial, como a

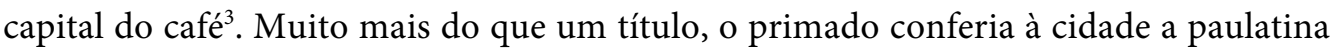
centralização das intermediações dos agentes econômicos com a administração pública, transações bancárias, negociações de levas, agenciamento de terras, contratação e recepção da mão de obra imigrante e ensacamento da produção. Para além do crescimento populacional, a configuração de capital econômica trouxe consequências ainda mais profundas à cidade. Da mesma maneira que a economia cafeeira mantinha relações estreitas com espaços distantes e invisíveis ao agente local, sua capital também foi atravessada por interesses alheios ao seu cotidiano, que tiveram forte impacto em sua conformação, tal qual nas trajetórias de seus habitantes.

A começar pelo interesse simbólico em seu espaço, através do qual as elites políticas e econômicas locais, em ascendente dominância no cenário nacional da

\footnotetext{
2 SEVCENKO, Nicolau. Orfeu extático na metrópole: São Paulo, sociedade e cultura nos frementes anos 20. São Paulo: Companhia das Letras, 1992, p. 107-108.

${ }^{3}$ CAMPOS NETO, Candido Malta. Os rumos da cidade: urbanismo e modernização em São Paulo. São Paulo: Ed. Senac, 2000, p.51-54 e LANNA, Ana Lúcia Duarte. Uma cidade na transição: Santos 18701913. São Paulo: Hucitec, 1995, p. 69-72.
} 
recém-proclamada República, ansiavam propagandear-se ao mundo desenvolvido. Consonantes com os ideais de solidariedade e interdependência entre as nações, promovidos pelos expoentes teóricos da economia de mercado e das teorias sociais do progresso, essas elites ambicionavam a inserção plena do Brasil no livre mercado internacional ${ }^{4}$. Seguindo esses pressupostos, o futuro do cosmopolitismo seria o crescimento proporcional e igualitário entre todos os seus componentes. Nas palavras de Sevcenko, tomando de empréstimo uma imagem veiculada em um jornal da época, sua utopia era a união das pátrias na forma de um imenso cristal, com as todas as faces lapidadas em idênticas proporções, conformando um objeto de perfeita e milimétrica simetria.

A convicção nesse destino compartilhado efervesceu o desejo das elites de incorporar essa sinfonia planetária. Não à toa, o Ecletismo, composto pela fusão harmônica de estilos, tipos e referências supranacionais, se tornou rapidamente uma das correntes arquitetônicas mais difundidas nesse tempo. Da mesma forma, crescia o anseio por tornar-se semelhante às grandes capitais do hemisfério norte - Paris, Londres e Nova York -, afinal, era ali que estavam todas as referências e expressões culturais do tão ambicionado progresso. Desejo esse conformado por uma intrincada trama de interesses, simbólicos e materiais, sem a qual é impossível compreender as noções primordiais e centrais das administrações urbanas brasileiras à época: os "melhoramentos" e "embelezamentos"5.

Para as nações do Norte, o desejo mimético austral consolidava uma gigantesca ampliação de mercado para toda a sorte de mercadorias produzidas em crescente parque industrial: desde materiais e projetos para grandes obras de infraestrutura até pequenas abotoaduras de paletó, passando pelo consumo cultural de livros, espetáculos e partituras musicais. Assim, juntamente com o poderio político, as teorias sociais do progresso também assentavam profícuas bases econômicas para os países

\footnotetext{
${ }^{4}$ SEVCENKO, 1983, p. 93.

${ }^{5}$ A perspectiva crítica quanto a essas noções utilizada aqui tem como base as reflexões de BRESCIANI, M. Stella. Melhoramentos entre intervenções e projetos estéticos: São Paulo (1850-1950). In: BRESCIANI, M. Stella (Org.). Palavras da cidade. Porto Alegre: Editora da Universidade/UFRGS, 2001, p. 343-366.; CERASOLI, Josianne Francia. Modernização no plural: obras públicas, tensões sociais e cidadania na passagem do século XIX para o XX. Tese (Doutorado) - IFCH-UNICAMP, 2004.
} 
desenvolvidos. Mobilizados em diversos âmbitos do poder internacional, essas vertentes do cientificismo, com referenciais assumidamente eurocêntricos, associavam diretamente o progresso social e cultural de uma nação ao seu domínio da razão e da técnica ${ }^{6}$. Colocando a modernidade europeia no ápice da civilização, seus produtos, instituições e meios tornavam-se obrigatórios a todos que pretendessem seguir o caminho unívoco do desenvolvimento.

No âmbito brasileiro, para além da crença e confiança de alguns agentes na potência redentora do cosmopolitismo, circundavam ainda interesses mais sólidos. Ao menos no caso do Rio de Janeiro e de São Paulo, as duas capitais em que estava centrado o projeto hegemônico das elites paulistas, os "melhoramentos" e "embelezamentos" que davam à sua vida feições europeizadas tinham suas mais profundas raízes na estabilização e crescimento da economia cafeeira. $\mathrm{Na}$ capital paulista, desde as primeiras intervenções de João Teodoro até a gestão de Washington Luís, as elites locais buscavam mitigar a hesitante desconfiança dos capitais internacionais em investir grandes montantes de capital em um país com desenvolvimento ainda incerto. Não à toa, essas ações têm seu primeiro ápice entre 1890 e 1910, época em que o Rio de Janeiro passa pelo faraônico intervencionismo da tríplice gestão de Pereira Passos, Lauro Müller e Oswaldo Cruz. Somados ao estigma do passado colonial e do preconceito étnico-racial, que assombraram toda a modernidade brasileira, os percalços desse período - sucessivas crises econômicas, provocadas primeiramente pelo Encilhamento e depois pelas consecutivas oscilações de preços do café no mercado internacional; crises políticas internas aos primeiros governos republicanos; revoltas militares e populares - colocavam as relações com as outras nações em perigo constante ${ }^{7}$.

$\mathrm{Na}$ ausência de indústrias de base e grandes instituições bancárias no país, a economia cafeeira corria eminente risco de colapso. Para evitá-lo, era necessário

\footnotetext{
${ }^{6}$ Cf. PESAVENTO, Sandra Jatahy. Exposições Universais: espetáculos da modernidade do século XIX. São Paulo: Hucitec, 1997 e BARBUY, Heloisa. A Exposição Universal de 1889 em Paris: visão e representação na sociedade industrial. São Paulo: Loyola; História Social USP, 1999.

${ }^{7}$ SEVCENKO, Nicolau. A revolta da vacina: mentes insanas em corpos rebeldes. São Paulo: Cosacnaify, 2010, p. 55-75.
} 
convencer técnicos, bancários, empresas e trabalhadores estrangeiros de que o país prosperava economicamente, que a ordem social estava estabelecida e suas instituições liberais, solidificadas. Sendo um dos maiores e mais pujantes artefatos erguidos pelo capitalismo industrial, não havia melhor palco para a exibição de grandes enunciados do que a própria cidade. Sobre esse pano de fundo, as imagens da cidade assumem proeminente papel na representação socioeconômica do país, atravessando o cotidiano de seus moradores com obras e ações que muitas vezes tinham como principal público pessoas totalmente alheias à sua espacialidade e cotidiano.

Conjuntamente ao universo simbólico, os "melhoramentos" também eram enraizados em desejos locais. Sob a égide de médicos e engenheiros, a municipalidade ostentava o objetivo de racionalizar o espaço urbano para garantir boas condições de vida a toda população. Embora a universalização do saneamento básico e do esgoto, a mitigação de pestes e epidemias, a construção de espaços de lazer e a organização dos fluxos e das construções fossem intenções de indubitável nobreza, a prática não seguia o tom harmônico e pacifista da teoria.

Por detrás das vestes objetivas dos "melhoramentos" eram frequentemente perpetrados desejos escusos das elites. Assim, a implementação de obras viárias e de novos meios de transporte em São Paulo respondiam ao anseio de dinamização da acumulação de capitais, com o incremento do ritmo de circulação de mercadorias e da força de trabalho. Com os "embelezamentos" do Centro e das expansões a Oeste, procurava-se construir um espaço pleno para o desenrolar do cotidiano ambicionado pela alta sociedade, composto pelos negócios, a moradia, o consumo e as reuniões sociais. Para além do que se erguia, havia muito o que retirar. Movidas pelo temor da pobreza e suas supostas moléstias, bem como pelos desconfortos promovidos pelo choque de sua cultura refinada com o modo de vida dos trabalhadores, as elites arranjaram motivo para expulsar de perto os pobres - desterro também impulsionado pelos interesses imobiliários, que se expandiam loucamente com o crescimento urbano, seguido pelas também prósperas atividades urbanizadoras ${ }^{8}$.

\footnotetext{
${ }^{8}$ Com atividades urbanizadoras, refiro-me aos mercados oriundos da instalação de infraestruturas, fabricação e comércio de materiais para a construção civil, empreitadas, loteamentos, etc.
} 
Contudo, apesar das contundentes forças empregadas em sua realização, tais planos não transcorreram da forma lisa e plena como projetavam seus arautos. Foram entravados e atravancados por desejos e interesses dos mais diversos setores da população. Grandes episódios explicitam os mais vultuosos conflitos, como o levante popular conhecido como A Revolta da Vacina (1903) e as grandes mobilizações operárias das décadas de 1910 e 1920, com ápice na grande greve geral de 1917. A cidade que queriam plena era irrequieta, pulsante. Se a queriam equilibrada e pacífica, seu dia a dia era um constante agenciamento de conflitos, pois a desconcertante coexistência dos contrários era congênita ao "fazer-se" da cidade moderna".

Em nossa passagem por São Paulo, contudo, não veremos eventos dessa magnitude. Sequer transitaremos pela cidade inteira. Mas em nossas idas e vindas pela Avenida Angélica, uma via central para os desejos urbanos do Estado e da alta sociedade, acompanharemos as dinâmicas coloquiais dessas mesmas tensões e de outras mais, somente visíveis através do olhar detido às pequenas, contudo não menos agitadas, movimentações do cotidiano.

Um olhar imbuído pela proposta de Bernard Lepetit, e de tantos outros ${ }^{10}$, de tomar os agentes sociais como protagonistas do processo histórico, em contraste às interpretações que tendem a apreender suas ações apenas como reflexos de esquemas explicativos pré-estabelecidos. Em nossa trajetória, procuramos justamente tensionar e problematizar esses esquemas à medida que nos aproximamos das multifacetadas

\footnotetext{
${ }^{9}$ Tomo a ideia de um "fazer-se" da cidade das reflexões de Josianne Cerasoli, que a utiliza para expressar um processo no qual os habitantes da cidade não a viram transformar-se "como uma alvorada", mas foram presentes e ativos em seu próprio "fazer-se". Cf. CERASOLI, 2014, p. 15.

${ }^{10}$ Aqui faço referência não apenas às reflexões de Bernard Lepetit em seu texto $A$ história leva os atores a sério?, mas também às tantas pesquisas realizadas em solo nacional que procuram pensar os atores sociais como protagonistas do processo histórico, como DIAS, Maria Odila Leite da Silva. Quotidiano e poder em São Paulo no séc. XIX. São Paulo: Brasiliense, 1984; MARINS, Paulo César Garcez. Através da rótula: sociedade e arquitetura no Brasil, séculos XVII a XX. Tese (Doutorado em História Social) - FFLCH, Universidade de São Paulo, São Paulo, 1999; OLIVEIRA, Maria Luisa Ferreira de. Entre a casa e o armazém. Relações sociais e experiência de urbanização: São Paulo, 1850-1900. São Paulo: Ed. Alameda, 2005; CHALHOUB, Sidney. Trabalho, lar e botequim: o cotidiano dos trabalhadores no Rio de Janeiro da belle époque. Campinas: Ed. Unicamp, 2008; BORIN, Monique Félix. Barra Funda e o fazer da cidade: experiências da urbanização em São Paulo (1890-1920). Dissertação (Mestrado) - FFLCH-USP, 2014; entre tantos outros. Para o referido texto de Lepetit, cf. LEPETIT, Bernard. A história leva os atores a sério? In: LEPETIT, Bernard; SALGUEIRO, Heliana Angotti (org.). Por uma nova história urbana. São Paulo: Edusp, 1996, p. 227-244.
} 
tramas cotidianas desses atores. Nosso intento foi procurar nos comportamentos e casos particulares os traços de regularidade característicos do geral e do coletivo, de maneira a não apenas contestar antigos consensos, mas também estabelecer novos entendimentos para esse intrincado e plurifacetado processo.

Nesse sentido, não se trata de eliminar ou ignorar, por exemplo, a importância das elites e do Estado na constelação de processos decisórios que conformaram a cidade, mas antes de mostrar que esses, junto aos agentes imobiliários, não formavam um conjunto coeso e orquestrado. Pelo contrário, eram constituídos por uma série de indivíduos e grupos cujos interesses, públicos e privados, oscilavam entre o consenso, a indiferença e a divergência. Não havia um projeto monolítico para a cidade, mas vários, que eram constantemente disputados, negociados e tensionados. E não apenas entre os poderosos - que, apesar de veementes e arrogantes, estavam longe de exercer uma onipotência soberana -, mas também entre os variados grupos de média e baixa renda, ativos e operantes nos debates e embates da cidade, e que, através de seus próprios meios e estratégias, concorriam com seus interesses pelo contínuo "fazer-se" de São Paulo.

Em suma, eis o objetivo deste trabalho: deslindar consensos e firmar novas interpretações para o "fazer-se" da cidade ao trazer à tona dinâmicas, relações, estratégias, confluências e disputas articuladas pela ampla gama de agentes envolvidos nesse processo. Não à toa escolhemos a Avenida Angélica, das décadas de 1890 a 1920, como objeto $^{11}$. Sobre ela incide na historiografia uma imagem monolítica, que reitera a

\footnotetext{
${ }^{11}$ A baliza temporal inicial foi estabelecida pelo loteamento do Boulevard Burchard, do qual fazia parte a Rua Itatiaia, princípio da Avenida Angélica. Já o marco final foi posicionado na década de 1920 pois, a partir desta, a vida na cidade começa a passar por mudanças profundas em seus aspectos materiais, demográficos, cotidianos, sociais e, sobretudo, culturais. Nesse universo cultural estreante, que passa a ter como centro irradiador os Estados Unidos, contrastando com o enaltecimento da família, do intelecto, da virtude e da ancianidade arraigados pela cultura burguesa da Europa oitocentista, emergem como valores centrais o indivíduo, o dinamismo corporal e mental, a impetuosidade, a virilidade e a jovialidade. Daí, ocorrem grandes transformações nos valores que moldam o agir dos indivíduos, bem como a produção e uso de suas materialidades, que no caso da cidade passam a ser cada vez mais moldadas pela verticalização e pelo transporte automotivo. Nesse universo, mesmo práticas antigas ganham novos sentidos e significados. Sem contar que, a partir da década de 1920, com o ingresso de novos agentes imobiliários na cidade, as dinâmicas de conformação dos territórios também terão seu quadro radicalmente transformado. O caso mais emblemático dessa mudança é a entrada definitiva e arrebatadora da Cia City nos negócios de loteamento, emplacando um novo ideário para os bairros exclusivos, não mais pautados nos faubourgs parisienses, mas nos subúrbios ingleses e norte-americanos, influenciados pelo ideário das
} 
explicação da modernização de São Paulo como a vitória plena e triunfante de um projeto consensual das elites ${ }^{12}$. Sendo assim, trata-se de um palco privilegiado para observarmos as tensões, fissuras e incongruências ocultadas por essa homogeneidade construída. Afinal, ao darmos início a nossa incursão na Avenida Angélica, rapidamente veremos que seu "fazer-se" diferia em muito do exclusivismo pacífico, elitizado e ordeiro apresentado pela bibliografia. Ali, lado a lado com os anseios exibitivos e segregativos das elites e do Estado, habitavam as ruas, desenvolviam suas vidas e erguiam suas residências os mais diversos membros dos setores médios e trabalhadores da cidade - loteadores, pequenos proprietários remediados, grandes proprietários abastados, profissionais liberais de maior ou menor prestígio, operários, construtores, famílias abastadas, remediadas e pobres, costureiras, criados, funcionários públicos de todos os escalões e trabalhadores manuais de toda a ordem. Longe de ser plena, a Angélica era uma encruzilhada, onde se encontravam os desejos, estratégias e práticas da ampla e variada gama de seus habitantes. Encontros que por

garden cities. Para cultura dominante do Oitocentos Europeu e brasileiro, Cf. VALENCIANO, Jésus Cruz. El surgimiento de la cultura burguesa. personas, hogares y ciudades en la españa del siglo XIX. Madrid: Siglo XXI, 2014; PROST, Antoine. A família e o indivíduo. In: PROST, Antoine e VINCENT, Gérard, op. cit., p. 61-115; PROST, Antoine. O trabalho. In: PROST, Antoine e VINCENT, Gérard. História da Vida Privada: da Primeira Guerra aos nossos dias. São Paulo: Companhia das Letras, 1992, vol. 5, p. 21-61 e CARVALHO, Vania Carneiro de. Gênero e Artefato: o sistema doméstico na perspectiva da cultura material - São Paulo 1870-1920. São Paulo: Edusp, 2008, p. 23-89. Para cultura emergente a partir da década de 1920, cf. SEVCENKO, 1992, p. 23-89. Para transformações nas relações imobiliárias, cf. RIBEIRO, Luiz Cesar de Queiroz. Dos cortiços aos condomínios fechados. Rio de Janeiro: Civilização Brasileira, 1997. Para bairros, jardins e verticalização, cf. CAMPOS NETO, 2000, p. 240-246 e MARINS, Paulo César Garcez. Habitação e vizinhança: limites da privacidade no surgimento das metrópoles brasileiras. In: NOVAIS, Fernando e SEVCENKO, Nicolau (org.). História da vida privada no Brasil República: da Belle Époque à era do rádio. São Paulo: Companhia das Letras, 2006, p. 170-215.

${ }_{12}$ Aqui me refiro, principalmente, aos trabalhos de HOMEM, Maria Cecília Naclério. Higienópolis: grandeza e decadência de um bairro paulistano. São Paulo: PMSP, 1980; ROLNIK, Raquel. A cidade e a lei. São Paulo: Studio Nobel, 1997; MARINS, Paulo César Garcez. Habitação e vizinhança: limites da privacidade no surgimento das metrópoles brasileiras. In: NOVAIS, Fernando e SEVCENKO, Nicolau (org.). História da vida privada no Brasil - República: da Belle Époque à era do rádio. São Paulo: Companhia das Letras, 2006, p. 170-187; GROSTEIN, Marta Dora. A cidade clandestina: os ritos e os mitos. São Paulo: Faculdade de Arquitetura e Urbanismo da Universidade de São Paulo (Tese de Doutorado), 1987; SEGAWA, Hugo. Prelúdio da Metrópole: arquitetura e urbanismo em São Paulo na passagem do século XIX ao XX. São Paulo: Ateliê Editorial, 2000; TOLEDO, Benedito Lima de. São Paulo, três cidades em um século. São Paulo: Cosac Naify, 2004; MOBEIG, Pierre. La croissance de la ville de São Paulo (1953). In: Revue de Geographie Alpine, 1953; MORSE, Richard. De comunidade a metrópole: biografia de São Paulo. São Paulo: Comissão do IV Centenário de São Paulo, 1954; PRADO JR. Caio. Nova contribuição para o estudo geográfico da cidade de São Paulo. Estudos Brasileiros, ano III, vol. 7, no 19-21, Rio de Janeiro, 1941. 
vezes resultavam em conflitos, tensões, desarranjos e atritos, mas, surpreendentemente, também ocasionavam inusitados acordos e convergências. Um "fazer-se" irrequieto e movediço, estranho às explicações unívocas, retilíneas e monocromáticas, e mais próximo de leituras mais recentes, que interpretam a modernização da cidade como um processo ambivalente, plural, tenso e imbricado ${ }^{13}$.

Essas ações e relações se desenrolavam em três esferas sobrepostas da Avenida, coincidentes com as dimensões do urbano estabelecidas por Ulpiano Bezerra de Meneses: o artefato, a representação e o campo de interações e disputas sociais ${ }^{14}$. Assim, veremos que os encontros e desencontros que conformaram a Angélica transcorriam e se entrecruzavam no universo da materialidade do espaço abrangendo desde sua localização na cidade até as diversas práticas construtivas que paulatinamente foram dando forma à sua paisagem -, no campo das disputas por sua representação e apropriação de seu poder simbólico e, por fim, pelas articulações e desarticulações dos diferentes modos de vida que eram justapostos na rua, nas casas, na praça e em outros espaços da cidade.

Podemos organizar os atores envolvidos no "fazer-se" da Angélica em cinco grupos: os agentes imobiliários, a municipalidade e as três classes nas quais ordenamos os que habitavam sua extensão - as elites, os setores médios e os trabalhadores. Suas interações, confluentes ou conflituosas, transcorriam em três eixos entrecruzados. A começar pelo interesse econômico de pequenos e grandes proprietários da região que desejavam lucrar com a venda de imóveis e terras na Avenida. Para tanto, elaboraram estratégias variadas e circunstanciais. Variadas, pois, como veremos, alguns tiveram

\footnotetext{
${ }^{13}$ Refiro-me principalmente à perspectiva adotada por trabalhos como os de CHALHOUB, 2008; BORIN, 2014; CERASOLI, 2014; MARINS, Paulo Cesar Garcez. La avenida Paulista de la Belle Époque: elites en disputa. In: GORELIK, Adrián e PEIXOTO, Fernanda Arêas (org.). Ciudades latino-americanas como arenas culturales. Buenos Aires: Siglo XXI, 2016; MARINS, Paulo César Garcez. Um lugar para as elites: os Campos Elíseos de Glette e Nothmann no imaginário urbano de São Paulo. IN: LANNA, A. et al (org.). São Paulo, os estrangeiros e a construção das cidades. São Paulo: Ed. Alameda, 2011; e TERRA, Paulo Cruz. Conflitos cotidianos e motins: os usuários de bondes no Rio de Janeiro no final do século XIX e início do XX. História Social, n. 22 e 23, Campinas, 2012, entre outros.

${ }^{14}$ Cf. MENEZES, Ulpiano Toledo Bezerra de. Morfologia das cidades brasileiras: introdução ao estudo histórico da iconografia urbana. Revista USP, São Paulo, n. 30, jun-ago, 1996, p. 145-55 e MENEZES, Ulpiano Toledo Bezerra de. A cidade como bem cultural: áreas envoltórias e outros dilemas, equívocos e alcance da preservação do patrimônio ambiental urbano. In: Vitor Hugo Mori et al (Orgs.). Patrimônio: Atualizando o Debate. São Paulo: 9a SR/ IPHAN, 2006.
} 
interesse em comercializar a Avenida como uma mercadoria exclusiva e elitizada, com menor público consumidor, porém com maior preço de venda por unidade. Outros adotaram estratégia oposta, procurando vender terras e casas para grupos de média e baixa renda, com menor preço, porém com mercado mais abrangente, tática primordial, por exemplo, dos pequenos proprietários. Contudo, entre os abastados, as adesões eram variadas, e por vezes circunstanciais. Alguns optavam por vender propriedades a seus semelhantes - como Maria Angélica de Souza Queiroz - outros para os diferentes - como Domingos Jaguaribe. Posturas que não eram absolutas, mas variantes de acordo com as possibilidades observadas pelos agentes nos diferentes cenários do mercado imobiliário, como veremos no caso paradigmático de Martin Burchard e Victor Nothmann, que em menos de uma década adotaram alternadamente ambas as estratégias.

O segundo eixo de relações dava-se em âmbito simbólico. Como já vimos, o interesse da municipalidade e do Estado alinhava-se aos anseios de manutenção das relações da economia cafeeira com o mercado internacional. Nesse sentido, ansiavam a Angélica como mais um de seus cartões-postais, utilizados como artifícios para a promoção do otimismo e da confiança nos corações e mentes dos agentes econômicos e estatais do mundo setentrional. Parte das elites e dos setores médios confluiu nesse projeto, apropriando-se desse espetáculo material para suas estratégias próprias de comercialização imobiliária, representação e inserção social/profissional. Apropriações que, apesar de congêneres, não deixavam de guardar tensões e atritos.

Esses conflitos eram acentuados pelos interesses imobiliários de alguns espectros dessas mesmas classes, que, como vimos há pouco, caminhavam em sentido contrário a esse projeto exclusivista de "embelezamento". Isso sem falar dos trabalhadores que ali habitavam, cujas materialidades e modos de vida eram incompatíveis com esse cenário idealizado e que para a rua ansiavam suas próprias representações e significados.

Terceiro feixe: a confrontação das espacialidades inerentes aos desejos e práticas dispostas nos habitus das diferentes classes que compunham o cotidiano da Avenida. Para melhor compreender essa esfera, façamos uma breve incursão teórica na 
sociologia de Pierre Bourdieu, parte fundamental do alicerce que deu sustento não somente a este eixo, mas, de maneira mais ou menos explícita, a grande parte das reflexões desenvolvidas neste trabalho.

Para Bourdieu, o habitus é modulado de acordo com as possibilidades e limites disponíveis para cada indivíduo na sociedade, ou seja, por sua posição relacional na escala social, econômica e política determinada pela hierarquização dos campos e das classes. O habitus de cada classe é constituído por três dimensões - ethos, eidos e hexis -, responsáveis por conformar a percepção, a valorização e o juízo do mundo pelos indivíduos, estabelecendo as diretrizes para o seu agir cotidiano ${ }^{15}$. Embora raramente separaremos as três partes componentes do habitus em nossa análise, esclarecer os sentidos particulares de cada uma ajuda a compreender as instâncias de funcionamento da construção dos princípios que regem a ação dos indivíduos. O ethos é o conjunto de disposições que formam a moral cotidiana. São os predicados que estabelecem valores e juízos sobre o mundo e que guiam, de maneira não consciente, as ações corriqueiras. O eidos é a apreensão intelectual da realidade, é a conformação das representações que, além de sustentarem o ethos, também funcionam como guias para as tomadas de decisão cotidianas que perpassam o esforço da meditação, como a formação de juízos racionais, ponderações éticas e a elaboração de estratégias calculadas. Por fim, a hexis constitui os princípios interiorizados pelo próprio corpo: as posturas, expressões corporais e os mecanismos de satisfação e de gerenciamento do desejo.

O habitus é a "segunda natureza", conformada através do contato dos indivíduos com seu meio material, social e institucional. Ele estabelece limites e possibilidades para a ação, tendendo a direcionar os indivíduos para os atos que reforcem seus princípios e crenças, e afastá-los do que os contraria ou critica. Se tomado com

\footnotetext{
15 Todas as formulações sobre o conceito de habitus a seguir foram baseadas nas reflexões contidas nos seguintes trabalhos: BOURDIEU, Pierre. Estrutura, habitus e prática. In: BOURDIEU, Pierre; MICELLI, Sergio (org.). A economia das trocas simbólicas. São Paulo: Ed. Perspectiva, 2007, p. 337-361; BOURDIEU, Pierre. Condição de classe e posição de classe. In: op. cit., p. 3-27; BOURDIEU, Pierre. Campo do poder, campo intelectual e habitus de classe. In: op. cit., p. 183-203; THIRY-CHERQUES, Hermano Roberto. Pierre Bourdieu: teoria na prática. Revista de Administração Pública, EBAPE-FGV, Rio de Janeiro, jan./fev. 2006, p. 33; PETERS, Gabriel Moura. Configurações e reconfigurações na teoria do habitus: um percurso. XIV Congresso Brasileiro de Sociologia. Anais: Rio de Janeiro, 2009.
} 
demasiada rigidez, pode ser confundido como uma espécie de determinismo, no qual os indivíduos seriam inertes às condições pré-estabelecidas pelo meio social - amigos, colegas de trabalho, vizinhos - e pelas instituições - família, casamento, educação formal, Estado, religião, empresas. Contudo, na esteira de Loïc Wacquant, nos parece mais pertinente conceber que, apesar de extremamente eficiente e robusto, o habitus não é um todo inexorável, mas pode ter suas proposições “erodidas, contidas ou até desmanteladas pela exposição a novas forças externas" ${ }^{\prime 16}$. O sociólogo francês cita, por exemplo, o caso extremo das imigrações. Diante de um novo meio, muitos indivíduos são impelidos a alterar completamente os seus habitus para suprir suas necessidades afetivas e socioeconômicas. Mas uma pessoa pode ser um estrangeiro em seu dia a dia ao adentrar um novo meio social, deparar-se com novos indivíduos, novas ideias, novas organizações materiais, entre outra série de possibilidades. A própria trajetória de Bourdieu, em sua célebre autoanálise, exemplifica isso ${ }^{17}$.

Assim, podemos conceber o habitus como uma estrutura aberta, pois apesar de carregar as bagagens do aprendizado passado, demanda constante atualização de suas disposições perante o mundo ${ }^{18}$. Isso significa que é falso pensar os indivíduos como meros reprodutores das normas sociais. O sofrimento, o desconforto e o deslocamento que perpassam a inculcação e a obediência das disposições dos habitus são corriqueiros. A ação subjetiva não é mecânica, mas uma constante e tensa negociação do corpo individual com o mundo social. Algo extremamente semelhante à descrição freudiana da vida interior como um constante agenciamento de conflitos, deflagrados principalmente pelos embates entre os desejos do indivíduo e seus obstáculos culturais, sociais e materiais no mundo ${ }^{19}$. Apesar dessa comparação aparentar heterodoxa, é patente que o próprio Bourdieu procurou aproximar suas teorias da

\footnotetext{
${ }^{16}$ Loïc Wacquant (2004a, p. 2) apud PETERS, op. cit., p. 15.

${ }^{17}$ BOURDIEU, Pierre. Esboço de uma autoanálise. São Paulo: Companhia das Letras, 2005.

18 PONTES, Nicole Louise Madero Teles de. Habitus e libido social: revisando Bourdieu através da psicanálise. Estudos de Sociologia - Revista do Programa de Pós-Graduação em Sociologia da UFPE, vol. 2, n. 17, 2011 (versão digital).

19 SAFATLE, Vladimir. Aquele que diz "não": sobre um modo peculiar de falar de si. In: FREUD, Sigmund. A negação. São Paulo: Cosac Naify, 2014, p. 36.
} 
psicanálise em seus últimos textos, assim como outros comentadores de sua obra ${ }^{20}$. Aqui, longe de querer comprovar a possibilidade e o rendimento da articulação dessas duas teorias, um intento para o futuro, a menção a Freud serve mais como um recurso analógico e uma potente imagem explicativa para a abordagem que faremos dos comportamentos individuais.

Dadas as diferentes posições sociais que ocupavam as elites, os abastados e os trabalhadores, não é difícil imaginar o diferente espectro de possibilidades e limites que formatavam seus habitus. Noutras palavras: as práticas cotidianas desses grupos eram fundadas e articuladas por moralidades, visões de mundo, estratégias práticas e comportamento corporal que implicavam em díspares construções e apropriações do espaço e do tempo da Avenida. Sob essa ótica veremos que, ao invés de una, a espacialidade da Angélica era composta por três universos - formados por ruas, casas, praça e serviços - concomitantes, por vezes harmonicamente entrelaçados, por outras em tensão divergente. Microcosmos articulados por fronteiras materiais e sociais, de porosa consistência, através dos quais eram mediados, tensionados e negociados os interesses e práticas de seus grupos congênitos.

Por fim, embora de maneira menos profunda, destacamos um último aspecto ligado às tramas cotidianas da cidade: a vivência da modernidade. Através dos imbricados eventos que circundavam duas de suas emblemáticas máquinas, o bonde elétrico e o automóvel, procuramos entrever como conviviam socialmente e, por vezes, nos corações e mentes dos próprios indivíduos, diversos horizontes de expectativa e experiência sobre a modernização de São Paulo. Observaremos que, assim como as relações no "fazer-se" da cidade, as relações entre humanos e máquinas eram vivenciadas e representadas como ambivalentes, polêmicas, contraditas e divergentes.

O diálogo entre a natureza restrita de nosso objeto - uma Avenida - e os amplos propósitos de nossa investigação - penetrar na entremeada trama de relações sociomateriais implicadas no "fazer-se" da cidade - nos levaram a uma relação bastante peculiar com as fontes documentais. A começar pela abrangência do corpus documental, composto por registros cartográficos, jornais e revistas, pedidos de obras

\footnotetext{
${ }^{20}$ Tais relações foram detidamente perscrutadas por PONTES, op. cit.
} 
privadas, Atas da Câmara Municipal, processos de leis municipais e iconografias. Essa amplitude é resultante do anseio constante em articular três dimensões da cidade comumente estudadas em separado na historiografia - seu âmbito material e econômico, as tensões sociais envolvidas em sua elaboração e vivência cotidiana e a construção de seus significados e representações. Sendo assim, nosso desafio constituiu em colocar as fontes em constante diálogo, de maneira que nossas explicações pudessem transcender alguns achatamentos frequentes: a cidade como pano de fundo, tomada como mera paisagem do social, quando ignoradas as potências e limites de sua materialidade; a modernização como um processo apaziguado, quando ignorados seus conflitos inerentes; o "fazer-se" como um processo hegemônico das elites, quando insondadas as plurais estratégias empregadas pelas outras classes; e a frequente autonomização do estudo das representações da cidade, sem levar em conta suas intrínsecas relações com as dimensões vividas dos conflitos econômicos, políticos e sociais ${ }^{21}$.

Daí a importância de observar simultaneamente muitas tipologias, pois em cada uma encontramos diferentes aspectos e faces dos eventos e processos que compuseram o "fazer-se" da Avenida Angélica. Seu paciente e minucioso cotejo nos abriu universos de possibilidades indisponíveis nas análises isoladas. Devemos observar que penetrar profundamente em tramas tão estreitas seria um trabalho homérico não fosse o recorte preciso de nosso objeto. Nesse sentido, confluímos com Lepetit quando afirma que todas as escalas de trabalho possuem possibilidades e problemas únicos, impossíveis nas miradas de outra grandeza. Não à toa o historiador advoga pelo esforço de articulação entre as escalas, de maneira que explicações e informações obtidas em diferentes patamares possam dialogar e assim tornar mais ricas e complexas as

\footnotetext{
21 Tal "desafio" adveio das perspectivas críticas elaboradas por Cf. CARPINTERIO, Marisa Varanda Teixeira e CERASOLI, Josianne Francia. A cidade como história. História: Questões \& Debates, Curitiba, n. 50, jan./jun. 2009. Editora UFPR, p. 93-94 e BORIN, Monique. Acervos históricos e estudos da urbanização: cruzamentos de fontes urbanísticas e judiciárias como recurso metodológico. IV Encontro da Associação Nacional de Pesquisa e Pós-Graduação em Arquitetura e Urbanismo. Anais: Porto Alegre, 2016 (versão digital). Disponível em: http://www.anparq.org.br/dvd-enanparq-4/SESSAO\%2042/S42-01BORIN,\%20M.pdf (último acesso em fevereiro de 2017).
} 
interpretações sobre a cidade ${ }^{22}$. Assim, fazer a história de uma rua ou de um bairro deve ser mais do que reproduzir em pequena escala as explicações estabelecidas em âmbito médio ou macro ou pensar em uma história autônoma, alheia ao resto da cidade. Pelo contrário, deve ser um laboratório, um âmbito de novas descobertas através das quais poderão ser problematizadas e tensionadas as explicações prévias, formando novas interpretações, que serão posteriormente averiguadas por estudos em outras escalas, e assim por diante. Por isso propomos não uma história da Avenida, cerceando seus significados a um microuniverso da cidade, mas através da Avenida, de maneira que esses resultados possam dialogar e debater na ampla arena dos estudos que lidam com o "fazer-se" da cidade.

Antes de finalizarmos esta introdução, passemos brevemente pelas fontes utilizadas neste trabalho, para que o leitor possa apreender de maneira mais palpável o que até aqui foi disposto abstratamente. Façamos de tal maneira que, paralelamente, também possamos transitar por um breve mapa de como organizamos a apresentação deste trabalho.

Iniciaremos o primeiro capítulo percorrendo, através das propagandas veiculadas para o Boulevard Burchard, os anseios que motivaram loteadores e elites a idealizar espaços exclusivos como o pretendido na Avenida Angélica. Contudo, veremos que representações e ideias, embora potentes, não são suficientes para criar um espaço. Pelos pedidos de obras para a via, através dos quais pudemos realizar uma espacialização cronológica da ocupação da Avenida, notaremos que desde o princípio seus habitantes primordiais foram trabalhadores de poucas posses ${ }^{23}$. Em busca de

22 LEPETIT, Bernard. Arquitetura, Geografia, História: usos da escala. In: LEPETIT, Bernard; SALGUEIRO, Heliana Angotti (org.). Por uma nova história urbana. São Paulo: Edusp, 1996, p. 191-226.

${ }^{23}$ Os pedidos de obra foram consultados no Fundo de Obras Privadas do Arquivo Histórico Municipal de São Paulo. À época de nosso período de pesquisa, a realização de um pedido de licença para construção acompanhado de uma planta da edificação eram normas da municipalidade. Certamente, como todas as regras, houve muitos que as descumpriram, mas ao que vemos esses desvios não possuíam nenhuma especificidade de social, pois há abundância de pedidos de todas as classes sociais no acervo. Sendo assim, ao analisar esse conjunto de documentos, não corremos o risco de estarmos sujeitos a informações produzidas somente por grupos específicos, o que poderia nos conduzir a interpretações errôneas quanto à ocupação da Avenida. Pelo contrário, nos deparamos com um universo amplo e heterogêneo. $\mathrm{O}$ conteúdo dos pedidos foi abordado tanto pelo viés discursivo como pelo indiciário. No primeiro caso, através dos desenhos procuramos apreender os discursos que estavam sendo propagados pelas opções estilísticas e compositivas das residências e, por vezes, quais eram as intenções subjacentes à contratação 
explicações para essa inusitada discrepância, aprofundaremos nossa mirada para os pedidos de obras, vendo-os não apenas como indícios de uma ocupação, mas também como manifestação de estratégias econômicas. Assim, descobriremos a pujante presença dos pequenos proprietários, responsáveis pela construção de esparsos e exíguos conjuntos geminados, totalmente alheios aos ideais projetados pelos loteadores e pelas elites. Mas como poderiam ter agido de maneira tão eficiente e marginal, se os atores opostos eram muitos mais poderosos?

Daí, acederemos a uma das principais constatações de nosso trabalho: seus muros de controle e segregação eram altos, mas estavam longe de ser íntegros e impenetráveis. Acompanharemos já nos primeiros anos da Avenida um processo que marcou toda sua trajetória. Indivíduos e grupos poderosos possuíam ações contundentes, mas norteadas por comportamentos e associações errantes. Estavam sujeitos ao erro e ao acaso, bem como às ambivalências de seus próprios interesses. Sem falar nas oscilantes relações que mantinham, ora confluentes, ora conflituosas, ora harmônicas, ora divergentes.

As primeiras fissuras no projeto exclusivista da Avenida foram decorrentes da ambígua atuação de seus próprios loteadores, Victor Nothmann e Martin Burchard. Penetraremos nos irregulares anseios da dupla alsaciana comparando as propagandas com as Plantas da Cidade produzidas pela municipalidade em 1895, 1897 e 1905. Faremos isso seguindo as sugestões de Eliane Kuvasney e Lucia Noemia Simoni, que propõem abordá-las não apenas enquanto representações do espaço existente, mas também como projetos do porvir, inscritos nos mapas pelos próprios agentes privados $^{24}$.

\footnotetext{
de determinados profissionais. Pelo caminho do indício, os pedidos de obra nos auxiliaram a analisar quais classes sociais habitavam a Avenida, além de periodizar, especializar e quantificar os pedidos de cada grupo. Por fim, também nos auxiliaram na compreensão das trajetórias de indivíduos, tanto na definição de sua posição social, quanto em relação às transformações pelas quais eles passaram, marcadas, por exemplo, pela mudança de residência ou pela aquisição de novas propriedades.

${ }^{24}$ Cf. SIMONI, Lucia Noemia. A planta da cidade de São Paulo de 1897: uma cartografia da cidade existente ou da cidade futura? In: SIMPÓSIO LUSO-BRASILEIRO DE CARTOGRAFIA HISTÓRICA. Anais: Ouro Preto: UFMG, 2009 e KUVASNEY, Eliane. Os mapas como "operadores espaciais" na construção da cidade de São Paulo do início do século XX. Revista do Instituto de Estudos Brasileiros, Brasil, n. 64, p. 167-182, ago. 2016.
} 
Como reação a essa heterogeneidade, acompanharemos a inusitada epopeia de uma lei de recuos para a Avenida. Através das Atas da Câmara Municipal, pudemos observar o cabo de guerra entre os interesses simbólicos que circundavam a criação de um cartão-postal e a influência dos variados agentes imobiliários em ação na área, vislumbrados principalmente a partir dos pedidos de obra ${ }^{25}$.

Nesse mesmo cruzamento documental, passaremos ao segundo capítulo, no qual acompanharemos mais de perto as relações dos habitantes despossuídos da Avenida com a municipalidade. Associando as Atas e os pedidos de obras ao SARA-Brasil ${ }^{26}$, compreendemos a geografia das fronteiras socioeconômicas da Avenida ao longo do tempo, o que nos ajuda a explicar o errante percurso de sua pavimentação, bem como a predileção da municipalidade por determinados trechos em detrimento de outros. Nos processos de leis $^{27}$ e nos jornais ${ }^{28}$, veremos a população rebelar-se e acompanharemos as acirradas trajetórias de suas batalhas, muitas vezes perdidas, mas às vezes triunfantes. Novamente, o interesse simbólico do Estado emergirá em atrição: agora não com interesses econômicos, mas com as experiências cotidianas vividas com as "máquinas do progresso", os bondes e os carros. Essa disputa perpassava o âmbito concreto, mas também tangenciava os ambivalentes significados e expectativas que

\footnotetext{
${ }^{25}$ As Atas da Câmara Municipal foram consultadas através do Centro de Memória da Câmara Municipal de São Paulo, disponível no site: http://www.camara.sp.gov.br/memoria/atas-e-anais-da-camaramunicipal-2/ (último acesso em fevereiro de 2017).

${ }^{26}$ Apesar do SARA-Brasil também conter intenções em sua produção, essas passam ao largo de nossos interesses, uma vez que estavam enfocadas na intenção da municipalidade em estabelecer um instrumento de planejamento e controle fiscal. Sendo assim, o intuito de analisá-lo é exclusivamente apreender relações materiais do bairro, como tamanhos e distâncias de lotes, volumes edificados, etc. MENDES, Ricardo. S.A.R.A. Brasil: restituindo o Mapa Topográfico do Município de São Paulo. Informativo do Arquivo Histórico de São Paulo. São Paulo, Ano 10, no 37, dez. 2014.

${ }^{27}$ Os processos de leis foram consultados no Fundo da Prefeitura do Arquivo Histórico Municipal de São Paulo.

${ }^{28}$ Os jornais foram consultados através da Hemeroteca Digital da Biblioteca Nacional, disponível em: http://bndigital.bn.gov.br/hemeroteca-digital (último acesso em fevereiro de 2017). Os diários foram analisados de duas formas, por vezes enquanto discursos específicos sobre a cidade e a sociedade, por outros como portadores de informações e indícios materiais e sociais, como a profissão de um indivíduo ou o seu endereço. Os diários analisados foram, salvo exceções: O Estado de São Paulo, A Gazeta, O Combate e $O$ Correio Paulistano. Para as análises discursivas utilizamos como guia crítico bibliografia específica a respeito de cada diário, referenciados quando necessário. Por fim, vale ressaltar o auxílio constante que nos prestou o trabalho de Tania de Luca para a penetração crítica nos meandros desses complexos documentos. LUCA, Tania Regina de. História dos, nos e por meio dos periódicos. In: PINSKY, Carla Bassanezi (Org.). Fontes históricas. São Paulo: Contexto, 2005. p. 111-153.
} 
habitavam os corações e mentes que vivenciaram a modernização da cidade. Seus sinuosos caminhos, acompanharemos através dos jornais, analisados aqui predominantemente em seu registro discursivo. E em suas veredas, perceberemos que mais do que tensa, disputada e plural, a modernização carregava em si o indelével gene da contradição e da ambivalência. A força desse aspecto ficará patente ao observamos o misto de horror, maravilha, liberdade e turbulência que perpassava a experiência dos automóveis e dos bondes. Uma experiência que, como veremos, estará presente também em tantos outros âmbitos desse sinuoso e errante "fazer-se".

Quando mirados a partir de seus aspectos fragmentários e indiciários, associados com a análise detida nos desenhos contidos nos pedidos de obra, abrimos as portas para traçar as trajetórias sociomateriais de indivíduos e grupos das mais variadas classes sociais que habitavam a Avenida. Foi ao redor desses esboços biográficos que desenvolvemos os últimos três capítulos, dedicados à análise das relações do habitus de cada classe com os significados e usos dos espaços da via. Por meio dessas trajetórias individuais, mas observadas a partir de seus aspectos coletivos, procuraremos apreender os sentidos que os membros de cada classe atribuíam às espacialidades da casa e da rua e como construíam e mobilizavam essas materialidades como meios para consolidar seus modos de vida, inculcar e reproduzir costumes, elaborar estratégias de inserção e representação e desenvolver tantas outras práticas e relações que conformavam a vida de todo dia. Em meio a essa pulsante trama, penetraremos em outra dimensão de tensões sociais, agora entre as próprias classes, travadas em seus corpos, desejos e práticas do dia a dia. Novamente, voltaremos à metáfora do muro, e veremos que as fronteiras sociais e materiais da Avenida eram de ambígua consistência. Atentos às suas mais sutis mobilizações, veremos que os modos de vida nos extremos da escala social, para além de conflitantes, eram muitas vezes complementares, senão inerentes.

Agora, com o mapa completo em mãos, vamos à cidade. 
$* * *$ 



\section{Sinuosos interesses, intrincadas materialidades}





\section{Retornar ao Éden: um loteamento exclusivo}

A trajetória da Avenida Angélica tem seu início entrelaçado com a movimentação de seus idealizadores, os alsacianos Victor Nothmann e Martinho Burchard ${ }^{1}$. Nothmann iniciou suas atividades na cidade na década de 1870 como mascate. Como muitos outros capitalistas, com a insegurança provocada pela quebra do Banco Mauá, em 1875, e o grande deslocamento de capitais para o mercado de terras e imóveis da capital, embarca no efervescente mercado imobiliário ${ }^{2}$. Ao final do decênio, firma parceria com Frederico Glette no loteamento dos Campos Elíseos, projetado como um bairro exclusivo para as elites ${ }^{3}$. O empreendimento lhe proporcionou grandes rendimentos que, na década seguinte, somaram-se à sua destacada posição como atacadista de tecidos, levando-o por diversas vezes ao posto de cônsul do Império Alemão em São Paulo .

\footnotetext{
${ }^{1}$ FALBEL, Anat e OHNO, Celso Eduardo. CBI-Esplanada, memória e futuro de um edifício moderno em ${ }^{2}$ HOMEM, Maria Cecília Naclério. Higienópolis: grandeza e decadência de um bairro paulistano. São Paulo: PMSP, 1980, p. 60.

${ }^{3}$ MARINS, Paulo César Garcez. Um lugar para as elites: os Campos Elíseos de Glette e Nothmann no imaginário urbano de São Paulo. IN: LANNA, A. et al (org.). São Paulo, os estrangeiros e a construção das cidades. São Paulo: Ed. Alameda, 2011, p. 214-217.

${ }^{4}$ SIRIANI, Silva Cristina Lambert. Uma São Paulo alemã: vida quotidiana dos imigrantes germânicos na região da capital (1827-1889). São Paulo: Arquivo do Estado; Imprensa Oficial, 2003, p. 143-144 apud MARINS, op. cit., p. 216.
} 
Em 1890, aproveitou a abrupta dilatação de crédito propiciada pelo Encilhamento para ampliar seus negócios ${ }^{5}$. Beneficiou-se do vultuoso crescimento urbano, participando de catorze sociedades anônimas ligadas à atividade urbanizadora, bem como de quatro companhias dedicadas à instalação de infraestrutura e de três empresas ligadas a serviços e indústrias.

Nessas sociedades, além de obter rendimentos, Nothmann pôde estabelecer ampla rede de contatos com afortunados dos meios políticos e comerciais. Compartilhou títulos com: Domingos Sertório, presidente da Câmara Municipal entre 1887-1900, na Cia. Mercantil e de Obras Públicas Paulista; Pedro Vicente de Azevedo, presidente da Câmara entre 1892 e 1894, na Cia. São Paulo Territorial; Antônio Proost Rodovalho, que à altura já havia sido vereador durante sete legislaturas, tornando-se presidente da Câmara Municipal entre 1897 e 1899, na Cia. Paulista de Cortume e Fabricação de Calçados, na Cia. Rodovalho e na Cia. Ítalo-Paulista; Antônio Vicente de Sousa Queiroz, filho do Barão de Limeira, na Cia. Comercial Paulista; o banqueiro Numa de Oliveira, na São Paulo Territorial; e, por fim, membros das elites acadêmicas e artísticas, como Jules Martin, na Cia. Paulista Viaduto do Chá, e Luis Pucci, na Cia. Ítalo-Paulista e na Cia. Vila Pinto Gonçalves, entre outros ${ }^{6}$.

Dentre seus diversos rendimentos econômicos e sociais, essa teia de relações permitiu que Nothmann, juntamente com Burchard, realizasse na década de 1890 uma série de "melhoramentos" a encargo da municipalidade", bem como garantiu sua penetração dentro dos círculos abastados e oficiais da cidade que, como veremos,

\footnotetext{
${ }^{5}$ Para maior aprofundamento nas relações entre o Encilhamento e a disparada do mercado urbanizador, Cf. BRITO, Mônica Silveira. A participação da iniciativa privada na produção do espaço urbano: São Paulo, 1890-1911. Dissertação (Mestrado) - FFLCH-USP, São Paulo, 2000 e SIMONI, Lucia Noemia. O arruamento de terras e o processo de formação do espaço urbano no município de São Paulo, 1840-1930. Tese (Doutorado) - FAU-USP, São Paulo, 2002.

${ }^{6}$ BRITO, op. cit., p. $32-38$

${ }^{7}$ Obras que foram realizadas em terras de sua propriedade ou vizinhas às suas, mas que foram pagas pela municipalidade como "melhoramentos". Foram essas: o prolongamento e nivelamento da Rua Pacaembu em 1893, uma via que percorria o trajeto que hoje conhecemos como o da Avenida Higienópolis e da Rua Rio de Janeiro; e o prolongamento da Rua Itatiaia, hoje conhecida como Avenida Angélica, até a Rua das Palmeiras em 1896. Cf. Atas da Câmara da Cidade de São Paulo, 1893, v. 78 e Atas da Câmara da Cidade de São Paulo, 1893, v. 81.
} 
tiveram grande papel no empreendimento e na comercialização do Boulevard Burchard $^{8}$.

Ao que sabemos, Burchard teve trajetória semelhante à de seu companheiro. Chegado ao Brasil na década de 1870, firmou parceria comercial com Nothmann em 1879, dedicada tanto à venda de tecidos quanto à comercialização de terrenos ${ }^{9}$. Martinho teve registradas em seu nome terras na Móoca, nas proximidades da Estrada da Água Branca (atual bairro das Perdizes), Barra Funda, Brás e Consolação, algumas loteadas e comercializadas com a empresa Nothmann e Cia., outras autonomamente pela Burchard e Cia. Assim como Nothmann, com o pulular do Encilhamento, também se associou a algumas Sociedades Anônimas, como a Cia. Iniciadora Paulista e a Cia. Água e Luz do Estado de São Paulo ${ }^{10}$.

Em 1880, tornou-se cidadão brasileiro, e deu início a uma breve, porém expressiva, carreira política. Em 1885, foi à Hungria, representando sua nova pátria, em missão diplomática pelo Centro de Lavoura e Comércio ${ }^{11}$. No ano seguinte, participou ao lado de Antônio Proost Rodovalho e Antônio Aguiar de Barros ${ }^{12}$, o Conde de Itú, da comissão de receptiva ao imperador na capital. Em 1887, trouxe da Europa uma valiosa reprodução de uma relíquia descoberta nas ruínas de Pompeia, e ofereceu-a ao Museu Paulista, um gesto que suscitava potentes ganhos simbólicos ${ }^{13}$. Teve sua circulação nos meios abastados e poderosos da cidade acentuada ainda pelas profícuas relações de seu irmão Hermann, também parceiro na sociedade com Nothmann, e que na década de 1890 ocuparia o posto de vereador por três legislaturas ${ }^{14}$.

\footnotetext{
${ }^{8}$ Primeiro nome atribuído ao loteamento hoje conhecido como Higienópolis.

${ }^{9}$ O Correio Paulistano, São Paulo, 11 jan. 1879 e HOMEM, op. cit., p. 60.

${ }^{10} \mathrm{Cf}$. a sistematização de sociedades anônimas e seus associados na década de 1890 realizada por BRITO, op. cit. p. 16-24.

${ }^{11}$ Cf. Jornal da Tarde, São Paulo, 17 nov. 1880 e Correio Paulistano, São Paulo, 17 dez. 1885.

${ }^{12}$ Irmão de Francisco Aguiar de Barros, esposo de Maria Angélica de Sousa Queiroz Aguiar de Barros, uma personagem que, como veremos, foi agente importante no "fazer-se" do trecho da cidade a que se dedica este estudo.

${ }^{13}$ A Nação, Rio de Janeiro, 2 set. 1887.

${ }^{14}$ A penetração de Hermann na alta sociedade também deu-se pelo casamento que contraiu com Anna Maria Moraes de Barros, filha de Manoel Moraes de Barros, eminente político durante o Império e a República. LEME, Luiz Gonzaga da Silva. Genealogia Paulistana. São Paulo: Ed. Duprat, 1905, Vol VII, p. 78.
} 
Imbuídos de seus rendimentos anteriores e de suas estreitas afinidades com as elites, em 1890, Burchard e Nothmann deram início às obras do Boulevard Burchard. A ideia de um bairro exclusivo para as elites não foi invenção da dupla alemã, contando já à época com experiências prévias (Campos Elíseos) e paralelas (Avenida Paulista) e com vasta ancoragem social no contexto paulistano - o desejo de deslocamento das elites do perímetro central já se pronunciava há algumas décadas. Mesmo sem a pretensão de serem exclusivas, as primeiras retiradas remetem às décadas de 1860 e 1870, com o loteamento das chácaras de Rafael Tobias de Aguiar e Antônio Paes de Barros, localizadas no entremeio da Estação da Luz e do bairro de Santa Ifigênia ${ }^{15}$.

Distando alguns quilômetros do Centro da Cidade, com o qual se conectava através da Rua Maria Antônia e da Rua D. Veridiana, pela recém-aberta Vila Buarque, o Boulevard foi resultado da aquisição de duas chácaras: a do Barão de Ramalho e a pertencente a Joaquim Floriano Wanderley. Lançado em duas etapas, o loteamento ocupou primeiramente as terras do Barão, arruadas e comercializadas a partir de 1891, enquanto as de Joaquim, localizadas mais ao ocidente, foram urbanizadas lentamente entre 1914 e $1924^{16}$ (FIG. 1 e 3).

Em anúncio veiculado pela dupla alemã entre 1894 e 1895, podemos apreender algumas de suas aspirações para a empresa:

\section{Boulevard Burchard}

São estes esplêndidos terrenos situados no ponto mais alto e mais saudável desta cidade, com linha de bondes em toda a Avenida Higienópolis, servidos também pelos bondes que percorrem a rua D. Veridiana, bem como já servidos com água, gás e esgoto.

\footnotetext{
${ }_{15}$ Ali, intercalados pelo casario geminado, surgiram os primeiros palacetes isolados em meio ao lote, rodeados por jardins e gradis de ferro. Contudo, apesar de ter abrigado parte expressiva das elites da época, é fundamental notar que o loteamento de Rafael Tobias ainda não possuía a pretensão de ser exclusivo, por isso não pode ser considerado um caso prévio ao aqui analisado, embora sem dúvidas esteja relacionado com a conformação do ideário dos "bairros exclusivos". CAMPOS, Eudes. Nos caminhos da Luz, antigos palacetes da elite paulistana. Anais do Museu Paulista, São Paulo, v. 13, n. 1, p. 11-57, Jun. 2005 e MARINS, op. cit.

${ }^{16}$ Apesar de Maria Cecília Naclério Homem datar o Boulevard de 1895, em 1891 Martim Burchard já colocava à venda terrenos do loteamento, juntamente com terrenos na Barra Funda, nos Campos Elíseos e nas Palmeiras, terras de Maria Angélica, que indicam que suas relações com os alsacianos já eram de longa data quando ambos se associarão na extensão da Itatiaia, em 1896. Correio Paulistano, 21 jun. 1891.
} 
Contém este aprazível bairro 14 ruas, todas arborizadas, com um aspecto delicioso.

Ali se acham situados os colégios "Ginásio Infantil", Ginásio Americano (Colégio Mackenzie) e em construção o Seminário Synobal da Igreja Presbiteriana de São Paulo, bem como em construção diversos prédios de muito gosto, o que tudo vai, cada vez mais, aumentando o valor aliás reconhecido daqueles terrenos.

Pela elevação destes terrenos, em uma boa altura acima da cidade, vê-se de todos os pontos os mais risonhos e encantadores panoramas.

Ficam assim prevenidos os srs. capitalistas de bom gosto para um bom emprego de capital.

Para informações, na Rua S. Bento, $59^{17}$

Uma redoma de conforto, salubridade e beleza ${ }^{18}$. Era essa a atmosfera que procuram vender à praça. Uma reedição do intento de Nothmann nos Campos Elíseos, que à altura já encontrava seu projeto inicial, ao menos em sua concretude,

\footnotetext{
${ }^{17}$ A data desse anúncio não é precisa, porém ele deve ter sido publicado entre 1894 e 1895, uma vez que neste último ano foi realizada a transferência do Seminário do Sínodo para a Igreja Presbiteriana de São Paulo, antes localizado em Nova Friburgo. O jornal em que foi publicado, contudo, não foi identificado. Nosso acesso ao documento foi feito a partir da consulta ao Acervo Particular do Escritório Administrativo de Germaine Lucie Burchard. Sobre a transferência do Seminário, Cf. MATOS, Aderi Souza de. Retrospectiva da IPB no século 20. s/d. Disponível em http://www.mackenzie.br/15614.98.html (último acesso em agosto de 2016).

Uma observação excepcional, por tratar-se do primeiro documento textual apresentado no trabalho: em todas as transcrições optei por atualizar a ortografia e a gramática para facilitar a leitura e interpretação do leitor.

${ }^{18}$ Paralelamente corriam loteamentos que se anunciavam da mesma maneira, como a Avenida Paulista e os Campos Elíseos, mas também havia tantos outros que eram propagandeados com outros intuitos, visando outras clientelas com outros desejos. Comparando este anúncio com outro publicado anos antes para a comercialização do Bexiga, podemos precisar a especificidade do discurso elitista dos alsacianos em relação ao discurso mais pragmático e moderado dos que comercializavam terras em outras áreas da cidade:

"Vendem-se magníficos terrenos às braças ou em grandes lotes, com pastos ou matas, à vontade do comprador. Não há nada a desejar nestes terrenos dentro da cidade, água corrente, em diversas fontes, lindos golpes de vista para as bonitas chácaras, ruas de 60 palmos de largura. Preços baratíssimos, desde $20 \$, 30 \$, 40 \$$ até $50 \$ 000$ a braça, com 30 braças e mais de fundo, conforme a localidade escolhida. A planta acha-se nas oficinas de Santo Antônio, no Bexiga, podendo ser examinado a qualquer hora, tanto a planta como os terrenos. Para tratar com proprietários na mesma oficina ou com E. Rangel Pestana, na Rua Imperatriz n. 44". A Província de São Paulo, 28 jul. 1878 apud. TODOROV, Mariana e CRISTOFI, Renato B. Bexiga. s/d. Disponível em: http://estrangeiros.fau.usp.br/page.php?name=artigo\&op=visualizar_mais\&id_artigo=36 (último acesso em fevereiro de 2017).
} 
prejudicado pela larga presença de casas geminadas e galpões industriais ${ }^{19}$. Direcionado aos abastados, sua materialidade é espelhada na promessa dos bairros socialmente especializados da Paris burguesa, cujos faubourgs e boulevards do VIIe e XVIe arrondissement caracterizavam-se por sua harmônica homogeneidade social, uso prioritariamente residencial, bucolismo e ostensiva pujança. As referências a esse ideário são patentes no anúncio. Perpassavam desde o nome dado ao empreendimento, os altos investimentos em infraestrutura, a alusão à suas construções de "muito bom gosto", até as vias retilíneas e arborizadas, tomando de empréstimo da capital francesa seu imaginário de elegância e bem-estar, assim como a atmosfera de "bom gosto" de tudo o que dali provinha ${ }^{20}$.

Através de seus agigantados investimentos, incomuns nos loteamentos da época ${ }^{21}$, Nothmann e Burchard pretendiam conquistar parte dos afortunados que paulatinamente desejavam mais exclusividade e isolamento ${ }^{22}$. Essa clientela, por sua

\footnotetext{
${ }^{19}$ MARINS, op. cit.

${ }^{20}$ Seguindo a explicação de Marins, as referências a essas espacialidades provinham dos faubourgs consolidados pela burguesia parisiense no século XIX, como Chaillot, Portre, Dauphine, e não os conformados pela aristocracia a partir do século anterior, como St. Germain e St. Honoré. MARINS, op. cit., p. 229.

${ }^{21}$ Certas qualidades materiais apresentadas no anúncio, apesar de poderem parecer triviais aos olhos atuais, eram de extrema singularidade à época. A infraestrutura básica - transporte, saneamento (água), esgoto e energia (gás), por exemplo - era raramente organizada e bancada pelos empreendedores de loteamentos, que geralmente deixavam os esforços à cargo da municipalidade. Assim, eram extremamente frequentes as queixas e longas disputas dos habitantes dos arrabaldes para a conquista dessas estruturas basais. Nesse universo, um loteamento com toda infraestrutura e ainda mais com planejamento paisagístico e em terreno elevado, com alta salubridade, sem dúvida representava um evento singular. As qualidades oferecidas por Burchard e Nothmann certamente visavam o conforto, mas também a distinção, tendo em vista que conformavam um espaço que ocupava posição diametralmente oposta à maioria dos loteamentos até então existentes na cidade. Sobre os padrões mais frequentes de loteamento à época, Cf. BRITO, 2000 e SIMONI, 2002. Sobre os embates de seus moradores com a municipalidade para a realização de melhorias e instalação de infraestrutura, Cf. CERASOLI, Josianne Francia. Modernização no plural: obras públicas, tensões sociais e cidadania na passagem do século XIX para o XX. Tese (Doutorado) - IFCH-UNICAMP, 2004.

${ }^{22}$ Embora muitos abastados tenham se dirigido para os loteamentos da expansão Oeste da cidade, é importante ressaltar que houve muitas outras trajetórias e destinos na cidade, como podemos constatar pelos palacetes ainda hoje presentes no Ipiranga, na Vila Mariana, em Santana, no Bexiga e no Belenzinho. Alguns desses loteamentos e ocupações ainda não tiveram estudos próprios, e através deles pode-se talvez compreender trajetórias de enriquecimento e distinção diferentes das buscadas pelos que se dirigiam a Higienópolis, Campos Elíseos, etc. Conferir o mapa feito por Maria Cecília Naclério Homem em $O$ palacete paulistano, no qual ela analisa as chácaras em que foram construídos ao menos alguns palacetes na virada do século XIX para o XX. Embora a autora raramente aborde outras localidades a não ser Higienópolis, Campos Elíseos e Avenida Paulista ao longo de seu livro, esse mapa pode servir de guia
} 
vez, longe de almejar um simples pavoneio, tinha seu anseio ancorado em um rol de estratégias elaboradas para encarar os desafios socioeconômicos, psicofísicos e políticos de uma nova época. Afinal, nas últimas décadas do século XIX as mudanças não eram poucas.

A inserção da economia cafeeira no capitalismo internacional, a desenfreada metropolização, a Abolição da Escravatura e a Proclamação da República inauguravam um novo jogo, com novas regras, novos poderes, novos limites, novos conflitos, novos agentes e novas possibilidades. Nesse universo, emergiam novas forma de conduta individual que eram ao mesmo tempo socialmente constituídas e constituidoras da emergente organização social. Mais precisamente: desenvolviam-se novos habitus, congenitamente com as novas delimitações das classes sociais ${ }^{23}$.

É através do emergente habitus das elites, em parte coincidente com o dos mais abastados setores médios, que podemos compreender por que Higienópolis tornava-se um lugar desejado e atraente para esses grupos. Para tanto, precisaremos apreender esse habitus em suas nuances de gênero. O papel social destinado aos homens abrangia liderar moralmente o seu clã e prover a família com recursos através do trabalho, meio pelo qual também concretizavam sua participação e contribuição para o desenvolvimento dos setores públicos e privados. Para além do âmbito familiar, onde travam primeiro contato com tais imperativos, estes eram reforçados ao longo de seu convívio social e institucional, com destaque à dominância dos discursos médicossanitaristas que lhes creditavam, através de argumentos biológicos, os atributos necessários a uma conduta retilínea e ao enfrentamento da luta diária: seriam dotados de superior resistência física, estabilidade emocional e capacidade intelectual e racional $^{24}$.

Esse habitus era reforçado pelas privilegiadas posições sociais que ocupavam os abastados, que lhes permitiam aproveitar um amplo espectro de possibilidades que se

para futuras pesquisas. HOMEM, Maria Cecília Naclério. O palacete paulistano e outras formas de morar da elite cafeeira. São Paulo: Ed. Martins Fontes, 1996, p. 82-83.

${ }^{23}$ Cf. reflexões em torno de nossa utilização do conceito de habitus na Introdução deste trabalho.

${ }^{24}$ Cf. FREIRE, Jurandir da Costa. Ordem médica e norma familiar. Rio de Janeiro: Graal, 1989 e CARVALHO, Vania Carneiro de. Gênero e Artefato: o sistema doméstico na perspectiva da cultura material - São Paulo 1870-1920. São Paulo: Edusp, 2008, p. 43-68 e 134-156. 
abriam na metrópole. Afinal, o tremendo crescimento da economia cafeeira e da cidade criaram e impulsionaram numerosas atividades econômicas. Sem contar que, com a República, as oportunidades políticas se multiplicavam para os paulistanos: além da ampliação dos poderes municipais, os moradores da capital passavam a ter preponderância nos cargos executivos e legislativos das esferas estadual e federal. Paralelamente à pujante abertura de oportunidades, aumentavam os contingentes abastados que chegavam ou se formavam na capital, resultando em uma agressiva e progressiva ampliação da competitividade. $\mathrm{O}$ dinamismo da rivalidade e das possantes oportunidades ampliava a velocidade e a intensidade da mobilidade dentro de cada classe e entre elas.

Essa dinâmica resultava em uma ambígua vivência para as elites: ao mesmo tempo em que ficavam instigados e afoitos por ascender, temiam pavorosamente serem ultrapassados, ou pior, incorrerem nos deslizes que poderiam conduzir a descenso. Assim, entre os homens, o afinco ao trabalho, aos negócios e à carreira pública acentuava-se radicalmente, uma tenacidade que surtia violentos efeitos psicofísicos e emocionais. Essa faina era vivenciada em meio ao cotidiano crescentemente turbulento do Centro, no qual o avolumamento de atividades e corpos intensificava o estresse, amplificava os estímulos sensoriais e colocava em rota de choque os diferentes ritmos e modos de vida das diferentes classes ${ }^{25}$.

“Todo homem que trabalha na indústria, no comércio, nas artes e na ciência [...] precisa das horas de descanso do corpo e espírito, esquecendo um pouco das lutas espinhosas da vida”. Foi com essas palavras que Durval, em julho de 1894, propagandeava sua visita ao "aprazível arrabalde" de Burchard e Nothmann ${ }^{26}$. A busca pelo descanso, pelo apaziguamento psíquico e pela recuperação diária das energias físicas tornava-se um imperativo complementar ao afinco laboral no habitus dos abastados $^{27}$. O ambiente doméstico, como veremos no terceiro capítulo, foi eleito

\footnotetext{
${ }^{25}$ Exploraremos esse tópico mais profundamente nos capítulos terceiro e quinto deste trabalho.

${ }^{26}$ DURVAL. "Aprazível Arrabalde". Correio Paulistano, São Paulo, 2 out. 1894.

${ }^{27}$ As reflexões a respeito do habitus masculino dos abastados apresentadas a seguir foram pautadas nos estudos de CARVALHO, op. cit., p. 195-219; GAY, Peter. O século de Schnitzler. A formação da cultura de classe média. 1815-1914. São Paulo: Companhia das Letras, 2002; VALENCIANO, Jésus Cruz. El surgimiento de la cultura burguesa. personas, hogares y ciudades en la españa del siglo XIX. Madrid: Siglo
} 
espaço primordial de contraponto à tormentosa experiência da metrópole e da vida laboral. Daí o anseio por esvair-se dos sons, imagens e corpos das ruas centrais em busca de ambientes praticamente antiurbanos, silenciosos, com baixa densidade, exclusivamente residenciais, privativos de sua classe social e onde as invenções da modernidade pudessem encontrar harmônica confluência com o bucolismo da natureza.

Ao propagandear o bairro, não foram irrefletidos os adjetivos e predicados empregados pela dupla alemã. Era um bairro "aprazível [...] com ruas, todas arborizadas, com um aspecto delicioso". O "ponto mais alto" da cidade, uma arquetípica imagem de isolamento e reclusão, era acentuada pela sugestão de abrandamento ao ver-se dali "todos os pontos os mais risonhos e encantadores panoramas". Ao mesmo tempo, o bucolismo dominante era contrabalanceado por elementos modernos de conforto e bem-estar, como os bondes e a pré-instalação de água, gás e esgoto. Um quadro complementado pela menção à sofisticação dos “diversos prédios de muito gosto" que ali já estavam em construção, e por seu direcionamento particular aos "capitalistas de bom gosto", que somavam à distância do Centro a cobiçada marca da exclusividade.

XXI, 2014; PROST, Antoine. O trabalho. In: PROST, Antoine e VINCENT, Gérard. História da Vida Privada: da Primeira Guerra aos nossos dias. São Paulo: Companhia das Letras, 1992, vol. 5, p. 21-61; PROST, Antoine. A família e o indivíduo. In: PROST, Antoine e VINCENT, Gérard, op. cit., p. 61-115; ARIĖS, Phillipe. História social da criança e da família. Rio de Janeiro: Zahar Editores, 1978, p. 195-275; e SILVA, Joana Mello de Carvalho e FERREIRA, Pedro Beresin Schleder. Os sentidos do morar em três atos: representação, conforto e privacidade (ainda inédito). Para além dos autores mencionados, como indica o artigo inédito apontado, devo grande parte dessas reflexões às aulas e interlocuções mantidas com a Profa. Joana Mello de Carvalho e Silva durante os últimos três anos.

Importante notar que alguns autores, como Vânia Carvalho e Peter Gay, apesar de definirem seu objeto como "setores médios", centram grande parte de suas reflexões nas porções mais elevadas dessa heterogênea classe social. Ao ponto de que, muitas vezes, remetem a comportamentos e materialidades das elites como base para suas reflexões. Com isso, queremos apontar que entre os setores médios mais abastados e as elites, as fronteiras eram extremamente tênues e evasivas. Com certeza existiam, mas talvez em aspectos que não são relevantes, ao menos nesse momento, para o presente trabalho. Por isso, abordamos ambos os grupos conjuntamente, sob a alcunha de abastados ou simplesmente elites. E, por isso, nos apropriamos de grande parte das interpretações de Carvalho e Gay, a nosso ver, sem enganos, pois apesar das nomenclaturas distintas, parece-nos que suas reflexões são próprias ao grupo aqui abordado. Como setores médios, por sua vez, reconheceremos aqui aqueles que efetivamente possuíam capitais - sociais, econômicos e culturais -, poderes e privilégios bastante reduzidos em comparação aos mais abastados. 
A mesma associação era ressaltada em cartaz da "Cia de Bonds Hygienopolis", também veiculada pelos alsacianos ${ }^{28}$. Na ilustração, a vista em "voo de pássaro" exaltava a harmônica relação do empreendimento com seu entorno, destacando sua intermediação por uma área urbanizada (à esquerda) e outra campestre (à direita). Maximizava a magnitude do espaço, dos ares e das vistas com o profundo respiro deixado à amplitude do céu. O casario aparece espaçado e entremeado por arvoredos e circundado por chácaras e vias retilíneas com bondes, uma fina e equilibrada proporção entre modernidade, natureza, conforto e isolamento (FIG. 4).

Se a vida dos homens transcorria predominantemente no Centro, sendo o arrabalde a fuga de sua aprisionadora e tormentosa rotina, a vida das mulheres passava em sentido oposto: o além-cidade era seu tempo ordinário, que era por vezes interrompido por breves e pontuais passeios na urbe. Eram outros os imperativos de seu habitus. Seu papel na sociedade estava atrelado ao cuidado - afetivo e emocional da prole e do marido, à manutenção do lar e à representação social da família. Essas funções apoiavam-se nos predicados que atribuíam à sua natureza biológica a inclinação inata ao amor materno e ao cuidado dos outros, o frágil condicionamento corporal e à predominância do afeto e da emoção em sua psique. Se por um lado essa suposta composição mental lhe tornava uma hábil e galante conversadora nas situações de sociabilidade, acompanhada de uma apurada sensibilidade estética, por outro lhe atribuía severas disfuncionalidades: instabilidade emocional e moral, ingenuidade e propensão à irracionalidade.

O significado predominante para a vida da mulher nos arrabaldes era a segurança. Resguardo da cidade, conformado muito menos por seus tormentos mentais e psíquicos do que por sua ameaça moral. Se a instituição suprema do homem era o trabalho, a da mulher era o casamento. Para conquistá-lo quando jovem, ainda mais um de boa procedência, era necessário conservar a castidade, pois a pureza ainda figurava como atributo central da honra individual e familiar. Dada a crença em sua instabilidade emocional, que poderia acarretar em irruptivos desvios morais, i.e.,

\footnotetext{
${ }^{28}$ Não consegui determinar a data precisa do documento, mas é certamente anterior a 1896, pois a Rua Itatiaia não é apresentada com seus prolongamentos até a Avenida Paulista e a Rua das Palmeiras. Pelo contrário, ela é apresentada apenas como mais uma via local, de pouca expressividade.
} 
sexuais, a família lhe inculcava a necessidade da reclusão e do recato. No ambiente doméstico, suas entrevistas amorosas poderiam ser vigiadas e devidamente controladas. Uma gerência extremamente facilitada pelo aniquilamento das conversas fiadas e galanteios com o desligamento das janelas e portas da rua, e sobretudo pelas amplas distâncias dali até a cidade, que dificultavam uma súbita e aventurosa escapulida. Com o ideal de exclusividade, além do mais, se esperava que ao redor houvesse apenas moços de boa índole e generoso berço, que raramente representariam um risco aos interesses da família ${ }^{29}$.

Além do mais, era no lar, junto à mãe e através da própria materialidade e dinâmica cotidiana da casa, que a mulher aprendia suas principais lições. Muitas, inclusive, eram educadas por preceptoras domésticas, e aquelas que iam para a escola tinham seu currículo limitado no ginásio. Poucas, como veremos, chegavam até a faculdade e iniciavam uma vida profissional, que não raro era interrompida quando a sua função primordial era alcançada: o casamento e a constituição de uma nova família. Para esse fim, seu treinamento era intenso e diário. Observava a mãe dar ordens e recomendações aos empregados. Absorvia os princípios da economia doméstica. Analisava o comportamento perante o marido e os cuidados necessários para com os filhos. Assimilava os regimentos do gosto decorativo e da arte de se vestir. Adestrava seu corpo e fala para as conveniências da recepção e aos rarefeitos e penetrantes jogos da sedução. Uma série de aprendizados que eram praticados entre amigos e irmãos, e que era objeto das miméticas brincadeiras de casinha, de maquiagem e de boneca.

Fora do lar, cabiam-lhe poucas, porém importantes tarefas. Para além da escola e dos passeios, às mães e às jovens competiam a manutenção e construção de laços sociais com outras famílias. Compareciam a festejos, cerimônias religiosas, espetáculos

\footnotetext{
${ }^{29}$ As reflexões apresentadas a seguir sobre o habitus feminino dos abastados foram baseadas nos estudos de FREIRE, op. cit., 255-271; CARVALHO, op. cit., p. 68-117; SANTOS, Simone Andriani. Senhoras e criadas no espaço doméstico, São Paulo (1875-1928). Dissertação (Mestrado) - FFLCH-USP, 2015, p. 5688; PROST, Antoine. A família e o indivíduo. In: PROST, Antoine e VINCENT, Gérard, op. cit., p. 61-115 e ARIẼS, Phillipe, op. cit., p. 195-275. Igualmente quanto aos temas masculinos, devo também grande parte dessas reflexões às aulas e interlocuções mantidas com a Profa. Joana Mello de Carvalho e Silva durante os últimos três anos.
} 
de teatro e circulavam nas ruas comerciais. Mas esses encontros davam-se primordialmente nas recepções, chás e jantares que eram organizados nas próprias residências. Essa atividade, aparentemente frívola, constituía praticamente um ofício, que em outro contexto Mimi Hellman denominou de "o trabalho do lazer" 30 . Para a esposa, era o momento de estreitar e ampliar os elos econômicos de seus maridos através da vinculação com figuras de proeminentes famílias. Para fazê-lo, ela constitua a si mesma como uma fina representação das virtudes de seu clã. A começar pelo volumoso ordenado do marido, expresso nas joias e roupas, mas também em sua própria rotina, pois lhe permitia uma vida aristocrática, distante do laboro. Seguiam-se as demonstrações de bom gosto e de domínio da alta cultura, que se misturavam nas sedutoras interações, nas quais procurava exibir-se conveniente e extremamente interessante. À filha, o jogo era semelhante, porém colocava-se no meio social como uma luxuosa mercadoria. Suas vestes e adereços davam a medida do dote que prometia. Nas interações, não só exibia educação e delicadeza na convivência, na aparência, no vestir-se e no gestual, mas também quando se punha à exibição de suas habilidades artísticas, como o tão corrente toque ao piano. Tudo para conquistar o encanto de um bom e próspero rapaz, que afiançaria bons rendimentos à família, se responsabilizaria por sua vida material e lhe daria a oportunidade de concretizar sua máxima aspiração: constituir, criar e cuidar de uma família.

O “trabalho do lazer” feminino era a expressão de uma dimensão global do habitus das elites: a obsessão por construir representações de si. Impulsionavam o movimento desse mecanismo a mobilidade social, a ampliação da competitividade e a inédita experiência do anonimato, propiciada pelo crescimento demográfico e espacial, assim

\footnotetext{
${ }^{30} \mathrm{O}$ texto de Hellman a que me refiro trata da vida nas cortes francesas do Setecentos, contudo, a ideia do lazer como uma forma produtiva de capitais simbólicos e sociais também parece aplicável às práticas observadas no cotidiano das mulheres abastadas dos séculos XIX e começo do XX. Ideia semelhante também foi utilizada por CARVALHO, 2008, p. 219-241. HELLMAN, Mimi. Interior motives: seduction by decoration in eighteenth-century France. In: KODA, Harold et al. Dangerous liasons: Fashion and Furniture in the Eighteenth Century. Nova York: Metropolitan Museum of Art, 2006, p. 15-25. Apesar de apresentar essa forma de trabalho aqui sob o âmbito feminino, é importante notar que, principalmente entre as elites, essa forma produtiva também era realizada pelos homens, que frequentavam os clubes e sociedades elitizadas da cidade - Clube Atlético Paulistano, Clube Germânia, Sociedade Hípica Paulista, Sociedade de Cultura Artística, Automóvel Clube - e igualmente compareciam ao teatro e às festas e jantares.
} 
como pelo enfraquecimento dos rígidos elos hierárquicos vivenciados anteriormente ${ }^{31}$. Nesse cenário, o cultivo e a conquista dos privilégios socioeconômicos e políticos passaram a atrelar-se a colossais ritos e aparatos de representação, verdadeiras vitrines nas quais os indivíduos procuravam exibir-se como a mais rara e luxuosa mercadoria, ansiosos pela conquista de lucrativas e profícuas relações. Sem contar que, através desses ritos, constituíam altas e espessas fronteiras de comportamento, conhecimento e consumo aos que quisessem aventurar-se em uma meteórica ascensão. Os ritos e mecanismos de representação eram ao mesmo tempo artifícios utilizados para a competição interna entre as elites e para a garantia da supremacia destas perante as outras classes ${ }^{32}$.

Nesse contexto, à semelhança do que ocorreu na França e na Inglaterra no começo do Oitocentos, intensificam-se a aquisição e construção de objetos cada vez mais calculados e meticulosos. Objetos não apenas ostensivos e sofisticados, mas também capazes de comunicar mensagens mais complexas, como a adesão a um certo ideário, pertencimento a um grupo ou filiação a certa identidade. Objetos que, como veremos no capítulo segundo, eram capazes de contarem histórias por si, longos enredos celebrativos de seus proprietários. Por sua magnitude e imponência, a casa, um dos maiores e mais complexos artefatos da vida cotidiana, tornara-se um elemento central nesse jogo. Ainda mais em tempos em que a sociabilidade, como vimos, era largamente centrada no ambiente doméstico. Esse profundo desejo de representação era o alvo da insistência de Nothmann e Burchard em caracterizar casas e moradores do bairro como "de muito bom gosto". O bairro em si vendia-se como uma marca de distinção. Além do mais, como veremos, a sua espacialidade fora meticulosamente planejada para funcionar como uma passarela por onde desfilariam os proprietários em meio ao corso de suas residências-monumento e majestosos jardins.

\footnotetext{
${ }^{31}$ Aqui me refiro aos estreitos laços de estratificação social mantidos pelo escravismo e pela organização monárquica, que são paulatinamente desmobilizados com a ascensão do trabalho livre e do regime republicano.

${ }^{32} \mathrm{O}$ pilar central dessa interpretação são as reflexões de Pierre Bourdieu em BOURDIEU, Pierre e SAINTMARTIN, Monique de. Gostos de classe e estilos de vida. In: ORTIZ, Renato (org.). Bourdieu Sociologia. São Paulo: Ática, 1983, p.82-121 e BOURDIEU, Pierre. A Distinção: crítica social do julgamento. São Paulo/Porto Alegre: Edusp e Ed. Zouk, 2007.
} 
Por fim, não podemos esquecer um dos domínios centrais do habitus das elites: a salubridade. Um conceito de higiene que era extremamente volúvel e confusamente extensivo, uma espécie de panaceia de todos os males da sociedade. Um absurdo sintetizado na ironia de Machado de Assis, que atribuíra a Brás Cubas a insana utopia de inventar um miraculoso emplastro capaz de aliviar toda "nossa melancólica humanidade" ${ }^{33}$. Além de garantirem a higiene mental e física da tóxica rotina, os arrabaldes eram também artifícios de higiene social. Afinal, todos os males sociais eram atribuídos à pobreza, desde a violência, a imoralidade, o vício, as desordens mentais e até as doenças orgânicas. Essa representação da pobreza e dos pobres tornava as elites histéricas, tornando mais acentuada a ideia de fuga em sua retirada aos arrabaldes. Na Polis da Higiene, acreditavam estarem a salvo dos corpos e casas sujos e de toda a complexa humanidade que eles representavam ${ }^{34}$.

\section{Um sonho lento e turbulento: uma ocupação errante}

Em outubro de 1897, Martinho Burchard dirige requerimento à Câmara Municipal para que "todos os prédios que se construírem nas Avenidas Higienópolis e

\footnotetext{
${ }^{33}$ ASSIS, Machado de. Memórias Póstumas de Brás Cubas. Rio de Janeiro: Editora Nova Aguilar, 1994,p. 4.

${ }^{34}$ Dentre os diversos estudos que dissertam sobre o tema, nos apoiamos nas reflexões de CARPINTÉRIO, Maria Varanda Teixeira. Imagens do conforto: a casa operária nas primeiras décadas do séc. XX em São Paulo. In: BRESCIANI, Stella (org.). Imagens da Cidade. São Paulo: Ed. Marco Zero, 1994; FORTY, Adrián. Higiene e limpeza. In: Objeto de desejo - design e sociedade desde 1750. São Paulo: Cosac Naify, 2007, p. 215-246; FREIRE, 1989; BEGUIN, François. As maquinarias inglesas do conforto. Espaço e Debates n ${ }^{\circ} 34,1991$, pp. 39-54; CORREIA, Telma de Barros. A construção do habitat moderno no Brasil 1870-1950. São Carlos: RiMa, 2004; LEMOS, Carlos A.C. A república ensina a morar (melhor). São Paulo: Hucitec, 1999; TELAROLLI JUNIOR, Rodolpho. Imigração e epidemias no estado de São Paulo. Hist. cienc. saude-Manguinhos [online]. 1996, vol. 3, n. 2, p. 265-283; CORDEIRO, Simone Lucena. Os Cortiços de Santa Ifigênia: sanitarismo e urbanização. São Paulo: Imprensa Oficial e Arquivo Público do Estado de São Paulo, 2010; e MASTROMAURO, Giovana Carla. Surtos epidêmicos, teoria miasmática e teoria bacteriológica: instrumentos de intervenção nos comportamentos dos habitantes da cidade do século XIX e início do XX. XXVI Simpósio Nacional de História - ANPUH. Anais: São Paulo, 2011. Disponível em: http://www.snh2011.anpuh.org/resources/anais/14/1300472386_ARQUIVO_Mastromauro.pdf (último acesso em fevereiro de 2017).
} 
Itatiaia $^{35}$ tenham um nivelamento retirado seis metros da face das ditas Avenidas"36. Pedidos dessa ordem, que procuravam respaldo legislativo para a ocupação exclusiva de uma região, não eram novidade, já realizados por Joaquim Eugenio de Lima, em 1893, e anteriormente, embora por meio diverso, por Frederico Glette, em $1878^{37}$. Se não espanta por seu conteúdo, a requisição de Burchard surpreende por seu atraso, posto que é realizada apenas seis anos após o lançamento de seu Boulevard.

Para entender esse descompasso, é forçoso retomar o peculiar desenvolvimento de seu arruamento. Circunscrito às catorze ruas originais, em seu princípio, o Boulevard contava com duas vias de acesso: a Rua Dona Veridiana, que o ligava à Vila Buarque e Santa Cecília; e a Rua Maria Antonia, que o congregava à Consolação e ao Centro Novo. A Itatiaia, como podemos observar na propaganda dos bondes Higienópolis, resumia-se a uma via local, ligando a Rua Pará à Avenida Burchard ${ }^{38}$, fronteiriça ao meio rural pelo atraso na abertura da segunda fase do loteamento, condição que começa a ser transformada apenas na década de 1910, com a paulatina abertura da Rua Bahia, da Rua Ceará e da Rua Minas Gerais.

No mapa realizado por Hugo Bonvicini em 1895, vê-se que os negociantes hesitavam em estender a via na direção da Paulista, terminando-a no cruzamento com uma via curvilínea, que aparece em projeção ${ }^{39}$. O vacilo parece residir na incompatibilidade das terras acima da Rua Pará com o projeto elitista da dupla, uma

\footnotetext{
${ }^{35}$ Denominação primeira da via que hoje conhecemos como Avenida Angélica, contudo apenas na área compreendida pela Avenida Burchard e a Avenida Paulista. Entre a Burchard e a Rua das Palmeiras, a via já era denominada Avenida Angélica à época.

${ }^{36}$ Atas da Câmara da Cidade de São Paulo, 1897, vol. 2, p. 157 e 177.

37 Tentativa semelhante de regulamentação havia sido realizada anos antes por Frederico Glette, sócio de Nothmann no empreendimento dos Campos Elíseos. Através de normas cartoriais para a transmissão dos terrenos, os loteadores tentaram firmar com seus clientes o compromisso de que todas as edificações seriam recuadas das vias, donde seriam realizados jardins fronteiriços, tendo os alinhamentos demarcados por gradis de ferro. MARINS, 2011, p. 214.

${ }^{38}$ Hoje conhecida como Avenida Higienópolis.

39 À semelhança do mapa de 1897, estudado por Simoni (2009) e Kuvasney (2016), o mapa de Bonvicini parece ter sido formalizado no entrecruzamento dos levantamentos realizados pela Intendência de Obras e as consultas realizadas com proprietários a respeito de suas intenções de arruamento. Afinal, neste há evidentemente um esboço projetivo de prolongamento da Itatiaia que nunca foi realizado. SIMONI, Lucia Noemia. A planta da cidade de São Paulo de 1897: uma cartografia da cidade existente ou da cidade futura? In: SIMPÓSIO LUSO-BRASILEIRO DE CARTOGRAFIA HISTÓRICA. Anais: Ouro Preto: UFMG, 2009 e KUVASNEY, Eliane. Os mapas como “operadores espaciais” na construção da cidade de São Paulo do início do século XX. Revista do Instituto de Estudos Brasileiros, Brasil, n. 64, p. 167-182, ago. 2016.
} 
vez que tinham como vizinhança o Cemitério e, mais à frente, o Hospital de Isolamento, duas localizações estigmatizadas pelo sanitarismo corrente ${ }^{40}$. Conquanto, no mesmo mapa, vê-se que seu prolongamento no sentido da Barra Funda já era ansiado, porém não pela dupla alemã, mas por Maria Angélica de Sousa Queiroz Aguiar de Barros, ávida em urbanizar sua Chácara das Palmeiras ${ }^{41}$ (FIG. 2 e 6).

Contudo, as extensões só começaram a tomar corpo em 1896, quando o presidente da Câmara Municipal, Antonio Proost Rodovalho - como já vimos, um regular parceiro comercial de Nothmann - anuncia o projeto de construção de uma Avenida Circular conectando "terrenos junto ao largo de S. Francisco, alto do Paraíso, ligando as Avenidas Paulista, Burchard, da Luz" e seguindo até a Vila Mariana ${ }^{42}$. A despeito da alcunha remeter à locomoção na cidade, o projeto, longe de configurar uma perimetral completa, contemplava apenas as áreas de expansão com predomínio das classes médias e altas, ignorando os bairros com população primordialmente trabalhadora, situados nas porções norte e leste da cidade, favorecendo antes um passeio para o desfrute das classes elevadas e expressão de seu poderio simbólico do que um efetivo desafogo viário ${ }^{43}$ (FIG. 5).

\footnotetext{
${ }^{40}$ Para além do temor dos miasmas, as redondezas e interiores do Cemitério também congregavam comumente práticas sexuais e de sociabilidade dos trabalhadores e menos remediados, como aprofundaremos no capítulo quinto deste trabalho.

${ }^{41}$ De acordo com a genealogia de Silva Leme, Maria Angélica era filha de Francisco Antonio de Sousa Queiroz, barão de Sousa Queiroz e Senador do Império, além de abastado fazendeiro e proprietário em São Paulo. Sua mãe era Antonia Eufrozina Vergueiro, baronesa do mesmo título. Maria Angélica fora casada com seu primo Francisco Aguiar de Barros, falecido em 1891, filho de Bento Pais de Barros, barão de Itu, também um portentoso fazendeiro, e de Leonarda de Aguiar (LEME, 1905, p. 393-397). O casal habitava a Chácara das Palmeiras desde 1874, sendo ali construído um suntuoso palacete em $1890 . \mathrm{Na}$ mesma época, após a morte do marido, Maria Angélica começa a intencionar lotear sua Chácara, como pudemos observar em anúncio de vendas de terras ali realizado por Burchard, em 1891. Intenção que também podemos perceber no mapa de 1895, no qual aparece projetada uma via em tracejado, ladeando uma das faces de suas terras, que parte da Rua das Palmeiras em direção à Avenida Burchard, com a alcunha de "Vianna Barros", em clara referência ao seu clã e a outro com o qual provavelmente pretendia se associar no empreendimento, que ao final fora realizado em parceria com os alsacianos Nothmann e Burchard (FIG. 2). Para mais informações sobre o clã dos Pais de Barros, ao qual pertencia o pai de Francisco Aguiar, ver CAMPOS, Eudes. Os Pais de Barros e a Imperial Cidade de São Paulo. Informativo do Arquivo Histórico Municipal. São Paulo, jan/fev. 2008, ano 3, n. 16. Disponível em: http://www.arquiamigos.org.br/info/info16/i-estudos.htm (Acessado pela última vez em fevereiro de 2017). Para mais informações sobre Maria Angélica de Souza Queiroz Aguiar de Barros, ver HOMEM, 1996, p. 57-163.

${ }^{42}$ Jornal do Commercio, Rio de Janeiro, 14 jan. 1896, p. 5.

${ }^{43}$ Sobre a gestão de Gomes Cardim e o projeto da Avenida Circular, ver CAMPOS NETO, Candido Malta. Os rumos da cidade: urbanismo e modernização em São Paulo. São Paulo: ed. Senac, 2000, p.73-76.
} 
A conexão da Avenida Paulista com a Avenida Burchard e com a Luz poderia ser realizada por duas vias já existentes, a Rua Dona Veridiana e a Consolação, ambas com trilhos de bonde instalados e em pleno funcionamento. A primeira, já contando com ligação até a Rua das Palmeiras, precisaria apenas ser prolongada até a Paulista, enquanto a Consolação, já plenamente estabelecida em todo o trajeto, demandaria apenas obras de embelezamento e paisagismo para adequar-se ao deleite almejado no passadiço de escol. Porém, sobre a última pesava ainda mais fortemente a morbidez simbólica do Cemitério.

Sem dúvidas eram opções menos onerosas aos cofres públicos do que a Itatiaia, que precisava ser prolongada em direção a Paulista e Palmeiras, sem contar as obras para instalação de trilhos, paisagismo, calçamento, etc. Contudo, apesar de ultrapassar as outras em custo e empenho, a via de Nothmann e Burchard é preferida pela municipalidade. Distante da objetividade administrativa, seu diferencial parecia residir em seu potencial simbólico e na inclinação dos interesses públicos pelos anseios $\operatorname{privados}^{44}$. O prolongamento da Itatiaia indubitavelmente favorecia grandes proprietários da região com loteamentos recém-inaugurados, em vias de expansão, ou somente em planos, porém todos com grande penetração na política local. Entre esses, destacam-se a já referida Maria Angélica de Sousa Queiroz Aguiar de Barros, parente do vereador Antonio Francisco Aguiar de Barros, então vice-presidente da Câmara; Domingos José Nogueira Jaguaribe ${ }^{45}$, que acabara de principiar o loteamento de Santa Cecília; Veridiana da Silva Prado, proprietária das terras que intermediavam as terras

\footnotetext{
${ }^{44} \mathrm{~A}$ irrelevância da Itatiaia como um eixo de grande tráfego da cidade pode se observada pelo simples fato de que, diferentemente da Avenida Higienópolis e da Rua da Consolação, que têm seus bondes elétricos instalados no primeiro ano de sua inauguração, 1900, os elétricos chegaram à Angélica apenas doze anos depois, em 1912.

${ }^{45}$ De acordo com o Dicionário de Ruas do Arquivo Histórico de São Paulo: "Dr. Domingos José Nogueira Jaguaribe, nascido em Fortaleza, Ceará, em 02 de novembro de 1848. Formou-se em Medicina pela Faculdade do Rio de Janeiro. Foi deputado pela sua Província natal na última legislatura do Império e em várias legislaturas provinciais de São Paulo. Aqui residiu durante longos anos, conquistando sólidas amizades e grangeando fama de homem culto e extraordinariamente trabalhador. A ele, juntamente com Antonio Piza e Estevão Leão Bourroul, deve-se a iniciativa da fundação do Instituto Histórico de São Paulo. Ávido de conhecimentos científicos e históricos, deixou também grande número de trabalhos interessantes sobre os mais variados assuntos. Foi o fundador, em São Paulo, do Instituto Psicofisiológico, em maio de 1901. Faleceu em São Paulo em 14 de novembro de 1926". DICIONÁRIO DE RUAS DE SÃO PAULO, "Rua Jaguaribe". Disponível em: http://www.dicionarioderuas.prefeitura.sp.gov.br/ (acessado pela última vez em fevereiro de 2017).
} 
do Boulevard e de Jaguaribe; sem falar de Antônio da Silva Prado ${ }^{46}$, futuro prefeito da cidade, que de imediato tentou estender a via até sua Chácara do Carvalho, loteamento que tentava vingar na vizinhança dos Campos Elíseos (FIG. 2).

Burchard e Nothmann, que também teriam colossal incremento no mercado com a passagem da Avenida por suas cercanias, mais do que integrados à dança, parecem ter conduzido a valsa. Se em 1895 mostravam-se hesitantes perante à extensão da Itatiaia, com o projeto da municipalidade a via passou ao cerne de suas preocupações. Já em 1896 realizam sua extensão em direção ao topo do Caaguaçú, e em 1897, além do requerimento que regulamentava sua ocupação, se oferecem à Câmara para realizar seu prolongamento em direção às Palmeiras, o qual é concretizado no mesmo ano, em parceria com Maria Angélica de Sousa Queiroz, que cede suas terras para a obra.

Vê-se que, à maneira de outros empresários da urbanização, como Joaquim Eugenio de Lima, a dupla alemã aproveitou-se da desorganização municipal, decorrente do inédito e célere crescimento da cidade e das transformações nas estruturas de poder decorrentes da recém-proclamada República, para ocupar, a partir de uma posição privada, responsabilidades propositivas características dos cargos públicos ${ }^{47}$. Dada a indefinição quanto aos direitos e deveres específicos dos universos particulares e coletivos, atuam em posição ambivalente, recorrendo à ação policial e regulamentar do Estado para garantir favorecimentos pessoais. Assim o fazem ao propor recuos para as avenidas do Boulevard, ao requisitar a proibição da passagem de gado por suas terras e ao oferecerem ao município serviços e obras que não foram requisitadas pela municipalidade, como o prolongamento da Itatiaia até a Rua das Palmeiras. A dita extensão provocou certo alarde na Câmara, uma vez que Burchard requisitou pagamento pela empreitada somente após ela ter sido completada, alegando tratar-se de um melhoramento de caráter público. As opiniões dos camaristas

\footnotetext{
${ }^{46}$ Veridiana da Silva Prado era matriarca de um dos clãs mais prósperos na virada do século XX em São Paulo, tendo como maior destaque o seu filho, Antônio da Silva Prado, que fora conselheiro do Império e Prefeito de São Paulo durante treze anos. Cf. HOMEM, 1980.

${ }^{47}$ Joaquim Eugenio de Lima propôs duas regulamentações para a Avenida Paulista, assim como Burchard e Nothmann fizeram em sua área: a proibição da passagem das reses por sua Avenida, consolidada com a Lei 100/1894, e a obrigatoriedade de seus recuos mínimos frontais de dez metros, consolidada na Lei $111 / 1894$.
} 
dividiram-se e o pagamento ficou suspenso por quase dois anos, quando se concluiu por realizá-lo ${ }^{48}$.

O projeto da Avenida Circular não prospera; contudo, os ganhos simbólicos da obra não tardam a chegar. Já no ano seguinte a Itatiaia começava a chamar a atenção dos afortunados da cidade, como vemos na visita prestada ao Boulevard por Alfredo Moreira Pinto, que a celebrou, em detrimento da até então predominante Avenida Burchard, como a "mais bonita por sua largura e extensão"49.

Mesmo que cortejada pelo geógrafo, à altura a paisagem da Avenida ainda era incipiente. À semelhança de outras expansões da cidade à época, sua ocupação deu-se em ritmo lento e gradual. Sendo assim, para entender as primeiras décadas da Avenida e de seus arredores, a contrapelo da imagem estática construída por Maria Cecília Naclério Homem (1980), na qual o loteamento emerge instantaneamente em seu apogeu, é necessário analisá-la sob a perspectiva de uma via em processo de consolidação. Ou seja, uma Avenida com paisagem instável e em constante mutação, composta por intervalos edificados e baldios, arruamentos transversais em paulatina expansão, alguns pavimentados, outros em terra crua, e que até meados da década de 1920 demarcava um dos confins da cidade, pois até então o plano do Pacaembú ficara apenas no papel (FIG. 6-10).

A ocupação do Boulevard teve início com a construção de algumas residências na Avenida Burchard e na Rua Maranhão, executadas por ingleses e norte-americanos de alta renda, seguindo a toada exclusivista dos empreendedores. Equiparavam-se aos modos requintados da contígua Vila Maria, residência de Veridiana da Silva Prado:

\footnotetext{
${ }^{48}$ Esse caso em específico demonstra os tênues limites entre o público e o privado na definição do que eram os "melhoramentos" urbanos, como já apontado por CERASOLI, 2004; SIMONI, 2002 e BRITO, 2000. Ao longo de 1899, ocorrem diversos debates na Câmara em relação a se Burchard deveria ou não ser remunerado por ter realizado tal obra, tendo em vista que ela não lhe fora requisitada pela municipalidade, mas fora executada pelo próprio Burchard, que somente depois recorrera à Câmara afirmando que havia realizado um "melhoramento" e que, por isso, devia ter o custo das obras abatido pelo poder público. Ver Atas da Câmara da Cidade de São Paulo, 1899, vol. 84, p. 135-141. O pedido para a proibição da passagem de gado foi realizado em 1891. Ver Atas da Câmara da Cidade de São Paulo, 1891, vol. 77 .

${ }^{49}$ PINTO, Alfredo Moreira. Correio Paulistano, "Boulevard Burchard”, 16 abr. 1898 - Dois anos depois, esse texto compõe seu livro posterior, intitulado A cidade de São Paulo em 1900, lançado pela primeira vez no ano a que remete o título. PINTO, Alfredo Moreira. A cidade de São Paulo em 1900. São Paulo: Governo do Estado de São Paulo, 1979.
} 
isoladas no meio de lote de grandes proporções, cercadas por jardins e gradil, com arquitetura suntuosa e de moderna construção, a exemplo das Residências de Franz Müller (1895), a do próprio Burchard (1897) e a do arquiteto Maximilian Hehl $(1897)^{50}$ (FIG. 11).

Contudo, com o primeiro prolongamento em direção à Paulista, no alto da festejada Rua Itatiaia, entre a Rua Goiás e a Avenida Municipal ${ }^{51}$, iniciava-se uma ocupação antípoda. De acordo com os pedidos de obras encontrados no Arquivo Histórico Municipal, entre 1896 e 1897, ali foram construídas trinta edificações, sendo uma destinada ao funcionamento de uma funilaria e o resto, ao uso residencial, algumas com espaço compartido para armazém ${ }^{52}$. Tratava-se, nos dizeres da época, de “casas operárias", construções em lote estreito, alinhadas à via e às laterais, com organização de frente-fundos, quatro cômodos (“sala”, dois "quartos” e cozinha), uma pequena área de fundo e geralmente um casebre separado, ou anexado à cozinha, para a latrina ${ }^{53}$.

O acesso ao solo distinto pelos empreendedores de menor poderio foi impulsionado pela localização do topo da Avenida, conformado por um entrelaçamento de contradições. Ali, as máculas do sanitarismo (Cemitério e Hospital de Isolamento) e o apartamento dos bondes, que chegavam apenas até a Avenida Burchard pela Rua D. Veridiana, chocavam-se com as promessas da Avenida Circular e as benesses simbólicas e materiais de Higienópolis e da Avenida Paulista. Diante da algazarra de valores, ao realizarem o prolongamento de 1896, Nothmann e Burchard, por falta de verba ou desconfiança quanto à sua rentabilidade, não dotam a região com esgoto e luz, destacando-a do elevado padrão do Boulevard, bem como diminuindo significativamente seu valor venal ${ }^{54}$. Movidos antes por obter lucros rapidamente do

\footnotetext{
${ }^{50}$ HOMEM, 1980, p. 80-82.

${ }^{51}$ Atual Avenida Dr. Arnaldo.

${ }^{52}$ Levantamento realizado nas caixas e encadernados contidos no Fundo de Obras Privadas do AHMSP.

${ }^{53}$ Os nomes dos cômodos foram colocados entre aspas, pois, como observa Lemos (1999), geralmente as alcunhas de atividades específicas figuravam nos desenhos apenas para facilitar a aprovação, pois no cotidiano das casas de baixa renda raramente a estrita especialização das áreas era praticada.

${ }^{54}$ Assim o atesta a Indicação n. 64, de 1905, em que diz o vereador Candido Motta: "atendendo a que a rua Itatyaia, entre a rua Maceió e a Avenida Paulista, não tem luz nem esgoto, nem guias para os passeios; atendendo a que as águas pluviais não têm escoamento porque ficam estagnadas no meio da rua durante
} 
que por efetivamente garantir a exclusividade da região, os próprios loteadores acabaram por adotar uma postura ambivalente em relação à Itatiaia, promovendo uma ocupação elitista em sua parte baixa e outra, menos controlada, em sua fração mais elevada.

O valor das terras de toda a Avenida foi concomitantemente abalado por externalidades, que nos ajudam a compreender ainda mais o comportamento hesitante dos alsacianos. Diferentemente do pressuposto no esquema de crescente linearidade, considerado em algumas leituras esquemáticas sobre o mercado de terras e imóveis de São Paulo, ao menos entre 1890 e 1910 esse ramo teve grande oscilação de preços e rentabilidade $^{55}$. Em 1893, por exemplo, o mercado imobiliário passou por um abrupto declínio em decorrência do excesso de loteamentos produzidos no fervor do Encilhamento, que acarretara também um agudo desequilíbrio fiscal. Crise agravada ainda pelo cenário nacional, que nos anos seguintes passou a sofrer com as repentinas baixas no preço do café no mercado internacional, que teve seu primeiro ciclo entre 1898 e 1906. Uma baixa prolongada dos preços repercutia na ampliação de oportunidades para os consumidores remediados, mesmo nos loteamentos mais refinados, como o Boulevard, ainda mais nas partes sem infraestrutura da Itatiaia. Brechas econômicas que, provavelmente também em outras áreas da cidade, colocavam abaixo a aparentemente inviolável muralha dos preços ${ }^{56}$.

Das residências construídas no alto da Itatiaia, algumas foram erguidas em conjuntos geminados de duas ou três unidades, às vezes para residência própria e

muito tempo, com grave prejuízo da saúde publica; atendendo a que o estagnamento das águas forma um grande atoleiro naquele ponto, embaraçando a passagem de veículos; atendendo a que todos esses fatos têm concorrido para o aparecimento de febres intermitentes nos moradores daquela rua; indico que o sr. Prefeito mande fazer os reparos de que necessite a referida rua bem assim requisite ao governos do estado a colocação ali de combustores de gás”. Anais da Câmara Municipal de São Paulo, 1905, p. 60.

${ }^{55}$ Dentre os autores que estudaram o processo de consolidação da cidade passando por Higienópolis, como ROLNIK (1997) e GROSTEIN (1897), a maioria aplica uma norma constante ao mercado de terras, como se este estivesse em constante crescimento desde fins do século XIX até meados do XX. Obviamente essa percepção as leva a crer que os preços iniciais dos terrenos em Higienópolis eram altos e só tenderam a aumentar, donde encontram explicação para a homogeneidade que projetam sobre o bairro, que debateremos mais detidamente adiante. ROLNIK, Raquel. A cidade e a lei. São Paulo: Studio Nobel, 1997; GROSTEIN, Marta Dora. A cidade clandestina: os ritos e os mitos. São Paulo: Faculdade de Arquitetura e Urbanismo da Universidade de São Paulo (Tese de Doutorado), 1987.

${ }^{56}$ CANO, Wilson. Raízes da concentração industrial em São Paulo. (Tese de doutorado) - IFCH UNICAMP, Campinas, 1990, p. 122; SIMONI, 2002, p. 132 e 146; BRITO, 2000, p. 103-107. 
aluguel, outras apenas para negócios. Grande parte de seus proprietários eram de origem italiana, provavelmente recém-chegados à cidade, e que encontraram no mercado imobiliário uma boa oportunidade para estabelecer-se na capital, além de um trampolim para dar início à almejada ascensão na escala social ${ }^{57}$. Esse foi o caso de Cosmo Tortola e Angelo Barrigelo, tendo ambos pedido licença, o primeiro em 1896 e o outro, em 1897, para a construção de três casas, sendo apenas duas geminadas. Como eles, foram tantos outros, como Alfredo Pacheco, Antonio Pignon, Erneche Tuglia, Giovanni Federico, Tomaso Rusa, Felix Parula, Angiolo Monaco, Daniel Kruss, Martino Raucci, Alessio Pretti, Augusto Pried, Hermano Kuner, Francisco Oliva, Salvador Porma, José Crechiaro, Samuel Baldenetti, Luis Ambrósio, José de Niso Luigi Vetuglia e Domenico Monica ${ }^{58}$ (FIG. 13-22).

Se alguns, com crédito na praça ou por frutos próprios, faziam negócio com moderado rendimento, as casas de porta e janela também foram estratégia empregada como um meio de estabilização econômica pelos que encontravam na residência própria uma possibilidade de livrar-se do peso do aluguel. Posteriormente, a economia permitia o acúmulo de certa renda, que poderia ser convertida para o conforto cotidiano ou para pequenos negócios. Além do mais, ser proprietário constituía status social, tanto no trato do dia a dia, como na relação com bancos, credores e com a própria máquina estatal ${ }^{59}$. A propriedade poderia ser hipotecada, servindo o crédito como primeiro passo para uma tentativa de ascensão que, no contexto de grande demanda por moradias, era muitas vezes realizada através da construção de uma segunda casa, dessa vez para aluguel ${ }^{60}$.

\footnotetext{
${ }^{57}$ Casos semelhantes podem ser encontrados no minucioso estudo de Maria Luisa Ferreira de Oliveira sobre os setores remediados de São Paulo entre 1850-1900. Cf. OLIVEIRA, Maria Luisa Ferreira de. Entre a casa e o armazém. Relações sociais e experiência de urbanização: São Paulo, 1850-1900. São Paulo: Ed. Alameda, 2005.

${ }^{58}$ Fundo de Obras Privadas do AHMSP, vol. 118, p. 114-140; vol. 162, p. 133-138 e 140-176; vol. 239, p. 81-83; vol. 357 , p. $97-143$

${ }^{59}$ Ser proprietário era um status social tão respeitado quanto ter uma ocupação, como observa Borin (2014) ao analisar os processos-crime da Barra Funda em período semelhante ao nosso. BORIN, Monique Félix. Barra Funda e o fazer da cidade: experiências da urbanização em São Paulo (1890-1920). Dissertação (Mestrado) - FFLCH-USP, 2014.

${ }^{60}$ Esse era o caso dos pequenos investidores do mercado imobiliário da época, largamente descritos por Luciana Gennari (2005) e Maria Luiza de Oliveira (2005). Apesar de ter sido regulamentada apenas em 1900, há fortes indícios de que a hipoteca de imóveis urbanos foi praticada desde ao menos a década
} 
Esse foi o caso de Joaquim Francisco de Lima, que construiu uma casa na Avenida em 1896. No ano anterior, havia sido transferido do Serviço Sanitário para trabalhar como porteiro do Hospital de Isolamento, sendo a casa provavelmente para uso próprio. Em 1903, pediu licença para construir, ao lado da sua, outra casa junto com um armazém, provavelmente buscando um complemento para seu pequeno vencimento de porteiro. Em 1907, foi demitido do hospital, servindo-lhe os imóveis, provavelmente, como um arrimo enquanto buscava por um novo emprego (FIG. 22).

Mesmo tendo-lhes rendido certos dividendos, dois anos após seu prolongamento até a Paulista, os loteadores tentarão criar restrições à ambígua ocupação que se desenrolava na Itatiaia. Assim, em 1897, procuram enquadrar sua totalidade no projeto exclusivista do Boulevard através de requerimento de Burchard à Câmara, que propunha que fossem tornados obrigatórios os recuos frontais para todas as construções erguidas em toda a extensão da Itatiaia e da Higienópolis. A parte superior da Itatiaia, assim, mudava de lugar no espectro dos interesses da dupla. Antes céticos com o potencial da região, talvez agora percebessem que, após a ligação com a Paulista e as Palmeiras, aquele trecho poderia ser valorizado ao incorporar-se a uma via capaz de articular os principais loteamentos onde se situavam os mais abastados Avenida Paulista, Higienópolis, Campos Elíseos e Barra Funda -, além de funcionar, como a Higienópolis, como uma magistral porta de entrada e cartão-postal para o Boulevard.

Longe de serem idealistas, guiavam-se pelo faro de mercado. Por isso, optaram por restringir a ocupação apenas em duas vias, e não no loteamento inteiro. Afinal, Nothmann vivenciara na própria pele a frustração de tentar promover a ocupação exclusiva dos Campos Elíseos, e provavelmente percebera que o mercado de terras para as elites era não somente restrito, mas também altamente competitivo ${ }^{61}$. Sendo assim, para constituir uma mercadoria exclusiva talvez fosse mais viável centrar-se em poucas vias, como o fizera Joaquim Eugenio de Lima, deixando o resto do loteamento

anterior. Cf. BRITO, Monica Silveira. Modernização e tradição: urbanização, propriedade de terra e crédito hipotecário em São Paulo na segunda metade do século XIX. São Paulo: FFLCH - USP (Tese de doutorado), 2006, p. 102.

${ }^{61}$ MARINS, 2011, p. 218-223. 
para negociações mais flexíveis. Vale notar que, para além do aspecto pragmático, a medida também guardava um cunho simbólico, no qual os negociantes tentavam inserir suas avenidas no circuito de suntuosas vias das grandes capitais do Norte, como já o vinha fazendo a Avenida Paulista, que procurava integrar-se ao rol dos elegantes passeios da Quinta Avenida de Nova Iorque e dos boulevards do VIIéme e XVIéme arrondissements de Paris, bem como das capitais vizinhas, a exemplo das avenidas Alvear, Libertad, de Mayo e Belgrano, em Buenos Aires ${ }^{62}$.

Cinco meses depois do requerimento de Burchard, em março daquele ano, o vereador Pedro Augusto Gomes Cardim, à altura Intendente de Obras Municipais, apresentou projeto de lei não apenas acatando a proposta dos negociantes, mas tornando-a ainda mais estrita, incluindo a obrigatoriedade de recuos laterais de dois metros. O interesse de Cardim na região não era fortuito, uma vez que, como veremos, o intendente era um grande entusiasta da Avenida Circular. Já em junho, o projeto foi colocado em votação e, sem pareceres e sem debates, foi aprovado, convertendo-se na Lei 355/1898.

$\mathrm{Na}$ materialidade proposta pela lei - casas recuadas e ladeadas por jardins -, como já assinalado por Rolnik, estava implícito um argumento social subjacente ao interesse estético $^{63}$. Um esclarecedor embate envolvendo dois vereadores, alguns anos depois, ajuda a evidenciar seu conteúdo. Em 1914, Alcântara Machado apresenta projeto de lei para estabelecer recuos mínimos de dez metros nas novas construções da Avenida do Jardim da Aclimação. Em sua defesa, cita como exemplo a legislação que regulava os recuos das avenidas Angélica, Paulista, Água Branca e Higienópolis. Após louvar seu resultado estético, argumenta que eram localidades “onde por enquanto só existem casas nobres e de feitio elegante. Seria pena que por falta de uma disposição apropriada, viessem a conspurcá-lo casebres e vendolas”. Responde-lhe o vereador Baptista da Costa que, dado o seu radicalismo, “[...] era melhor apresentar um projeto proibindo a construção das casas modestas, enfim, das casas para operários”,

\footnotetext{
${ }^{62}$ MARINS, Paulo Cesar Garcez. La avenida Paulista de la Belle Époque: elites en disputa. In: GORELIK, Adrián e PEIXOTO, Fernanda Arêas (org.). Ciudades latino-americanas como arenas culturales. Buenos Aires: Siglo XXI, 2016, posições 922 a 955 (versão Kindle).

${ }^{63}$ ROLNIK, 1997, p. 46.
} 
argumentando que o radicalismo do vereador ia "ao ponto de não admitir que a gente pobre tenha casa para habitar". Machado replica, dizendo que "ninguém proíbe que a gente pobre tenha casa para habitar... O que indiretamente se proíbe, é que se levantem casinholas, em certos pontos da cidade".

A noção de "elegância" mobilizada por Machado, longe de explicitar um conceito universal de beleza, remetia a um gosto específico, ligado ao repertório estético das classes elevadas, como já notado, com grande enraizamento nos faubourgs parisienses. Esse ideal possuía uma materialidade característica que limitava hábitos e gestos ao espectro dos costumes cultivados pelos privilegiados. Sendo assim, apesar de sua aparente universalidade, a beleza e a feiura eram mobilizadas como argumentos de exclusão, uma vez que o conspurcado, aos olhos do vereador, coincidia precisamente com a materialidade que ancorava o cotidiano dos setores baixos, cujos costumes e possibilidades financeiras dificilmente permitiriam sua incorporação ao ideal proposto. O argumento exclusivista de Machado ecoa na lei de 1898, coadunando com os patentes interesses de Burchard e Cardim, que se valiam do poder municipal para avalizar o sucesso comercial do Boulevard e garantir o poder simbólico da Avenida Circular, que, para além do prazer estético às elites caminhantes, pretendia expressar a "civilidade" e pujança da capital do café.

Façamos aqui um breve parêntese para melhor explicar o funcionamento desse artifício simbólico, ainda por muitas vezes mal compreendido em nossa historiografia ${ }^{64}$. Como vimos na introdução, o uso metafórico da cidade fazia parte de uma estratégia empregada em âmbito nacional pelos primeiros presidentes paulistas -

\footnotetext{
${ }^{64}$ Uma exposição clara da posição historiográfica a que me refiro pode ser encontrada no balanço realizado por Josianne Cerasoli e Marisa Carpintério, que criticam as interpretações da modernização das cidades brasileiras nas quais as escolhas dos agentes locais são obliteradas pelas explicações generalistas que, a partir de referenciais exclusivamente externos ao contexto local, explicam o processo de modernização como se fosse o resultado mecânico de uma adesão inerte de suas populações aos valores e preceitos gestados na cultura burguesa europeia. Nessas explicações: "as dinâmicas plurais ligadas a processos complexos de distinção e produção de significados - sociais, estéticos, políticos - aparecem, assim, envoltas por valores exteriores e anteriores a eles. Estruturam-se as explicações sobre as escolhas e as formas adotadas (perfis arquitetônicos das edificações, dimensões e distribuição de ruas, quadras, recuos, etc.) [...] em atributos diretos desses fatores externos, como se prescindissem das situações históricas estudadas e prescindissem da cidade para serem compreendidas como escolhas." CARPINTERIO, Marisa Varanda Teixeira e CERASOLI, Josianne Francia. A cidade como história. História: Questões \& Debates, Curitiba, n.50, jan./jun. 2009. Editora UFPR, p. 93-94.
} 
Prudente de Morais, Campos Salles e Rodrigues Alves - para convencer o mundo civilizado de que o país, e mais especificamente o Estado de São Paulo, consistiam em cenários prósperos para o investimento de recursos, sem os quais a economia cafeeira tornava-se insustentável: a mão de obra imigrante, empréstimos para a expansão das lavouras e controle do preço das sacas no mercado internacional e recursos técnicos de infraestrutura para colheita e escoamento da produção ${ }^{65}$. No âmbito nacional, o fortalecimento simbólico de São Paulo alinhava-se também com o intento de suas elites políticas e econômicas em firmarem seu projeto hegemônico, servindo as imagens da capital como uma forma de suplantar, por meio da exibição de seu progresso, as outras porções da Federação.

Faziam parte dessa ampla estratégia a escolha do Ecletismo como linguagem predominante para os edifícios públicos, bem como a referência explícita aos planos urbanos europeus ${ }^{66}$. Como união supranacional de estilos historicistas, o Ecletismo operava como uma potente face estética dos valores de interdependência e solidariedade imaginados pelos entusiastas do capitalismo internacional, que davam àquela desenfreada e conturbada modernização a serena alcunha de belle époque. Representava o abraço final de todas as nações, do qual nem São Paulo, nem o Brasil queriam ficar de fora, apressando-se em alcançar os confrades do norte ${ }^{67}$.

Para admirar sua potência, basta observar o amplo trânsito estético e modelar da Ópera de Paris (1874), construída por Charles Garnier, e referência central para os Teatros Municipais de São Paulo (1911) e do Rio de Janeiro (1909). Essa mesma obra serviu de modelo, na Polônia, para o Teatro Juliusz Słowacki (1893) e o Warsaw Philarmonic Halll (c. 1901); na Ucrânia, para a Ópera Nacional (1901) e o Teatro Lviv (1900); nos Estados Unidos, para o bloco Thomas Jefferson da Biblioteca do Congresso (1897); no Vietnam, para a Casa de Ópera Hanoi (1901); na própria França, para a Ópera de Reims (1873); além da Casa de Ópera de Frankfurt (1880), entre outras. Isso sem mencionar as obras que o próprio Garnier realizou no interior da

\footnotetext{
${ }^{65}$ SEVCENKO, 2010, p. 55-75 e SIMONI, 2002, p.157-164.

${ }^{66}$ CAMPOS NETO, 2000, p. 187-190.

${ }^{67}$ Cf. COSTA, Angela Marques da e SCHWARTZ, Lilia Moritz. 1890-1914: no tempo das certezas. São Paulo: Companhia das Letras, 2000.
} 
França, como o Casino de Vittel (1887), e no exterior, como a Ópera de Montecarlo, em Mônaco $(1870)^{68}$.

Ao construir um teatro baseado na obra de Garnier, a municipalidade paulistana pretendia muito mais do que satisfazer a veleidade de suas elites ou copiar frivolamente a paisagem de Paris. Tencionava, assim como tantas outras capitais do próprio hemisfério norte, estabelecer potentes enunciados analógicos entre a capital paulista e o centro irradiador cultural da "civilização". A execução de uma obra desse porte, assim como outras magnânimas transformações no espaço urbano - como a constituição de formosas e elegantes Avenidas -, anunciavam muito mais do que o domínio da alta cultura, mas principalmente a solidez das instituições públicas e a pujança da economia local. Estes eram dois dados fundamentais para a conquista da confiança internacional que sustentava a economia cafeeira. Longe da unanimidade, tratava-se de um projeto de desenvolvimento que galgava suntuosas vantagens para determinados setores econômicos e grandes entraves para outros, encontrando resistência e divergência nos mais diversos espectros da população, inclusive dentro das próprias elites ${ }^{69}$. A preponderância da forma simbólica da cidade em relação a seu uso cotidiano também encontrara cisões entre os especialistas atuantes na conformação dos espaços urbanos ${ }^{70}$. Contudo, apesar das tensões e disputas, que acompanharemos mais de perto no segundo capítulo, foi um projeto preponderante nas ações da municipalidade até a decadência dessa utopia cosmopolita, marcada a sangue pela violenta cisão das nações europeias na Primeira Guerra Mundial.

Após esse breve desvio, voltemos à trajetória de nossa Avenida.

\footnotetext{
${ }^{68}$ Devo essa observação à perspicaz conferência de Paulo Garcez, em que apresentou parte dessas referências em palestra proferida no Teatro Municipal de São Paulo durante a Jornada do Patrimônio, organizada pela Prefeitura Municipal de São Paulo em 2016.

${ }^{69}$ CAMPOS NETO, 2000, p. 281-285.

${ }^{70}$ Candido Malta trata das trajetórias de Victor Freire e Saturnino de Brito, que, no âmbito do planejamento urbano, procuraram elaborar uma via especificamente local de intervenção em detrimento da utilização de modelos cosmopolitas. CAMPOS NETO, 2000, p. 187-190.
} 


\section{O sacolejo do Paraíso: disputas em torno de uma lei}

Em A cidade e a lei, Raquel Rolnik foi taxativa quanto aos efeitos da Lei 355, descrevendo-a como “o milagre de desenhar uma muralha invisível” entre os pobres e as elites ${ }^{71}$. Uma leitura embasada tanto pelo trabalho anterior de Marta Dora Grostein $^{72}$, que aponta o mesmo caminho interpretativo, como pela visão homogeneizante de Higienópolis perpetuada principalmente por Maria Cecília Naclério Homem ${ }^{73}$. Não restam dúvidas a respeito do desejo de apartamento das elites, contudo, Rolnik exagerou sua efetividade. A precipitada vitória que dá aos abastados parece guiada por três premissas. Primeiramente, pela concepção dos agentes imobiliários como um grupo homogêneo e orquestrado, conformando uma atmosfera consensual em torno da produção urbana, com poucas fissuras para a aparição de

\footnotetext{
${ }^{71}$ ROLNIK, 1997, p. 46.

${ }^{72}$ GROSTEIN, 1987, p. 69-74.

${ }^{73}$ Talvez o primeiro historiador a dar contundência a essa imagem homogênea de Higienópolis tenha sido um de seus mais célebres moradores: Caio Prado Jr. Em Nova contribuição para o estudo geográfico da cidade de São Paulo (1941), reiterando suas hipóteses apresentadas em O fator geográfico na formação e no desenvolvimento da cidade de São Paulo (1936), o autor nos relata o crescimento urbano da cidade na virada do século: "Em princípios do século atual, os bairros residenciais lançam-se decididamente pelo flanco de maciço, subindo-lhe as encostas à procura de terrenos mais altos e saudáveis; é a vez de Higienópolis, que será o bairro da aristocracia paulista das fortunas saídas do café" (PRADO JR., 1941, 210).

Caio Prado lê a formação do espaço urbano paulistano como um processo de radical fratura e segregação. O vetor de crescimento a leste do Centro é ocupado apenas por "operários", enquanto o vetor oeste é habitado exclusivamente pelas "elites". Nos anos seguintes, essas hipóteses foram ratificadas por Pierre Monbeig, que em La croissance de la ville de São Paulo (1953) escreveu que Higienopólis era "o bastião urbano dos fazendeiros" (1953, p. 48), e por Richard Morse em De comunidade à metrópole: biografia de São Paulo (1954). A interlocução desses três trabalhos não é apenas evidente pela repetição das ideias, mas também pela rede intelectual que esses três autores compartilhavam. Monbeig escreveu um ensaio introdutório para a segunda edição do livro de Morse, Morse declarou em entrevistas que foi leitor assíduo de Caio Prado Jr. (CASTRO, 2013) e este último, por fim, declarou ser amigo de longa data de Monbeig no prefácio que escreveu a um de seus últimos livros sobre o Brasil (AB'SABER, 1994). É sobre essa base bibliográfica que emerge a interpretação de Maria Cecília Naclério Homem, que não só tomou as obras dos três como referência bibliográfica, mas também possivelmente manteve relações com todos, pois à época em que escreveu seu livro, já era esposa de Caio Prado. PRADO JR. Caio. Nova contribuição para o estudo geográfico da cidade de São Paulo. Estudos Brasileiros, ano III, vol. 7, no 19-21, Rio de Janeiro, 1941. MORSE, Richard. De comunidade a metrópole: biografia de São Paulo. São Paulo: Comissão do IV Centenário de São Paulo, 1954; AB' SABER, Aziz. "Pierre Monbeig: a herança intelectual de um geógrafo". Estudos Avançados, 1994, São Paulo, vol.8, n.22, pp. 221-232; CASTRO, Ana Claudia Scaglione Veiga de. Um americano na metrópole (latino-americana): Richard Morse e a história cultural urbana de São Paulo, 1947-1970. Tese (Doutorado), FAU-USP, São Paulo, 2013; MONBEIG, Pierre. La croissance de la ville de São Paulo (1953). In: Revue de Geographie Alpine, 1953 e HOMEM, 1980.
} 
embates e discordâncias. A ideia de hegemonia das elites é tamanha que, ao deparar-se com a subsequente revogação dos recuos da Itatiaia em 1902, procura uma explicação para o contradito exclusivamente dentro do universo dos abastados.

Sem apresentar dados documentais para corroborar suas hipóteses, a autora dá a entender que as casas geminadas construídas em Higienópolis eram realizadas pelos próprios abastados, que as destinavam frequentemente aos "ramos menos prósperos da família"74. Para as que eram comercializadas, argumenta que os moradores mais afortunados da região as erguiam "nos limites daqueles bairros exclusivos", criando uma espécie de anel de classe média em torno de um centro mais exclusivo. Observando o SARA-Brasil, pude perceber que a ocupação do bairro esteve longe desse ideal modelar de organização, sendo muito mais heterogênea, descontínua e intrincada. Assim, como veremos, também foram mais diversos os agentes atuantes na região (FIG. 25).

Seguindo o argumento da autora, é com base nesses pressupostos que ela explica a derrubada da lei de recuos em 1902: uma querela entre as próprias elites, que se dividiam entre os que queriam estrita exclusividade e os que queriam diversificar seus negócios e agrupar seus ramos menos favorecidos ao seu redor. Não nego que tais disputas tenham ocorrido no bairro, porém, de acordo com levantamento realizado junto ao Fundo de Obras Privadas do Arquivo Municipal, elas não podem ser explicativas dos embates envolvidos em torno da lei de recuos, simplesmente porque, até 1904, não houve pedidos de obra de palacetes (com exceção da casa de Angélica de Sousa Queiroz, construída em sua chácara, que depois foi atravessada pela via), ou seja, não haviam abastados habitando a Itatiaia. Tampouco houve ali pedidos para casas de classe média até 1905, quando ocorre apenas uma única requisição. Alias, ao

\footnotetext{
${ }^{74}$ Aliás, pelo contrário, é interessante notar que mesmo em sua atmosfera celebratória e homogeneizante, Maria Cecília Naclério Homem, como que en passant, comenta sobre a existência de casas operárias no topo da Itatiaia (HOMEM, 1980, p. 98-100) sem nunca mencionar as casas de classe média supostas por Rolnik. O conhecimento de Naclério dessas residências adveio das mesmas fontes consultadas neste trabalho - pedidos de obra do Fundo de Obras Privadas do Arquivo Histórico Municipal -, contudo, talvez por conta de seu referencial teórico e interpretativo e das questões que moviam seu trabalho, ela menciona tais pedidos como eventos episódicos, mas não os considera relevantes para repensar a formação e ocupação do bairro. Os comentários de Rolnik sobre a revogação da Lei 355/1898 estão nas páginas 111-112 de seu livro (ROLNIK, 1997).
} 
contrário do que aponta Rolnik, as casas de classe média não se disseminaram com a derrubada da lei de recuos, mas sim com a sua retomada em 1907, como podemos ver claramente nas Tabelas 1 e 2, dispostas adiante. Até então predominava o interesse em construir "casas operárias", obras ali empreendidas não pelos moradores de palacetes, mas por pequenos proprietários que, como veremos, foram os mais prováveis agentes promotores da revogação de 1902.

Daí o malogro da segunda premissa adotada pela autora: Rolnik superestima o poder legislativo das elites, ressaltando suas vitórias e ignorando suas derrotas, desconsiderando outros grupos que também alçavam sua representatividade na Câmara Municipal, disputando a arena pública em defesa de seus próprios interesses ${ }^{75}$. Esse modelo, que projeta um harmônico elitismo na produção da legislação e do espaço, como veremos, se mostra insuficiente para bem interpretar a história da referida lei, bem como do "fazer-se" da cidade, no qual as normatizações do espaço urbano configuraram, mesmo que com poderes desiguais entre as diferentes partes, verdadeiros campos de tensão e disputa.

Por fim, Rolnik toma a Câmara Municipal como uma oligarquia perfeita, onde não havia espaço para o interesse público diante da imperante ambição privada. Apesar da evidente força do benefício próprio, frequentemente o interesse coletivo também atravessava os conflitos decisórios da Câmara. Assim o vimos no debate de Alcântara Machado e Baptista da Costa, quando o segundo criticou o radicalismo exclusivista do primeiro, e o veremos algumas outras vezes no proceder do debate pela lei de recuos. Como o "fazer-se" da cidade no qual estavam embrenhados, os camaristas e seus relacionamentos também eram contraditórios, tensos e ambivalentes.

A convergência desses três pressupostos levou Rolnik a descrever a Lei 355 como um muro. Já apontamos alguns de seus problemas, agora passemos detalhadamente à análise do que nos motiva a perceber que, apesar de enfático na redação da lei, na

\footnotetext{
${ }^{75}$ Josianne Cerasoli (2004), ao pesquisar diversas documentações da Câmara Municipal de São Paulo, mostra o oposto, ou seja, que a Câmara era uma arena de disputas, na qual participavam dos mais aos menos abastados da escala social. É a partir dessa interpretação que articulamos as críticas ao modelo monolítico e exclusivista do poder municipal projetado por Rolnik, e é a partir dessas que desenvolvemos as reflexões a seguir sobre a tortuosa trajetória da lei de recuos da Avenida Angélica.
} 
prática esse muro não foi nem tão robusto, nem tão pleno, nem tão alto como pretendera a autora. Como há pouco mencionado, apenas três anos após sua promulgação, a Lei 355 foi severamente contestada na Câmara Municipal. No dia primeiro de agosto de 1901, Serafim Leme da Silva apresentou um projeto de revogação, apenas para a Avenida Itatiaia, dos estabelecidos em 1898. O choque de interesses que motivava o intento foi explicitado em parecer redigido pela Comissão de Justiça da Câmara ${ }^{76}$ no mês seguinte. Sobre a Lei 355, os comissionários, apoiando o projeto de Leme, apontaram que a referida lei "lhe[s] parece, em sua inteira disposição, um tanto restritiva do direito de propriedade, que a Constituição [...] garante em toda sua plenitude". Por outro lado, assinalaram que a lei "foi inspirada pelo desejo de embelezar o arrabalde a que se refere e já trouxe, de fato, algum proveito nesse sentido"77. A divergência manifestada no próprio relatório se desenrola em debates ao longo de quatro sessões, que se encerram com a aprovação da medida em junho do ano seguinte, promulgada na Lei 587/1902.

A revogação evidencia a insatisfação de alguns proprietários da Avenida Itatiaia com os excessos do esquema sanitarista e embelezador, vigente nas normas de Burchard e Cardim, na restrição ao usufruto de suas propriedades. Diferentemente do que acontece na Higienópolis, que, apesar de constar na mesma Lei e restringir os mesmos direitos, não tem a anulação de seus recuos sequer mencionada. As trajetórias distintas da mesma Lei evidenciam que os agentes atuantes na Itatiaia possuíam interesses conflituosos entre si, ao contrário dos proprietários da Higienópolis que, ao menos nesse aspecto, pareciam confluir em seus anseios. Isso revela que, em um

\footnotetext{
${ }^{76}$ Infelizmente não foi possível estudar as trajetórias e biografias de todos os vereadores que se envolveram no processo. Contudo, para interesse futuro e para apreendermos a complexidade do jogo, no qual muitos vereadores mudavam dinamicamente de posição, deixaremos assinalados quais eram os participantes das comissões que assinavam os pareceres à altura de cada evento. Neste caso, o parecer foi assinado por Pedro Vicente e João Antônio Julião. Atas da Câmara da Cidade de São Paulo, vol. 86, 1901. ${ }^{77} \mathrm{O}$ conflito entre ações urbanísticas e o livre usufruto do direito de propriedade não é específico dessa lei, mas parece ter sido assunto comum na produção normativa do espaço urbano da época. Contudo, no caso da Itatiaia, ele só foi levado em consideração com a manifestação de contraditórios. Em 1894, quando Joaquim Eugenio de Lima fez requisição semelhante para a Avenida Paulista, Pedro Vicente, na condição de parecerista, defendeu que no caso da obrigatoriedade de recuos deveria ser forçosa a indenização aos proprietários, uma vez que teriam seus direitos privados agravados para o benefício da coletividade. Contudo, observando que a maior parte dos terrenos ainda pertencia ao loteador, aprova a proposta de lei, com o salvo-conduto de que todos os proprietários deveriam assinar um acordo concordando com as normas. Atas da Câmara da Cidade de São Paulo, 1894, vol. 79, p.147.
} 
mesmo bairro, coexistiam situações socioespaciais extremamente díspares, que geravam paisagens similares às relações que as materializavam: na Higienópolis, a encarnação de seu consenso no ritmo constante e pausado de seus casarões e jardins, na Angélica, a expressão do seu sacolejo em uma paisagem híbrida, instável e desorganizada $^{78}$.

Como observado há pouco, até o momento, a maioria das obras requisitadas na Avenida haviam sido para a construção de “casas operárias". A partir de 1898, ano seguinte à promulgação da Lei 355, os pedidos diminuem, chegando a seu ocaso em 1901, ano da proposta de Leme, quando não foi realizada nenhuma solicitação. Não à toa, no ano seguinte à aprovação da revogação, os pedidos de "casas operárias" voltam a crescer, somando seis em 1902, dezessete em 1903, três em 1904 e catorze em 1905. A predominância desses empreendedores na Avenida era tamanha que, nesse ínterim, apenas um pedido foi realizado para residências de médio padrão e nenhuma para palacetes ou casarões.

\begin{tabular}{|l|r|r|r|r|r|}
\hline Ano & BP & BMP & MP & MAP & A \\
\hline 1896 & 15 & 0 & 0 & 0 & 0 \\
\hline 1897 & 13 & 2 & 0 & 0 & 0 \\
\hline 1898 & 2 & 0 & 0 & 0 & 0 \\
\hline 1899 & 9 & 2 & 0 & 0 & 0 \\
\hline 1900 & 2 & 0 & 0 & 0 & 0 \\
\hline 1901 & 0 & 1 & 0 & 0 & 0 \\
\hline 1902 & 6 & 0 & 0 & 0 & 0 \\
\hline 1903 & 17 & 0 & 0 & 0 & 0 \\
\hline 1904 & 3 & 0 & 0 & 1 & 0 \\
\hline 1905 & 14 & 0 & 1 & 1 & 0 \\
\hline 1906 & 0 & 2 & 0 & 0 & 2 \\
\hline TOTAL & 81 & 7 & 1 & 2 & 2 \\
\hline
\end{tabular}

TABELA 1 - Pedidos de obra realizados entre 1896 e 1906 para a Rua Itatiaia e Avenida Angélica. As siglas correspondem a: (BP) baixo padrão; (BMP) baixo-médio padrão; (MP) médio padrão; (MAP) médio-alto padrão; (A) alto padrão. A diferenciação foi estabelecida a partir de critérios: (1) número de cômodos; (2) tamanho do terreno e posição da edificação; (3) sofisticação compositiva e decorativa; (4) tamanho do volume construído. Fonte: Fundo de Obras Privadas do AHMSP.

\footnotetext{
${ }^{78}$ Trataremos mais detidamente desse assunto nos capítulos seguintes, mas, para se ter uma breve imagem do contraste paisagístico a que nos referimos, cf. FIG. 63.
} 
Os planos desses inominados, contanto veementes, proprietários para a Avenida eram outros. A melhor realização de seus negócios dependia do máximo aproveitamento construtivo da terra e dos materiais. A "restrição ao direito de propriedade" imposta pela obrigatoriedade de recuos frontais e laterais infringia a ambos usufrutos, diminuindo a proporção de lucro por metro quadrado e diminuindo o fundo do lote, que comumente era preservado para um futuro empreendimento ${ }^{79}$. O disposto também impedia a geminação, estratégia construtiva correntemente empregada na época, através da qual os empreendedores viabilizavam consideráveis economias de material e de conexão de infraestrutura, além de otimizarem a ocupação da terra. Ademais, visavam clientes de baixa renda, para os quais a exclusividade ou a existência de jardins frontais ou maior conforto, por seu restrito poderio de consumo, raramente correspondiam a aumentos no aluguel.

A insatisfação dos construtores certamente era acirrada pela já mencionada crise econômica que assolava o país, que naqueles anos afetava drasticamente o principiante ramo da construção civil, bem como o mercado de terras. A modorra em que engrenava o setor também flagelava a municipalidade, que sofria pressões para resolver o imenso déficit habitacional da cidade ${ }^{80}$. Em tom de urgência, em 1900 aprova-se a Lei 498, isentando de impostos de viação e emolumentos os construtores de "casas operárias" e reiterando o padrão menos restritivo estabelecido em 1889 para essas edificações, permitindo maiores lucros em sua produção e locação. A norma era válida apenas para as áreas excluídas do perímetro urbano. Novamente demonstrando o dissenso interno à Câmara no que dizia respeito aos bairros exclusivos, toda a região de Higienópolis foi demarcada como passível de isenção e, portanto, áreas para as quais a Prefeitura direcionava esses esforços construtivos ${ }^{81}$.

Dentre os interessados em construir na Avenida, não se sabe ao certo quais estiveram diretamente envolvidos com o vereador Leme na revogação das disposições

\footnotetext{
${ }^{79}$ Cf. GENNARI, 2005.

${ }^{80}$ Cf. CAMPOS, Eudes. Casas e vilas operárias paulistanas: A situação da moradia da classe trabalhadora no final do Império. Informativo do Arquivo Histórico Municipal. São Paulo, jul/ago., ano 4, n. 19 (versão digital). Disponível em: http://www.arquiamigos.org.br/info/info19/i-estudos.htm (último acesso em fevereiro de 2017) e SIMONI, 2002.

${ }^{81}$ Lei ${ }^{\circ} .498$ de 14 de dezembro de 1900. Cf. SIMONI, 2002.
} 
de recuo. Quase nenhum deles consta nos registros eleitorais da época, muitos provavelmente pela origem estrangeira ou pela insuficiência de renda, confirmada pela dimensão modesta das construções, em maioria casas únicas ou em dupla geminada. Contudo, os membros das classes baixas e remediadas possuíam outras formas de defender seus interesses perante o Estado, recorrendo a cartas, contratos e abaixoassinados enviados às autoridades. Provavelmente, foi através desses recursos que os pequenos proprietários defenderam o mercado que lhes dava sustento, protegendo a manutenção de suas estratégias de ascensão e sobrevivência ${ }^{82}$.

Seria o caso, por exemplo, de Joaquim, porteiro do Hospital de Isolamento, que em 1903 ergueu casa de aluguel junto à sua na Avenida, ou Domenico Monica, que um ano após a revogação pede licença para erguer duas casas “operárias”, alinhadas à via e às laterais do lote, com tanque conjunto e duas cocheiras ao fundo. No ano seguinte, requisita licença para construir outras duas residências de baixo padrão geminadas às primeiras. Os quatro imóveis de Domenico certamente lhe proporcionaram bom rendimento, permitindo-lhe adquirir outro imóvel de baixo padrão, vizinho aos seus, que em 1913 foi reformado e transformado em uma residência mais ampla e confortável. No ano seguinte, ele fez o mesmo com um de seus antigos imóveis, provavelmente interessado em inserir-se em mercado locatício mais elevado ${ }^{83}$.

Dentre a maioria remediada, um abastado também pode ter se envolvido no fim da lei de recuos, somando à linha dos pequenos proprietários. Antônio Ferreira da Rosa, um ano após a revogação da Lei 355, requere a construção de uma cocheira em seu extenso terreno na Itatiaia, entre a Rua Jaguaribe e a Avenida Higienópolis. Dois anos depois, requisita no mesmo terreno a construção de nove casas para aluguel, construídas no alinhamento da via, e um palacete para morada própria, com frente não para a Angélica, mas para a Rua Jaguaribe. As residências do capitão não eram destinadas à baixa renda, possuindo cada uma entre seis e oito cômodos, fachadas singelamente ornamentadas e fundos $\operatorname{amplos}^{84}$. Mas nem por isso deixaram de ser

\footnotetext{
${ }^{82}$ Para além dos que apresentaremos no capítulo segundo deste trabalho, diversos casos como esses foram observados por CERASOLI, 2004.

${ }^{83}$ Fundo de Obras Privadas do AHMSP, vol. 118, p. 139-140.

${ }^{84}$ Fundo de Obras Privadas do AHMSP, vol. 413 (encadernados), p. 126-133.
} 
vistas como uma afronta aos anseios estéticos anunciados pela lei de recuos, como explicitado em parecer da Comissão de Obras da Câmara que, durante debate pela retomada da regulamentação, afirma a importância de não tardar a aprovar a medida para evitar a continuação de suas construções na Itatiaia ${ }^{85}$ (FIG. 23-26).

A janela de pressão conquistada pelos construtores de "casas operárias" durante a crise econômica parece se encerrar no ano de 1907, quando o setor da construção civil e o mercado de terras voltam à tona ${ }^{86}$. Em janeiro, o vereador Francisco Antônio da Cunha Horta Junior propõe a retomada do disposto na lei 355/1898 para a Avenida. Em março, a Comissão de Justiça, em parecer assinado por João Mauricio de Sampaio Vianna (ele mesmo proprietário de terras na via) e por Ernesto Goulart Penteado, aprova a medida. Como até então era denominada Itatiaia entre a Avenida Municipal e a Avenida Higienópolis e Angélica no resto, a comissão propõe que a via inteira passe a ser reconhecida pelo nome da filha do barão de Sousa Queiroz, em clara referência ao projeto de elitização que novamente se insinuava.

Ademais, mencionam que os recuos já haviam sido adotados na maioria das construções da via, argumentando que a lei, portanto, não prejudicaria seus proprietários. Apesar da aparente miopia dos vereadores, incapazes de reconhecer as abundantes construções fora dos padrões na área ${ }^{87}$, a exclusão da parte superior da Avenida tratava-se de uma silenciosa fronteira intencionalmente delimitada e mobilizada nas ações e falas de alguns camaristas. Cindindo a via, evitavam suas contradições, bem como desconectavam o anseio de torná-la "uma das melhores ruas da cidade"88, para o passeio e a circulação, dos necessários investimentos em infraestrutura nos trechos superiores. Assim, enquanto as quadras inferiores foram calçadas de paralelepípedos a partir de 1907, o trecho superior, após longos empenhos de seus moradores e proprietários, receberá o mesmo tratamento somente em $1916^{89}$.

\footnotetext{
${ }^{85}$ Câmara Municipal, Correio Paulistano, 25 jan. 1908.

${ }^{86}$ BRITO, 2000 e SIMONI, 2002.

${ }^{87}$ Até o momento somavam-se quase oitenta pedidos de residências "operárias", de acordo com nosso levantamento no Fundo de Obras Privadas do AHMSP.

${ }^{88}$ Anais da Câmara Municipal de São Paulo, 1907, p. 64.

${ }^{89} \mathrm{Tal}$ disparate será analisado com maior profundidade no capitulo dois deste trabalho.
} 
O parecer favorável da Comissão de Justiça é amparado pela Comissão de Obras $^{90}$, sendo o projeto votado e aprovado na mesma sessão, convertendo-se na Lei 1001/1907. A rápida reação de alguns proprietários da Avenida parece explicitar que o plano de Cardim e Burchard, que não obteve adesão entre 1898 e 1902, período de vigência da Lei 355, agora contava com interessados. Até o momento, haviam sido requisitadas cerca de oitenta construções “operárias”, dez de médio padrão e apenas duas residências abastadas. No ano de aprovação da Lei 1001, o caráter dos pedidos de obra muda radicalmente: ainda em 1907 foram requisitados três pedidos para palacetes e quatro licenças para casas médias. No ano seguinte, requisitou-se permissão para outro palacete, além de licenças para catorze casas médias. Em 1909, outro palacete e mais quinze obras médias, a maioria para aluguel, padrão que permaneceu até 1914, quando as requisições de edificações opulentas começaram a superar as medianas. No ínterim, os pedidos para casas "operárias" prosseguiram, porém com expressão cada vez menor.

${ }^{90}$ Comissão composta à altura por Augusto da Silva Telles, Urbano Azevedo e Ernesto Goulart Penteado. 


\begin{tabular}{|l|r|r|r|r|r|}
\hline Ano & BP & BMP & MP & MAP & A \\
\hline 1907 & 2 & 0 & 4 & 2 & 1 \\
\hline 1908 & 5 & 0 & 14 & 0 & 1 \\
\hline 1909 & 12 & 0 & 15 & 1 & 0 \\
\hline 1910 & 6 & 3 & 12 & 4 & 0 \\
\hline 1911 & 5 & 2 & 6 & 0 & 4 \\
\hline 1912 & 5 & 2 & 4 & 3 & 0 \\
\hline 1913 & 6 & 1 & 9 & 2 & 3 \\
\hline 1914 & 3 & 1 & 12 & 0 & 1 \\
\hline 1915 & 4 & 2 & 4 & 0 & 20 \\
\hline 1916 & 1 & 0 & 2 & 2 & 2 \\
\hline 1918 & 1 & 2 & 6 & 1 & 0 \\
\hline 1919 & 3 & 1 & 7 & 2 & 3 \\
\hline 1920 & 1 & 0 & 9 & 10 & 9 \\
\hline 1921 & 1 & 0 & 4 & 9 & 13 \\
\hline 1922 & 2 & 1 & 9 & 7 & 4 \\
\hline 1923 & 1 & 0 & 5 & 8 & 7 \\
\hline TOTAL & 58 & 15 & 122 & 51 & 68 \\
\hline
\end{tabular}

TABELA 2 - Pedidos de obra realizados entre 1896 e 1906 para a Rua Itatiaia e Avenida Angélica. As siglas correspondem a: (BP) baixo padrão; (BMP) baixomédio padrão; (MP) médio padrão; (MAP) médio-alto padrão; (A) alto padrão. $\mathrm{A}$ diferenciação foi estabelecida a partir de critérios: (1) número de cômodos; (2) tamanho do terreno e posição da edificação; (3) sofisticação compositiva e decorativa; (4) tamanho do volume construído. Fonte: Fundo de Obras Privadas do AHMSP. 


\section{Crer para ver: o poder da representação}

Paralelamente aos conflitos de interesses econômicos, corriam também disputas em torno da representação da Avenida Angélica. As lutas simbólicas podem ser flagradas em dois momentos da derradeira discussão em torno da lei de recuos, que tem início em 1908, a partir de uma tentativa de intervenção do prefeito Antônio da Silva Prado por uma nova derrubada da norma. O envolvimento dessa célebre figura dos anais econômicos e políticos da Velha Republica traz outra camada de aspereza desconsiderada por Grostein, Homem e Rolnik ${ }^{91}$ em suas análises aplanadoras de Higienópolis: apesar das alianças e conchavos, as elites também disputavam postos e vantagens entre si. Em perspectiva semelhante à explorada por Paulo Garcez em sua análise da Avenida Paulista ${ }^{92}$, procurarei adentrar brevemente nos meandros de uma luta pela preponderância simbólica do bairro de Higienópolis, porém aqui vivenciada não por imigrantes e nacionais, mas por duas famílias da elite dita "quatrocentona".

Penetrar nessas teias de intriga, apesar da minúcia do objeto, passa ao largo de qualquer purismo ou afinco frívolo a pequenas trivialidades. A partir de suas maquinações, como bem mostra Garcez no âmbito da preservação, foram tomadas muitas decisões da municipalidade, com grande impacto no desenvolvimento da cidade. Para melhor penetrar nesse processo, portanto, é imperioso embrenhar-se no universo do dissenso e do contrário. Permanecemos alheios às motivações e tramoias que moveram episódios que não se enquadram no esquema que supõe a ação predominante de uma elite coesa e forte sobre uma população impotente, marginal e desorganizada.

Outro campo de batalhas detonado pela intervenção de Prado, apesar de já presente na documentação anterior, chega nesse momento ao apogeu de sua evidência. Trata-se do momento em que, seguindo as proposições de Roger Chartier e Bronislaw

\footnotetext{
${ }^{91}$ GROSTEIN, 1987; ROLNIK, 1997 e HOMEM, 1980.
}

${ }^{92}$ MARINS, 2016. 
Backzo $^{93}$, evidencia-se o protagonismo das representações no "fazer-se" da cidade. Em uma contenda entre dois vereadores, veremos duas visões para a Avenida Angélica, duas representações que continham em si práticas e guias díspares para as ações da municipalidade. No episódio, acompanharemos de perto como a experiência da cidade estava estreitamente entrelaçada com suas representações, de maneira que até mesmo as mais evidentes provas materiais poderiam ser ignoradas por seus habitantes e legisladores. Além disso, presenciaremos a potência das representações na tomada de decisões dentro da Câmara Municipal, mostrando como a imaginação social, para além de sua potência simbólica, exerceu papel extremamente ativo nas decisões políticas da cidade - mostrando que, na época, e talvez ainda mais hoje, as estratégias e ações que compunham seu "fazer-se" pautavam-se não apenas por relações materiais. Isso evidencia que as trincheiras da cidade são variadas e que a redação das leis, diferentemente do que propõe Rolnik, davam-se por meios tortuosos e abstratos, distante da racionalidade calculista exclusiva dos interesses econômicos privados.

Vamos então ao caso. Apesar da adesão de alguns membros das elites ao projeto de embelezamento de 1907, outros incomodaram-se com a medida. No ano seguinte, o prefeito Antonio da Silva $\operatorname{Prado}^{94}$ remeteu à Câmara ofício no qual afirmava ser inexequível o disposto na nova lei de recuos, argumentando que na Avenida Angélica havia muitos prédios alinhados à via ou com apenas quatro metros de recuo, sendo a

\footnotetext{
${ }^{93}$ Para ambos os autores, as representações produzidas socialmente estão intimamente ligadas com as práticas sociais. Sendo assim, eles propõem que as representações ocupam um lugar central nas tomadas de decisão dos humanos, e que seriam parte fundamental da formação do habitus de classes e grupos sociais. Para as reflexões de Roger Chartier, Cf. CHARTIER, Roger. História Cultural: entre práticas e representações. Lisboa: DIFEL, 1988 e BARROS, José D’Assunção. A história cultural e a contribuição de Roger Chartier. Diálogos - Revista do Departamento de História e do Programa de Pós-Graduação em História, vol. 9, núm. 1, 2005, p. 125-141. Para as propostas de Backzo, Cf. BACZKO, Bronislaw. Imaginação social. In: Enciclopédia Einaudi. Lisboa: Antropos, 1985. Embora não tenhamos nos aprofundado suficientemente para considerá-lo uma referência teórica deste trabalho, vale salientar os estudos de Serge Moscovici, que procuram aprofundar nos meandros psicossociais de apreensão, formulação e inculcação das representações sociais. Cf. MOSCOVICI, Serge. Representações Sociais: Investigações em Psicologia Social. Petrópolis: Vozes, 2009. Por fim, para a noção de habitus de Pierre Bourdieu, cf. a Introdução deste trabalho.

${ }^{94}$ Filho de Martinho da Silva Prado, um opulento fazendeiro, e Veridiana da Silva Prado, Antonio da Silva Prado foi mais um dos expoentes políticos e econômicos de seu portentoso clã. À altura da década de 1900, além de ser Prefeito da capital, já havia ocupado os altos escalões da política nacional durante o Império, como Conselheiro, chefe do partido conservador da província de $\mathrm{S}$. Paulo até a queda da monarquia, ministro de estado, deputado e senador do Império (LEME, 1905, p. 39).
} 
disposição de seis metros apenas observada, com dificuldade, entre as ruas Palmeiras e Jaguaribe $e^{95}$.

É no mínimo surpreendente a inquietação do prefeito com essa via específica, ainda mais considerando que boa parte de seu mandato foi dedicado aos “embelezamentos" urbanos, confluentes aos anseios subjacentes à Lei de recuos ${ }^{96}$. Contudo, seu envolvimento no caso transcendia sua posição oficial, partindo antes de seus próprios interesses privados. Em 1875, com a morte de seu pai, Antônio Prado tornou-se proprietário da Chácara do Carvalho, composta pelas terras situadas entre a Chácara das Palmeiras e os Campos Elíseos. Nessa área ergueu sua residência entre 1891 e 1893, uma suntuosa edificação desenhada pelo construtor florentino Luigi Pucci. Paralelamente, deu início ao loteamento de suas terras, donde se originou, dentre outras vias, a Alameda Eduardo Prado, nomeada em homenagem a seu pai, o Barão de Iguape ${ }^{97}$.

A princípio almejava conformar na região um espaço homogêneo, semelhante aos empreendimentos vizinhos. Contudo, já nos primeiros anos, suas terras foram ocupadas por diversos segmentos sociais. Na Alameda que levava o nome de seu pai, além de sua própria residência, foram construídos outros palacetes, mas também casas geminadas de baixo e médio padrão, bem como oficinas e outros espaços laborais. Apesar de sua produção tardia, em 1930, o levantamento aerofotogramétrico da SARA-Brasil ajuda a compreender os rumos que tomaram essa ocupação. Nas terras adjuntas à sua morada, vê-se que foram construídos três galpões industriais, bem como séries de "casas operárias” nas proximidades da Sorocabana. Não se sabe a data precisa dessas edificações, mas certamente denotam uma mudança no foco imobiliário de Antônio Prado, que, ao que tudo indica, já se insinuava desde fins do século $\mathrm{XIX}^{98}$ (FIG. 27-28).

Em 1898, um projeto de Lei apresentado por Gomes Cardim previa a desapropriação de todos os prédios que estavam entre a Av. Angélica, que à altura ia

\footnotetext{
${ }^{5}$ Ofício 214/ 1908, referido por diversas vezes nos debates que se sucederam na Câmara. Anais da Câmara Municipal de São Paulo, 1908.

${ }^{96}$ Cf. CAMPOS NETO, 2000, p. 101-191.

${ }^{97}$ BORIN, 2014, p. 7-10.

${ }^{98}$ Idem, p. 47 e 62
} 
até a Rua das Palmeiras, e a Alameda Eduardo Prado, prevendo a ligação entre as duas vias para conformação da Avenida Circular ${ }^{99}$. O favorecimento de tal obra às terras de Prado era tamanho que levou João Antônio Julião, que reeditou o pedido em 1900, a requisitar que fosse anexada nas Atas da Câmara uma declaração em resposta às acusações do Diário Popular de que estaria em conluio com o antigo conselheiro ${ }^{100}$. O prolongamento envolvia ao menos três debates que permearam a Câmara entre 1895 e 1900: o baixo orçamento municipal, a pertinência do projeto da Avenida Circular e a distinção dos direitos e deveres dos agentes públicos e privados na realização dos $\operatorname{arruamentos}^{101}$. A soma desses embates levou a longas discussões em torno da obra, que acabou sendo rejeitada nas duas ocasiões.

Contudo, Antônio Prado permaneceu ativo em seu intento. Em 1901, tornou-se prefeito, recebendo de imediato uma indicação do vereador Serafim Leme, então Chefe da Comissão de Obras, solicitando à Câmara autorização para que a Prefeitura mandasse proceder a estudos e orçamentos para concretizar a extensão. Nesse mesmo ano, o vereador Leme propõe a anulação da Lei 355 para Avenida Itatiaia, podendo também ter sido influenciado pelos interesses de Prado, que vislumbrava o variado potencial comercial de suas terras, que, com a expansão, estaria sob efeito da norma. Provavelmente por conta dos mesmos embates dos anos anteriores, o projeto, novamente, não seguiu adiante.

Alguns anos se passaram e, em 1906, no embalo do entusiasmo econômico que voltava a se insinuar ${ }^{102}$, os vereadores Horta Junior, Sampaio Vianna e Urbano Azevedo indicam outra vez à Prefeitura o estudo do prolongamento da Avenida

\footnotetext{
${ }^{99}$ Projeto ${ }^{\circ}$ 34, Atas da Câmara da Cidade de São Paulo, 1898, v. 83, p. 124.

100 “O sr. João Julião pede que seja anexada à Ata da Câmara uma declaração em resposta ao Diário Popular, que acusou-o de que ao apresentar o projeto de desapropriação de imóveis na Rua das Palmeiras para prolongamento da Av. Angélica (deve ter sido nesse ano, ver atas) teve em vista valorizar terrenos do cons. Antônio Prado, a pedido do próprio. Em seguida diz que a CM não pode tratar das desapropriações por falta de recursos, mas ele tinha em vista prevenir que ali nada fosse construído, tendo em vista que os terrenos serão necessários para a realização futura da Avenida Circular". Correio Paulistano, "Câmara Municipal", 6 mai. 1900.

${ }^{101}$ Sobre as dificuldades do orçamento municipal nas primeiras décadas da República e as tentativas dos camaristas de passar responsabilidades de arruamentos para loteadores, Cf. SIMONI, 2002.

${ }^{102}$ CANO, 1990, p. 122; SIMONI, 2002, p. 132 e 146; BRITO, 2000, p. 103-107.
} 
Itatiaia e solicitam a proibição de edificações nas possíveis áreas de desapropriação ${ }^{103}$. Sendo assim, à altura da aprovação da Lei 1001/1907, Antônio Prado tentava novamente conectar as duas Avenidas, tornando a regulamentação indesejável a seus anseios comerciais heterogêneos.

Paralelamente, Prado parece também disputar um posto simbólico. Enquanto tentava emplacar seu prolongamento, através da lei 906/1906, granjeia na Câmara a mudança de nome da Avenida Higienópolis para Avenida Martinho Prado Jr., em homenagem a seu recém-falecido irmão. A escolha da via não foi fortuita: além da prestigiosa posição que ocupava no imaginário da cidade, ali estavam situadas as residências de sua mãe, Veridiana Valéria da Silva Prado, e de praticamente todos os membros do clã, que se distribuíam na própria Avenida ou em suas redondezas, com exceção do ramo do antigo conselheiro, que vivia nas proximidades de sua Chácara ${ }^{104}$.

O poder simbólico dessa manobra toponímica não deve ser subestimado. Juntamente com a Paulista, a Higienópolis era uma das únicas vias onde o projeto exclusivista vingara até o momento, abrigando numerosos símbolos de prestígio e ostentação erguidos pelos Silva Prado, mas também por outras fortunas, como a de Antônio Álvares Penteado, Sampaio Vianna, Carlos Leôncio de Magalhães, entre outros $^{105}$. Igualar a alcunha do espaço com a do clã significava aglutinar todo esse aparato representativo à sua própria imagem, bem como confundir a narrativa do espaço com a de sua família.

Se a Paulista era o lugar de afirmação das elites imigrantes, a Higienópolis era o espaço de excelência das elites locais ${ }^{106}$. A renomeação da via colocava os Silva Prado em posição de preponderância dentro desse grupo, eclipsando a presença dos outros, que para nomearem sua própria morada passavam a ser obrigados a mencionar o clã do Prefeito. Exemplo nítido pode ser observado no cartão postal “Avenida Martinho Prado" da série B de Guilherme Gaensly, no qual o título entrelaça-se com as

\footnotetext{
${ }^{103}$ Indicação no 157, Anais da Câmara Municipal, 1906, p. 193.

${ }^{104}$ Moravam na Avenida: Caio e Antonieta da Silva Prado, Corina Prado e Joaquim Mendonça, Yolanda da Silva Prado e Flavio Uchoa Filho, Cicero Prado e Stella e Martinho da Silva Prado. HOMEM, 1980, p. 105-109.

105 Ibidem.

106 MARINS, 2016.
} 
qualidades materiais apresentadas na foto, podendo até mesmo levar a crer, para um observador desavisado, que a portentosa residência de Maximiliam Hehl pertencesse ao rol de riquezas e gosto distinto do clã homenageado (FIG.12).

O poder dessa ação pode ser medido pela rapidez com que foi desfeita: pouco depois da assunção de Raymundo Duprat, é proposto na Câmara o retorno do nome original para a via, o que é aprovado em $1913^{107}$. A mesma celeridade com que derrubaram a celebração dos Prado pode explicar o ataque do Prefeito à tentativa de enobrecimento da via vizinha, que levava o nome de uma proeminente integrante das famílias Sousa Queiroz e Aguiar de Barros, e era habitada por sua parentela ${ }^{108}$. Essas famílias, apesar de provavelmente manterem alianças políticas e econômicas com os Silva Prado, muito provavelmente também se enfrentavam com esses em outras arenas, no mínimo por disputas simbólicas e de privilégio. Sendo assim, para além de seus interesses imobiliários, a desregulamentação dos recuos na Angélica servia para o Prefeito desmobilizar a gestão de uma via que dava sinais de poder concorrer em beleza e suntuosidade com a de sua família. Ainda mais tratando-se de uma via vizinha à Martinho Prado Junior, mais extensa e com importância conectiva potencialmente superior.

O ofício do Prefeito Antônio Prado, que advogava pela revogação da Lei 1001 foi colocado em discussão pela Comissão de Justiça em outubro de $1908^{109}$. A Comissão de Obras, por sua vez, por meio de Augusto Carlos da Silva Telles, apadrinhado de Cardim na Câmara ${ }^{110}$, e Goulart Penteado, apresenta parecer discordando do Prefeito sobre a quantidade de prédios sem recuo e propõe um substitutivo, no qual o recuo obrigatório passaria a apenas quatro metros.

\footnotetext{
${ }^{107}$ Lei 1734 de 23 de agosto de 1913.

${ }^{108}$ Cf. capítulo três deste trabalho.

${ }^{109}$ Comissão então formada por Arthur Guimarães Alvaro da Rocha e Sampaio Vianna, este último um contundente apoiador da Lei 1001/1907 no ano anterior.

${ }^{110}$ Silva Telles, assim como Cardim, era engenheiro, formado na Escola Politécnica do Rio de Janeiro. Era um grande entusiasta de transformações urbanas com intuito simbólico com a finalidade de atrair capitais para a cidade, pensamento que expressou em seu livro Os Melhoramentos de São Paulo, publicado em 1906. Segundo os próprios registros da Câmara Municipal, pode-se ver que a relação de ambos era estreita, ao ponto de que, quando Cardim decide abandonar seu mandato em 1906, quem assume sua cadeira é Silva Telles. Cf. SIMONI, 2002, p. 158-174; “Augusto Carlos da Silva Telles", Centro de Memória da CMSP, Seção de Documentação - Vereadores. Disponível em: http://www.camara.sp.gov.br/memoria/vereadores/ (último acesso em fevereiro de 2017).
} 
Após a apresentação dos pareceres, José Oswald Nogueira de Andrade ${ }^{111}$ pede a palavra para encorpar o argumento pela revogação, porém sob outro viés. Dá início a sua fala com a prestimosa epígrafe deste texto: “A Avenida Angélica não é reta”, remetendo à tortuosidade de suas linhas, que prejudicavam a perspectiva barroca ambicionada pelos recuos e evidenciava as sinuosidades de sua composição social. Traça o quadro de um território fraturado com "duas categorias de edificações: [...] de mais ou menos luxo, entre as ruas Piauí e Palmeiras, e edificações modestas, no alto e extremo da mesma, para o lado da Avenida Municipal"112. As duas áreas, explica, eram divididas pelos terrenos baldios que circundavam o Cemitério, dos quais se afastavam as edificações de luxo pelo perigo das moléstias e pela aversão ao "espetáculo" que diariamente ocorria nos fundos da necrópole ${ }^{113}$. Alegando a improvável ocupação dessa área por “edificações de luxo", bem como a rara construção de jardins nas "casas modestas", secunda a revogação da Lei 1001 proposta pela Comissão de Justiça.

Apesar das contundentes observações do vereador, a representação da Avenida Angélica como um espaço de mistura e diversidade foi fortemente repelida pela maioria. Logo após a fala de Oswald, Silva Telles passou a exaltar o glorioso futuro da Avenida, "que se hoje não tem grande importância está, entretanto, destinada a ser uma das mais belas vias da nossa cidade”. A convicção do imanente destino da localidade era tamanha que, em contrassenso à vivência de todos os vereadores, que deveriam circular pelas mais suntuosas residências da cidade, afirmou que "se ainda não há casas de primeira ordem na Avenida Angélica é porque também não há casas de primeira ordem na cidade toda". Terminada sua fala, propõe um substitutivo prevendo a redução do recuo obrigatório para quatro metros. Em situação atípica ao decoro da Câmara, ao menos em seus registros oficiais, Silva Telles foi ovacionado pela

\footnotetext{
${ }^{111}$ José Oswald, além de ser pai do poeta Oswald de Andrade, fez fortuna com loteamentos na cidade, tendo sido o mais expressivo a Vila Cerqueira César, na passagem do século XIX para o XX. ANDRADE, Oswald de. Um homem sem profissão: sob as ordens de mamãe. Rio de Janeiro: Ed. Globo, 2002, p. 75-76. ${ }^{112}$ Anais da Câmara Municipal de São Paulo, 1908, p. 302.

${ }^{113} \mathrm{O}$ eufemismo utilizado pelo vereador parece esconder práticas interditas, sobretudo o sexo. De fato, com o espaço restrito das habitações "operárias" e a vigilância familiar nas residências abastadas, como veremos no capítulo quinto, as práticas sexuais entre namorados ou com cortesãs eram comumente realizadas no espaço público. Na década de 1910, por exemplo, moradores da Rua Alagoas reclamam dos namorados que perturbam o silêncio noturno na Praça Buenos Aires (A gazeta, "Praça Buenos Aires", 4 mar. 1921).
} 
maioria, que o aplaudia em meio a exaltadas exclamações - "Muito bem! Muito bem!"114.

$\mathrm{Na}$ argumentação dos vereadores, vê-se que a representação dos espaços de elite transcendia a esfera da produção e circulação de capitais simbólicos. Na contenda, as diferentes representações do espaço material e social da Avenida, bem como as divergentes narrativas sobre sua trajetória prévia e futura, foram utilizadas como instrumentos para disputar o próprio fazer da cidade.

Consoante à conceituação de Roger Chartier há pouco apresentada, para quem as representações estavam intimamente ligadas às ações sociais, as distintas representações da Avenida sugeriam discrepantes conjuntos normativos que, por sua vez, corroboravam díspares espectros de práticas sociais e construtivas. É ciente dessa corrente causal que Telles, secundado pelos excitados vereadores, ignora as evidências apresentadas por Oswald e refugia-se na abstração do porvir. Surpreendentemente, em contradição com sua formação positivista na Escola de Politécnica, imperava em seu discurso, bem como na anuência de seus "ilustrados" consortes, o "crer para ver"115.

$\mathrm{Na}$ tábula rasa do futuro utópico, universo largamente utilizado pelo cientificismo do qual era oriundo, o espaço da Avenida era apresentado como liso, um vazio a ser preenchido. É nesse ambiente que encontrava sustento aos recuos, que só encontrariam razão se alinhavados com sua caricatura exclusivista e triunfante. Ocupar esse vazio com os corpos, práticas, matérias e desejos disparatados de Oswald colocaria o edifício argumentativo abaixo, e, abraçada à representação, naufragaria a prática que Silva Telles sugeria.

Resguardada na abstração, a representação de Telles apresentava uma modernização harmônica, pacífica e linear, que não demandaria dos legisladores esforços de negociação entre os diferentes anseios que concorriam pelo espaço urbano. A crença nesse processo equilibrado e constante não era mero embuste, embora por vezes tenha sido mobilizada para fins escusos, mas incorporava o horizonte de

\footnotetext{
${ }^{114}$ Anais da Câmara Municipal de São Paulo, 1908, p. 302.

${ }^{115}$ Inversão irônica do estatuto supremo que Augusto Comte legava aos indícios materiais e factuais em sua teoria da ciência, cujo lema pode ser resumido na máxima: ver para crer.
} 
expectativa dos que acreditavam na inevitabilidade do progresso ${ }^{116}$. A representação de Oswald, por sua vez, apresentava uma modernização que, na escala corriqueira, mostrava-se muitas vezes conturbada, disputada e, sobretudo, plural. Sob seu ponto de vista, apesar de terem sido planejados como tal, nem a Avenida Angélica, nem Higienópolis estavam fadados a serem espaços de elite. No cerne dessa constatação, residia o seu potencial prático, que advogava pela mediação dos interesses imobiliários e simbólicos que pairavam na Avenida.

Ao assinalar sua massiva presença, o vereador, que entre 1908 e 1910 empenhou-se em garantir calçamento para a parte superior da Angélica, defendia o reconhecimento de proprietários e moradores de baixa renda como sujeitos políticos e portadores de direitos ${ }^{117}$. Diferentemente de Telles, portanto, não imaginava, por pragmatismo e talvez por convicção, que pudessem ser facilmente removidos para dar espaço a uma via exclusiva. Sendo assim, Oswald preocupava-se com a viabilidade do projeto de embelezamento, uma vez que a Lei 1001 incidia apenas sobre construções novas, com efeito nulo para as já existentes, que seguiriam dissonantes aos padrões almejados.

As facetas normativas da representação de Oswald não chegam a ser elaboradas. Contudo, seu ponto de vista abria um novo campo de conjecturas e efeitos, que os vereadores, convencidos pela representação de Telles e/ou movidos por seus interesses, escusos ou não, preferirem não ingressar, abafando-o com suas aclamações e reverências ao engenheiro. Remetidas novamente às comissões de Obras e Justiça para avaliação do substitutivo, o tema voltou à pauta somente em 1911 - ano em que Antônio Prado passou o cargo de prefeito a Raymundo Duprat -, quando se optou por manter o afastamento de seis metros ${ }^{118}$.

À altura, somavam-se à paisagem da Avenida dezenas de palacetes que eram alçados nas proximidades da Higienópolis, encantando o transeunte com suas rebuscadas fachadas e ousadas volumetrias, enquadradas por amplos jardins, que imprimiam ritmo vagaroso e solene à caminhada. Junto à sombra das árvores que ladeavam, somava-se o bosque da Praça Buenos Aires, concebida e realizada entre

\footnotetext{
${ }^{116}$ SEVCENKO, 1983.

${ }^{117}$ Anais da Câmara Municipal de São Paulo, 1908. Idem, 1909. Idem, 1910.

${ }^{118}$ Anais da Câmara Municipal de São Paulo, 1911.
} 
1910 e 1913. Frente a esse cenário, o "progresso" parecia próximo, tangível, tornando a via um emblema que, nas palavras de Vianna, Goulart e Horta Jr., afugentava "os moldes acanhados em que vivíamos e que tiravam da cidade o caráter de uma cidade moderna" ${ }^{119}$. Para coroar a vitória do embelezamento, em 1912, chegavam os trilhos da Light, efetivando a inserção da via no mapa "oficial" da cidade.

${ }^{119}$ Anais da Câmara Municipal de São Paulo, 1911, p. 222. 



\section{Vias de mão dupla (cap. 2)}





\section{Para além dos jardins, à beira dos portões: a fronteira}

Os recém-chegados bondes da Light subiam e desciam a Angélica e seus passageiros deleitavam-se com a vagarosa e elegante paisagem. Mas chegando à altura do Cemitério, algo de estranho acontecia. Subitamente, o bonde virava na Rua Maceió, como se tomasse um susto, ou se esquivasse de uma aparição indesejada. Lá em cima, as casas geminadas, os armazéns e os botequins seguiam sua vida. E se um passageiro curioso se virasse a bisbilhotar, pensaria estar em outra cidade, pois em extremo contraste com o calçamento bem aparatado, os passeios retilíneos e os ordenados arvoredos que vira abaixo, a parte de cima da Avenida seguia crua: terra batida, sem guias e sem passeios (FIG. 29).

Essa colagem de contrários era mais um dos resultados práticos da representação homogênea da Avenida que, para sustentar-se, relegava seu topo às sombras da ação oficial $^{1}$. Na Câmara, o jogo entre a presença e a ausência da fronteira apontada por José Oswald era constante. Ao se exaltar sua conexão com a Paulista, bem como sua ilustre predestinação, a fronteira era desmobilizada. Contudo, ao se receber as demandas dos moradores do topo por obras e infraestrutura, instantaneamente, o

\footnotetext{
${ }^{1}$ SIMONI (2002, p. 157-160) observa que o mesmo ocorreu em outras áreas da cidade, ou seja, regiões praticamente vazias comumente recebiam infraestrutura antes e em maior abundância do que regiões densamente ocupadas.
} 
limiar era soerguido, dividindo o quinhão da Avenida, sujeito a dois pesos e duas medidas.

Apesar da ocupação da Itatiaia ter iniciado em seu cume, contando já nos primeiros anos do século XX com dezenas de moradores, a primeira indicação de calçamento para a via, realizada por Serafim Leme, em 1904, foi para o trecho entre a Rua Jaguaribe e a Avenida Higienópolis, região que não possuía nenhuma construção, exceto a lateral da residência de Joaquim Machado de Oliveira, que fazia frente à Avenida Higienópolis ${ }^{2}$. Poucas sessões depois, o orçamento para o melhoramento foi aprovado ${ }^{3}$, e durante os três anos entre a aprovação e a realização, mesmo seguindo sem construções, os vereadores Silva Telles e Celso Garcia insistiram por sua concretização ${ }^{4}$.

Para além dos interesses de Telles na almejada Avenida Circular, a medida e sua subsequente imposição davam-se provavelmente a serviço da valorização de terrenos na área. Grande porção permanecia ainda na posse de Germaine Lucie Burchard, filha de Martinho, que passara a administrar os bens do pai após sua morte precoce em $1903^{5}$. Além do patrimônio familiar, a influência de Germaine fora acrescida com seus afortunados casamentos, primeiro com o aristocrata Armand de Gontaut-Biron, e depois com o também fidalgo Roman Sanguzko, permitindo-lhe acumular uma das maiores fortunas imobiliárias da cidade na década seguinte ${ }^{6}$. A indicação também coincide com o interesse de Antonio Ferreira da Rosa, que no mesmo ano pediu licença para a construção de suas nove residências nesse exato trecho da Avenida, bem como com a requisição de João Augusto de Souza Fleury, que se propunha a construir

\footnotetext{
${ }^{2}$ HOMEM, 1980, p. 80.

${ }^{3}$ Lei 793 de 12 de dezembro de 1904.

${ }^{4}$ Indicação n ${ }^{\circ} 145$, Anais da Câmara Municipal de São Paulo, 1905; Indicações no 11, 32 e 102, Anais da Câmara Municipal, 1907.

${ }^{5}$ Podemos constatar que ela possuía grandes porções de terras, pois grande parte do Boulevard só fora arruada a partir de 1914, e, em 1912, ela possuía ainda o quarteirão inteiro entre a Alagoas e a Piauí, que foi desapropriado para a formação da Praça Buenos Aires.

${ }^{6}$ HOMEM, 1980, p. 69-70 e Conferência de Beatriz Bueno apresentada no XIV Seminário de História da Cidade e do Urbanismo, cujo registro, embora sem a informação citada, pode ser encontrado em BUENO, Beatriz. Arqueologia da Paisagem: SIG Histórico e Mercado Imobiliário. Reconstituição do Centro Histórico de São Paulo (1809-1942). Anais do XIV SHCU, 2016. Disponível em: http://www.iau.usp.br/shcu2016/anais/wp-content/uploads/pdfs/44.pdf (último acesso em fevereiro de 2017).
} 
ali um palacete para morada própria ${ }^{7}$. Como expectável, a efetivação do calçamento também coincidiu com o aumento repentino de interesse pela parte baixa da Avenida. Basta lembrar que foi justamente em 1907 que ocorreu a retomada da lei de recuos, paralela ao aumento significativo de pedidos para construção de residências médias, palacetes e casarões na Avenida, cujos proprietários devem também ter participado nos bastidores de proposição e aprovação da medida.

Dois meses antes da indicação de Serafim Leme em 1904, Ignacio Pereira da Rocha, reafirmando pedido já protocolado por João Amarante no ano anterior, requisitou ao Prefeito estudo para reparos na parte superior da Avenida, assinalando que as águas que ali ficavam estagnadas, além de dificultarem o trânsito com a formação de atoleiros, prejudicavam a saúde pública ao favorecer aparecimento de febres nos moradores da região ${ }^{8}$. Mesmo recorrendo ao apelativo argumento sanitarista, diferentemente do pedido de Leme, o de Rocha permanece sem resposta da Prefeitura e tampouco das comissões da Câmara. Em janeiro do ano seguinte, Candido Nazianzeno Nogueira da Motta requisita novamente o calçamento da Avenida Itatiaia entre a Rua Maceió e a Avenida Paulista, que foi retornado apenas em dezembro de 1906, quase dois anos depois, quando a Comissão de Obras emitiu parecer, imediatamente acatado pela maioria, afirmando que o referido calçamento "não é necessário visto que ali moravam poucas pessoas e que se a Câmara for fazer obras em ruas com poucas pessoas não terá dinheiro para fazê-lo em outros locais mais necessitados". Não é difícil imaginar o desdém de Motta ao escutar o posicionamento de seus colegas e ver dar-se poucos meses depois o início das obras nas inabitadas mediações da Avenida Higienópolis.

Mas os camaristas que estavam comprometidos com os proprietários e moradores do topo não se resignaram. Em 1908, o tema voltou à discussão com as indicações de Joaquim Marra e José Oswald, que lograram a aprovação de orçamento para a obra e sua conversão em lei no mesmo ano. Contudo, em 1911 a obra permanecia uma promessa, levando os interessados a remeterem, por meio de Alcântara Machado, um

\footnotetext{
${ }^{7}$ Fundo de Obras Privadas do AHMSP.

${ }^{8}$ Indicação n ${ }^{\circ}$ 169, Anais da Câmara Municipal de São Paulo, 1904.
} 
abaixo-assinado à municipalidade 9 . Com efetivo apoio de alguns camaristas - autores das indicações de calçamento anteriores -, a manifestação, com sessenta e cinco assinaturas, procurava reverter a representação despovoada sustentada pela Comissão de Obras em 1906, apontando para a iniquidade de investimentos ao longo da Avenida Angélica e construindo a imagem daqueles proprietários e moradores como injustiçados, tendo qualquer "travessa nesse bairro, por mais despovoada que seja [...] merecido da Câmara transata as melhores atenções”.

Para além de suas camadas retóricas ${ }^{10}$, principalmente de seu afoito hiperbolismo, o abaixo-assinado permite entrever o impacto da ausência da ação municipal no cotidiano da via, bem como do reforço à divisa que paulatinamente se consolidava em seu trajeto. Durante as chuvas, os descaminhos da água, dada a ausência de canaletas, acabava por muitas vezes invadindo as casas, carregando "quanta imundice" encontrasse pelo caminho. Com os fluidos, adentravam nas residências a umidade e outras impurezas, grandes motivadoras da propagação das enfermidades, dinamizadas ainda pelos fossos abertos no solo bruto da via devido à sua suscetibilidade às incoerentes e abruptas manobras das intempéries.

Os deduzíveis prejuízos das enxurradas não se reduziam ao âmbito físico. Em tempos de pânico sanitarista, o estigma das pestes prejudicava relações institucionais e econômicas de moradores e proprietários. Biaggio Priesco, por exemplo, recorreu a um anúncio pago no Estado de São Paulo, em meados de 1899, para esclarecer ao público e à Câmara Municipal que "não existe moléstia alguma na rua Itatiaia, n. 24A". Explica que a repentina elucidação foi motivada por acabar com as "perseguições [de] todos os dias dos fiscais mandados pelo meu proprietário, que está arrependido do contrato que fizemos"11. Mesmo sem saber qual arrependimento acometia o locatário do italiano, a disputa permite entrever a potência simbólica do tema

\footnotetext{
9 Abaixo-assinado anexo ao processo da Lei 1436/1911, contido no Fundo da Prefeitura Municipal do AHMSP; Indicação 432, Anais da Câmara Municipal, 1911.

${ }^{10}$ Para uma profunda reflexão sobre as estratégias discursivas comumente utilizadas nos abaixo-assinados destinados à Câmara Municipal, cf. CERASOLI, 2004, p. 109-193.

11 “Câmara Municipal”, O Estado de São Paulo, 6 jun. 1899.
} 
sanitário, o qual, em tantas outras situações equivalentes, poderia ser facilmente mobilizado para as mesmas finalidades de calúnia e ameaça aos moradores da via.

O prejuízo dos aguaceiros também era vasto para a circulação de veículos. Sendo a via ponto crucial na conexão entre quatro bairros - Higienópolis, Palmeiras, Santa Cecília e Avenida Paulista - e para a articulação de quatro importantes avenidas Paulista, Palmeiras, Higienópolis e Municipal -, a sua celeridade era constantemente interrompida pelos lamaçais, afirmando os signatários que diariamente era necessário “arrancar à força de braços - automóveis, carroças etc, que pensando atravessarem uma rua perto do centro [...] caem desastradamente nos enormes e perigosos atoleiros, próprios de estradas em pleno sertão".

O ambiente sertanejo também acometia os pedestres, que, na ausência de passeios, eram obrigados a caminhar pela terra, junto aos carros. Nos dias de chuva, ficavam expostos ao lamaçal, nos de secura, envoltos pela poeira, efeito que certamente se estendia às edificações. Não é difícil imaginar o quanto essa paisagem era hostil ao obstinado apreço dos abastados pela limpeza, sendo o zelo por seus veículos, vestes e corpo possivelmente mais um agravante da fronteira. Contudo, mesmo que evitassem o topo da Avenida, nos dias de chuva a lama escorria para a parte baixa, invadindo por vezes até a Avenida Higienópolis. Como uma instigante metáfora do contradito e desajustado crescimento da cidade, a densa mistura que se esparramava era a lembrança de que apesar da aparente segregação, as duas regiões estavam intimamente conectadas.

A estreiteza dessa ligação, aliada com a insistente representação de sua separação, colocava as ações e posturas de alguns camaristas em curto-circuito. $\mathrm{O}$ anseio de tornar a Angélica "uma das mais belas vias da cidade" esbarrava na recusa da maioria dos vereadores em dotar de mínima infraestrutura sua parte superior, e muitas vezes essa recusa vinha dos mesmos que vigorosamente intercediam por seu embelezamento. O topo da Angélica configurava a esquina entre os dois bairros mais portentosos da cidade - Avenida Paulista e Higienópolis -, mesmo assim, permanecia abandonada pelos vereadores que, apesar de alegarem o interesse em seu grandioso 
futuro, pareciam em verdade mais empenhados em desfrutar dos resultados imediatos das ações municipais.

Apesar da enfática argumentação do abaixo-assinado, o calçamento ainda tardou a ser executado. Entre 1912 e 1914, outras partes da via bem menos ocupadas do que seu topo receberam a benesse, como a porção entre a Rua Maranhão e a Piauí (1912), desta até a Alagoas (1913) e então até a Rua Sergipe, em 1914, ano em que o calçamento também foi realizado, finalmente, entre a Paulista e a Municipal ${ }^{12}$. Em 1915, Rocha Azevedo transmite à Câmara o clamor dos moradores do trecho faltante entre Maceió e Paulista -, alegando que os materiais para as obras de calçamento encontravam-se atirados na via desde dezembro de $1913^{13}$. Após a intimidação, as obras têm início e são finalizadas rapidamente. Contudo, essa pequena odisseia tem um desfecho mal-aventurado: já no ano seguinte (1916), o calçamento entre a Paulista e a Pará apresenta falhas, dando início a uma nova jornada de extenuantes requerimentos, árduos debates e persistente esforço de seus moradores na disputa por seu direito à cidade ${ }^{14}$.

\section{O assombroso maquinário do progresso}

Se o passeio pelas calçadas da Avenida assinalava as ambíguas relações da Câmara com os diversos segmentos de sua população, tomando carona em seu bonde, poderemos observar outras interações, ainda mais ambivalentes, que se desenrolavam em seu dia a dia. Através de seus irrequietos movimentos e dos animados alvoroços que se desenrolavam ao seu redor, acompanharemos as movediças, plurais e ambivalentes experiências, expectativas e significações que cercaram a introdução desse artefato à cidade. Nesse campo de vivências, discursos e percepções, poderemos

\footnotetext{
${ }^{12}$ Relatórios do Prefeito de 1912 a 1914, Fundo da Prefeitura Municipal do AHMSP.

${ }^{13}$ Indicação n ${ }^{\circ} 43$, Anais da Câmara Municipal de São Paulo, 1915.

${ }^{14}$ Requerimento n 203, Anais da Câmara Municipal de São Paulo, 1916.
} 
acompanhar outros campos de disputa, fricção e conflito, material e simbólico, constitutivos dessa imbricada modernização. Atritos novamente entre os menos apossados e a municipalidade, mas também entre as próprias elites e segmentos médios, que partilhavam visões multifacetadas e ambivalentes sobre as intensas mudanças que vivenciavam. De início, nos afastemos brevemente do chão da Avenida e façamos uma breve incursão nos recônditos movimentos que circundaram a chegada desse maquinário em São Paulo, para depois mergulharmos novamente, com mais apurada perícia, nas vibrantes tramas de seu cotidiano.

Circular, mover, deslocar, transportar, trafegar, marchar foram os imperativos das cidades ocidentais a partir de meados do século XIX. Do anseio de disciplina e aceleração imposto pela produção industrial à ambição sanitarista de fazer penetrar o sol e o vento e distribuir a água e o esgoto, passando ainda pela ambição de controle do Estado policial e o interesse expansionista dos agentes imobiliários, a movimentação no espaço-tempo tornou-se não só o cerne das intervenções e inovações tecnológicas das cidades, mas também um dos maiores pilares simbólicos de sua modernidade ${ }^{15}$.

Com a ambição de integrar o rol das grandes capitais e dinamizar a circulação de mercadorias e mão de obra em seu espaço produtivo, São Paulo obstinou-se em realizar obras e reformas em seu trânsito. A partir da chegada da linha férrea em 1867, a cidade passa por transformações materiais, ideárias e discursivas que trazem a circulação ao cerne das preocupações de seus poderes instituídos. Cinco anos depois, chegam os primeiros bondes a tração animal, acelerando radicalmente o ritmo da cidade. Em 1875, o Código de Posturas estabelece disposições disciplinadoras ao novo viário, ampliando suas medidas mínimas e obrigando seu traçado reticular. Paralelamente, a administração de João Teodoro dava início às primeiras transformações no Centro, alargando e conectando vias para facilitar o movimento de veículos, inaugurando uma série de obras que se estenderam até meados do século

\footnotetext{
${ }^{15}$ Cf. CAMPOS, 2000 e LIMA, Solange Ferraz de. São Paulo na virada do século. As imagens da razão urbana: a cidade nos álbuns fotográficos de 1887 a 1919. Dissertação (Mestrado) - FFLCH-USP, 1995.
} 
seguinte $^{16}$. Anos depois, com o massivo crescimento da década de 1890, passam a figurar os primeiros planos de maior ambição, como a construção de uma Ferrovia Circular e pouco depois, como já vimos, de uma Avenida Circular. A partir de então, obras viárias de grande proporção serão elaboradas em crescendo até atingirem seu primeiro ápice com o Plano de Avenidas de Prestes Maia. As intenções escusas que eram mascaradas por muitas dessas ações, como a expulsão de populações pobres ou a conformação de espaços exclusivos às elites, revelam a magnitude do poder imaginativo e retórico da circulação à época.

Boa medida desse poder pode ser entrevista na pesquisa de Solange Ferraz de Lima a partir dos álbuns fotográficos da cidade entre 1887 a 1920, alguns produzidos pela própria Prefeitura Municipal, outros por editoras privadas ligadas, em grande parte, às elites políticas da cidade $^{17}$. Nesse universo imagético, onde a cidade era criada e recriada diversas vezes diante de seus leitores, a circulação urbana aparecia com assídua frequência, superando em muito a recorrência de outras temáticas levantadas pela autora, principalmente nos chamados álbuns comparativos ${ }^{18}$. Nesses últimos, não é por acaso que o transporte tenha ganhado tamanha relevância. No universo de cotejo do passado com o presente, a sensação perseguida era de espanto e admiração do leitor perante as radicais mudanças na fisionomia da cidade, que em camadas mais profundas de significação conotavam seu avanço não apenas estético, mas também cultural, econômico, político e social ${ }^{19}$. Para tal finalidade, o trânsito urbano proporcionava momentos notáveis, pois sua modernização implicava em grandes transformações morfológicas, abarcando desde a abertura de fotogênicas perspectivas, até a imponente materialidade dos bondes, com seus trilhos e postes, sem contar o dinamismo das inauditas aglomerações de pedestres que circulavam pelas ruas centrais.

\footnotetext{
${ }^{16}$ Para uma pesquisa detalhada desses melhoramentos, Cf. CAMPOS, 2000.

${ }^{17}$ Em 1907, por exemplo, a Câmara Municipal aprova pagamento para apoiar a publicação Il brasile i gli italiani de Vitaliano Rotellini, destinada a divulgar o país e a cidade na Itália. Parecer $n^{\circ} 37$, Anais da Câmara Municipal de São Paulo, 1907. Cf. também LIMA, 1995.

${ }^{18}$ LIMA, 1995, p. 46-48.

${ }^{19}$ O Estado, por exemplo, era mostrado como sólido e competente. Sua economia, próspera. Suas elites, "civilizadas" por conta do domínio do gosto. O povo, ordenado e dócil.
} 
Seu efeito podemos observar através da pesquisa de Ana Claudia Fonseca Brefe com relatos memorialistas da época. A autora nos conta que "a apologia do progresso completa-se quando os memorialistas se põem a descrever os novos equipamentos modernos - entre eles, o bonde". Ela sintetiza adiante que: "somada a todos os outros aspectos que a cidade adquire, na virada do século XX - nova topografia, novos espaços e uma nova fisionomia -, a técnica - enquanto materialização do progresso -” fazia parte da "trama discursiva" que os permitia "definir São Paulo como lugar da modernidade" 20 .

Em coro com as dezenas de artigos, livros e textos jornalísticos publicados em torno da afirmação do progresso brasileiro, esses álbuns buscavam produzir uma leitura plena, pacífica, positiva e harmônica da modernidade. Fundados no mesmo arcabouço teórico que levara Silva Telles a acreditar no sucesso inexorável da Avenida Angélica enquanto uma imensa passarela das elites, os álbuns advogavam pela utopia cientificista. Assim, por meio da exibição do empenho técnico empregado nas obras viárias e no avanço tecnológico expresso nos meios de transporte, anunciava-se o florescimento da razão redentora em solo paulistano. Nas fotografias, a cidade, e por meio dela, a nação, realizavam seu espetáculo particular, com referência ao mote das Exposições Universais, que era elogiar a técnica e a disseminação do capitalismo industrial, escamoteando suas contradições e violências ${ }^{21}$.

A propaganda, como já vimos, tinha alvos nacionais e internacionais. Ao hemisfério norte, pretendia exibir a solidez econômica, institucional e administrativa da cidade e do país, seguindo à risca os padrões estabelecidos pelas nações desenvolvidas em suas ações e teorizações. No âmbito nacional, como também já vimos, as imagens portentosas de São Paulo visavam colaborar para o projeto

\footnotetext{
${ }^{20}$ BREFE, Ana Cláudia Fonseca. A cidade inventada: a Paulicéia construída nos relatos memorialistas (1870-1920). Dissertação (Mestrado em História)- IFCH, Universidade Estadual de Campinas, Campinas, 1993, p. 128 e 141 apud FREHSE, Fraya. Cartões postais paulistanos na virada do século XX: problematizando a São Paulo "moderna". Horizontes Antropológicos, Porto Alegre, ano 6, n. 13, p. 127153, jun. 2000, p.131.

${ }^{21}$ Cf. PESAVENTO, Sandra Jatahy. Exposições Universais - Espetáculos da Modernidade do século XIX. São Paulo: Hucitec, 1997; BARBUY, Heloísa. A cidade-exposição: Comércio e Cosmopolitismo em São Paulo, 1860-1914. São Paulo: Edusp, 2006 e HADLER, Maria. Trilhos de modernidade: memórias e educação urbana dos sentidos. Tese (Doutorado) - FE-UNICAMP, 2007, p. 37.
} 
hegemônico de suas elites políticas e econômicas. Ademais, os primeiros anos da República mostravam a potência das turbas populares - basta recordar de Canudos, da Revolução Federalista, da Revolta da Vacina, da Guerra do Contestado e, adentrando a década de 1910, das grandes greves operárias. Era imperativo apaziguar os ânimos da população trabalhadora urbana, que, para além das contradições do assalariamento, amargava os tormentos do desemprego e do aumento do custo de vida propiciados pelas subsequentes crises econômicas e pela criação de taxas de consumo, estabelecidas pelo governo federal para aplacar o flagelo das lavouras cafeeiras ${ }^{22}$. Para tanto, era de grande serventia o esplêndido horizonte e a inabalável confiança transmitidos pela utopia positivista, o que também servia à recuperação da confiança dos agentes econômicos locais, que tinham o espírito abalado pelo sinuoso equilíbrio socioeconômico da Primeira República ${ }^{23}$.

Nesse turbulento cenário, quando o bonde elétrico chegou a São Paulo, em 1900 mesmo que com atraso de oito anos em relação ao Rio de Janeiro, e três a Salvador -, seu maquinário foi recebido em acordes triunfantes. $\mathrm{O}$ ano coincidia com a comemoração do IV Centenário do Descobrimento do Brasil, nada mais oportuno para tocar os hesitantes corações e mentes de sua irrequieta população. Se para os representantes de Portugal que participaram dos festejos cariocas a efeméride celebrava o passado heroico e desbravador de sua nação, a celebração no Brasil pretendia exaltar seu futuro, apoiando-se, para tanto, em uma narrativa histórica que comprovasse seu irrefreável caminho em direção ao progresso. Dentre os meios letrados, davam conta desse discurso as publicações que saíam através do IHGB e da Associação do IV Centenário, com a finalidade de mitigar as ideias que advogavam contra o progresso brasileiro, a exemplo de Porque me ufano de meu país, de Afonso Celso de Assis Figueiredo, e dos Contos Pátrios, de Olavo Bilac e Coelho Neto ${ }^{24}$.

\footnotetext{
22 SEVCENKO, 2010, p. 55-75.

${ }^{23}$ Para explicação mais detalhada sobre o que entendo aqui como utopia positivista, cf. Introdução deste trabalho e SEVCENKO, Nicolau. O cosmopolitismo pacifista da Belle Époque: uma utopia liberal. In: Revista de História, n. 114, USP, São Paulo: janeiro-junho, 1983.

24 OLIVEIRA, Lúcia Maria Lippi. Imaginário Histórico e Poder Cultural: as comemorações do Descobrimento. Revista Estudos Históricos, v. 14, n. 26, 2000 e CERRI, Luis Fernando. Festas nacionais:
} 
Para a conquista da grande população, organizavam-se nas capitais a distribuição de loterias e itens comemorativos e a inauguração de monumentos, sem falar da organização de festejos privados e públicos que ensejavam rebentar-lhes o espírito cívico e patriótico. Enquanto os discursos escritos e os festejos garantiam coerência ao passado, ao presente cabia apresentar as provas de sua proeminência, papel que, no caso paulistano, foi desempenhado pelas inovações materiais e tecnológicas do bonde elétrico.

Ligando a Barra Funda, morada do recém-apossado prefeito Antônio da Silva $\operatorname{Prado}^{25}$, com o Largo de São Bento, a primeira viagem foi marcada por uma série de ritos protagonizados por empresários da Light and Power Company e pelos mais proeminentes políticos do Partido Republicano Paulista (PRP), com exceção de Campos Salles, que presidia as comemorações da capital federal. Por volta do meiodia, após um batalhão de discursos no escritório da empresa, à Rua Direita, os notórios seguiram para seu estacionamento na Rua Libero Badaró, que encontraram enfeitado com bandeiras de diversas nações, com destaque para os pavilhões brasileiro e norteamericano, que também decoravam as novas e vistosas máquinas ${ }^{26}$.

A carga simbólica que perpassava o cerimonial não poderia ser mais evidente: quatro séculos após a chegada da primeira força "civilizadora" ao país - os portugueses $^{27}$-, a cidade dava uma nova guinada em direção ao progresso, alinhavando seu caminho com a mais pujante nação do continente na substituição da modorra de sua força propulsora - o burro - pelo dinâmico impulso da eletricidade. Ao som dos hinos nacionais dos Estados Unidos e do Brasil, embarcaram nos vagões e deu-se a partida do passeio inaugural. A cobertura do Correio Paulistano, órgão oficial

uso e ditatização do saber histórico nas pedagogias do cidadão. História \& Ensino. Londrina, v. 9, p. 205222, out. 2003.

${ }^{25}$ Para um olhar mais aprofundado sobre as negociações de Prado com a Light, cf. BORIN, 2014, p. 45-58.

${ }^{26}$ Mesmo tendo capitais majoritariamente canadenses, não encontramos explicação para as notícias remeterem exclusivamente aos símbolos dos Estados Unidos.

${ }^{27}$ Lúcia Lippi explica que à época isso era debatido, e havia muitos que valorizavam o passado americano em detrimento das evocações lusas. Contudo, nas comemorações preponderam estas últimas, que, ao ver da historiadora, eram ainda mais difundidas à época. OLIVEIRA, op. cit., p. 186-191. 
do PRP, grande entusiasta do ideário cosmopolita, salientou o fervor entusiástico que tomara conta da população ${ }^{28}$ :

Nas ligeiras linhas de uma notícia que se ressente da pressa com que é traçada, é impossível dar a medida exata da intensidade da alegria e da satisfação que se liam em todos os semblantes pela realização do notável melhoramento. Era indescritível o entusiasmo que se apoderou do povo que se apinhava nas ruas por onde passaram os veículos e, quando estes, após a viagem inaugural, foram franqueados ao público, mal se pode imaginar o movimento de invasão que se observou: todos à porfia se esforçavam por obter lugares nos veículos, sendo, porém, de notar que, apesar do atropelo, não se registrou o menor incidente que viesse dar nota desagradável à grande festa que a população se associou nas mais francas expansões de jubilo ${ }^{29}$.

O enquadramento da reportagem do Correio, igualmente adotado pelo Estado ${ }^{30}$, transformara o lançamento do bonde em uma comunhão catártica entre as elites e o povo, que abria portas e deitava-se nas janelas para celebrar e aplaudir o bonde, deleitando-se em assistir seus dirigentes montados no prenúncio do progresso, o triunfo da civilização (FIG.30). Essa moldura em muito se assemelha aos álbuns comemorativos: o elemento técnico é celebrado e apreciado de maneira harmônica, pacífica e extática. Contudo, apesar de potente, a voz dos editores não era unânime. Logo na primeira página da edição seguinte do Correio, o engenheiro Samuel Augusto das Neves, sob o pseudônimo de Zé Basilio, verte sua perspectiva negra sobre o evento:

O povo é o diabo.

Não tem o que ver. Gosta que se derrete de novidades.

O povo de S. Paulo tinha a Viação há muitos anos, e com ela se arranjava.

Já estava afeito às discussões dos cocheiros, aos mimos da taca nas espáduas dos pobres orelhudos.

Esperava horas e horas o bondinho amigo, e assim viveu, suportando a Companhia $[. .$.$] .$

Ora arranjava troco, ora não, sofrendo com paciência as fraquezas dos burrinhos quando a alfafa estava cara, rindo de contente quando não havia escassez de milho.

\footnotetext{
${ }^{28}$ Para uma análise mais detida nos posicionamentos políticos do jornal, Cf. CASTRO, Ana Claudia Veiga de. A São Paulo de Menotti del Picchia. São Paulo: Ed. Alameda, 2008, p. 68-87.

${ }^{29}$ Correio Paulistano, 8 mai. 1900.

${ }^{30}$ Estado de São Paulo, “The São Paulo Raliway Light e Power Company, Ltda”, 8 mai. 1900.
} 
Às vezes reclamava do poder competente qualquer providência, mas assim como um namorado reclama à futura sogra contra um muchocho ${ }^{31}$ da menina dos seus olhos.

De vez em quando (coisa natural entre amigos) lá vinha pelos jornais uma mofinasinha ${ }^{32}$ meio azeda. Mas ela, solícita, muito cheia de considerações, contando com o apoio da maioria, respondia que não, que a razão estava do lado dela.

E assim ia S. Paulo muito bem e da mesma maneira o seu pacato Zé com a Viação na ponta.

Certo dia, triste dia, apareceram na Rua XV umas caras estranhas - uns barbados, outros de cara de padre; pisando duro - tuc, tuc - com umas botas muito forte, muito bem feitas; chapéus brancos de feltro; umas calças finas, como lã de cágado.

Aqui, que nos conhecemos todos, começaram a perguntar ao comendador Sousa:

- Quem são estes padres? Que querem esses homens? Isto aqui não é Cuba... ${ }^{33}$

— Esta gente é a Light and Power, são do Canadá [...]

— Estes hão de tocar a Viação p'ra fora. [...]

Um belo dia, diabello, elegeram umas vigas de aço duplo T. Que enormes T T.

- Oh ferro - gritou Zé povo - nunca vi tanto aço. [...]

- Isso é conversa fiada: trilhos velhos de uma Companhia que estourou em Toronto. [...]

A esse tempo já os tribunais tratavam da lide e a maldita Noite, de saudosa memória, lançava terríveis artigos subordinados à epigrafe - a eletricidade $e$ os burros.

Segue, não segue os trabalhos, o tribunal decidiu que seguisse o bonde elétrico.

Os americanos exclamaram:

- Oh! Sose, Tribunal estar muito boa. Vai tome garrafa cerveja, e faz brinde de ministros tudas. Vai escreve States, diz que mande posts e bonds eletrics e vai faz uma represa im Paraíba. Oh yess. Vive imprensa de S. Paulo!

E os malvados esburacaram o chão das ruas, encheram-nas de postes, de tubos, de cabos, dos diabos. [...]

\footnotetext{
${ }^{31}$ Um beijo.

${ }^{32}$ Uma desdita.

${ }^{33}$ Provável referencia à Guerra Hispano-Americana, resultante da intervenção dos Estados Unidos na Guerra de Independência de Cuba em 1898, que ao final resulta no Tratado de Paris, que cedeu controle temporário da ilha aos norte-americanos.
} 
E virou e mexeu e apareceu o bonde elétrico, cheio de gente, embandeirado, limpo, elegante e andando, subindo e descendo ladeiras, sem burro nem nada;

- Um desaforo!

Mas a coisa não ficou aí:

Zé Povo, entusiasmado, batia palmas, estava em multidão em todo trajeto do bonde. O moçame bonito - pactuando com ele e a criançada de S. Paulo que é dos diabos - progressista, bonita, futurosa, num alegrão desesperado: Papae, o bonde elete!

- Cala boca menino, deixa o bonde passar ${ }^{34}$.

Nas palavras do engenheiro, topamos com a ponta diametralmente oposta ao ufanismo positivista que louvava o capitalismo internacional: o pessimismo passadista e localista. Sendo ele mesmo um ativo acionista de empresas locais dedicadas à urbanização e um grande executor de obras de infraestrutura na capital e no Estado, não é de se estranhar seu posicionamento frente à violenta cisma entre a Companhia Viária Paulista, de capital inteiramente nacional, e a estrangeira Light ${ }^{35}$. As contradições da solidariedade e interdependência entre as nações promovidas pelo cosmopolitismo não escapavam ao empresariado local. Enquanto favorecia o desenvolvimento da economia agroexportadora, como era o caso da possante cafeeira, o internacionalismo colocava sob grandes apuros os nacionais que se aventuravam na produção de manufaturas e realização de serviços de grande vulto. Afinal, no tacanho contrato liberal, essas atividades eram primado das nações do Norte, sobrando a eles apenas o consumo, os serviços corriqueiros e o fornecimento de matéria-prima. Daí a impugnada zombaria, repleta de ira e indignação, contra o "entreguismo" dos jornais e do Estado no caso da Light, sob a égide de um amargo letreiro, que não poderia ser mais explícito quanto ao teor de sua coluna: "O povo ingrato" 36 .

Fora isso, no caso de um indivíduo nascido em 1863 - crescido, portanto, em um ambiente fronteiriço à modernidade -, as volumosas transformações da década de 1890 desaguavam no que Marshall Berman bem definiu como a "sensação de viver em

\footnotetext{
${ }^{34}$ Correio Paulistano, “A ingratidão do povo e a Light”, 9 mai 1900.

${ }^{35}$ NASCIMENTO, Ana Paula. Samuel das Neves: engenharia, urbanismo e periodismo. VII Seminário Nacional do Centro de Memória, Campinas. Anais: Campinas, Unicamp, 2016.

${ }^{36}$ Embora o termo entreguista não fosse corrente à época, popularizando-se apenas na década de 1950, a postura crítica apresentada por Neves é semelhante à cultivada em meados do século XX.
} 
dois mundos simultaneamente" ${ }^{37}$. Diante do mistério da modernidade, essa posição, compartilhada por muitos de seus contemporâneos, muitas vezes descambava para o ceticismo e a desilusão em detrimento da esperança e da utopia. Desse duplo lugar, de indivíduo e agente econômico, Samuel constrói um retrato da cidade em que o elemento exógeno não aparece como redentor, mas como corruptor de uma ordem estabelecida. Uma ordem imperfeita, mas suavizada pela amistosidade comunitária, em que os conflitos eram dissolvidos na doce atmosfera de amor e ódio, própria às relações familiares e amorosas. O autor apresenta a cidade como uma aldeia, cujo isolamento seria a garantia de proteção e bem-estar, e enraíza no presente as esperanças de uma boa vida, povoando, inversamente à retórica positivista do "atraso", a tecnologia, o novo e o futuro com temerosas assombrações.

Ao passo que a técnica, a modernização e o cosmopolitismo deslumbravam, eles também inauguravam novas ameaças. Contudo, entre a luz e a escuridão das leituras distantes e interessadas do Correio e de Samuel das Neves, as entranhas da turba que recebia a invenção eram policrômicas e periclitantes:

Anunciou-se que São Paulo ia ter bondes elétricos. Os tímidos veículos puxados a burros, que cortavam a morna cidade provinciana, iam desaparecer para sempre. Não mais veríamos, na descida da ladeira de Santo Antônio, frente à nossa casa o bonde descer sozinho equilibrado pelo breque do condutor. E o par de burros seguindo depois.

Uma febre de curiosidade tomou as famílias, as casas, os grupos. Como seriam os novos bondes que andavam magicamente, sem impulso exterior? Eu tinha notícia pelo pretinho Lázaro, filho da cozinheira de minha tia, vinda do Rio, que era muito perigoso esse negócio de eletricidade. Quem pusesse os pés nos trilhos ficava ali grudado e seria esmagado facilmente pelo bonde. Precisava pular. [...]

O projeto aprovado, começaram logo os trabalhos da execução. E anunciaram que numa manhã apareceria o primeiro bonde elétrico. Indicaram-me a atual Avenida de São João como o local por onde transitaria o veículo espantoso.

Um mistério esse negócio de eletricidade. Ninguém sabia como era. Caso é que funcionava. Para isso, as ruas da pequena São Paulo de 1900 enchiam-se de fios e de postes. [...]

${ }^{37}$ BERMAN, Marshall. Tudo que é sólido desmancha no ar: a aventura da modernidade. São Paulo: Companhia das Letras, 1986, p. 16. 
Um amigo de casa informava: - o bonde pode andar até a velocidade de nove pontos. Mas, aí é uma disparada dos diabos. Ninguém aguenta. É capaz de saltar dos trilhos. E matar todo o mundo...

A cidade tomou um aspecto de revolução. Todos se locomoviam, procuravam ver. $\mathrm{E}$ os mais afoitos queriam ir até a temeridade de entrar no bonde, andar de bonde elétrico!

Naquele dia de estreia ninguém pagava passagem, era de graça. A afluência tornou-se, portanto, enorme.

No centro agitado, eu desci a ladeira de São João que não era ainda a Avenida de hoje. Fiquei na esquina da rua Líbero Badaró, olhando para o largo de São Bento, de onde devia sair a maravilha mecânica.

A tarde caía. Todos reclamavam. Por que não vem?

Anunciava-se que a primeira linha construída era a da Barra Funda. É pra casa do prefeito! - O bonde deixava o Largo de São Bento, entrava na Rua Libero Badaró, subia a Rua São João, entrava na Rua do Seminário.

Um murmúrio tomou conta dos ajuntamentos. Lá vinha o bicho! O veículo amarelo e grande ocupou os trilhos do centro da via pública. Um homem de farda azul e boné o conduzia, tendo ao lado um fiscal. Uma alavanca de ferro prendia-o ao fio esticado, no alto. Uma campainha forte tilintava abrindo as alas convergentes do povo. Desceu devagar. Gritavam:

- Cuidado! Vem a nove pontos!

Um italiano dialetal exclamava para o filho que puxava pelo braço:

— Lá vem o bonde! Toma cuidado!

O carro lerdo aproximou-se, fez a curva. Estava apinhado de pessoas, sentadas, de pé. Uma mulher exclamou:

- Ota gente corajosa! Andá nessa geringonça!

Passou. Parou adiante, perto do local onde se abre hoje a Avenida Anhangabaú. Houve tumulto. Acidente?

Não andava mais, gente acorria de todos os lados. Muitos saltavam.

— Rebentaram a trave do lado! Não é nada!

Tiravam a trave quebrada, o veículo encheu-se de novo, continuou mais devagar ainda, precavido.

E ficou pelo ar, ante o povo boquiaberto que rumava para as casas, a atmosfera dos grandes acontecimentos. Nas ruas, os acendedores de lampião passavam com suas varas ao ombro acendendo os acetilenos da iluminação pública. 
$\mathrm{Na}$ lembrança de Oswald de Andrade, inscrita em seu livro de memórias ${ }^{38}$, a vibração alternada de seu próprio ânimo expressa toda a sorte de boatos que cercavam o mistério da eletricidade. A admiração e o receio não conheciam fronteiras individuais, nem sociais. Era um grande momento, uma revolução, mas com consequências imprevisíveis. A experiência das novas materialidades e sociabilidades eram explosivas e contraditórias, nervosas e excitantes. Nem destemidamente entusiasmados como nos exaltados discursos positivistas, tampouco infinitamente traumatizados como na prosa romântica e passadista, os corações e mentes que encaravam a modernidade eram acachapados, revirados e invadidos pelos ambíguos mares do medo, da maravilha, do júbilo e do horror ${ }^{39}$.

E apesar da aparente confiança na harmonia pacífica do progresso, nessa vaga de contradições também estavam imersas as elites. Em última instância, seus bairros exclusivos eram um esforço de destilação da modernidade, mas as raízes que uniam a pobreza à riqueza e a violência ao conforto eram demasiadamente profundas. Construir uma verdadeira Higienópolis, como vimos há pouco, revelara-se tão desafiador quanto dividir um átomo.

Se nas ruas os encontros já se tornavam suficientemente indesejáveis, o espaço dos bondes era um traiçoeiro catalisador desses choques. Sua restrita espacialidade colocava em contato contínuo os hábitos e expectativas de todas as classes sociais. Não à toa, desde os modelos movidos a tração animal, frustrados com a inquietude que tomava seu passeio, os abastados expressavam sua insatisfação no Correio Paulistano, exigindo às autoridades que estabelecessem normas de conduta aos passageiros ${ }^{40}$. Da modernidade queriam a velocidade, mas não a diversidade; sonhavam com o crescimento econômico, mas sem a presença de trabalhadores. Dispositivos de controle foram estabelecidos pelas autoridades, mas mesmo assim as diferenças persistiam. Ao ponto de que, com o lançamento dos elétricos, foram colocados em

\footnotetext{
${ }^{38}$ ANDRADE, Oswald de. Um homem sem profissão: sob as ordens de mamãe. Rio de Janeiro: Ed. Globo, 2002, p. 74-75.

${ }^{39}$ BERMAN, op. cit.

${ }^{40}$ FREHSE, 2000, p.126-129.
} 
circulação veículos de luxo em paralelo aos corriqueiros. O acesso a cada um, naturalmente, era delimitado pelo preço.

Quase trinta anos depois de seu primeiro impulso, uma crônica publicada no Diário Nacional, intitulada "Os bondes também têm alma", nos permite acompanhar de perto as contraditas expectativas que circundavam a modernidade do elétrico. Através da imagem de dois bondes separados, o texto descreve as duas faces contraditas do progresso. Perversamente, dedica toda a ode à civilidade aos modelos de luxo, reservando a Babel da barbaridade aos populares. Para além do preconceito implícito quanto ao modo de vida dos trabalhadores, por meio da descrição de comportamento, personifica as ocorrências como se tivessem raízes exclusivas na profunda individualidade de cada um, cuja imagem da alma não poderia ser mais imprecisa ao se ignorar as distintas condições de vida reservadas aos proprietários e trabalhadores no regime capitalista.

Sob os olhos do cronista, no bonde do Brás, reinavam as almas rudes e malcriadas, onde só "um santo ou energúmeno podem viajar impunemente":

“Não seja animal! Não me pise nos calos!”... “Chegue mais para lá! Quem tem essas banhas compra automóvel ou anda de aranha."... - "Você pensa que eu vou tolerar durante a viagem as bicadas que a sua galinha me está dando, de dentro da cesta?"

"Olhe que eu atiro esse gato que trás no saco ali no Tamanduateí, e você atrás dele para o salvar!”

De repente a "alma” do bonde toda se alvoroça. Que foi? Que não foi? Pouca coisa.

$\mathrm{O}$ condutor que atirou um murro à cara de um pingente, pondo-lhe o nariz como um caqui maduro.

O pingente, por sua vez, retribui a gentileza com um pontapé, que desviado a tempo, vai apanhar em cheio a vasta região abdominal de uma vendedora de verduras.

A mulher põe-se a urrar, com método, enquanto os passageiros gritam que se linche o homem.

Que homem, o pingente? Absolutamente não! O condutor. O condutor, sim senhores, que não devia de forma alguma ter desviado do pontapé.

Porque ali é mesmo assim. O que é seu, a seu dono. E um pontapé que nos pertence não deve acertar em mais ninguém... 
Como evidencia o próprio texto, a desordem e a rudeza não têm origem na "alma" de seus passageiros, mas em uma situação específica, bastante conhecida de seus contemporâneos: a superlotação ${ }^{41}$. Provavelmente acirrada pela pressa e o estresse mental que preenchiam a rotina cronométrica da maioria trabalhadora, não é de se estranhar que a atmosfera de conflito e alvoroço fosse latente. Em oposição à algazarra, os bondes de Higienópolis e da Barra Funda assemelhavam-se a um paraíso civilizatório:

Estes bondes possuem uma alma completamente diversa.

São almas educadas, que conhecem a regra das boas maneiras, que cedem o seu lugar, que não fumam nos primeiros bancos, que escolhem lugar para cuspir.

Há na alma destes bondes, um cheiro vago de Água de Colônia, e um aroma indeciso de máquina de escrever.

De resto, nada de inconveniências, nada de palavrões, e, sobretudo, nada de pontapés atirados aos outros que acertam na gente.

Tem-se a sensação de que a alma destes bondes fez o seu curso ginasial, fez a sua primeira comunhão, e está fazendo agora, nas horas vagas, a sua leitura clássica.

Os condutores, mesmo, como parte integrante dessa alma, trazem sempre a barba feita [...], os sapatos limpos. E usam meias!

Os bondes são asseados, não cheiram senão a verniz e param nos postes regulamentares. Mas há uma circunstância que caracteriza de todo a alma destes bondes: o troco que os condutores dão está sempre certo! E, quando acaso a gente recebe uns tostões a mais e os devolve, o condutor tira o boné e pede mil desculpas por se ter enganado.

Alma encantadora a dos bondes de Higienópolis! $!^{42}$

Um pequeno Éden mantido pelos privilégios que lhe concedia a Light. Por se tratar de modelos de luxo, a empresa dedicava empenho que fizesse valer o preço cobrado. Escolhia os cobradores com índole mais conveniente e obrigava-os a manterem a visada bem asseada, como se fossem mais uma das peças diligentemente higienizadas

\footnotetext{
${ }^{41}$ TERRA, Paulo Cruz. Conflitos cotidianos e motins: os usuários de bondes no Rio de Janeiro no final do século XIX e início do XX. História Social, n. 22 e 23, Campinas, 2012, p. 237 e SANTOS, João Marcelo Pereira dos. Os trabalhadores da Light São Paulo, 1900-1935. Tese (Doutorado) - IFCH-UNICAMP, 2009.

${ }^{42}$ Diário Nacional, "Os bondes também têm alma”, 29 jan. 1928.
} 
do carril $^{43}$. A cordialidade entre os passageiros, afora a educação burguesa da maioria, que resguardava a violência em outros âmbitos, era mantida pela ocupação razoável do espaço, evidenciada até mesmo nas ilustrações que acompanhavam a matéria: os corpos do bonde de luxo aparecem alinhados, enquanto no outro aparecem sobrepostos $^{44}$. Sob essas condições, rareavam motivos para aflição e confronto, sobrando condições para o deleite, o flerte e - como nunca faltava à rotina dos abastados - a exibição. A crônica termina aferindo uma conclusão máxima: "cada bonde de São Paulo tem uma alma original, própria, inconfundível: a alma do bairro a que serve e da gente que transporta" (FIG. 31).

Sendo assim, conhecendo a diversidade que povoava a Angélica, não seria de se estranhar que ali os bondes também apresentassem múltiplas faces. Ausentes na fotografia oficial, essas se faziam presentes nos jornais pelos desastres e reclamações. Em 1910, a Light requisita a diminuição da frequência de bondes comuns na linha Higienópolis. Recebendo o aval da Prefeitura, tenta colocar o plano em ação no ano seguinte. Ao saber das intenções da multinacional, sob o eloquente e trágico codinome “as vítimas”, moradores da região assinam um artigo de revolta no Diário ${ }^{45}$ :

Sr. Redactor - Vai ser suprimido, de 5 do corrente em diante, o bonde 27, Hygienopolis, via Palmeiras, e, é lamentando esta perda, que muitas pessoas prejudicadas apelam para o Diário.

$\mathrm{O} \mathrm{X}$ da Light é encompridar as viagens dos seus carros, para as tornar mais lucrativas, ao passo que o povo busca o caminho mais curto à volta ao descanso, das agruras da luta diária.

Compreende-se o prejuízo, fazendo-nos suportar uma viagem de 30 minutos, quanto fazíamos em 10, saindo do centro através do baixo Acú, por Santa Efigênia até Barra Funda, ou pelo Piques e Consolação, para chegarmos ao bairro do Coração de Maria [Campos Elíseos].

Muito disputado este bonde nas horas de regresso, pela sua escassez, como se arranjarão esses moradores da extensa rua Martim Francisco e suas transversais, alameda Barros, Imaculada Conceição, Canuto do Val, Abrantes, Baronesa de Itú, Jaguaribe, avenida Angélica, Barão de Tatuí,

\footnotetext{
${ }^{43}$ SANTOS, op. cit., 89-90.

${ }^{44}$ Além do controle da superlotação, nos bondes de luxo era proibido carregar ferramentas, caixas, etc. Contrato firmado entre a Light e a Prefeitura em 1909. Fundo da Prefeitura Municipal, Diretoria de Obras, caixa 522.

${ }^{45}$ Diário, 4 nov. 1911. Fundo da Prefeitura Municipal, Diretoria de Obras, caixa 522.
} 
Verona e Vitalis, com sua supressão? Pela reclamação que ora fazem, confiarão no prefeito e nos srs. Vereadores, fazendo dissuadir a Light desta supressão, que só lhe poderá acarretar prejuízos. - as vítimas

A eficácia desse tipo de manifestação, talvez apoiada por outros movimentos indisponíveis aos nossos olhos, mostra-se outra vez, agora com maior contundência do que na disputa pelo calçamento do topo da Angélica. Após a indignação civil, praticamente de imediato a Prefeitura recua em sua decisão, obrigando a Light a manter os horários e carros na supracitada linha.

Nas coléricas palavras das "vítimas", podemos entrever ainda outra contradição da aceleração do tempo-espaço proporcionada pelo bonde. Se no discurso tecnicista este aparecia como uma promessa de libertação e facilidade, permitindo a redução do tempo de deslocamento e ampliando a duração do descanso, no correr do cotidiano seu impacto implicara conjuntamente no seu oposto. Certamente muitos se privilegiaram da rápida superação das distâncias. Em situações emergenciais, o hospital estava mais próximo, bem como o estavam os parques e a radiante vibração do Centro. A experiência do bonde em si também devia ser encantadora, um passeio repleto de deleite para quem se colocasse em disposição contemplativa. E talvez a algazarra também fosse vivida com certa jocosidade e alegria, afinal, não deixava de ser um potente espaço de sociabilidade. Junto às confusões, o passeio no elétrico devia ser permeado por risadas, conversas compenetrantes e distraídas, palco de encontros fortuitos, trocas de ideias e notícias, numa espécie de botequim sobre rodas, com menos bebida e maior diversidade social.

Contudo, na voz dos vitimados de Higienópolis, podemos entrever sua outra face. A ansiedade pelo "caminho mais curto", no qual o atraso de vinte minutos era capaz de gerar grande indignação, era expressão de um cotidiano que, por sua dinamicidade, tornava-se cada vez mais sobrecarregado. Abarrotavam o trabalhador suas responsabilidades - multiplicadas pela ampliação das tarefas burocráticas e pela restrita faixa temporal que passava a reger o horário comercial -, dificultadas, contraditoriamente, pela ampliação das distâncias, que se tornavam cada vez maiores em igual proporção à capacidade de superá-las com velocidade. O “operário da democracia” celebrado por Olavo Bilac em 1903, junto ao trem e o ônibus, catalisara a 
dispersão periférica da cidade ${ }^{46}$, a qual anulava não só as vantagens da velocidade, mas também aquecia as especulações sobre terras e loteamentos, dificultando ainda mais o fornecimento dos serviços básicos de infraestrutura pelo Estado. Grande agravo vinha também dos argutos patrões, que não demoraram a perceber que, com a facilidade do deslocamento, poderiam aproveitar mais horas de sua força trabalhadora. A máquina abria possibilidades, mas aproveitá-las como oportunidades para a libertação ainda dependia dos seres humanos.

Vide o caso das superlotações promovidas pela Light, que na Angélica mostravam sua mórbida face. No cotidiano da via, não eram raras as quedas de pingentes, ocasionadas por um obstáculo no trilho, uma freada brusca ou um sacolejo repentino. Às vezes repercutiam em lesões leves, outras vezes graves, mas tinham seu pior desfecho quando o passageiro derrubado era atingido pelas rodas do próprio bonde ou de outro veículo. Atrapalhando o público, em pleno passeio das elites, estendiam-se os corpos no chão ${ }^{47}$ (FIG. 32-35).

Os desvios da máquina do trilho que lhe havia imposto a humanidade já eram velhos conhecidos da cidade. Desde seus modelos mais antigos ${ }^{48}$, os bondes protagonizavam trágicos choques e atropelamentos, tornados mais traumáticos pela potência do elétrico, e que por vezes transpassavam as fronteiras de idade, cor ou classe social ${ }^{49}$. Contudo, essas fronteiras existiam e demarcavam agentes bastante específicos. Nas primeiras décadas do bonde a tração animal, Fraya Frehse constatou que a maioria dos acidentados ocupava as fileiras dos pobres pouco remediados ${ }^{50}$. O cenário não parece ter mudado com a chegada do coletivo elétrico ${ }^{51}$. Um número que não surpreende se nos lembrarmos que eram justamente os trabalhadores que

\footnotetext{
${ }^{46}$ Refiro-me ao texto: "Em trinta e cinco anos, esse operário da democracia estendeu por todas as zonas da urbs o aranhol dos seus trilhos metálicos, e senhoreou-se de todas as ruas urbanas e suburbanas, povoando bairros afastados, criando bairros novos, alargando de dia em dia o âmbito da capital, estabelecendo comunicações entre todos os alvéolos da nossa imensa colmeia. São dele as ruas, são dele as praças, tudo é dele, atualmente". BILAC, Olavo. "O Bond". Obra reunida. Rio de Janeiro: Nova Aguilar, 1996, p. 435 apud TERRA, 2012, p. 236.

47 Cf. as edições d'O Correio Paulistano referentes aos dias 15/05/1912, 03/03/1913, 24/09/1914, 12/11/1915 e 05/12/1915 e SANTOS, 2009, p. 97- 137.

${ }^{48}$ FREHSE, 2000.

${ }^{49}$ TERRA, op. cit., p. 242.

${ }^{50}$ FREHSE, op. cit., p. 142-144.

${ }^{51}$ SANTOS, op. cit., p. 117-119 e TERRA, op. cit., p. 242.
} 
passavam a maior parte de seu tempo nas ruas, entre as calçadas e os leitos, ocupados com atividades de comércio e transporte, ou dedicados ao lazer das conversas e do botequim. Para as crianças, então, sempre mais vulneráveis, a diferença era discrepante: os pequenos dos palacetes possuíam jardins, cômodos próprios e centenas de brinquedos em suas casas, os mais pobres, tanto pelo exíguo tamanho de suas casas quanto pela cultura em que estavam inseridos, passavam o dia a brincar nas ruas ${ }^{52}$.

Como no caso do cancelamento de linha, a população vitimada não se resignava perante as tragédias. $\mathrm{O}$ crescente número de acidentes tornava simplória a explicação das fatalidades apenas pelo azar. Tomados pela indignação, exigiam justiça dos responsáveis, tendo como alvo ora os motorneiros, ora as companhias. Nas ocorrências, era comum ver ao redor dos bondes uma reunião de multidões, que não raras vezes partiam a resolver o infortúnio com as próprias mãos. Majoritariamente apontados como os principais responsáveis pelos acidentes, acometiam os motorneiros, que costumavam fugir do local, temendo a turba fervorosa ${ }^{53}$. No Rio de Janeiro, muitas dessas aglomerações acabavam assumindo as tempestuosas colorações dos motins. No frenético ritmo do "quebra-quebra", lançavam-se contra os carris, derrubavam postes e arrancavam os trilhos do leito ${ }^{54}$. A revolta silenciosa também se manifestava na população, que, como observara a redação d' $O$ Paiz, não era rebanho de carneirinhos, como muitos imaginavam. De acordo com o diário, os passageiros do bonde, respondendo a uma extorsão com outra, elaboraram um estratagema para burlar as companhias de transporte: um comprava um bilhete de ida e volta, mais barato do que dois avulsos, e passava o último a seu companheiro, que o entregava ao recebedor, que não tinha meios para comprovar a fraude ${ }^{55}$.

Longe de serem meras reações espasmódicas e irracionais, os motins e as falcatruas muitas vezes guardavam significados mais profundos de indignação. Como observou Paulo Terra, durantes os motins, não raro eram escutadas críticas e palavras de ordem

\footnotetext{
${ }^{52}$ Elaboraremos essa vida nas ruas das populações de baixa renda em nosso quinto capítulo.

${ }^{53}$ SANTOS, Op. cit., p. 97- 137.

${ }^{54}$ TERRA, Op. cit., p.243-252.

${ }^{55}$ O Paiz, 2 fev. 1899 apud TERRA, Op. cit., p. 244.
} 
contra os descalabros de governantes e as questionáveis relações que mantinham com as companhias de transporte $\mathrm{e}^{56}$.

Junto às manifestações nos jornais e a apresentação de abaixo-assinados, o ardil cotidiano e as convulsões de violência eram formas que os desprovidos de voto e outros meios de negociação e barganha encontravam para fazerem-se escutar pelas elites políticas e econômicas da cidade. Apesar de ainda não ter sido alvo de estudo específico, não há motivos para imaginar que em São Paulo tenha sido diferente. As agressões contra motorneiros eram cotidianamente registradas nas páginas do Correio, e em 1911, no Cambuci, após o atropelamento brutal de uma criança, foi organizado um comício contra os abusos da empresa canadense. Com a distribuição panfletária e a divulgação maciça da imprensa, a reunião no Teatro Independência congregou mais de mil pessoas, na sua maioria operários. Após o evento, a Prefeitura realizou uma perícia rigorosa nos veículos da Light, o que levou a imprensa a atribuir os desastres não somente à imperícia dos motorneiros, "à impaciência dos usuários, à desatenção dos pedestres, à falta de regramento das crianças ou aos limites físicos dos anciãos”, mas também à incompetência da empresa em garantir manutenção apropriada aos carris, bem como em elaborar um sistema adequado e seguro para a gestão do transporte. Assim, na própria cobertura da imprensa ligada às elites econômicas e políticas, vê-se que as contradições do cosmopolitismo começavam a aflorar, sendo o semblante progressista da Light complementado por sua face gananciosa e oportunista $^{57}$.

\footnotetext{
${ }^{56}$ TERRA, op. cit., p. 249-253.

${ }^{57}$ SANTOS, op. cit., p. 106-108.
} 


\section{Em pleno passeio, a velocidade acachapa os palacetes}

Outra contradita máquina moderna eram os automóveis. Já nas primeiras décadas do século XX, o invento cai nas graças da elite e dos mais abastados setores médios, até então os únicos com poder aquisitivo suficiente para adquirir os importados europeus e norte-americanos. Seu potencial ostensivo era tamanho ao ponto de o Automóvel Club ter-se tornado um dos pontos de encontro mais importantes do escol da elite paulistana ${ }^{58}$. Ao consumo conspícuo, somava-se o pulsante imaginário do Pós-Guerra, que segundo Sevcenko tem suas bases fundadas na profunda ruptura com o edifício civilizacional do "velho mundo", a "Europa que divide os homens pelo ódio", e a abertura para um "mundo novo" 59 . Nesse universo estreante, que passa a ter como centro irradiador os Estados Unidos - contrastando com o enaltecimento da família, do intelecto, da virtude e da ancianidade arraigados pela cultura burguesa da Europa oitocentista $^{60}$-, emergem como valores centrais o indivíduo, o dinamismo corporal e mental, a impetuosidade, a virilidade e a jovialidade $e^{61}$.

Essa cultura emergente, sem dúvida, foi um grande passo em direção às transformações comportamentais do século $\mathrm{XX}$, que terão seu ápice na década de 1960, além proporcionar aos indivíduos uma experiência de vida fascinante. Contudo, a experiência do automóvel, em certa medida ligada à vivência de liberdade dos jovens em relação às suas famílias, também possuía suas contradições.

Nesse contexto, a exibição automobilística, assim como a prática dos esportes, permitia uma imponente encenação de seu motorista. A máquina em si portava em sua materialidade as tão almejadas qualidades, desde o ronco do motor até sua lustrada carcaça, emprestando ao seu condutor uma fascinante moldura exibitiva, mobilizada especialmente nos celebrados corsos da Avenida Paulista, de algumas vias

\footnotetext{
${ }^{58}$ BRUNO, Ernani. Histórias e tradições da cidade de SP, p. 1249-50 apud SEVCENKO, Nicolau. Orfeu extático na metrópole: São Paulo, sociedade e cultura nos frementes anos 20. São Paulo: Companhia das Letras, 1992, p. 73-74.

${ }^{59}$ SEVECENKO, op. cit., p. 37-38.

${ }^{60}$ VALENCIANO, 2014; PROST, 1992; p. 21-61; PROST, 1992, p. 61-115; ARIÈS, 1978, p. 195-275 e CARVALHO, 2008, p.43-68.

${ }^{61}$ SEVCENKO, op. cit., 23-89.
} 
centrais, da Higienópolis e da Angélica, que nas palavras desdenhosas d'O Combate era o "local preferido para a exibição dos almofadinhas"62. O desprezo do jornal, que tinha como principais leitores os moradores do Brás, transcendia o bairrismo ou o preconceito de classe, pois não dizia respeito aos jovens que trafegavam lentamente, buscando os olhares e flertes das moças nas calçadas. Remetia antes ao que a imprensa, operária e de elite, denominara como "a mania de velocidade" ${ }^{63}$, que consistia numa tradução polida à moda excitante e perversa que tomava conta da juventude. Sob o título paradidático de "A lição da experiência", o jornal procurava transmitir uma clara mensagem ao seu leitor:

A lição da experiência! O lamentável desastre de ontem ocorrido no Jardim América e do qual damos mais abaixo circunstanciada notícia, deve servir de exemplo aos condutores de automóvel que, em desabalada carreira, circulam diariamente pela cidade. Esse desastre, no qual perderam a vida dois moços cheios de esperança, um deles profissional acatado, foi o resultado de uma imprudência manifesta, qual a imprimir à maquina uma excessiva velocidade, coisa que muita gente faz naturalmente, sem o menor respeito pela vida humana, com grave risco da sua própria vida.

Note-se que o desastre de ontem se deu num local onde há espaço para manobras difíceis, tanto que é escolhido para aprendizagem dos que pretendem conduzir automóveis. Entretanto, o que diariamente se constata é o abuso mesmo no perímetro central, onde o movimento é grande e os riscos são maiores.

Haja vista a própria rua Augusta, que os automóveis sobem e descem com velocidades que às vezes atingem à de 80 quilômetros à hora. Haja vista a Avenida Angélica, local preferido para a exibição dos almofadinhas que, em possantes 'voitures', atravessam aquela via pública como se estivessem numa pista de corridas automobilísticas.

É preciso que os srs. condutores de veículos, principalmente os 'moços bonitos' atentem bem para o caso que abaixo narramos, e que lhes deve servir de preciosa lição. A lição da 'experiência'... ${ }^{64}$

É apenas após essa prolongada introdução que a matéria prossegue ao ocorrido. A infeliz experiência dos rapazes fora tentar modificar o motor de um carro para conseguir imprimir-lhe maior velocidade. Ao testarem a engenhoca no Jardim América, contudo, furaram dois pneus e acabaram colidindo com uma árvore,

${ }^{62}$ O Combate, "A lição da experiência", 16 jan. 1924.

${ }^{63}$ SEVCENKO, op. cit., p.75-77.

${ }^{64}$ O Combate, "A lição da experiência", 16 jan. 1924. 
resultando o choque na morte instantânea da dupla. Essa campanha de conscientização dos perigos da velocidade, como notou Sevcenko, parece ter sido difusa na Imprensa, pois também fazia grande alarde em jornais como O Estado ${ }^{65}$. De acordo com as matérias analisadas pelo historiador, corria até mesmo a moda de divertir-se às custas dos presentes, sobre os quais jogavam propositalmente o carro! ${ }^{16}$

A correria na Angélica tinha sua motivação em sua topografia. Deitada sobre a encosta do Caaguaçu, era uma das ladeiras mais íngremes e extensas da expansão Oeste. Seu plano inclinado permitia ganhos inéditos de velocidade, que, naturalmente, fascinavam os motoristas. Mas a Angélica também atraía pela sua vitrine. Afinal, na maioria das vezes, as aventuras dos jovens guardavam fortes anseios exibicionistas. Contudo, diferentemente de seus pais, eles optavam por outras estratégias de simbolizar seu poder, dentre as quais a coragem e astúcia da velocidade automotiva ganhavam destaque ${ }^{67}$. Em um estranho movimento circular, a tão desejada vocação exibicionista da via ameaçava radicalmente seus anseios primevos. O palacete dos jovens eram seus carros, e em detrimento dos jardins, seus olhos voltavam-se ao que menos interessara às gerações anteriores: o leito carroçável da via. Assim, nos anos 1920, postos de gasolina passam a figurar na paisagem da Avenida ${ }^{68}$, consolidando a força arrojada dos motores passantes, a pá de cal na tão almejada, e nunca obtida, atmosfera de serenidade e comedimento que arbitrariamente as elites se esforçaram por estabelecer naqueles bulevares (FIG 36).

\footnotetext{
${ }^{65}$ SEVCENKO, op. cit., 75-77.

${ }^{66}$ Idem.

${ }^{67}$ Idem.

${ }^{68} \mathrm{Na}$ lista de impostos publicada pelo Correio Paulistano em 1928, vemos que à altura havia cinco bombas de gasolina na Avenida, ao menos em dois estabelecimentos distintos. Correio Paulistano, 9 mai. 1928.
} 

A bucólica passarela das elites 



\section{Três mundos... entrelaçados}

A conformação da Avenida Angélica foi resultado de uma tesa rede de disputas, significativa de um sinuoso e plural processo de modernização. Em seu ponto mais alto como vimos, agentes públicos e privados procuraram traçar uma fronteira, demarcando através de materialidades e representações espaços distintos para os mais e menos abastados. Contudo, como também observado há pouco, essa fronteira estava longe de configurar uma "muralha". Pelo contrário, sua consistência e espessura eram circunstanciais, variando de acordo com os agentes e seus errantes interesses, indo ao encontro da concepção dinâmica dos limiares sociais sustentada por Frederik Barth ${ }^{1}$. Assim, na fala dos próprios camaristas, a Angélica poderia figurar ora como uma via incólume, predestinada a conectar as mais belas vias da cidade; ora fraturada, quando eram sistematicamente negados os melhoramentos à sua parte superior.

Apesar desses estados antagônicos no âmbito institucional, sua vivência cotidiana parece ter sido menos extremada. No dia a dia, a fronteira superior conformava-se

\footnotetext{
${ }^{1}$ Aqui, a noção de fronteira foi mobilizada a partir de duas referências. A primeira é Frederik Barth, que aborda as fronteiras culturais como fenômenos dinâmicos, com alterações circunstanciais e motivadas pelos interesses de indivíduos e grupos em demonstrar distinção ou proximidade entre si. Para o caso em questão, o pensamento de Barth contribui com a percepção de que a fronteira não é uma entidade fixa e intransigente, mas um constructo social, com seu traçado e consistência constantemente modificados pelos diferentes grupos que habitam suas redondezas. BARTH, Frederik. Grupos Étnicos e suas fronteiras. In: POUTIGNAT, Phillip e STREIFF-FERNART, Jocelyne (org.). Teorias da etnicidade. São Paulo: Ed. Unesp, 2011, p. 188-227.
} 
como uma membrana porosa, através da qual ocorriam ambicionadas e indesejadas trocas. Veremos que, com seus corpos, práticas, materialidades e símbolos, os abastados, os remediados e os trabalhadores cruzavam seus universos com expectativas e interesses distintos, ora revelando percepções e práticas do urbano contrastantes, ora complementares, repercutindo nos mais variados resultados entre a associação, a tolerância e o conflito ${ }^{2}$.

A despeito da coexistência, a distribuição do poder de ação e representação era extremamente desigual entre os grupos que habitavam a Avenida. Sendo assim, no plano cotidiano, mesmo que permeado por disputas, foram os anseios das elites que tiveram maior força na consolidação de representações sobre a região, bem como na tomada de decisões a respeito de sua materialização. Mas os outros grupos, embora sujeitos à vontade dominante, permaneciam ativos e com iniciativa própria. Assim, ao passo que as elites consolidavam seus valores simbólicos, práticos e materiais na Avenida, os remediados e trabalhadores nesses se embrenhavam, deles se apropriando, algumas vezes procurando com eles harmonizar-se e, por outras, francamente subvertê-los ao sabor de seus próprios interesses.

Por fim, antes de seguirmos adentro dos caminhos que compunham os universos de cada grupo, vale lembrar que, para além do limiar que dividia as partes superior e inferior da Avenida, outras centenas de microfronteiras também se estendiam ao longo de seu trajeto. Em suas perpendiculares, bem como nas paralelas, habitavam os mais variados grupos sociais, produzindo em toda sua extensão a mesma rede de relações observadas em seu topo. A experiência de toda a Avenida, e muito provavelmente de todo o bairro de Higienópolis, era de uma ambígua homogeneidade heterogênea, regulada e matizada pelas diferentes mobilizações que se faziam de suas fronteiras. Para dar início à nossa incursão nas aspirações e ações que rodeavam a

\footnotetext{
${ }^{2}$ Esses dois estados extremos da fronteira correspondem ao que Richard Sennet, nossa segunda referência aqui, denominou boudaries e borders. A primeira remete aos espaços em que dois ou mais grupos estabelecem uma segregação total entre si. A outra, aos espaços em que, apesar da diferença seguir demarcada, ocorrem trocas e interpenetrações, funcionando como uma membrana porosa. A Avenida Angélica, como já vimos e o veremos ainda mais ao longo do texto, por diversas vezes oscilou entre esses dois polos e seus matizes, seja nas práticas cotidianas, seja nas ações institucionais, ou ainda em suas representações. SENNET, Richard. Boundaries and borders. In: BURDETT, Ricky e SUDJIC, Deyan (org.) Living in the endless city. Londres: Phaidon Press, 2011, p. 324-331.
} 
Avenida, tomemos como guia seus espaços primordiais: a casa e a rua. Dois âmbitos por vezes tratados como cindidos, mas que a nosso ver também eram delimitados por fronteiras circunstanciais, movediças e porosas, demandando que, para a apreensão completa de suas experiências e significados, seja necessário pensá-los em correlação (FIG. 37-40).

\section{Lar, agridoce lar}

As casas da alta sociedade, bem como dos mais abastados setores médios, eram concebidas como complexos artefatos, que por sua vez estabeleciam aspectos múltiplos em relação à rua. Seu aspecto representacional e simbólico, explorado por Maria Cecília Naclério Homem em O Palacete Paulistano, sem dúvida era fundante ${ }^{3}$, ainda mais para a conformação do espaço urbano ao seu redor, pois a exibição-visão de corpos, roupas e residências da alta sociedade eram atos extremamente meticulosos e ritualizados. Para corresponderem às expectativas de seus participantes, demandavam uma organização específica do espaço, que poderemos ver claramente em uma leitura mais apurada da espacialização proposta pela lei de recuos.

Nessa idealização de uma passarela, contudo, os desfiles eram bastante complicados. Compreendê-los exigiu-me aprofundar o incipiente instrumental analítico de Naclério, praticamente restrito à noção de status, concebido como um conjunto vago de demonstrações de riqueza e civilização. Exibir fortuna e modernidade certamente eram ações fundantes, porém havia muitas maneiras de fazêlo e, ainda mais, muitas maneiras de usos de seus emblemas no jogo social. Como nos interesses imobiliários, as elites também variavam em suas estratégias simbólicas. A modulação dos estratagemas estava intimamente relacionada com a peculiar posição social ocupada pelas famílias e indivíduos junto aos campos de disputa nos quais estavam inseridos. Nesse jogos, eram extremamente úteis os brasões da riqueza, mas

\footnotetext{
${ }^{3}$ HOMEM, 1996.
} 
também os ligados à adesão de ideários - como o cosmopolitismo ou o nacionalismo e a afirmação de identidades ${ }^{4}$.

Para além da esfera representacional, as residências das elites, bem como dos setores médios mais afortunados, contavam ainda com outras dimensões, desconsideradas por Naclério em seu trabalho. O mapa para essas outras entradas, encontrei na pesquisa de Vânia Carneiro de Carvalho, Gênero e Artefato ${ }^{5}$. Sua reflexão, evidente no título, centra-se nas relações de gênero perpetuadas e condicionadas pelos artefatos domésticos consumidos e apropriados pelos setores médios e abastados, em período semelhante ao nosso. Apesar do enfoque distinto, suas reflexões nos foram grandes guias em muitos aspectos.

A começar por sua penetrante arqueologia do ideário que dava sustento aos valores reinantes no ideal burguês de domesticidade, bem como suas implicações práticas no desenrolar da cotidianidade ${ }^{6}$. Para além disso, talvez mais valiosas sejam suas explorações das relações entre indivíduos e artefatos que transcendiam a esfera

\footnotetext{
${ }^{4}$ Minha principal referência e inspiração para essas interpretações foram as reflexões de Paulo Garcez sobre os casarões da Avenida Paulista (MARINS, 2016). Sobre o pensamento que embasava e fomentava a produção de tais discursos através da arquitetura, Eudes Campos explica que: "No final da Idade Clássica reconheceu-se a 'expressividade simbólica' da arquitetura por intermédio da teoria do 'caráter' dos edifícios, ou seja, à arquitetura era reconhecida a capacidade de transmitir ideias abstratas num nível acima de sua realidade material. À beleza da forma deveria sobrepor-se a 'beleza relativa', também chamada 'beleza de expressão', que é aquela que comunica ideias morais, sociais e intelectuais. De todos os tipos de arquitetura, segundo os teóricos, era a arquitetura doméstica que mais se prestava a expressar os sentimentos sociais e morais do homem. As concepções românticas sobre a arquitetura residencial defendiam, portanto, a ampla utilização do ecletismo tipológico-estilístico, afirmando haver sempre um estilo vernáculo ou histórico idôneo para cada tipo funcional de arquitetura doméstica, urbana ou campestre, e para cada tipo de temperamento e modo de vida do proprietário". CAMPOS, Eudes. Chalés paulistanos. Anais do Museu Paulista, v.16, n.1, 2008, p. 50.

${ }^{5}$ Parece-me importante reiterar o comentário realizado no primeiro capítulo a respeito da apropriação do trabalho de Carvalho. Apesar de definir seu objeto como "setores médios", grande parte das reflexões da autora estão centradas nas porções mais elevadas dessa heterogênea classe social. Ao ponto de que, muitas vezes, a autora remete a comportamentos e materialidades das elites como base para suas reflexões. Com isso, queremos apontar que entre os setores médios mais abastados e as elites, as fronteiras eram extremamente tênues e evasivas. Com certeza existiam, mas talvez em aspectos que não são relevantes, ao menos nesse momento, para o presente trabalho. Por isso, abordamos ambos os grupos conjuntamente, sob a alcunha de abastados ou simplesmente elites. E, por isso, nos apropriamos de grande parte das interpretações de Carvalho, a nosso ver, sem enganos, pois apesar das nomenclaturas distintas, parece-nos que suas reflexões são próprias ao grupo aqui abordado. Como setores médios, por sua vez, reconheceremos aqui aqueles que efetivamente possuíam capitais - sociais, econômicos e culturais -, poderes e privilégios bastante reduzidos em comparação aos mais abastados.

${ }^{6}$ Além de Carvalho (2008), aqui também foram fundamentais as já referenciadas pesquisas de Freire (1989); Valenciano (2014); Santos (2015) e Gay (2002).
} 
simbólica. Apoiada nas considerações de Ulpiano Bezerra de Meneses sobre cultura material, aqui também uma grande referência, a autora toma as materialidades como intermediadoras de relações sociais e como facilitadores na inculcação de práticas corporais e costumes culturais ${ }^{7}$. Noutras palavras, como os artefatos interagem na produção e reprodução dos habitus ${ }^{8}$. Esse caminho, que serviu a ela para explicar como a divisão de gênero era produzida e reproduzida no ambiente familiar, foi-me central para apreender outras relações que rodeavam a construção, decoração e ocupação de uma casa abastada. Afinal, parece simplório reduzir toda sua materialidade à mera busca de representações magnânimas de si mesmo. Da mesma maneira, parece ingênuo apreender, como o fizeram outros autores, a súbita avalanche de objetos que atulham suas casas - aparatos de conforto, decoração e entretenimento - como uma simples busca pelo bem-estar 9 .

Nesse sentido, dois autores me indicaram caminhos para pensar a relações do conforto doméstico através das funções mediadoras e inculcadoras apontada por Carvalho. A começar pela visão crítica de François Béguin, apresentada em seu texto seminal As maquinarias inglesas do conforto $^{10}$. A primeira grande lição de Béguin, embora ele não a explicite desta maneira, é que as estratégias de satisfação das classes sociais estão intimamente vinculadas com seus habitus. A posição social era mais marcada por limites do que possibilidades, geralmente amputando das classes mais baixas qualquer sonho de ascensão. Desapossados, tampouco tinham muito o que perder. Sendo assim, seu habitus era pouco aderente às rígidas restrições morais,

\footnotetext{
7 Ulpiano Bezerra de Meneses nos foi referência central para pensar a cultura material através dos seguintes trabalhos: MENESES, Ulpiano Bezerra de. Cultura material no estudo das sociedades antigas. Revista de História, São Paulo, n. 115, p. 103-117, 1985; MENESES, Ulpiano Bezerra de. Do teatro da memória ao laboratório da História: a exposição museológica e o conhecimento histórico. São Paulo: Anais do Museu Paulista, 1994, vol. 2, no 1; MENESES, Ulpiano Bezerra de. Memória e Cultura Material: documentos pessoais no espaço público. São Paulo: Revista Estudos Históricos, CPDOC/FGV, 1998, vol. 11, no 21; MENESES, Ulpiano Bezerra de. Prefácio. In: CARVALHO, Vânia Carneiro de. Gênero e Artefato: O Sistema Doméstico na Perspectiva da Cultura Material. São Paulo, 1870-1920. São Paulo: Edusp, 2008; MESENES, Ulpiano T. Bezerra de. Cultura material no estudo das sociedades antigas. Revista de História, São Paulo, n. 115, 1985, p. 113. Para as mencionadas reflexões específicas de Vânia Carvalho, cf. CARVALHO, 2008, p. 19-40.

${ }^{8}$ Para o leitor que chega agora, cf. a Introdução deste trabalho, na qual explico minha apropriação desse conceito a partir da teoria de Pierre Bourdieu.

${ }^{9}$ A exemplo de HOMEM, 1996 e LEMOS, Carlos A. C. Alvenaria burguesa. São Paulo: Ed. Nobel, 1986.

${ }^{10}$ BEGUIN, François. As maquinarias inglesas do conforto. Espaço e Debates nº 34, 1991, pp. 39-54.
} 
ansiosos desejos representacionais, domínio das noções de disciplina e estabilidade das outras classes. Da mesma forma, seu prazer também não lhes devia nenhum compromisso, o que levou as elites e o Estado a considerarem suas formas de satisfação como incivilizadas. Grande empenho foi mobilizado em desdenhar, rechaçar e ativamente mitigar tais formas de prazer, o que continha evidentes interesses por parte do Estado e dos empregadores. Quanto àqueles que não possuíam interesses diretos envolvidos na manutenção produtiva e ordenada dos trabalhadores, a adesão e reprodução de tais discursos difamatórios parecem mais uma reação defensiva de seus próprios habitus, que com representações pejorativas e juízos morais automatizados afastavam os indivíduos de sua sedução ${ }^{11}$. No âmbito do inconsciente, isso poderia ainda resultar de um clássico caso da inversão do amor em ódio, isto é, quando um desejo recalcado por um objeto é convertido em ódio contra o mesmo ${ }^{12}$. Não parece exagerado imaginar que parte da ferocidade dos ricos estava associada não só a anseios de controle, mas, inconscientemente, à inveja do desfrute de um modo de prazer e de vida conflitantes ou até mesmo interditos em seu habitus.

Sendo essas formas de prazer inconvenientes para a produtividade das fábricas, a reprodução do habitus e a ordenação social ansiada pelo Estado, os mais abastados chamavam-nas de viciosas, ou, nas palavras de Béguin, “conforto selvagem”. Para superar seu "custo social”, o sanitarista inglês Edwin Chadwick, em meados do século XIX, passou a conceber os aparatos de conforto doméstico como uma insidiosa forma de disciplinarização. Dizia que: "se o conforto é uma arma poderosa, é porque ele atinge uma forma de bem-estar que ninguém deseja nem tem meios de recusar"13.

Para além da disciplina, o conforto para Chadwick era uma forma de inculcar o habitus dos setores médios e altos no trabalhador. Vejamos a explicação através de suas próprias palavras:

\footnotetext{
${ }^{11}$ Para um aprofundamento no mecanismo defensor e autoperpetuador do habitus, cf. PETERS, 2009, p. 9-13.

${ }^{12}$ Refiro-me aqui à ideia de "inversão de conteúdo", um dos possíveis destinos dos desejos recalcados pelos indivíduos. Cf. FREUD, Sigmund. As pulsões e seus destinos. São Paulo: Ed. Autêntica, 2013; FREUD, Sigmund. A negação. São Paulo: Cosac Naify, 2014 e FREUD, Sigmund. O chiste e sua relação com o inconsciente. Rio de Janeiro: Ed. Imago, 2006. Para o uso do instrumental psicanalítico na análise histórica, nos baseamos na perspectiva proposta por Peter Gay em Freud para historiadores. GAY, Peter. Freud para historiadores. Rio de Janeiro: Ed. Paz e Terra, 1989.

${ }^{13}$ BEGUIN, op. cit., p. 48
} 
O marido vê sua mulher e sua família melhor instalados que antes, possui uma casa e um jardim mais agradáveis, isto o encoraja a trabalhar e, à medida em que ele se torna mais respeitável, torna-se consciente que tem alguma coisa a perder. Tendo adquirido certas vantagens, ele se preocupa em conservá-las e em melhorá-las ${ }^{14}$.

Para Chadwick, se fossem suficientemente atraentes, os lares poderiam atrair os homens a substituir o "conforto selvagem" pelos prazeres domesticados, como um jantar em família sob a aprazível atmosfera da calefação, um belo banho quente, o amor conjugal e uma boa noite de sono. Seu objetivo era, no duplo sentido da palavra, domesticar o homem através de prazeres que carregavam implicitamente a inculcação de pontos cruciais a habitus de sua classe: o casamento, a família, e, por fim, o culto ao trabalho. A insistência do sanitarista na necessidade de manter o homem dentro do lar e longe da rua explicita a centralidade da residência abastada na manutenção de seu habitus. Ter uma casa confortável era mais do que a busca pelo bem-estar, era uma condição sine qua non para a estruturação desse habitus. Sem o lar não se sustentavam as outras instituições. Como sustentar a rotina, a monogamia e a coesão familiar? O lar e o conforto não eram veleidades, não eram simples buscas pelo bem-estar: eram as portentosas fundações de um modo de vida.

A conversão pretendida por Chadwick residia na paradoxal conquista do "ter algo a perder". Para Chadwick, e mais amplamente para o habitus de sua classe, o trabalho era apenas um campo de virtude e de realização. A sensação de "ter algo a perder" é vista simplesmente como um impulso ao crescimento, uma motivação. Contudo, como vivenciavam os próprios setores médios e, em menor medida, os abastados, essa lógica continha uma perversa ambiguidade. Ter algo a perder significava ter medo. Um medo que levava o trabalhador ao encontro direto daquilo que eram duas das suas grandes fontes de tormento: a sofreguidão mental e física proporcionada pela intensidade da vida metropolitana e, sobretudo, pela tormentosa instabilidade de sua renda e vida laboral.

Sendo assim, se nos aparatos de conforto repousavam os maiores prazeres da modernidade, seu acesso, contudo, era mediado e atrelado à vivência profunda de seus

${ }^{14}$ CHADWICK, Edwin. Primeiro relatório dos comissários que investigaram a situação de grandes cidades e distritos populares, Londres, 1844 apud BEGUIN, op. cit., p. 48. 
dissabores. Uma contradição que não escapava aos olhos de alguns contemporâneos. Basta recordar que já em 1901, em As cidades e as serras, Jacinto vivencia profundamente a decepcionante descoberta da falácia por detrás da suprema máxima de sua própria autoria: "suma ciência mais suma potência igual à suma felicidade"15. Para gozar dos aparatos de conforto, devaneio e evasão era preciso acirrar a disciplina no trabalho. Fazendo-o, possivelmente, gerava-se maior cansaço, desgaste psíquico e exaustão emocional. Para superá-los, uma vez assumido o culto à produtividade, não se podia recorrer aos métodos "incivilizados", devia-se procurar aprimorar as satisfações que não interferissem na produtividade. Contudo, em sua maioria, estas eram adquiridas por meio do consumo: móveis, estofados, aquecedores, tapetes, livros. Sem falar que, para manter uma casa mais limpa, bonita e bem ordenada, tanto social como materialmente, era necessário sustentar a mulher ou contratar uma criada. Tudo exigia mais dinheiro, e mais trabalho. Não é difícil perceber a agonizante espiral em que era jogado o homem de pequenas posses que aderia ao habitus das elites e dos medianos mais abastados. Esse ciclo vicioso trabalho-consumo-conforto-trabalho, basal no habitus dos setores médios e abastados, guardava uma estreita ligação com um evento de escala global. Sem esse traço prático, a disseminação de indústrias na Europa e nos Estados Unidos em princípios do século XIX e a enérgica expansão do capitalismo internacional a partir da década de 1850 seriam impossíveis. Entre esses dois fenômenos - um micro, outro macro - não parece possível estabelecer uma hierarquia. São congênitos. Mutuamente estruturados e estruturantes. Figuravam como epicentros desses colossais abalos sísmicos, lado a lado, com equivalente

\footnotetext{
${ }^{15}$ QUEIROZ, Eça de. As cidades e as serras, 1901, p. 3 (Obra em domínio público). Disponível em: http://www.dominiopublico.gov.br/download/texto/bv000081.pdf (último acesso em fevereiro de 2017). Ao final da obra, Jacinto, em sua busca incessante pelo bem-estar, acaba encontrando maior prazer e conforto na vida campestre do que em meio à multidão de bugigangas que povoavam seu palacete parisiense. Sem dúvidas, a obra de Eça de Queiróz estava embebida de forte intenção românticonacionalista, embora Jacinto não se torne um bon sauvage, mas um burguês do campo. Contudo, paralelamente à crítica do culto à Paris e do desprezo dos portugueses por sua própria nação, não se pode deixar de levar em conta que de fato há uma crítica em colocar na balança os males e benesses advindos da vida moderna. Cf. COSTA e SCHWARTZ, 2000, p. 24 e RAMOS, Elvis Christian Madureira e FIGUEIREDO, W. "A cidade e as serras": uma relação dialética entre o homem e o espaço. Ciência Geográfica, Bauru, ano 15, vol. 15, jan./dez., 2011.
} 
importância, as magnânimas forças e escalas dos Estados e das grandes fortunas e o ordinário cotidiano de simples indivíduos ${ }^{16}$.

O tormento dos menos apossados inseridos no ciclo vicioso do conforto era sem dúvida tenebroso. Agora, não subestimemos o sofrimento também vivenciado pelos mais abastados. Mesmo que dificilmente violentados materialmente, a obsessão motora dos mais ricos era simbólica. Imersos no conflito de seu próprio universo social, não batalhavam por manter um meio de sobrevivência mínima e estável, mas sim por conquistar os mais altos postos políticos e econômicos da sociedade. Um anseio desenfreado e por vezes obsessivo, que, seguramente, lhes tornava atormentados como os menos remediados. Não à toa, à máxima açucarada das classes elevadas, "lar, doce lar", Peter Gay acrescentara o sabor desabrido e áspero do agro, do amargo e do azedo ${ }^{17}$.

O homem era o provedor da família. A ele, portanto, cabia a adesão ferrenha ao trabalho e aos negócios. No universo metropolitano, as oportunidades cresciam na mesma medida que a competitividade, ampliando drasticamente a carga psicoafetiva envolvida nos instáveis jogos de ascensão e descensão. Ao desgaste da labuta diária, somava-se a aceleração do tempo e o desnorteante avolumamento demográfico e espacial do Centro, que tornavam turvos e agitados os corpos e mentes que mergulhavam nesse novo caldeirão de experiência ${ }^{18}$. A luta diária no capitalismo exigia que todo dia as energias físicas e mentais fossem recobradas, para que no seguinte pudessem novamente alavancar a labuta.

As estratégias de descontração, contudo, não deveriam interferir na obstinação e na disciplina, portanto, deveriam ser contidas e apaziguadoras. Por isso, mesmo que por vezes recorressem às "pensões alegres" e aos clubs, o conforto dos abastados era predominantemente moderado, temperamento que não poderia encontrar espaço mais adequado do que a comunhão do lar. Assim, os mesmos homens que investiam e

\footnotetext{
${ }^{16}$ Afinal, o crescimento produtivo só é sustentável a longo prazo se houver consumo efetivo.

${ }^{17}$ Cf. GAY, 2002, autor original da potente e sintética imagem que qualifica esta seção: "lar, agridoce, lar".

${ }^{18}$ Boa medida dessa experiência pode ser notada no seminal escrito contemporâneo de Georg Simmel (1903) e no trabalho de Fraya Frehse sobre as interações nas ruas da cidade entre 1808 e 1907. Cf. SIMMEL, Georg. As grandes cidades e a vida do espírito. Mana, vol. 11, no. 2, Rio de Janeiro, Oct. 2005 e FREHSE, Fraya. Ô da rua: o transeunte e o advento da modernidade. São Paulo, Edusp, 2011.
} 
se favoreciam da metropolização ansiavam pela construção de herméticos abrigos contra esse atordoante universo, erguendo suas casas como templos ao resguardo psíquico, emocional e corporal ${ }^{19}$.

Daí a busca pelo bucolismo dos arrabaldes e pelo isolamento das edificações em meio ao lote, além da obsessão pelo gradil, manifesto explícito da rígida separação que procuravam estabelecer entre o público e o privado. O descanso e a descontração demandavam o controle, a segurança e o silêncio, incompatíveis com a agitação e a imprevisibilidade das calçadas. Sob o viés do conforto, a rua era depreciada pelas elites, servindo apenas de ligação e paisagem para os espaços privados, públicos e semipúblicos em que efetivamente encontravam seu agasalho ${ }^{20}$. Essa obsessiva repartição era projetada dentro dos próprios interiores, que se agigantavam para abrigar um maior número de atividades, mas também para viabilizar a sua máxima segregação. Para tanto, abusavam na construção de corredores, portas, escadas elementos de controle e segregação dos corpos, programados para evitar contatos e interferências indesejadas entre as áreas sociais, íntimas e de serviçco ${ }^{21}$. Observemos a casa de Sebastiana de Souza Queiroz, prima de Maria Angélica, e de Pedro Egidio de Queiroz Lacerda, seu marido (FIG. 40-42). A começar, a casa possuía duas entradas, que segregavam as chegadas de patrões e convidados da rotina dos empregados. Quem chegasse pelo acesso formal, toparia de imediato com um vestíbulo provido de cinco portas, que guardavam inúmeros arranjos possíveis. Para o patrão receber um cliente ou um amigo, bastaria abrir somente a primeira da lateral direita, conduzindo-o diretamente ao escritório. No caso de uma visita à senhora, abria-se somente a porta do salão ou da sala de música. Na ocasião de uma recepção mais ampla, abria-se o hall, donde depois seriam conduzidos os convivas diretamente à sala de jantar. O vestíbulo

\footnotetext{
${ }^{19}$ Cf. GAY, Peter, 2000; FRYKMAN, Jonas. Culture Builders: A Historical Anthropology of Middle-class Life. Nova Jersey: Rutgers University Press, 1987, p. 127; CARVALHO, 2008, p. 43-67. Novamente, presto aqui referência às aulas e interlocuções mantidas com a Profa. Joana Mello de Carvalho e Silva durante os últimos três anos, fundamentais para a apreensão deste e de tantos outros pontos desenvolvidos a seguir neste capítulo. Reflexões que foram sintetizadas em grande parte em nosso artigo conjunto, ainda inédito: SILVA, Joana Mello de Carvalho e FERREIRA, Pedro Beresin Schleder. Os sentidos do morar em três atos: representação, conforto e privacidade.

${ }^{20}$ Nas residências - reuniões, chás, festas, jantares, sinuca, carteado, leitura, piano - e no Centro da cidade - os clubes, cafés, teatros, lojas, passeios nos jardins públicos, etc.

${ }^{21}$ HOMEM, 1996, p. 113-182.
} 
distribuía eficazmente os fluxos, ritualizando as fronteiras internas da casa de maneira que os moradores e convidados não ousassem adentrar os espaços em que não fossem requisitados. O mesmo esquema se repetia ao longo da casa: a área de serviços era isolada, conectada apenas à sala de jantar; para a circulação interna de patrões e empregados, havia duas escadarias segregadas; o primeiro andar era reservado à vida pública e o segundo, à intimidade, e assim por diante $\mathrm{e}^{22}$.

Embora na casa houvesse cômodos específicos para a descontração masculina - o escritório, o fumoir e o bilhar -, suas exigências de conforto perpassavam praticamente todo o interior doméstico. Com exceção das salas de recepção, às quais nos ateremos adiante, os outros ambientes eram modelados de forma a compor cenários introvertidos e agradáveis. As cortinas dosavam a luz e afastavam as informações externas, criando uma atmosfera aconchegante, complementada pelo brando tato das tapeçarias e dos acolchoados que revestiam a mobília. Os materiais e tonalidades dos revestimentos seguiam o tom da amenidade, portando quadros, papéis de parede e afrescos com temas pitorescos induziam à tranquilidade, ao devaneio e ao bem-estar. Conveniência e afabilidade que deveriam ser seguidas também pelos filhos e pela esposa, a quem cabia domesticar suas emoções e seu comportamento de maneira a evitar o confronto e o desprazer do patriarca ${ }^{23}$.

Essa redoma de conforto também se destinava ao abrigo de outros membros da família das mazelas metropolitanas. Preocupados com a formação moral e cultural de seus filhos, muitos abastados optavam pela educação doméstica, realizada por professoras ou preceptoras, comumente de origem europeia. Como já vimos, a própria vida doméstica, principalmente para as meninas, era pensada de maneira propedêutica. Junto às mães, aprendiam os afazeres da casa, a combinação de roupas e maquiagem e se iniciavam na alta cultura, instrumentos essenciais para a conquista de seu fundamental objetivo: um bom casamento. Eis a instituição central do habitus

\footnotetext{
${ }^{22}$ A escadaria de serviço não consta na planta aqui apresentada, porém está presente na casa construída, existente até hoje, sede atual do IPHAN-SP. O mesmo esquema distributivo pode ser observado até com mais clareza na planta da residência de Aureliano Gusmão (FIG 56-57).

${ }^{23}$ MALTA, Marize. O olhar decorativo: ambientes domésticos em fins do século XIX no Rio de Janeiro. Rio de Janeiro: Mauad X: Faperj, 2011, p. 49; CARVALHO, 2008, p. 276-285; SANTOS, 2015, p. 56-87.
} 
feminino, que estava por detrás de uma faceta ambígua do aconchego doméstico, que, sob certas medidas, convertia a casa em uma prisão confortável para as mulheres ${ }^{24}$.

Distante da realização pessoal, nos casamentos abastados ainda predominava a noção de contrato. Através dele, famílias e clãs estabeleciam laços e alianças de poder econômico, simbólico e político -, sendo o matrimônio uma importante estratégia em seus ambiciosos anseios de escalada social. Contudo, em uma sociedade organizada, ao menos na aparência, por um intransigente puritanismo, a garantia de uma boa aliança estava intimamente relacionada à pureza feminina, que só poderia ser garantida mediante o severo controle da vida social e das companhias ${ }^{25}$. Assim, desde cedo, as jovens raramente estavam sozinhas, sequer nos momentos de maior intimidade, como o banho, quando poderiam ser vítimas das infames descobertas do próprio corpo ${ }^{26}$. A ocultação do sexo também tomara forma arquitetônica, garantida pelo isolamento do quarto do casal, a individuação das camas e a segregação de quartos masculinos e femininos para a prole. A rua lhes era terminantemente proibida e, quando recebida a autorização paterna, a saída era sempre mediada pela presença de uma companhia, que exercia o duplo papel de camarada e vigia. Juntamente com suas mães, cuja honra e fidelidade eram também arduamente encasteladas, viviam grande parte de suas vidas trancafiadas em casa. Para que assentissem com uma vida reinada pela restrição, era necessário que encontrassem na casa divertimento, além de prazeres devidamente domesticados ${ }^{27}$.

Daí a importância da inculcação do amor materno, chave do habitus feminino e largamente promovida pelas instituições médicas e intelectuais, que atrelaram terminantemente a satisfação feminina ao cuidado da casa, da prole e do marido ${ }^{28}$. Junto às filhas, as mães encontravam o deleite na ordenação e composição decorativa, nas tarefas de arrumação, no consumo, nas pequenas artesanias e no mergulho

\footnotetext{
${ }^{24}$ Cf. CARVALHO, 2008, p. 291-302; SANTOS, ibidem e CORBIN, Alain. O segredo do indivíduo. In: PERROT, Michelle (org.). História da vida privada: da Revolução Francesa à Primeira Guerra. São Paulo: Companhia das Letras, 1992, p. 419-502.

${ }^{25}$ FREIRE, 1989, p. 255-271.

${ }^{26}$ CORBIN, op. cit., p. 436-455 e GAY, Peter. A educação dos sentidos. São Paulo: Companhia das Letras, 1999, p. $87-127$.

${ }^{27}$ CORBIN, Ibidem.

${ }^{28}$ FREIRE, Ibidem e SANTOS, Ibidem.
} 
contemplativo e evasivo das artes ${ }^{29}$. Não à toa Edmond de Goncourt atribuíra ao piano - “o haxixe das mulheres" - o estatuto máximo da intoxicação no universo feminino. Diferentemente dos homens, eram restritas suas estratégias para lidar com os sentimentos e desejos frustrados ${ }^{30}$. Por isso, por vezes encontravam brechas para subverter o restrito esquema de prazer que lhes era concedido. A alienação sexual dava ao quarto, por exemplo, uma redoma de privacidade ausente em qualquer outra parte da casa. Ali, as meninas podiam driblar os controles internos e externos e aventurar-se nos reinos secretos da mente e do corpo, através da própria imaginação ou da indução do deleite erótico encontrado na leitura de livros "proibidos" ou na troca de cartas libidinosas com seus amantes ${ }^{31}$. Ademais, há de terem sido inventadas outras centenas de engenhosas estratégias de contorno e subversão, ainda indisponíveis para nós apenas pela carência de um estudo mais aprofundado.

\section{"Dize-me como moras, dir-te-ei quem és" 32}

Ao passo que domesticava, no duplo sentido da palavra, o conforto também guardava uma outra faceta, ligada a uma função destinada prioritariamente à mulher no casamento: a representação. Diante de um mundo em que, cada vez mais, tudo o que era sólido se desmanchava no ar, a manutenção de profícuos e poderosos laços

\footnotetext{
${ }^{29}$ CARVALHO, Ibidem.

${ }^{30}$ CORBIN, op. cit., 486-501.

${ }^{31}$ Cf. GAY, 2002.

${ }^{32}$ Tal máxima advém da sagacidade de Machado de Assis em sua obra Linha reta e linha curva (1870), na qual ele narra a seguinte cena: "Emília morava com uma tia velha. Era uma boa senhora, amiga da sobrinha, e inteiramente escrava da sua vontade. Isto quer dizer que não havia em Emília o menor receio que a boa tia não assinasse de antemão. Na sala em que Tito foi recebido não estava ninguém. Ele teve portanto tempo de sobra para examiná-la à vontade. Era uma sala pequena, mas mobiliada e adornada com gosto. Móveis leves, elegantes e ricos; quatro finíssimas estatuetas, copiadas de Pradier, um piano de Erard, tudo disposto e arranjado com vida. Tito gastou o primeiro quarto de hora no exame da sala e dos objetos que a enchiam. Esse exame devia influir muito no estudo que ele quisesse fazer do espírito da moça. Dize-me como moras, dir-te-ei quem és." ASSIS, MACHADO. Linha reta e linha curva, 1870, p. 20. (Obra em domínio público). Disponível em: http://www.dominiopublico.gov.br/download/texto/bv000176.pdf (último acesso em fevereiro de 2017)
} 
sociais dependia da capacidade de manter constantes e atualizadas suas apresentações de bom gosto e refinamento. Apesar do homem também cumpri-lo à sua maneira, o empenho cotidiano era realizado pelas esposas na assiduidade aos eventos públicos e da alta sociedade, no comparecimento a festas e cerimônias, na organização de caridades, no empenho em ler e escrever cartões, no compromisso de dar e receber visitas e na coordenação das recepções domésticas, como o chá, o almoço, o petisco e o jantar ${ }^{33}$.

Nesse rol de tarefas e ritos, encontramos a contraditória inspiração da burguesia francesa nos ritos de afirmação e de entrelaçamento social da aristocracia setecentista, que também se faziam presentes em território nacional ${ }^{34}$. Enquanto a rotina masculina era perpassada prioritariamente pela continuidade metódica do trabalho burguês, o cotidiano feminino assemelhava-se à vida de escol, simulando o tempo brando e ocioso das aristocracias europeias ${ }^{35}$. A possibilidade dessa rotina em si já era grande demonstração de poder, pois denotava a fortuna profissional ou comercial do marido, que era capaz de sustentá-la ${ }^{36}$. Nessa mesma lógica, ao passo que deveria acolher o descanso masculino, a casa também deveria ser arquitetada como palco para a vida fidalga feminina: um elegante e imponente mostruário das qualidades morais, econômicas e culturais da família ao mundo. Afinal, eram palacetes e não meros bungalows confortáveis, alocados de qualquer maneira em uma área suburbana. Em contraste com o resto da casa, as salas de recepção eram decoradas de forma a produzir o ânimo jubiloso e solene apropriados ao encontro social. A redoma de suntuosidade pairava sobre todos os objetos, desde a pintura das paredes até os

\footnotetext{
${ }^{33}$ CARVALHO, 2008, p. 219-240.

${ }^{34}$ MARINS, 2011, p. 229.

${ }^{35}$ Contudo, apesar de fortemente centrada no trabalho, é patente que entre os homens das mais elevadas elites a rotina possuía grande flexibilidade, podendo, por exemplo, abarcar suas extensas temporadas na Europa ou no litoral. MARINO, Carlos Eduardo Collet. O ócio e o lazer na São Paulo da Belle Époque: a vilegiatura marítima e a invenção do Guarujá enquanto balneário da metrópole (1890-1915). Relatório de Qualificação de Mestrado, FAU-USP, São Paulo, 2016.

${ }^{36}$ CARVALHO, Ibidem.
} 
detalhes da mobília. A ostentação de riqueza e sofisticação era tamanha que muitos desses cômodos chegavam a receber a alcunha de "salões dourados"37(FIG. 43-46).

A ambivalência da comodidade e da exibição também delineava a conformação externa da casa. Parte da arquitetura era desenhada de dentro para fora, procurando satisfazer a geometria e a proporção adequada para cada ambiente, bem como chegar a uma boa medida de ventilação e insolação. Desse desenho, resultava grande parte das assimetrias e movimentações do volume final ${ }^{38}$. Ao mesmo tempo, o projetista concebia o edifício por fora, procurando dar-lhe a coerência e a expressividade de um objeto artístico, conveniente aos anseios de seu futuro proprietário. Essa faceta da residência acabava por contaminar os significados da rua, que se era aparentemente vazia em sentido de conforto, assumia papel fundamental para a sustentação de um dos pilares fundamentais do arcabouço cultural das elites: a exibição-visão.

No emergente mapa da sociabilidade na cidade, a Avenida Paulista e a Higienópolis, bem como algumas vias centrais ${ }^{39}$, além de articularem espaços de sociabilidade ostensiva, eram promovidas à posição protagonista nos ritos de exposição. Importantes atividades do lazer das elites nas primeiras décadas do século XX eram realizadas em seu domínio: o footing, a apreciação dos corsos, as batalhas de confete dos carnavais, bem como as caminhadas flanantes pela cidade, cujo percurso mais famoso se dava no triângulo central. Nessas ocasiões, as ruas eram convertidas em passarelas, por onde as madames e mademoiselles, seguidas por senhores e rapazes, tinham a oportunidade de exibir publicamente seus corpos sadios - um valor crucial em um mundo sob a égide doutrinária do higienismo -, bem como suas melhores vestes e adereços, ostentando a educação e a pujança de suas famílias, bem como o portento de seus dotes matrimoniais.

Esses três espaços da sociabilidade abastada - Paulista, Higienópolis e Triângulo eram conectados pela Avenida Angélica. Portanto, não é de se estranhar que na

\footnotetext{
${ }^{37}$ Cf. HOMEM, 1996 e SILVA, Joana Mello de Carvalho; FERREIRA, Pedro Beresin Schleder et al. A residência Franco de Mello em três tempos: da domesticidade belle époque ao Centro de Cultura, Memória e Estudos da Diversidade Sexual do Estado de São Paulo. Revista CPC, n. 20, 2015.

${ }^{38}$ RICE, Charles. The emergence of the interior: architecture, modernity, domesticity. London: Routledge, 2007.

${ }^{39}$ A exemplo das Ruas XV de novembro, Direita e São Bento, analisadas por BARBUY, 2006.
} 
concepção de Burchard e Nothmann predominasse a ideia de exposição, bem como na ação de Cardim e Telles, que apresentaram evidente desproporção na preocupação estética da Avenida Circular em detrimento de seu funcionamento técnico ${ }^{40}$. Nesse sentido, a dupla alemã não só preocupou-se em dotar a via inteira de arborização, tornando-a um lugar aprazível para o passeio, como procurou convencer a Câmara a proibir a passagem de gado pelas vias do Boulevard, visando não só a preservação da arborização, mas também o apaziguamento de seu movimento ${ }^{41}$. Pacificação que se buscava igualmente com a promoção da exclusividade, que evitaria que a rua fosse ocupada pelos hábitos de permanência e sociabilidade da rua dos trabalhadores, antagônicos aos anseios de limpeza e exibição cultivados pela alta sociedade. Contudo, o pedido foi negado pela Câmara, assim como foi frustrado o anseio de exclusividade, o que dificultou, porém não impediu, que a passarela fosse colocada em prática.

Para além de corpos e adereços, aspirava-se na Avenida a exposição-visão de residências e jardins. Desde meados de 1860, com a elevação de casarões neoclássicos na Luz, a morada dos prósperos paulistanos passa a ser concebida como residênciamonumento ${ }^{42}$. Inspiradas em um primeiro momento nos hôtels privés da aristocracia francesa setecentista e depois nas residências suburbanas da burguesia parisiense do XIX, essas construções transformavam radicalmente o decoro classicista até então em vigor na cidade. Isso porque elevavam a edificação privada à monumentalidade antes exclusiva aos edifícios públicos e religiosos, rompendo com a gramática urbana que limitava a essas instituições públicas e religiosas as posições recuadas e ajardinadas, destacadas das fileiras uniformes que até então regiam as obras particulares ${ }^{43}$.

No âmbito arquitetônico, aproximavam-se em altura, volume, plasticidade e expressão das edificações oficiais, chegando ao cúmulo de uma residência como a Vila Penteado, na época de sua inauguração, poder competir em suntuosidade com o

\footnotetext{
${ }^{40}$ Sobre a centralidade da ideia de exposição nas transformações sociomateriais do Centro de São Paulo da virada do século XX, Cf. BARBUY, 2006.

${ }^{41}$ Atas da Câmara da Cidade de São Paulo, 1891, vol. 77.

${ }^{42}$ CAMPOS, Eudes de Mello. Arquitetura paulistana sob o Império: aspectos da formação da cultura burguesa em São Paulo. Tese (Doutorado) - FAU-USP, São Paulo, 1997 e CAMPOS, 2005.

${ }^{43}$ Para mais informações sobre o decoro que guiava a materialidade urbana no território nacional ao menos desde o século XVIII, cf. BASTOS, Rodrigo Almeida. O urbanismo conveniente luso-brasileiro na formação de povoações em Minas Gerais no século XVIII. Anais do Museu Paulista. 2012, vol. 20, n. 1.
} 
Palácio do Governo, ainda localizado no Largo do Palácio. Uma inversão de decoro que tem seu ápice expresso na transposição da sede do Governo do Estado, em 1912, para a antiga residência de Elias Antônio Pacheco Chaves, evento que evidencia o equiparo de poderes simbólicos, e por muitas vezes práticos, em que se encontravam os setores público e privado na definição dos rumos da cidade. A subversão da gramática urbana vigente possuía grande potência simbólica: ao equiparar obras privadas à grandiloquência do Estado, as elites elevavam sua posição, ao menos simbolicamente, à altura de uma instituição, como eram, de fato, as aristocracias europeias setecentistas. Não à toa, essas residências, que eram monumentos ao poder e riqueza de seus proprietários, receberam em solo nacional a denominação de palacetes, em associação direta aos palácios dessa fidalguia, e também à morada dos governantes em terra nativa (FIG. 47-50).

A aproximação das elites nacionais de hábitos, costumes, nomenclaturas e materialidades da fidalguia merece um breve comentário, tendo em vista que a dualidade entre aristocracia e burguesia não se fazia presente em solo nacional. Por aqui, as elites locais ocupavam posições ambivalentes na política e na economia, levando à apropriação simbólica e simultânea de ambos os universos sociais. Visando o engendramento de uma posição de indubitável elevação hierárquica, bem como de distinção das elites imigrantes, como a que desfrutavam os nobres da Europa ocidental até a Revolução Francesa, as elites locais empenhavam-se em forjar uma série de signos e discursos que constituíssem para si uma narrativa de tradição, honra e nobreza ${ }^{44}$. Contudo, apesar de seu afinco à terra nativa, essa mesma nata estava ligada às ondas cosmopolitas dos costumes burgueses, do republicanismo, do mercado internacional e da industrialização e reivindicava a si mesma representações ligadas a essas práticas e ideários ${ }^{45}$.

\footnotetext{
${ }^{44}$ MARINS, 2011, p. 229.

${ }^{45}$ Não por acaso, a construção do mito bandeirista nas primeiras décadas do século XX, que teve papel central no empenho de enobrecimento desses grupos, apresentava uma narrativa na qual, apesar de congênito à terra, seu protagonista tendia in natura ao progresso e à civilização. Sobre essa narrativa, cf. FERREIRA, Antônio Celso. A epopeia bandeirante: letrados, instituições, invenção histórica (1870-1940). São Paulo: Editora UNESP, 2002.; FUNARI, Pedro Paulo Abreu. A cultura brasileira e a construção da mitologia bandeirante. In: Ideias, ano 2, n. 1, Campinas, UNICAMP, 1995.
} 
Essa representação ambivalente se estendia às toponímias da cidade, notadamente em Higienópolis. Em jornais como O Correio Paulistano e O Estado de São Paulo, ambos ligados a famílias da alta sociedade local, os bairros da região sudoeste recebiam a alcunha de aristocráticos, adjetivo que por vezes deslizava para caracterizar suas principais vias, como as avenidas Angélica e Higienópolis. Contudo, em Higienópolis, esse epíteto cruzava com símbolos cosmopolitas, a exemplo de seus seguidos batismos: o Boulevard Burchard, que aproximava a região dos espaços exclusivistas da burguesia parisiense, e o nome atual, que glorificava um valor sanitarista, partícipe central no universo simbólico dessa mesma burguesia. Sem falar dos nomes que levavam suas vias. Em sentido leste-oeste, figuravam estados nortistas - Maranhão, Piauí, Alagoas, Sergipe, Pará -, e na transversal, três grandes picos de Minas Gerais - Itambé, Itacolomi e Itatiaia. A união simbólica dos estados mais distantes do Norte com o Sul presente representava um tributo à recém-fundada República, acrescido pelos picos de Minas Gerais, que, ao costurar as vias dos Estados, parecem homenagear o papel preponderante atribuído aos Inconfidentes na narrativa laudatória do novo regime ${ }^{46}$. Assim, as elites de Higienópolis, ao passo que moravam em palacetes de um bairro aristocrático, ostentavam igualmente os valores da burguesia, ambivalência que lhes permitia grande flexibilidade identitária, largamente mobilizada na ação e representação particular de seus membros ${ }^{47}$.

Voltando ao horizonte nobilitante e magnânimo da residência-monumento, vejamos a materialidade proposta pela lei de recuos para a Avenida Angélica. Até o momento, nos ativemos apenas à sua dimensão excludente, porém, os dois metros

\footnotetext{
${ }^{46}$ As apologias ao regime republicano apareciam também em outros espaços da região, como a Rua XV de Novembro, a Praça da República, entre outros. Uma outra união simbólica da federação em um território através de suas toponímias ocorria, de maneira ainda mais potente, em simultaneidade ao arruamento de Higienópolis: a noemação das vias centrais do plano de Belo Horizonte, iniciado em 1894. Para uma análise detida do simbolismo republicano contido nessa empresa, Cf. SALGUEIRO, Heliana Angotti. Figures de la patrie: la symbolique de l'éspace republicain. In: La casaque d'Arlequin: Belo Horizonte, une capitale écletique au 19e siècle. Paris: Editions de l’EHESS, 1997, p. 103-118. Para a centralidade simbólica dos Inconfidentes, principalmente Tiradentes, no discurso apologético ao novo regime durantes os primeiros anos da República, cf. CARVALHO, José Murilo de. A formação das almas: o imaginário da República no Brasil. São Paulo: Companhia das Letras, 1990.

${ }^{47}$ Conferir, por exemplo, as ambíguas táticas de representação empregadas por Joaquim Franco de Mello, analisadas em SILVA, FERREIRA, et al. 2015 e as sinuosas trajetórias práticas e representativas dos Silva Prado em LEVI, Darrel. A família Prado. São Paulo: Cultura 70, 1977.
} 
laterais e seis metros frontais também fixavam específicas orientações construtivas e, sobretudo, de apreciação do construído. Ao passo que as residências de elite começam a ser concebidas simultaneamente como habitat, obra de arte e discurso público, o espaço da rua tem sua formulação também alterada, passando a ser pensado como o recinto de apreciação dessas obras. A modelagem dos recuos, para além de seus benefícios sanitários, concebia uma via onde a separação entre as edificações era garantida pelos afastamentos laterais, permitindo que cada uma desenvolvesse sua própria linguagem e discurso sem mediações estéticas ou conflito direto com as enunciações vizinhas ${ }^{48}$. Juntamente com a consequente ampliação dos lotes, decorrente de suas restrições construtivas, os recuos padronizados possibilitavam uma variedade dentro de uma unidade, valor largamente defendido como "uma das melhores definições do Belo” por Leónce Rynaud e César Daly, figuras de destaque no pensamento de engenheiros e arquitetos brasileiros da época. Assim, atingia-se simultaneamente a beleza da ordem, reforçada pela retilínea e constante arborização da via, e do inusitado, compondo, nas palavras de Daly, le pittoresque harmonieux ${ }^{49}$.

Procurava-se com o edifício isolado em meio ao lote efeito semelhante ao do pedestal para as esculturas nos museus: colocar a obra em evidência através do destacamento de seu contexto. Os recuos frontais, para além de libertar o prédio da retitude do alinhamento, asseguravam distância para sua boa admiração. Cada vez mais magnânimas, as obras passavam a ter escala vertical e desenvolvimento volumétrico que dificilmente poderiam ser apreciados se colocadas ao rés da guia. $\mathrm{O}$ planejamento visual da Avenida, assim, era semelhante ao de uma exposição. Sua experiência ficava entre a apreciação contemplativa de um museu e o descontraído deambular pelas vitrines do Centro. Meio espectador, meio voyeur materialista, o passeio pretendia oferecer ao caminhante a beleza e a ostentação das palacianas construções, meio obras de arte, meio mercadorias ${ }^{50}$. Um plano que, como veremos,

\footnotetext{
${ }^{48}$ Sobre o sentido higiênico dos recuos, cf. LEMOS, 1999; Lemos, 1986 e CORREIA, 2004.

${ }^{49}$ SALGUEIRO, 1997, p. 384-385.

${ }^{50}$ Quando me refiro aqui a mercadoria, estou remetendo a todos os serviços, objetos e materiais que eram consumidos para a construção do edifício e que, ao menos para os olhares treinados na alta cultura, exibiam-se não apenas como beleza, mas também como poder monetário.
} 
teve sucesso pleno apenas em alguns trechos da Angélica. Talvez por isso, diferentemente da Paulista e da Higienópolis, não tenha conhecido a fama fotogênica, restando a nós contemplar seu ideal de visualidade através das fotos destas duas avenidas (FIG. 51-52).

Apesar de suas atrações estarem contidas na mesma categoria - o palacete -, o espetáculo da Angélica apresentava obras extremamente variadas. Em cada uma, o fausto, a riqueza e a ostentação eram moduladas de acordo com as estratégias representativas de seus proprietários, as quais, por sua vez, correspondiam às suas nuances sociais e temporais. Maria Cecília Naclério Homem, tanto em seu trabalho sobre Higienópolis (1980) como em O Palacete Paulistano (1996), apesar de anunciar algumas dessas distinções, não as sublinha como um dado importante para a compreensão do espaço das elites, priorizando a concepção harmônica e coesa desse universo. Como já observado no capítulo anterior, é fundamental apreender as relações entre as elites em sua movediça e, por vezes, sutil ambiguidade. Os palacetes enfileirados, ao mesmo tempo em que sinalizavam unidade em contraposição aos outros segmentos sociais, carregavam também elementos de contrariedade e competição. Páreo que se anunciava na Angélica pela busca de proeminência ostentatória entre as famílias do círculo nacional - uma corrida incessante pela residência mais sofisticada, mais bela, mais vultosa -, bem como na disputa simbólica entre imigrantes e nativos, à maneira da Avenida Paulista analisada por Paulo Garcez, e, a partir de meados da década de 1910, na contenda estética entre as tendências socioestéticas do neocolonial e dos cosmopolitismos ${ }^{51}$.

Entre as elites locais, em consonância à estratégia de ambígua inserção representativa há pouco descrita, não foram raros os casos em que foram encomendadas réplicas miniaturizadas de palácios das mais variadas aristocracias europeias. A começar pela residência de Maria Angélica de Sousa Queiroz Barros, construída por Augusto Fried, um engenheiro alemão radicado na cidade, em 1891. De acordo com relatos colhidos por Maria Cecília Naclério Homem, através de planos, materiais e decoração encomendados diretamente da Alemanha, a matriarca procurou

\footnotetext{
${ }^{51}$ MARINS, 2016.
} 
replicar o Palácio de Charlottenburg, obra que até meados do século XIX serviu de morada à dinastia reinante na Prússia, passando a servir em seguida ao trono do recém-criado Império Alemão ${ }^{52}$. Apesar de não haver motivo aparente que explique a predileção pelo palácio germânico, não há dúvidas que, para o propósito de autonobilitação, tratava-se de uma eleição de grande efeito. Ainda mais se considerarmos que a residência foi construída antes do loteamento de seus arredores, assimilando-se na inserção paisagística e urbana aos paços das tão admiradas cortes setentrionais.

Trinta anos depois, na década de 1920, a estratégia prevalecia. Na altura, Oscar Rodrigues Alves, filho do ex-presidente Francisco de Paula Rodrigues Alves, constrói sua residência praticamente na esquina da Avenida Higienópolis com a Angélica. Até 1911, Oscar teve grande parte de sua trajetória dedicada à pesquisa e ao exercício das ciências médicas, e foi um dos grandes incentivadores da criação da Faculdade de Medicina de São Paulo, ao lado de Arnaldo Vieira de Carvalho e Altino Arantes ${ }^{53}$. Após o grande feito, abandona a medicina e passa a dedicar-se integralmente à política, ocupando cargos executivos e legislativos com base no Partido Republicano Paulista $^{54}$. A mudança de curso sem dúvida intensificou as ocasiões ritualísticas de seu cotidiano, bem como o empenho em seu esforço representativo. Não à toa, ao encomendar sua morada, menospreza referências à sua formação positivista, optando por construir uma semiduplicata do Petit Trianon $^{55}$, priorizando a ênfase em sua “nobreza" (FIG. 52-53).

No espaço interno dessas residências, o esforço nobilitante também se manifestava. A vultuosidade das "salas douradas" remetia diretamente às carregadas decorações ostentadas nos palácios da dinastia Bourbon. Não à toa, sua decoração era invariavelmente concebida

\footnotetext{
${ }^{52}$ HOMEM, 1980, p. 44.

${ }^{53}$ Dados obtidos a partir do verbete “Oscar Rodrigues Alves” no Dicionário de verbetes biográficos do CPDOC-FGV. Disponível em: http://www.fgv.br/cpdoc/acervo/dicionarios/verbete-biografico/alvesoscar-rodrigues (último acesso em fevereiro de 2017).

${ }^{54}$ Foi secretário da presidência de São Paulo de 1912 a 1916 e secretário dos Negócios do Interior de 1916 a 1920. Membro do Partido Republicano Paulista (PRP), foi senador estadual em São Paulo de 1922 a 1930, tendo integrado a Comissão de Higiene e Instrução Pública. Ibidem.

${ }^{55}$ Notório por ter abrigado, no século XVIII, Madame du Barry, uma das amantes de Luis XV e, posteriormente, por ter servido de morada a Maria Antonieta, esposa de Luis XVI.
} 
nos estilos que levavam o nome de seus consagrados monarcas - Luis XIV, Luis XV e Luis $\mathrm{XVI}^{56}$. Na composição arquitetônica, a elevação dos pés-direitos procurava amplificar a sensação de magnitude, que era singularmente aproveitada por um inusitado elemento: a escadaria. Como podemos ver na casa de Sebastiana de Souza Queiroz, a escadaria era muitas vezes pensada como um elemento cenográfico, através do qual, de maneira elegante e garbosa, os donos da casa se apresentavam aos seus convivas. No topo do descanso, suas figuras e roupas eram colocadas em um pedestal sob a contraluz de um delicado vitral, para serem admiradas e reverenciadas. Um rito de imponência e pompa seguramente repetido à exaustão pelos aristocratas do Setecentos ${ }^{57}$ (FIG. 54-55).

Paralelamente ao esforço de nobilitação, chegavam à Avenida outras elites, cujas estratégias e interesses percorriam caminhos diversos. Tratava-se de locais e estrangeiros que construíram casas de grande porte, porém com contornos menos palacianos. Em sentido contrário, em algumas dessas obras predominaram as referências a tipologias civis, com grande destaque aos elementos de chalé, geralmente compostos por um telhado de duas águas com pináculos na cumeeira e contornado por lambrequins.

A opção por esses elementos, entre os locais, para além do acolhimento e do conforto oferecidos por essa cobertura, tipicamente ligada ao imaginário pitoresco, pode ter encontrado fundamento também em suas potências simbólicas ${ }^{58}$. Desde meados do século XIX, tais elementos foram incorporados na sociedade paulistana como um sinal de

\footnotetext{
${ }^{56}$ MALTA, 2011; CARVALHO, 2008; SILVA, FERREIRA et al., 2015 e HOMEM, 1996.

${ }^{57}$ Infelizmente não foi possível tirar uma foto da escadaria da residência de Sebastiana antes da finalização deste trabalho, sendo assim, esta pode ser observada apenas na planta de sua residência (FIG. 41). Contudo, colocamos outras duas fotos que remetem a situação semelhante, a escadaria da Vila Penteado e da Residência de Stella e Martinho da Silva Prado, ambas na mesma região da de morada de Sebastiana (FIG. 54-55).

${ }^{58}$ De acordo com Eudes Campos: "John Ruskin, por exemplo - em sua conferência sobre o Domestic Revival (Edinburgo, 1853), na qual afirmava os valores dos edifícios vernáculos e do cottage -, asseverava que era a forma do telhado o que o distinguia das construções domésticas neoclássicas, que tanto desprezava, por tal forma ser não só pitoresca por si mesma, mas por exprimir a profunda necessidade humana de um abrigo. O cottage era essencialmente um telhado. Sua alma - sua essência e significado reduzia-se ao teto; era nisso que consistia o abrigo, era nisso que se diferenciava o cottage de uma simples fenda na rocha ou de um esconderijo entre as árvores. Era na espessa e impenetrável cobertura de palha do cottage que se concentravam o seu âmago e hospitalidade. E Ruskin convidava os ouvintes a reparar na diferença existente entre as expressões 'sob o meu teto' e 'entre paredes'”. CAMPOS, 2008, p.54.
} 
cosmopolitismo, associado ao modo de vida recatado e comedido do gentleman britânico ${ }^{59}$, ou ao espírito pragmático e empreendedor do yankee norte-americano ${ }^{60}$. O engenheiro Fernando de Albuquerque, por exemplo, apresentava em seu próprio cottage no Centro sua habilidade profissional, bem como sua identificação com os valores e virtudes dessa burguesia anglicana, ambos fruto de sua formação nos Estados Unidos ${ }^{61}$. Aparentemente, empenhava-se no mesmo sentido Aureliano Gusmão, proeminente político do Partido Republicano, que sustentava imponentes elementos de chalé em sua morada na Avenida Angélica, construção realizada pelo Escritório Técnico Ramos de Azevedo (FIG. 56-57).

Em meio à predominância dos nativos, também chegavam à Avenida estrangeiros enriquecidos. No bairro aristocrático, buscavam a ampliação de sua inserção nos circuitos locais, bem como o destaque de sua eminência das dificuldades e preconceitos de que padeciam seus congêneres menos afortunados. À semelhança do que Paulo Garcez observara para os imigrantes que erguiam suas moradas na Avenida Paulista, para alguns destes, notadamente os de origem teutônica, a menção ao chalé guardava outros significados. Distante do universo britânico, alemães como Henrique Fischer e Werner Rieckamnn apropriavam-se de seu vocabulário para remeter à sua própria pátria. Procuravam inserir-se no passeio das elites não através da assimilação, mas pela afirmação triunfante de sua própria identidade étnica ${ }^{62}$. Não à toa, para a edificação de suas moradas, contrataram um engenheiro-arquiteto suíço, Armando Reimann. Uma aproximação que pode ter sido motivada tanto pela vizinhança do gosto, como pela solidariedade da condição estrangeira.

O orgulho imigrante, amalgamado com a magnitude volumétrica, tornava as residências de Rieckmann e Fischer verdadeiros monumentos à laboriosa origem de suas riquezas ${ }^{63}$. Diferentemente do privilégio ostentado nos palacetes locais, procuravam expressar a boa

\footnotetext{
${ }^{59}$ O ideário ao redor do gentleman foi explorado por Carl Schorkse em SCHORSKE, Carl. Da cena pública ao espaço privado: a arquitetura como crítica cultural. In: SCHORSKE, Carl. Pensando com a História. São Paulo: Companhia das Letras, 2000, p.179-194.

${ }^{60} \mathrm{Um}$ tema ainda por ser estudado. Contudo, passamos por muitos indícios que sinalizam tal admiração pelos yankees desde finais do século XIX. Vide, por exemplo, os rasgados elogios feitos ao caráter arrojado e obstinado dos norte-americanos pela redação do Correio Paulistano na cobertura da inauguração dos bondes elétricos em São Paulo. Correio Paulistano, 8 mai. 1900.

${ }^{61}$ Com seu chalé, Albuquerque não exibia somente sua formação - cultura e profissional - estrangeira, mas também exibia o tipo de projeto que se especializara em sua passagem pelos Estados Unidos, e que era largamente cobiçado pelas elites locais à época. CAMPOS, 2008.

${ }^{62}$ MARINS, 2016.

${ }^{63}$ Ibidem.
} 
capacidade para os negócios - no caso deles, os sucessivos esforços empreendidos para obter notoriedade nas atividades de importação, atividade para a qual, de maneira singular, o anúncio da condição estrangeira poderia ser de grande préstimo, por sinalizar relações profundas no continente europeu, bem como o bom domínio do gosto dali proveniente (FIG. 58-59).

O brio dos imigrantes, contudo, não passava desapercebido pelos nacionais. Em 1915, através de singela nota, o engenheiro Celso Viana, responsável pela análise do projeto de uma residência de autoria de Reimann, no número 125 da Angélica, aponta que "o prédio é do tipo 'Chalet', para o qual os pés-direitos altos prejudicam a estética sem vantagens para a salubridade da habitação" ${ }^{64}$. Apesar do linguajar técnico, a censura era apartada de suas incumbências, uma vez que restrições estéticas eram aplicadas pela Prefeitura somente no Centro $^{65}$. Atitude que parece ressoar a ascendência das intolerâncias sociais e estéticas que emergiam contra o elemento estrangeiro naquela década. Ecos, no campo da arquitetura, das críticas aos estrangeirismos divulgadas primeiramente por Ricardo Severo ${ }^{66}$, e depois por Monteiro Lobato e Mario de Andrade ${ }^{67}$.

No esteio do ufanismo nacionalista, a linguagem neocolonial ganhava espaço no gosto das elites locais, aproveitando as feridas abertas pela lenta e dolorida decadência do Ecletismo cosmopolita, cada vez menos capaz de inspirar confiança após o esfacelamento da Europa na Primeira Guerra Mundial. Como nova estratégia nobilitante, adotavam o "estilo brasileiro" as famílias que pretendiam dizer-se "quatrocentonas", afirmando seu vínculo de longa data com a terra nacional através das emulações de símbolos coloniais. Nesse estilo, ergue casa para sua família, na Angélica com a Higienópolis - uma das mais nobres esquinas da cidade -, o médico Adolfo Schmidt Sarmento. Nascido em 1883, Schmidt graduou-se em 1906 na Faculdade de Medicina do Rio de Janeiro. Passando dificuldades financeiras à época,

\footnotetext{
${ }^{64}$ AHSP/SOP/OP1915_000.161 apud LODY, Jorge. Arquitetura e Cidade: obras particulares em São Paulo 1906-1915. Tese (Doutorado) - FAUUSP, São Paulo, 2015, p. 68.

${ }^{65}$ Cf. Código de Posturas do Município de São Paulo de 6 de outubro de 1886.

${ }^{66}$ SANTOS, Alessandra Xavier dos; SILVA, Andressa Amaral da; DANTAS, Wesley Nunes (org.). Ricardo Severo: "A Arte Tradicional no Brasil". [Originalmente publicado em Revista do Brasil, São Paulo, ano II, vol. 4, jan.-abr, 1917, p. 394-424. Texto com grafia atualizada]. 19\&20, Rio de Janeiro, v. VII, n. 1, jan./mar., 2012 e MELLO, Joana. Da arqueologia portuguesa à arquitetura brasileira. São Paulo: Annablume, 2007.

${ }^{67}$ MARINS, 2016, posição 1029-1102 (edição Kindle).
} 
trabalhara durante o curso para sustentar-se e, assim que formado, fora buscar emprego no interior de São Paulo. Firmando-se em Santa Cruz do Rio Pardo, angariou fundos para especializar-se em otorrinolaringologia em Berlim e Viena. De volta ao Brasil em 1912, ingressou como médico na Santa Casa de Misericórdia e como professor assistente na recém-fundada Faculdade de Medicina e Cirurgia de São Paulo.

Na década de 1920, já era livre-docente na Faculdade, ambiente no qual, além do ganho monetário, deve ter conquistado acesso a elevados círculos da sociedade ${ }^{68}$. Nesses tempos, o nacionalismo começava paulatinamente a amotinar as elites e Schmidt carregava em seu nome uma evidente ascendência alemã ${ }^{69}$. Pode ser que, com a construção de uma enorme residência neocolonial, ele procurasse ofuscá-la, ou apenas inserir-se, ao menos simbolicamente, no efervescente círculo cultural nativista ${ }^{70}$. Mesmo desconhecendo esses detalhes sobre a trajetória de Schmidt, podemos supor que a estratégia parece ter-lhe rendido boas amizades e, com elas, valorosas oportunidades. Ao menos é o que parece atestar a estreita amizade que mantinha com Antônio de Almeida Prado, responsável por discursar à beira de seu túmulo em 1939. Além de carregar o gene "quatrocentão", Prado foi um próspero administrador da era Vargas, ocupando durante o governo provisório os cargos de Diretor do Serviço Sanitário do Estado de São Paulo, Secretário da Educação e Saúde Pública do Estado, Diretor da Faculdade de Filosofia, Ciências e Letras da Universidade de São Paulo e vice-reitor da mesma instituição ${ }^{71}$. Uma amizade que, como tantas outras, certamente

\footnotetext{
${ }^{68} \mathrm{~A}$ data exata de construção da residência não foi encontrada, sendo delimitada apenas como década de 1920 na publicação de tombamento encontrada na Resolução n ${ }^{\circ}$ 22/2013 do Conpresp. A autoria do projeto é de Alexandre Ribeiro Marcondes Machado, que, além de engenheiro, ficou conhecido por seu alter ego ficcional, Juó Bananere.

${ }^{69}$ Apesar do autoritarismo nacionalista tomar conta do cenário político oficial brasileiro a partir da década de 1930, na década de 1920 já estavam sendo paulatinamente disseminados esses ideários xenófobos, como aponta Boris Fausto. Sendo assim, é possível que indivíduos de ascendência estrangeira começassem a preocupar-se em legitimar sua presença em solo nacional. FAUSTO, Boris. O pensamento nacionalista autoritário no Brasil. Rio de Janeiro: Jorge Zahar, 2001, p. 20-30. Boa referência dessa defesa dos estrangeiros por seu pertencimento nacional pode ser acompanhada no estudo de Ana Castro sobre o peculiar discurso nacional de Menotti del Picchia, ele mesmo um descendente de italianos, que era mais brando e aberto aos estrangeiros do que o estrito nativismo defendido por alguns de seus contemporâneos. Cf. CASTRO, 2008.

${ }^{70}$ Cf. AMARAL, Aracy. O modernismo brasileiro e o contexto cultural dos anos 20. Revista USP, São Paulo, n. 94, p.9-18, jun/ago 2012.

${ }^{71}$ Homenagem ao novo reitor da Universidade de São Paulo: Prof. Dr. Antonio de Almeida Prado. Revista de Medicina, nov/dez, 1946, p. 564-576. E breve biografia de Adolpho Schmidt Sarmiento
} 
encontrava firmeza no campo da intimidade e do afeto. Mas se tinha desdobramentos nos campos da profissão e da política, não é de se estranhar que as credenciais patrióticas de Schmidt fossem requisito básico à sua inserção nos prestigiados círculos de relações do amigo (FIG. 60).

Embora as expectativas das elites para o passeio fossem altas, como já vimos, não eram as únicas a povoarem a Angélica. Em vias como a Avenida Paulista e a Higienópolis, os agentes imobiliários convergiram, de fato, para um projeto de uma rua-exibição. Nessas, as largas dimensões laterais dos lotes permitiam a apreensão isolada de cada obra, sua mirada de diferentes ângulos, bem como davam maior liberdade à sua volumetria. O ritmo vagaroso e pausado entre as edificações tornava a expressão de cada uma mais potente, bem como sua localização mais distinta e particular (FIG. 61-62).

$\mathrm{Na}$ Angélica, padrão semelhante podia ser experienciado apenas em trechos específicos. Um de seus momentos mais pomposos era o quarteirão onde estava localizada a residência de Maria Angélica de Sousa Queiroz, entre a Baronesa de Itu e Alameda Barros, situada na esquina da segunda com a Avenida. Grande parte dos pedidos de obra para esse quarteirão tem início em meados da década de 1910, sendo provável que, até então, Maria Angélica ainda contasse com a enorme gleba como quintal de seu casarão. Grande parte dessa terra foi concedida a seus parentes, transformando a quadra em uma espécie de congregação de sua família. Ergueram palacetes ali seus filhos Bento Queiroz de Barros ${ }^{72}$ e Antonia Aguiar de Barros de Ulhoa Cintra ${ }^{73}$, bem como Anibal Paes de Barros, presumível relacionado de seu falecido marido Francisco de Aguiar de Barros ${ }^{74}$, e sua prima, Sebastiana de Sousa Queiroz. Alfredo Aguiar de Barros, igualmente descendente de Angélica, também possuía terreno na Avenida $^{75}$, apesar de não termos constatado sua morada na localidade. Contudo, Alfredo, assim como outra grande parte da parentela, residia nas proximidades, notadamente concentrados na Alameda Barros e na Rua São Vicente de Paula. O zelo de Maria Angélica com as redondezas de sua casa era patente. Tanto que, em 1914, ao empreender vinte e três

realizada pela Academia de Medicina de São Paulo. Disponível em: www. academiamedicinasaopaulo.org/biografias (último acesso em fevereiro de 2017).

${ }^{72}$ Correio Paulistano, 22 jul. 1914.

${ }^{73}$ Correio paulistano, 12 abr. 1922.

${ }^{74}$ Pedido de construção de residência na Av. Angélica, 29. Fundo de Obras Privadas do AHMSP, cxs. 1911.

${ }^{75}$ Correio paulistano, 9 mai. 1917. 
casas de tipo "operário”, decide por não fazê-lo em suas próprias terras, mas em grande gleba comprada no Bom Retiro ${ }^{76}$, reservando seus arredores para o projeto exclusivista que compartilhava com outros membros das elites.

Contudo, ao passo em que a matriarca se esforçava em preservar o aspecto nobre de sua morada, o proprietário das terras do outro lado da via, Domingos José Nogueira Jaguaribe, comercializava as terras de Santa Cecília tangentes à Avenida em lotes estreitos e com fundos reduzidos, mais propícios à construção de residências de porte mediano, geminadas ou com estreitos recuos laterais. A densidade de cada lado da rua era de gritante discordância. Igualmente patentes eram suas descontinuidades sequenciais, desarmonia visual que explicitava as forças multidirecionais que guiavam seu sinuoso rumo sociomaterial. Essas casas, que se intercalavam com os palacetes até a Rua Goiás, e que, no topo, por vezes eram erguidas em meio às vivendas dos trabalhadores, eram a morada dos abundantes setores médios que chegavam à Avenida, trazendo consigo outros interesses e expectativas para o cotidiano do estimado passeio das elites (FIG. 63).

${ }^{76}$ Pedido de construção de residência na Av. Angélica, 29. Fundo de Obras Privadas do AHMSP, cxs. 1914. 

O trampolim dos remediados 

Os medianos que se dirigiam à Angélica, apesar de situarem-se em um campo em posição inferior às elites, guardavam, em sua maioria, um habitus semelhante ao dos abastados. Passavam a vida sonhando com a ascensão e temendo a queda, eram fervorosos cultistas do trabalho, baluartes do casamento e convictos adoradores do conforto doméstico. Contudo, diferiam pela necessidade mais urgente de distinguir-se do campo que lhes era inferior e o anseio ardente de aceder ao campo que lhes estava acima, e também pela discrepância no acúmulo de capital cultural, clivagem que sustentava as poderosas fronteiras de distinção e segregação sustentadas pelas elites. Superá-las, portanto, exigia aprimorar o seu próprio habitus, tanto no âmbito de eidos, com o domínio de representações mais intelectualizadas e científicas do mundo, quanto na hexis, com o domínio do chamado "bom gosto" e de todas as técnicas de gestual e sociabilização. O indivíduo mediano ascendia economicamente à posição semelhante à das elites, contudo, seguia impossibilitado de penetrar nesse campo por conta de seus hábitos "vulgares", oriundos de seu habitus de classe média - é o caso clássico do noveau riche.

Enfim, eram indivíduos e famílias que possuíam renda suficiente para atender a um padrão de vida mediano, porém não desfrutavam dos amplos privilégios sociais e econômicos das elites. Contudo, sonhavam em um dia poder tê-los, e para tanto embrenhavam-se em processos miméticos, através dos quais procuravam atribuir-se vestes comportamentais e materiais mais ornadas, de maneira a aproximarem-se 
simbólica e concretamente das elites, bem como obter posição mais avantajada dentro de seu próprio campo.

Sua renda podia ter muitas procedências: pequenas propriedades rurais ou urbanas, baixos e medianos cargos políticos e administrativos, módicos negócios, ou ainda, o exercício de uma profissão liberal. Embora não fossem um grupo homogêneo, a incerteza era um traço marcante na vida de sua maioria. É certo que as elites também se inquietavam com as instabilidades da mobilidade social, mas, para o primeiro grupo, o equilíbrio era ainda mais tênue. Mais do que um fantasma ou uma ligeira queda nos padrões de conforto e na escala dos privilégios, a descensão para os remediados poderia significar uma drástica mudança no modo de vida. Por sua vez, o sucesso não raras vezes era capaz de revolucionar o seu dia a dia. Frente a esse incerto quadro de expectativas, alguns adotavam estratégias conservadoras, enquanto outros sonhavam com os saltos mais ousados, afrontando a sorte e o risco com maior ou menor sucesso ${ }^{1}$.

Chegam à Avenida sobretudo a partir de 1907, quando começam a proliferar os palacetes. Para além do conforto e do bem-estar, ali parecem ter enxergado um campo de oportunidade. A vantagem da circunstância, contudo, era aproveitada e apropriada de maneiras distintas, dependendo das estratégias adotadas por cada um em sua peculiar trajetória. Para os que se viam em círculos virtuosos e prósperos de ascensão, a proximidade com as elites poderia resultar na formação de novos laços. Além do mais, a localidade enobrecida era um aparato simbólico de grande eficácia na solidificação dos postos alcançados, bem como na formação de uma base para almejar sua ampliação.

$\mathrm{Na}$ esteira desse prestígio, também embarcavam os pequenos e médios proprietários, como vimos anteriormente. Apesar de alguns construírem apenas casas para negócio, não foram raros os que chegaram primeiramente com suas moradas e depois decidiram erguer em suas proximidades outras casas de aluguel. O endereço e a vizinhança eram atributos de valorização de suas terras, o que permitia grande rendimento na locação e tornava o rentismo um seguro caminho para a estabilização

${ }^{1}$ OLIVEIRA, 2005, p. 18. 
social. Para esses, mais do que uma via de prestígio, a Avenida era um negócio e seu enobrecimento imagético, um prestimoso benefício econômico.

Para os profissionais liberais que não possuíam renda para alugar um escritório no Centro, espaço primordial dos serviços e negócios da cidade, a morada na Avenida também era atraente. Primeiramente, sobretudo a partir da instalação do bonde elétrico, por seu acesso descomplicado à clientela que vinha de outros bairros. Em seguida, pela possibilidade de ter o escritório conjugado à residência sem grande prejuízo simbólico, afinal, a atmosfera enobrecida que circundava a Angélica também dizia respeito ao domínio da intelectualidade, do gosto e da técnica, valores facilmente vinculados à destreza e à competência laboral. No caso das profissionais mulheres, o avizinhamento permitia a conquista da clientela abastada feminina da região, para a qual, paradoxalmente, a praticidade e o conforto de receber atendimento diretamente nos arrabaldes era complementar ao bucólico ideal de vida cultuado pela alta sociedade.

Por fim, diante dos vultosos capitais sociais que acumulavam os habitantes dos palacetes, havia os que buscavam na Angélica a consolidação e fidelização de laços socioeconômicos. Essa estratégia parece ter sido mais frequente entre membros despossuídos das famílias abastadas que habitavam a via e suas proximidades, com destaque para os Sousa Queiróz, os Aguiar e os Pais de Barros. Muitos deles, como veremos, rodeavam em torno de Maria Angélica, o que parece ter ajudado parte de sua parentela a constituir morada e renda através de suas terras.

Apesar de frequentemente procurarem assimilar o modo de vida das elites, a aproximação dos remediados com a alta sociedade não era isenta de tensões. A começar pelo âmbito social: os que chegavam em plena ascensão poderiam ser vistos como ameaças às elites já estabelecidas, ainda mais para os grupos em situação menos acomodada. No âmbito simbólico, se compactuavam com o exibicionismo, a discrepante paisagem que ali soerguiam interferia drasticamente no suntuoso projeto do passeio. O ritmo pausado dos palacetes era invadido pelos curtos e repetitivos intervalos de suas casas, sem contar a monotonia repetitiva de seu vocábulo ornamental, que conflitava com o tom triunfante das obras únicas. Alguns, mais 
arrojados, tentavam artifícios para romper essas rígidas barreiras do gosto e da sofisticação em que se encastelavam as elites. Não só recorriam aos seus diletos profissionais, como os do Escritório de Ramos de Azevedo, como a eles encomendavam engenhosas fabricações, elaboradas para borrar e diluir as fronteiras formais e estéticas que imperavam entre as casas médias e os palacetes.

Essas barreiras não se impunham apenas no universo material, mas também nos gestos e hábitos cotidianos. Assim, não parece exagero imaginar que as distâncias culturais e econômicas que distinguiam as elites dos remediados proporcionassem a estes uma experiência singular do cotidiano da Avenida. Uma vivência que não encontramos em jornais, plantas ou mapas, mas que pode ser imaginada, ao menos como um ensaio, a partir da trajetória de Lola, uma moradora fictícia da Avenida Angélica, retratada por Maria José Dupré em seu romance Éramos Seis (1943)².

Perto da casa modesta que a protagonista compartilhava com seus dois filhos e o marido, um afoito assalariado, morava sua tia-avó em um palacete. Ao chegar no novo bairro, sua mãe insiste que visite a tia, não por afeto, mas porque a esta devia muitos favores. O embaraço proporcionado pelo contato com o ambiente da classe superior é marcante, desde o rito que precede a visita - a costura de vestidos e chapéus “apresentáveis" por Lola e suas irmãs - até o constrangimento das visitantes frente ao gosto peculiar do refresco de orchata, que a tia e suas confrades apreciavam alegremente 3 . Para Lola, o palacete era "um sonho das mil e uma noites", ao mesmo tempo em que lhe impunha "respeito e medo". Essa ambígua experiência era marcada pelas fronteiras do gosto, dos hábitos e dos costumes, que se impunham como um desafio para sua inserção naquele ambiente.

A percepção dessas barreiras se desenrola por todo o enredo, tendo seu ápice na festa de sua tia, à qual Lola comparece junto ao marido. Empenham suas economias no aluguel de roupas, chauffeur e carruagem. Ao saírem, a vizinhança se reune para vê-los partir, mas, ao chegarem à festa, surpreendem-se ao descobrir que a mera posse

\footnotetext{
2 DUPRÉ, Maria José. Éramos Seis. São Paulo: Ed. Ática, 1973, 8ª edição (original de 1943).

${ }^{3}$ DUPRÉ, 1973, P. $22-23$
} 
da materialidade não era suficiente, precisavam também perfomatizá-la ${ }^{4}$. O resultado não poderia ser mais desgraçado: Lola se estabana por diversas vezes com seu vestido, sente-se sufocada pelo espartilho, além de falhar em todas as tentativas de integração com os convivas. Seu marido, além de dores nos pés provocadas pelos sapatos novos, ao desconhecer a moderação alcóolica cultivada na alta sociedade, acaba por embriagar-se em excesso e provoca confusões com os convidados. Na saída, briga com o chaffeur, que lhe pedia um aumento da quantia acertada. Quando os ânimos começam a ferver, intervém o mordomo da tia, que paga a quantia que faltava. Para casa retornam de automóvel, mas em tom de desânimo e frustação ${ }^{5}$.

Viver entre as elites demandava a inculcação completa de um habitus que não era tão facilmente assimilado pelos que não o recebiam desde o berço ${ }^{6}$. A diferença estava patente nos gestos, nas roupas, nas casas e nos jardins. Não seria de se estranhar então, que muitos remediados, como Lola, ansiosos por inserir-se na alta sociedade, nutrissem em seu cotidiano a ambígua relação de medo e deslumbre diante da abastada vizinhança. Vejamos mais de perto algumas trajetórias que nos permitirão melhor compreender os encontros e desencontros de interesses, bem como as sinuosas estratégias dos irrequietos setores médios em sua fixação na Avenida.

Provindos de localizações menos enobrecidas e sem laços sanguíneos notáveis para constar em uma genealogia, buscavam incorporar à suas imagens pessoais os epítetos que os ricos conferiam ao endereço aristocrático. Nos jornais, como O Estado de São Paulo, Correio Paulistano e O Combate, vemos que a qualificação de indivíduos através do endereço residencial era uma prática extremamente frequente. Apareciam nas colunas sociais e notícias, e não raramente também nos anúncios de vendas e serviços,

\footnotetext{
${ }^{4}$ A ideia da necessidade de perfomatizar os objetos me foi sugerida pelas instigantes análises de HELLMAN, 2006.

${ }^{5}$ DUPRÉ, 1973, p. 33.

${ }^{6}$ Nesse sentido, interessantes reflexões foram feitas por Marize Malta e Vânia Carvalho, que apontam o ambiente doméstico das elites, em sua convivência sociomaterial, como um dos aparatos fundamentais de inculcação do gosto, do código de conduta dentro da alta sociedade e de uma determinada hexis. Para a formação do gosto através dos objetos e da decoração doméstica, Cf. MALTA, 2011, p. 35-64. Para uma penetrante análise sobre a constituição da hexis ambicionada pela alta sociedade e de sua importância nos jogos sociais, cf. CARVALHO, 2008, p.181-218. Por fim, para uma análise sobre a importância do gosto como elemento fundamental nas distinções entre as classes sociais e suas utilizações estratégicas nos jogos da vida cotidiana, cf. BOURDIEU, 2007 e BOURDIEU, 1983.
} 
onde figuravam lado a lado com o endereço profissional. Para além de suas finalidades práticas, com importância análoga ao sobrenome ou à ocupação, o endereço parecia funcionar como um importante marcador social.

Se era relevante no meio escrito, não seria estranho que também o fosse no uso cotidiano. Sua potência pode ser vislumbrada, outra vez, em situação vivida pela protagonista de Éramos Seis. No começo do enredo, Lola muda-se do Bom Retiro para a Avenida Angélica, mesmo que tal mudança lhe custe o dobro do aluguel e uma vida inteira dedicada a "pagar a casa". Ao relatar a novidade a suas irmãs, estas, sem conhecer as módicas proporções de seu lar, respondem: "Então agora é só no palacete, hein? Muito bem. Vocês estão progredindo; estamos ansiosas por conhecer a nova residência, ainda mais nesse bairro tão elegante"7.

$\mathrm{Na}$ Avenida, muitos repetiram o percurso de Lola. Não seria de se estranhar que também tenham vivido situações análogas, travadas na intimidade familiar, entre amigos e, sobretudo, nos ambientes comerciais e profissionais. Esses colóquios tinham grande potência simbólica, pois sinalizavam a ascensão e, consequentemente, a habilidade em sua ocupação - boa impressão que, se não garantia, decerto cooperava em muito para a realização de futuros ganhos econômicos.

Nessas ocasiões, a representação da via revelava novamente seu poder. Mesmo que se tratasse de moradores de sobrados geminados, o retrato pujante do endereço se sobrepunha no imaginário de seus interlocutores. $\mathrm{O}$ crer para ver não era exclusivo às ardilosas mentes da Câmara, mas sim um artifício corrente, largamente difundido entre os remediados que buscavam vestes mais ornamentadas. Uma experiência que ampliava seu ancoramento em proporção igual ao desnorteante crescimento espacial e social da cidade. Rostos e sobrenomes começavam a escapar do domínio total, assim como o vasto desdobramento territorial. Tornava-se impossível a um indivíduo conhecer todas as ruas da cidade, muito menos ter em mente as minúcias de sua paisagem. Daí a ampla capacidade de difusão das estereotipadas representações de bairros e localidades, que procuravam fixar, para as mais distintas finalidades, mapas

${ }^{7}$ DUPRÉ, 1973, p. 17. 
mentais que hierarquizavam simbolicamente os espaços da cidade ${ }^{8}$. Um universo aparentemente completo na imagem, mas repleto de brechas na concretude. Interstícios ardilosamente aproveitados pelos remediados, que encontravam boa oportunidade para vestir-se com roupas mais vistosas e ornamentadas do que as concretamente vivenciadas.

Vejamos a interessante trajetória do coronel Augusto Piedade. Filho do coronel Emygidio Piedade, que fora deputado da Província de São Paulo, iniciou sua vida adulta na cidade de Faxina, onde realizou o serviço militar e ocupou o ofício de tabelião de notas da Câmara Municipal, que era presidida por seu irmão Accacio. Em 1909, decide ir a São Paulo, abandonando a segurança de seu cargo vitalício, bem como a privilegiada posição da família no município. Uma manobra ousada, ainda mais dada sua frágil condição salutar, que já lhe havia imposto diversos afastamentos de seu ofício em Faxina para refúgios de bom ar e reclusão ${ }^{9}$ - condições antagônicas às que encontraria na capital. Chegando à cidade, filia-se ao escritório de advocacia de seus parentes José e Alencar Piedade, localizado no Centro, à rua Álvares Penteado, n. $2^{10}$. Os dois já possuíam inserção na cidade, sendo o primeiro, irmão de Augusto, comandante superior da Guarda Nacional e o outro, seu primo, alferes da mesma organização ${ }^{11}$. O escritório familiar tem curta duração e, já no ano seguinte, Augusto comunica no Correio Paulistano às "exímias famílias de suas relações e, em geral, aos seus amigos” sua mudança da rua Amaral Gurgel, 74, para a Avenida Angélica, 382 ${ }^{12}$. Nesse mesmo ano, seu irmão Accacio, até então presidente da Câmara Municipal de Faxina, elege-se deputado estadual, mas seu sucesso político não parece repercutir na prosperidade material de Augusto $^{13}$. A residência que compra na Angélica era de módicas proporções, como se pode averiguar

\footnotetext{
${ }^{8}$ Para uma interessante reflexão sobre a potência simbólica do endereço no meio urbano, porém com enfoque na atualidade, Cf. MELLO, Marco Antonio da Silva; SIMÕES, Soraya Silveira. "Onde você mora?”: propósitos e implicações do endereço. In: Duarte, Cristiane Rose; VILLANOVA, Roselyne de (org.). Novos olhares sobre o lugar. Rio de Janeiro: Ed. Contracapa/FAPERJ, 2013, pp. 65-81.

${ }^{9}$ Como veremos adiante na trajetória de Piedade, nas ocasiões em que foi acometido por severas crises de sua condição, ele se mudou para espaços campestres ou, ao menos, pouco urbanizados. A busca por "bons ares" era uma panaceia da medicina da época.

${ }^{10}$ O Commercio de São Paulo, Indicador, 29 mar. 1909.

${ }^{11}$ Correio Paulistano, 1 abr. 1910.

${ }^{12}$ Correio Paulistano, 4 abr. 1910.

${ }^{13}$ Correio Paulistano, 1 abr. 1910.
} 
em sua planta. Uma casa de quatro cômodos, sendo o dos fundos bastante exíguo, mais a cozinha. Abrigo para o dia a dia de conforto bastante restrito, se considerarmos que era compartilhado com suas duas filhas (FIG. 64).

O anúncio da mudança, como deixa patente a ordem de sua chamada, destinava-se principalmente à praça da cidade, na qual o Coronel tentava inserir-se com tenacidade. A mudança para um endereço enobrecido era um primeiro passo. Valendo de seu posto privilegiado de chefe do Partido Republicano de Faxina, que lhe garantia boas relações com seu veículo oficial na mídia, Augusto dá início a uma longa campanha de anúncios nos indicadores do Correio $^{14}$. Agora, propagandeava a abertura de um novo escritório de advocacia, dessa vez de sua exclusiva responsabilidade, situado na casa geminada à de sua nova residência ${ }^{15}$. No extenso anúncio, que correra o ano inteiro, além de salientar sua prestatividade - "atendo a chamados a qualquer hora para serviço na polícia” - e flexível remuneração - propagandeando seus "honorários módicos" -, o coronel lista à exaustão as suas competências jurídicas, um empenho que seus colegas de página, provavelmente com clientela já consolidada, não se prestavam mais ${ }^{16}$. Parecia comunicar-se com uma clientela em semelhante condição remediada, mais ou menos afortunada, para os quais, certamente, seu endereço enobrecido surtia boa impressão (FIG. 65).

Nos anos seguintes, ampliará seus esforços formando parcerias com outros advogados e juristas da praça paulistana. Principia em 1910, com uma breve sociedade com o também recém-chegado José de Malta Cardim, que não dura mais do que alguns meses $^{17}$. Em 1911, forma empresa com Antonio Augusto Rodrigues de Moraes, juiz aposentado de $\mathrm{Ubatuba}^{18}$. De princípio, a dupla firma escritório de advocacia forense e comercial, situado em um sobrado na Travessa da Sé, localização de grande prestígio na cidade. Além do auxílio jurídico, no escritório vendiam títulos da Rural Edificadora, empresa à qual Augusto havia recentemente se associado, provavelmente por intermédio

\footnotetext{
14 Boa relação explicitada, dentre outros fatos, pelas congratulações que todos os anos os redatores davam aos membros da família Piedade em seus respectivos aniversários. Cf., por exemplo, as felicitações à sua filha Augusta em Correio Paulistano, Crônica Social, 15 jun. 1910 e Correio Paulistano, Crônica Social, 15 jun. 1912.

${ }^{15} \mathrm{O}$ Escritório ficava no número 380 da Avenida Angélica.

${ }^{16}$ Correio Paulistano, 1 jul. 1910.

17 Até 1907 era advogado da Santa Casa de Misericórdia de Avaré, e antes era advogado em Itaporanga. Cf. respectivamente Correio Paulistano, 30 jan. 1907 e Correio Paulistano, 1 jan. 1903.

${ }^{18}$ Correio Paulistano, 28 dez. 1905.
} 
de seus contatos no Exército, uma vez que o diretor da mesma identifica-se como "General Glycério"19. No final do ano, a empreitada já dava os primeiros sinais de insucesso, forçando o retorno do escritório ao imóvel da Angélica, provavelmente uma medida de redução de despesas. O celebrado endereço de anos antes agora parece não agradar tanto aos advogados, uma vez que a saída do prestigioso Triângulo escancarava ao público suas desventuras iniciais ${ }^{20}$. O embaraço é tamanho que, procurando mitigar os danos simbólicos da manobra, acrescentam ao anúncio do jornal que o novo logradouro era apenas provisório. Ocasião que nos concede uma importante lição sobre o funcionamento figurativo dos endereços: os significados que mediatizavam não eram absolutos, mas circunstanciais. Assim, a exibição de um mesmo endereço poderia alternar, na curta trajetória de um mesmo indivíduo, do brio orgulhoso ao acanhado desassossego (FIG. 66).

$\mathrm{O}$ que se pretendia passageiro parece ter fixado permanência, sendo que até meados de 1912, quando o anúncio segue nas páginas do Correio, os advogados continuavam sediados na Angélica ${ }^{21}$. Nesse mesmo ano, devido a seu aparente malogro, o escritório é fechado e Augusto é acusado na praça de devedor, o que o leva a uma fervorosa irrupção defensiva no jornal ${ }^{22}$. Sob o motivo de tratar de sua irremediável enfermidade, Augusto abandona a cidade e retorna à sua urbe natal ${ }^{23}$. O imóvel onde funcionava o escritório é colocado à venda, sob responsabilidade de suas duas filhas, Augusta e Francisca, moradoras da mesma Avenida, nas proximidades da Paulista ${ }^{24}$. Anos após sua primeira tentativa frustrada, Augusto retorna à capital em 1915, com escritório na Rua D. Veridiana, depois transferido para um conjunto na Rua Benjamin Constant. Novamente tocado pelo azar da enfermidade, ou dos negócios, parte outra vez em 1919, dessa vez para instalar morada definitiva em Petrópolis ${ }^{25}$.

\footnotetext{
${ }^{19}$ Correio Paulistano, 27 mai. 1911.

${ }^{20}$ Para a configuração do Centro como paço primordial dos negócios, cf. BARBUY, 2006 e CAMPOS NETO, 2000.

${ }^{21}$ Cf. Correio Paulistano, 8 mai. 1912.

${ }^{22}$ Cf. Correio Paulistano, 4 jul. 1912.

${ }^{23}$ Correio Paulistano, 25 ago. 1913.

${ }^{24}$ As irmãs habitavam o imóvel de número 461 da Avenida.

${ }^{25}$ Correio Paulistano, 4 nov. 1919.
} 
O comprador da casa do coronel Piedade foi Augusto Machado Schmidt, sobre o qual pouco encontramos nos jornais locais. Ausência, contudo, significativa, denotando que não possuía laços estreitos com as elites locais, caso contrário teria sido identificado nas cotidianas listas de cumprimentos e participantes de eventos sociais e religiosos, como festas, núpcias, enterros e recepções. Se exercia atividade comercial, seu público tampouco estava situado entre a comunidade leitora desses jornais, pois ali não fazia anúncio. Por seu nome, pudemos apenas aferir que fazia parte de segunda ou terceira geração de imigrantes, uma vez que era composto pela mistura de apelido local e alemão.

Contudo, pela reforma que executa na antiga residência de Piedade, vê-se que Augusto possuía razoável quantidade de capital. Transforma a casa de padrão simples, na qual a circulação se dava por dentro dos compartimentos, em uma residência mediana, com circulação delimitada; áreas de visita, família e serviço bem definidas; porão elevado e habitável; e cômodos ampliados. No primeiro momento, pode ser que a casa tenha sido utilizada para residência própria, porém, na década de 1920, quando as listas de imposto predial passam a figurar nas páginas d'O Correio, a residência não se encontra mais em sua posse ${ }^{26}$. Ao que parece, Augusto construiu no mesmo terreno uma outra casa para sua morada, rendendo a antiga um bom negócio que lhe permitiu adquirir outros dois imóveis na Vila Mariana ${ }^{27}$ (FIG. 64).

Anos antes, a venda do antigo escritório de Piedade para Schmidt parece ter dado impulso à ambiciosa carreira de suas filhas. Augusta e Francisca também procuraram sorte profissional na Avenida, porém valendo-se mais de seus aspectos práticos do que simbólicos. Distante da vida doméstica a que os mais abastados relegavam suas filhas durante a espera pelo matrimônio, as irmãs Piedade tiveram uma trajetória de grande autonomia. Chegam a São Paulo antes do pai, para estudarem no Ginásio Macedo Soares. Morando junto à mãe no topo da Angélica, nas proximidades do Hospital de Isolamento, formam-se com distinção no quinto ano em 1909. Nesse ano, morre a progenitora, indo

\footnotetext{
${ }^{26}$ Com a correção do emplacamento, a antiga remete ao número 262 da Avenida e a de sua morada, ao 263. Para as mudanças de numeração da Avenida, consultamos o Livro de Emplacamentos de Ruas pertencente ao AHMSP. Para lista de impostos prediais cobrados em 1928, cf. Correio Paulistano, 9 mai. 1928.

${ }^{27}$ Correio Paulistano, 6 jun. 1927 e Correio Paulistano, 7 jun. 1927.
} 
as duas para a casa vizinha, comprada pelo coronel, deixando a da mãe para um aluguel temporário ${ }^{28}$.

Após formadas, iniciam diretamente o curso de bacharel em ciências e letras, que concluem em $1911^{29}$. No ano seguinte, ingressam no recém-criado curso de medicina da Universidade de São Paulo e no curso de odontologia da Escola de Farmácia, que finalizam no mesmo ciclo $^{30}$. Em busca de sustento, começam rapidamente a buscar emprego, acumulando experiência como auxiliares de cirurgia dentária no Dispensário da Luz, no Internato Dr. Macedo Soares e no Asilo dos Expostos da Santa Casa. Dois anos depois, voltam sozinhas a morar na casa que era da mãe. Ali, decidem abrir um consultório odontológico. A casa fora construída para negócio por Alfredo Pacheco em 1903. De fachada simples, era ainda mais modesta que a do pai: possuía apenas três cômodos mais a cozinha, acoplada a um minúsculo banheiro. A singeleza da casa, contudo, não as impedia de manterem estreito contato com a alta sociedade do bairro.

Gozando da boa reputação que seu pai mantinha dentro do Correio, a inauguração do gabinete dentário foi noticiada em ampla nota no quarto dia de janeiro daquele ano ${ }^{31}$. A cerimônia principiou com uma benção do vigário da Bela Vista, tendo como padrinhos Álvaro Guimarães, diretor da Cia. Intermediária de Café de Santos ${ }^{32}$, e sua esposa Maria Prado Guimarães. Ao evento, compareceram muitas “senhoritas, senhoras e cavalheiros”, aos quais foram apresentados o "bom gosto estético e artístico das instalações e materiais", bem como exibidos o funcionamento de toda a aparelhagem cirúrgica e clínica. Em seguida, ao som da música tocada ao piano, foi posta a mesa de licores e doces, seguindo a palestra entre os convidados até o fim da $\operatorname{tarde}^{33}$ (FIG. 67).

Como o pai, as irmãs eram ambiciosas. Apostavam seus estreitos recursos na compra do maquinário, sem falar do dispendioso custo de sediar uma longa recepção, à maneira da alta sociedade. Mas dessa custosa propaganda, esperavam retorno, afinal, era

\footnotetext{
${ }^{28}$ Correio Paulistano, 31 dez. 1909.

${ }^{29}$ Correio Paulistano, 28 dez. 1911.

${ }^{30}$ Correio Paulistano, 15 jun. 1912.

${ }^{31}$ Correio Paulistano, 4 jan. 1913.

${ }^{32}$ Impressões do Brazil no século Vinte e CP, p. 713.

${ }^{33}$ Correio paulistano, "Gabinete Dentário”, 4 jan. 1913.
} 
justamente as senhoras da abastada sociedade que miravam como clientela ${ }^{34}$. Há de se notar que para tal finalidade a localização escolhida possuía especial atrativo. Como vimos, a corrente divisão de papéis de gênero dos abastados resultava também em uma demarcação espacial, circunscrevendo a vida feminina ao espaço doméstico. Ali, deveriam ser despendidas a maior parte de suas energias, direcionadas ao cuidado dos filhos, às recepções, à manutenção do lar e ao conforto marital. Confinamento que também servia ao controle de sua sexualidade, evitando encontros desregrados com homens desconhecidos ou indesejados pela parentela. Nessas circunstancias, não é difícil perceber o prestimoso benefício apresentado pelas doutoras: elas não só garantiam a convivência exclusiva com o sexo feminino, como também evitavam demora nas imprevisíveis ruas do Centro $^{35}$ (FIG. 68).

Diferentemente do pai, o destino imediato das doutoras não é facilmente mensurável. Os anúncios do consultório cessam seis meses depois da abertura, período que, contudo, seria muito curto para marcar um insucesso resoluto. Afinal, fora grande $o$ investimento ${ }^{36}$. Além do mais, as finanças pareciam equilibradas, tendo em vista que, paralelamente ao consultório, ocupavam-se com a venda de dois terrenos de pequena frente na Rua Minas Gerais ${ }^{37}$. No longo prazo, contudo, o fardo feminino lhes bate à porta. Em 1920, Augusta logra casamento com o banqueiro Antonio Simões de Carvalho. Ascensão próspera, mas que cobrava seu preço: o definitivo afastamento da vida profissional $^{38}$. De Francisca, pouco sabemos. Sua trajetória profissional pode ter prosseguido, apesar de não ter sido noticiada. Casamento dificilmente ocorrera, pois certamente teria sido prezado pelo diário que todo ano se preocupava em noticiar a ordinária festividade de seu aniversário. Pressão pelo seu matrimônio, contudo, não deve

\footnotetext{
34 Interessante notar que, por serem mulheres, provavelmente dificilmente conseguiriam clientela masculina, afinal, as capacidades femininas para o trabalho ainda eram extremamente subestimadas à época. Sendo assim, a escolha pela clientela exclusivamente feminina também obedecia a limitações de sua singular posição social de profissionais mulheres, e não somente à perspicaz percepção de uma boa oportunidade.

${ }^{35}$ Cf. capítulos primeiro e terceiro deste trabalho.

${ }^{36}$ Tanto com a grande quantidade de material e maquinário necessários para montar o gabinete, quanto com a instalação de uma linha telefônica no local.

${ }^{37}$ Correio Paulistano, 9 jun. 1913.

${ }^{38}$ Correio Paulistano, 22 jun. 1920.
} 
ter faltado. Talvez uma explicação para, três anos após o festejo da irmã, ela ter sido admitida à profissão de fé na Ordem Terceira do Carmo ${ }^{39}$.

As multidirecionais trajetórias da família Piedade nos permitem entrever as ambíguas relações mantidas pelos profissionais liberais e as elites na Avenida. O confronto estético e simbólico era patente: além de ocuparem casas que violavam o plano visual do passeio, desvirtuavam também o imaginário aristocrático, apropriando-se de um local valorado por sua exclusividade residencial como endereço enobrecido para o trabalho. Contudo, descobriam brechas que também vinham a ser convenientes às elites, como no caso do singular serviço oferecido pelas doutoras. Sutis instâncias de oportunidade, que talvez também tenham sido aproveitadas por outros argutos empreendedores da região. Ambivalentes relações, sinais da porosa matéria de que eram feitas algumas fronteiras da cidade, mostrando que, intercaladas às dissonâncias, os variados interesses da Avenida também encontravam afinação e confluência.

A essa disparatada sinfonia, também agregavam suas vontades os membros menos afortunados das distintas famílias que habitavam a Avenida. Para alguns, fortalecer os laços com a parentela era um meio para abrir caminhos de elevação, para outros, um dos últimos recursos para evitar a completa decadência. Este parece ter sido o caso de Cecília Aguiar, que muda-se para lá em 1908. Cecília era viúva de Constantino Aguiar, provável parente de um ramo pouco afortunado do clã de Francisco Aguiar de Barros, tendo em vista que não tivera seu nome consagrado na genealogia escrita por Luiz Gonzaga da Silva Leme $(1905)^{40}$. Na década de 1880, Constantino possuía uma loja de importações, localizada na Rua da Imperatriz, com o sugestivo nome "Ao Novo Mundo"41. Contudo, em meados da década seguinte, seu nome e loja desaparecem dos jornais e almanaques da cidade, indicando seu precoce falecimento. Para uma mulher de média idade, sem profissão e sem grandes fontes de renda, as possibilidades de sobrevivência na cidade

\footnotetext{
${ }^{39}$ Infelizmente não conseguimos precisar o significado exato desse rito. Contudo, de acordo com o que pesquisamos, especulamos que fosse uma afirmação pública de seus compromissos com a Igreja Católica. É no mínimo intrigante constatar que tal evento ocorrera precisamente três anos após o casamento de sua irmã. Cf. Correio Paulistano, 22 jun. 1923.

${ }^{40}$ Contudo, a circulação de Cecília pela alta sociedade é indubitável, pois não raras vezes ela figura em reuniões festivas e eventos sociais associada com os Penteado e com a família de Ruy Barbosa. Conferir, por exemplo, Correio Paulistano, 16 jul. 1908 e Correio Paulistano, 30 dez. 1909.

${ }^{41}$ Almanach da Provincia de São Paulo, 1887.
} 
eram restritas. Muitas chegavam ao extremo de recorrer ao mais desesperado meio de sustento: a mendicância, que pelas senhoras mais remediadas, ao invés das ruas, era exercida nas páginas de jornais como O Correio Paulistano. Cecília, por sorte de seu casamento, pôde recorrer à parentela do marido. Com a ajuda de Maria Angélica, se estabelece nas antigas terras de sua Chácara das Palmeiras. Ergue sua singela casa justamente onde a matriarca evitara a construção de imóveis para negócio. No caso da parente, o infortúnio estético não parece ser um incômodo, pois a ela também concede espaço para a construção de duas casas de aluguel para garantir o seu sustento ${ }^{42}$ (FIG. 69).

A materialidade da residência de Cecília exprimia sua peculiar posição social. Tratava-se de uma construção alinhada à via, com frente estreita e recuo mínimo em apenas um dos lados. O outro, no limite do terreno, provavelmente fora ladeado pelas residências de aluguel, relegadas a profissionais menos dispendiosos, pois para sua casa Cecília contratara o Escritório Técnico Ramos de Azevedo. Através da engenhosidade compositiva de um renomado construtor, procurava amenizar a discrepância de sua reduzida volumetria com a vizinhança apalacetada, bem como dar à casa uma identidade própria, distinguindo-a das tipologias padronizadas comumente empregadas pelos remediados (FIG. 70-71).

O maior empenho, naturalmente, foi empregado na fachada. Comecemos pela elevação. Observemos que o frontispício foi dividido em três partes exatas: a primeira, ocupada pelo gradil; a segunda, pelo primeiro bloco, colocado ligeiramente mais à frente; e a terceira, pelo outro bloco, mais à direita. Dessa maneira, o eixo médio do bloco central pôde coincidir exatamente com o eixo central do lote, de maneira a conformar uma certa estabilidade monumental à composição. Pela planta, podemos ver que essa divisão foi mantida somente para a fachada, sendo extravasada pelos cômodos mais ao fundo, que seguem a linha do recuo mínimo da lateral. Essa quebra não só era útil para o melhor aproveitamento do terreno, mas também fundamental para a fachada, pois ocupava o lado esquerdo, evitando o desequilíbrio excessivo de tê-lo completamente vazio. Da mesma forma, esse volume aparente não poderia ter a fachada lisa, pois ficaria em

\footnotetext{
${ }^{42} \mathrm{Na}$ lista de impostos prediais e de esgoto de 1927, vemos que Cecília possuía outras duas casas vizinhas à sua na Avenida Angélica. Cf. Correio Paulistano,6 jun. 1927 e Correio Paulistano, 7 jun. 1927.
} 
desbalanço com as sequências de janelas. Para tanto foi colocado um longilíneo arco em baixo relevo, que na elevação, à primeira vista, parece ser a porta de entrada.

A proeminência do bloco central, que garantia a grandiloquência da composição, foi ainda enfatizada pela adição de elementos verticais e horizontais, lembrando o tratamento dado ao eixo central nas composições neoclássicas. Na horizontal, há a interrupção da cornija, que forma uma espécie de frontão recurvado, estabilizado por dois elementos: o relevo quadrado com um círculo dentro, que pontua seu centro; e a fita com dois retângulos e um quadrado centralizado, colocada abaixo. Na vertical, o bloco central foi dotado com um coroamento, realizado pela platibanda em tamanho dobrado, porém com um harmonioso arremate, conformado pela transição de um retângulo maior para um menor, com frisos paralelos e ladeados por volutas. Por fim, o portão, com um elegante desenho recurvado, foi amparado por duas pilastras com pináculos, também obedecendo a uma rigorosa simetria axial.

No espaço interno, a despeito das pequenas áreas íntimas, a casa de Cecília possuía uma ampla área social, fundamental para as recepções e ritos necessários para estreitar os laços que cooperavam para sua sobrevivência. Nessas ocasiões, se a fachada não fosse suficientemente convincente, a assinatura do escritório de maior fama entre as elites paulistanas deveria cooperar em muito para o enobrecimento de sua proprietária. Em sua casa, embora não ostentasse a riqueza dos mais abastados, Cecília sustentava o domínio do capital cultural das elites. Esse controle, arduamente desejado pelos setores médios, já era suficiente para diferir-se da maioria deles. Em seu interior, diferentemente do de muitas outras casas da Avenida, certamente não veríamos a disseminação do que Thorstein Veblen chamou de consumo conspícuo. Trata-se da prática de obter objetos dos quais se ignora a utilidade, tendo apenas como finalidade o intuito de manifestar publicamente seu poder, riqueza e prestígio. Apesar da ideia ser aplicável também às elites, Veblen, quando a concebeu, tratava sobre os setores médios abastados, os noveaux riches, em fins do século $\mathrm{XIX}^{43}$. Isso porque, mesmo nos hábitos de consumo e representação, a diferença nos habitus era discrepante: enquanto as elites consumiam

\footnotetext{
${ }^{43}$ VEBLEN, Thorstein. A Teoria da Classe Ociosa: um estudo econômico das instituições. São Paulo: Ática, 1974.
} 
com requinte e exibiam-se com moderação e discernimento, os noveaux riches consumiam e exibiam-se de maneira vulgar e "deselegante".

Manobras autorais e materiais como a de Cecília foram recorrentes entre os remediados da Avenida. De fato, a maioria das residências de aluguel eram construídas em conjuntos geminados ou em série, a exemplo das nove casas de Antônio Ferreira da Rosa, ou dos sobrados de autoria e propriedade não identificados e até hoje existentes, retratados nos registros feitos por Gustavo Neves da Rocha na década de $1970^{44}$ (FIG.73). Para alguns, habitar uma dessas residências seriadas certamente já era motivo de orgulho. Contudo, para os mais abastados, ambiciosos e afoitos, a distinção desse outro grupo era fundamental.

Para tanto, como já observado por Carlos Lemos, alguns contratavam construtores para, à maneira da alta sociedade, transformar suas fachadas em um discurso singular e pessoal, colocando a architecture parlante a serviço de sua ascensão simbólica ${ }^{45}$. Outros apelavam para estratégias ainda mais ousadas. A dupla de casas geminadas, de posse e encomenda não identificadas, construídas em 1910 pelo escritório de Ramos de Azevedo constitui bom exemplo. Apesar de serem duas residências, na composição arquitetônica há poucos elementos que permitem sua distinção. Diferentemente da dupla de residências retratada por Neves da Rocha, na qual a composição espelhada explicitava o processo de geminação, nesta, ambas parecem compor uma grande mansão. Partido também adotado na composição das quatro residências com mansarda, também fotografadas recentemente pelo arquiteto, embora de maneira menos faustosa (FIG. 72).

Nas casas desenhadas pelo escritório de Ramos, a composição geral remete à elegância de um hotel privé setecentista: simetria axial, com escadaria e pórtico centralizados marcando a entrada, sinalização acentuada ainda pelo pequeno painel de arabescos em azulejo posicionado entre as duas biforas superiores. A presença de duas portas, além de ser estranha à composição, também evidenciaria a geminação. Para amortizar esse efeito, o construtor parece ter-se valido de um truque, evidente na elevação: posicionou duas janelas, que iluminam a escadaria, entre as duas portas, com tamanho e formato semelhante às entradas. Dessa maneira, a visão do expectador era

\footnotetext{
${ }^{44}$ As fotos da Avenida Angélica tiradas por Gustavo Neves da Rocha estão arquivadas no Acervo da FAU-USP.

${ }^{45}$ LEMOS, 1986.
} 
embaralhada, afastando-o da comparação dessa residência com outras composições geminadas conhecidas. Sensação ainda ampliada pela sombra do baixo telheiro do pórtico central, como podemos observar na foto tirada por Neves da Rocha (FIG. 74-77).

Contudo, o olhar atento revela assimetrias peculiares. Na esquerda da elevação, notase uma rótula no primeiro dormitório, bem como uma pequena arcada na sala de jantar, ambos ausentes no lado oposto. Da mesma forma, na planta notam-se cômodos mais amplos na área de serviços da residência da esquerda, bem como em disposição distinta de sua gêmea. Essa assimetria parece remeter a uma peculiaridade da encomenda de seu(s) proprietários(s). Podemos especular dois cenários. Um no qual a encomenda foi realizada por dois agentes distintos, porém bastante próximos, possivelmente aparentados, que fizeram ambos requisições de customização diretamente aos arquitetos. Outro, mais plausível por ter sido mais comum à época, no qual a residência da direita era para a morada do proprietário e a da esquerda, para aluguel. Dessa maneira explica-se seu menor tamanho, bem como a ausência de outros elementos, que aproximavam seu espaço de outros disponíveis no mercado de locação da cidade.

A rótula, por exemplo, tratava-se de um elemento polêmico à altura, portanto, pouco adequado para um imóvel de negócio. Como já apontado por Paulo Garcez, era considerada por muitos como um símbolo do "atraso", uma mácula do período colonial para as elites que procuravam assemelhar sua cidade às capitais europeias. Por outro lado, sua presença nessa residência mostra que, para outros, bem como demonstra o mesmo autor para os últimos anos do Império, esse elemento arquitetônico ainda guardava importantes funções simbólicas e até mesmo utilitárias, mesmo antes da difusão da estética neocolonial, que tem seu marco inicial apenas em $1914^{46}$. Para o dormitório, a rótula propiciava um confortável controle da iluminação e da ventilação. Na fachada, ela sinalizava uma relação de seu proprietário com as "raízes" da terra - como vimos, uma estratégia de enobrecimento corrente à época -, mensagem que, se foi menos comum nas fachadas residenciais até a difusão do neocolonial, era bastante corrente nos mobiliários nos interiores de classe média e elite, onde antigos baús dividiam espaço com louças, lustres e mobílias importadas ${ }^{47}$.

\footnotetext{
${ }^{46}$ MARINS, 1999, p. 150-242.

${ }^{47}$ Cf. CARVALHO, 2008 e SILVA; FERREIRA, et al., 2015.
} 

O multiverso dos trabalhadores

(cap. 5) 

Se a rua das elites já se distanciava do pretendido exclusivismo com o trampolim simbólico que dela faziam os remediados, a vida cotidiana dos trabalhadores que habitavam seu topo e arredores embaraçava ainda mais o intrincado campo de ações e significados que conformavam seu espaço. Esse grupo, tão diverso e volúvel quanto os outros, era conformado pelos mais pobres, com poucas posses e sobrevivência predominantemente dependente de seus esforços laborais, como assalariados ou autônomos. À semelhança de um noveau riche em relação às elites, alguns trabalhadores poderiam ter posição econômica semelhante à dos remediados menos apossados, contudo deles diferiam por seu habitus.

Tomando como referência o olhar penetrante e perspicaz de alguns autores, podemos elaborar um breve perfil a respeito da visão de mundo e modo de vida predominante entre os trabalhadores ${ }^{1}$. Para a maioria laboriosa, as perspectivas de crescimento eram bastante estreitas e a incerteza e a inconstância eram ainda mais presentes em suas vidas. Sendo assim, mantinham uma organização temporal diferente da rotina regulada pelo relógio produtivo, um dia a dia no qual o lazer e o

\footnotetext{
${ }^{1}$ Como principais referências, tomamos os trabalhos de CHALHOUB, Sidney. Trabalho, lar e botequim: o cotidiano dos trabalhadores no Rio de Janeiro da Belle Époque. Campinas: Ed. Unicamp, 2008; MELO, Victor Andrade. Lazer, modernidade e capitalismo: um olhar a partir da obra de Edward Palmer Thompson. Revista Estudos Históricos, Rio de Janeiro, vol. 23, n 45, p. 5-26, jan/jun 2010; THOMPSON, Edward Palmer. Tempo, disciplina de trabalho e o capitalismo industrial. In: THOMPSON, Edward Palmer. Costumes em comum. São Paulo: Companhia das Letras, 1998 e CARPINTÉRIO, Marisa Varanda Teixeira. Imagens do conforto: a casa operária nas primeiras décadas do séc. XX em São Paulo. In: BRESCIANI, Stella (org.). Imagens da Cidade. São Paulo: Ed. Marco Zero, 1994.
} 
trabalho eram entremeados e não rigidamente segregados como se fossem água e óleo. Apreciavam o lar, mas eram também amantes da rua, na qual imergiam em suas particulares formas de satisfação, a maioria classificadas como "incivilizadas" pelas classes superiores. Classes essas que, por realizarem predominantemente trabalhos intelectuais, também desprezavam o predomínio de seu engenho no âmbito dos ofícios manuais, embora deles se servissem cotidianamente ${ }^{2}$.

As condições materiais inconstantes e precárias também resultavam em uma concepção menos estreita de família, mais aberta a outras formas de solidariedade, fundamentais para a manutenção de elos socioeconômicos que lhes garantiriam a sobrevivência. Nesse sentido, o espaço familiar, a casa, também possuía significação e prática mais flexível, podendo servir ao mesmo tempo como espaço de trabalho e, por vezes, um meio para complementar a renda.

O habitus dos trabalhadores, naturalmente, acarretava em experiências e significações próprias da Avenida. Percepção e prática que, como veremos, fomentava conflitos, mas também inusitadas aproximações com o cotidiano higiênico e apaziguado que idealizavam os mais abastados. Como vimos, grande parte da vida das elites e dos setores médios transpassava entre paredes e muros: o trabalho nos escritórios e gabinetes, a vida familiar na residência, o lazer nos salões, parques, teatros e cafés. A rua era o espaço de conexão entre esses espaços, por onde trafegavam como transeuntes, ou faziam passeios contemplativos-exibitivos. Em ocasiões festivas, como durante corsos, desfiles e carnaval, a rua virava palco e plateia, abrigando mais longa permanência. Contudo, no tempo corriqueiro, geralmente estavam em movimento, em trânsito, mais rápido quando tendia-se atingir um ponto, mais lento quando o intuito era converter a via em passarela e admirar seus arredores.

A vida dos trabalhadores, pode-se dizer, possuía fronteiras menos delimitadas. Alheios ao aparato de espaços privados e semipúblicos de que gozavam os afortunados, grande parte de suas atividades - trabalho, diversão, socialização - se dava em espaços limítrofes à rua, cujas fronteiras da privacidade eram praticamente ausentes - como o botequim e a residência, familiar ou encortiçada -, ou nas calçadas

\footnotetext{
${ }^{2}$ FREHSE, 2011, p. 232-235.
} 
da própria via. A rua era um local de permanência, onde se formavam efêmeras salas de estar nas rodas de conversa, instáveis tribunais durante rixas e confrontos. No escuro, era o quarto dos namorados, e às claras, espaço de trabalho dos ambulantes, construtores e outros obreiros.

Suas residências, majoritariamente alugadas, quando divididas apenas entre uma mesma família, já tinham espaço exíguo. A maioria não ultrapassava os três cômodos estabelecidos pelas posturas municipais, sem contar as muitas que eram construídas à margem destas ${ }^{3}$. Nessas condições, em muitos casos, a privacidade conformada nos quartos individuais e corredores das casas mais amplas era inexistente, assim como a segregação dos espaços de descanso, serviços, trabalho e lazer ${ }^{4}$. Nesse ambiente onde tudo era junto e misturado, a casa para muitos servia apenas como um abrigo, com a finalidade de suprir as necessidades básicas dos indivíduos - dormir, comer, urinar, defecar e banhar-se. Para outros, um pouco mais providos e que não eram assalariados, a casa podia ser também um espaço de trabalho, tanto masculino, dedicado geralmente a um artifício, como feminino, usualmente ligado às tarefas domésticas de costura, cozinha, amamentação e lavação ${ }^{5}$ (FIG. 14-22).

Como bem descreveu Paulo Garcez, "tumulto" e "desordem" foram palavras comumente utilizadas pelas elites e pelo Estado para descrever a ocupação de casas e ruas pelos pobres. Contudo, estas conformavam a base de instabilidade sobre as quais, com grande competência, elaboravam suas estratégias de sobrevivência em um mundo que lhes obstruía o acesso a melhores oportunidades ${ }^{6}$. Dada a instabilidade de suas rendas perante o variável custo de vida, muitas vezes as famílias dividiam suas residências com parentes próximos e amigos ou sublocavam peças para desconhecidos ${ }^{7}$. Não à toa, o encortiçamento era condenado pelas autoridades, que viam no desconforto a ausência de controle e disciplina mantida em suas próprias

\footnotetext{
${ }^{3}$ LEMOS, 1999.

${ }^{4}$ PROST, Antoine. A família e o Indivíduo. In: PROST, Antoine e VINCENT, Gérard, História da Vida Privada: da Primeira Guerra aos nossos dias. São Paulo: Companhia das Letras, 1992, vol. 5, p. 61-115; LEMOS, 1999 e CHALHOUB, 2008, p. 184-203.

${ }^{5}$ SANTOS, 2015; CHALHOUB, 2008, p. 203-240.

${ }^{6}$ MARINS, 2006, p. 132-134.

${ }^{7}$ CHALHOUB, 2008, p. 171-203.
} 
casas, atribuindo à prática a raiz das mazelas físicas e sociais que se alastravam pela cidade $^{8}$. Para seus moradores, contudo, era uma forma de garantir a sobrevivência com parcos recursos, sem contar a oportunidade de estreitar laços de solidariedade e cooperação, fundamentais para seus malabarísticos arranjos de vida. Ainda mais diante de poderes econômicos e estatais que empregavam força na proibição do cortiço, mas que parcamente se empenhavam em viabilizar outros modos de vida, deixando-os, majoritariamente, à revelia.

Veneno para uns, remédio para outros, o encortiçamento foi corrente até mesmo nos ricos arrabaldes. No alto da Avenida, perto da Paulista, em 1919, uma senhora oferecia no Diário Español o aluguel de uma sala para casal sem filhos ou para moço solteiro ${ }^{9}$. Na mesma época, anuncia-se também no Correio Paulistano o aluguel de uma sala com alcova e entrada independente na Rua D. Veridiana ${ }^{10}$. Para além dessa mistura entre público e privado, casa e rua, havia ainda outros cruzamentos. Para os que trabalhavam na própria residência, como marceneiros, mecânicos, funileiros, lavadeiras ou costureiras, esses universos se afunilavam, pois, quando necessário, a clientela e os companheiros de trabalho adentravam esse espaço, sem uso das cerimônias que engrandeciam a separação entre o público e o privado nos palacetes e nas casas médias. Assim, diferentemente dos rijos limites estabelecidos pelo sistema de grades, jardins e portas dos palacetes e casas médias, as portadas e janelas das residências dos trabalhadores configuravam-se como membranas de alta porosidade.

Dadas as múltiplas trajetórias e atividades que se cruzavam nos cômodos das residências, algumas práticas íntimas acabavam migrando para o espaço público. Nos idos de 1924, moradores dos arredores da Praça Buenos reclamam da falta de iluminação no jardim, que se transformava "todas as noites em ponto de entrevistas

\footnotetext{
${ }^{8}$ CARPINTÉRIO, 1994; LEMOS, 1999; TELAROLLI JUNIOR, Rodolpho. Imigração e epidemias no estado de São Paulo. Hist. cienc. Saúde - Manguinhos [online]. 1996, vol.3, n. 2, p. 265-283; CORDEIRO, Simone Lucena. Os Cortiços de Santa Ifigênia: sanitarismo e urbanização. São Paulo: Imprensa Oficial e Arquivo Público do Estado de São Paulo, 2010; MASTROMAURO, Giovana Carla. Surtos epidêmicos, teoria miasmática e teoria bacteriológica: instrumentos de intervenção nos comportamentos dos habitantes da cidade do século XIX e início do XXSimpósio Nacional de História - ANPUH. Anais: São Paulo, 2011.

${ }^{9}$ O imóvel ficava na Av. Angélica, 192, "perto da Avenida Paulista”. Diário Español, "sala para alugar", 25 jun. 1919.

${ }^{10}$ Correio Paulistano, 19 set. 1911.
} 
amorosas" ${ }^{\prime 1}$. Aparentemente, fazia queixa semelhante o vereador José Oswald quando se referia com eufemismo ao "espetáculo" que diariamente se desenrolava nos fundos do Cemitério da Consolação ${ }^{12}$. Em busca da privacidade que não encontravam em casa, buscavam no véu da noite e no anonimato da escuridão a porta trancada que lhes faltava.

\section{Opostos intrínsecos}

Evidentemente, a vivacidade que os trabalhadores davam à rua por muitas vezes ofuscava as exibições das elites, conflitava com o simbolismo cultuado pelos remediados e perturbavam o conforto silencioso e idílico que ambos ansiavam. Contraditoriamente, o que majoritariamente atraía os trabalhadores para a Avenida Angélica e suas redondezas eram as oportunidades ofertadas pelos próprios abastados. Alguns buscavam trabalho nas instituições hospitalares ou filantrópicas da região ou em fábricas situadas em bairros próximos, como a Barra Funda, o Bom Retiro e os Campos Elíseos ${ }^{13}$. Essa conformação contraditória foi resultado dos idiossincráticos e ambivalentes desejos das próprias elites, que atuavam como potentes agentes imobiliários na cidade. Ao mesmo tempo em que queriam espaços reservados à moradia, queriam realizar o máximo e imediato lucro com a venda de terras. Assim, recorriam ao poder regulatório do Estado, mas ao mesmo tempo temiam o excessivo enrijecimento da liberdade de mercado. Resultado: bairros que eram para ser arrabaldes isolados acabaram abrigando atividades produtivas, atraindo para seus arredores as indesejadas populações das classes baixas, conjuntamente com seus peculiares modos de vida ${ }^{14}$.

\footnotetext{
${ }^{11}$ A Gazeta, "Praça Buenos Aires", 4 abr. 1921.

12 Anais da Câmara Municipal, 1908, p. 302.

${ }^{13}$ Hospital de Isolamento, Santa Casa, etc.

${ }^{14}$ Para uma reflexão sobre essa ambígua relação entre agentes imobiliários e o Estado, cf. CAMPOS NETO, p. 281-285. Para além do presente trabalho, principalmente em seu capítulo primeiro, outros dois
} 
Não bastasse isso, a vida nos palacetes e nas casas médias era concebida de tal forma que também demandava grandes montantes de trabalho. Não é preciso muito esforço para imaginá-lo. No interior dos palacetes, repletos de tapetes, cortinas, almofadas e bibelôs, o acúmulo de poeira se equiparava ao de um museu. Todo santo dia era um esfrega-esfrega por todos os lados para acabar com a tenacidade do pó. E quem se ajoelhava, obviamente, não era a senhora da casa, mas as criadas ${ }^{15}$. Essas também passavam o dia na cozinha, às ordens da dona, preparando as refeições, trocando os jogos de talheres e toalhas da mesa, colhendo hortaliças no quintal e matando galinhas. $O$ que não produziam em casa saíam para comprar no empório/botequim e com os ambulantes - um docinho para a sobremesa poderia ser obtido das abundantes quituteiras. E quando iam à feira, subiam ao topo da Avenida, onde muitas moravam, pois era lá que se dava o mercado que abastecia todas as casas e casarões da região ${ }^{16}$.

$\mathrm{Na}$ ausência do telefone, ainda contratavam-se os meninos de recado. E as roupas, para todos estarem a postos e bem-apessoados a qualquer momento do dia? Quem fazia os concertos e suturas eram as costureiras, e quem banhava, depurava e secava eram as lavadeiras e engomadeiras, que podiam ser empregadas da casa, mas geralmente eram contratadas por empreitada ${ }^{17}$. E os jardins? Para manter a grama cortada e os arbustos bem aparados, todo mês estava ali o jardineiro. Para conduzir a carroça ou o automóvel, o motorista. Para mantê-las em ordem, o mecânico e o funileiro. E, por fim, se a mobília quebrasse ou rachasse, era sempre bom ter à disposição o serviço de uma marcenaria.

Se Lucio Costa presumia que na morada colonial o escravo era o motor da vida doméstica, nos tempos que aqui tratamos, nem tanta coisa mudara em relação aos criados. É evidente que a instalações de esgoto, água, gás e energia elétrica, bem como

estudos corroboram tais reflexões: o caso da Barra Funda, estudado por BORIN, 2014, e o dos Campos Elíseos, analisado por MARINS, 2011.

${ }^{15}$ Sobre a divisão de tarefas domésticas entre senhoras e criadas, cf. SANTOS, 2015, p. 97-130.

${ }^{16}$ A feira da região ficava localizada na Avenida Angélica, nas proximidades da Avenida Paulista, de maneira que não interrompia o caminho do bonde e também não se amontoava em frente aos palacetes. Correio Paulistano, 17 jul. 1917.

${ }^{17}$ SANTOS, Ibidem. 
certas inovações mecânicas - máquina de costura, fogão a gás, produtos de limpeza -, facilitaram algumas tarefas. Ao mesmo tempo, é igualmente incontestável que a ascensão da fobia bacteriana, o acúmulo de mobília e a intensificação dos ritos de sociabilidade doméstica tornaram as atividades de arrumação, cozinha e limpeza consideravelmente mais complexas e trabalhosas ${ }^{18}$.

Dentro dos palacetes e casas médias moravam alguns empregados, porém, já a partir de 1900, aumenta cada vez mais o número de servidores domésticos que não moravam nos quartos de fundo nem na edícula. Pelo lado dos patrões, tal situação era favorável, pois com a passagem da escravidão para o assalariamento, os laços de serviço tornam-se menos tesos e mais tensos, transformando os criados em inimigos em potencial. Nos jornais eram numerosos os casos em que criados escapuliam da casa levando consigo dinheiro ou pertences de valor dos patrões. Por vingança, justiça ou oportunismo, a situação se rotinizou ao ponto de serem preconizados costumes de precaução até mesmo nos manuais para donas de casa ${ }^{19}$.

Para as criadas, a moradia autônoma acarretava em maiores despesas, nem sempre compensadas justamente no salário. Mas, ao mesmo tempo, lhes concedia maior liberdade para usufruir seu tempo livre, comumente castrado e controlado para os que moravam no serviço, além de um maior campo de resistência ao tratamento violento, resquício escravista que os manuais de costume também empenhavam em readequar. Por fim, a morada própria garantia maior independência para trocar de emprego e barganhar com o patrão ${ }^{20}$. Assim, mesmo com os vínculos encurtados, dada a grande demanda na região, é possível que muitos tenham construído como estratégia de sobrevivência a permanência nas redondezas dos palacetes, à espreita de oportunidades e serviços. Interessante notar que, no habitus dos trabalhadores, o labor era central na construção da identidade social feminina, e não somente os afazeres domésticos e familiares. Afinal, não era uma opção, mas uma necessidade. Sua renda contribuía igualmente, ou por vezes até mesmo mais, ao sustento familiar. Nesse

${ }^{18}$ Cf. SANTOS, Ibidem e SILVA, João Luis Máximo da. Cozinha modelo: o impacto do gás e da eletricidade na Casa Paulistana (1870-1930). São Paulo: Edusp, 2008, p. 121-192.

${ }^{19}$ Cf. SANTOS, 2015, p. 120-124.

${ }^{20}$ SANTOS, 2015, pp. 117-120 e CARVALHO, 2008, p. 305-306. 
cenário, como aponta Chalhoub, mesmo que as relações de poder entre ambos ainda fossem desiguais, a autonomia econômica permitia à mulher maior independência em relação ao marido ${ }^{21}$.

Se para as criadas a possibilidade de ascensão era difícil, tanto pela inconstância do trabalho, como pelo baixo pagamento, normalmente despendido com as necessidades imediatas, outros trabalhadores, também ligados à vida doméstica das elites, possuíam outra sorte. Assim parece ter sido a trajetória do casal de descendência italiana Maria e Umberto Pretti. O primeiro indício que temos de sua trajetória data de 1913, quando Umberto realiza pedido de ampliação da casa em que moravam na Avenida Angélica, entre a Sergipe e a Pará ${ }^{2}$. Anteriormente, parecem ter morado nas redondezas do Belém, tendo em vista que Maria ainda mantinha fortes vínculos com a paróquia daquele bairro ${ }^{23}$. A exiguidade da residência que habitavam na Angélica era tamanha que a reforma pretendia acrescentar um banheiro e uma cozinha, minúsculos, à edificação já existente (FIG. 78).

Contudo, alguns anos depois, em 1919, o casal muda-se para uma das casas geminadas de médio porte erguidas por Leonor Monteira da Silva ${ }^{24}$. Um sobrado módico, mas radicalmente mais espaçoso e vistoso do que a simplória morada anterior (FIG. 79-80). A ascensão é marcada também pela mudança de posição na Avenida, agora nas proximidades da praça Buenos Aires. Nesse mesmo ano, pedem à Prefeitura uma licença para estacionamento na frente de sua nova residência, possivelmente pela compra de um automóvel. O rápido progresso de seus rendimentos parece estar associado com suas capacidades manuais, de grande valia naquela vizinhança. Maria era costureira, e devia prestar serviços às famílias abastadas das redondezas, lembrando que, naqueles tempos, o consumo de roupas em lojas não era difuso como hoje, nem o descarte era frequente. O mesmo valia para toalhas e cortinas, para as

\footnotetext{
${ }^{21}$ CHALHOUB, 2008, p. 203-211.

22 OP-1913-000.253. Fundo de Obra Privadas do AHMSP.

${ }^{23}$ Em 1917, Maria participa de requerimento para oratório particular na Paróquia do Belém junto à arquidiocese de São Paulo. Correio Paulistano, “Crônica religiosa”, 10 out. 1917.

${ }^{24}$ É possível que tenham apenas alugado a princípio. Contudo, pela lista de impostos prediais de 1927, sabemos que a essa altura Humberto já era proprietário do imóvel. Correio Paulistano, 6 jun. 1927 e Correio Paulistano, 7 jun. 1927.
} 
quais sempre eram constantes as solicitações de confecção e manutenção ${ }^{25}$. Umberto, por sua vez, era marceneiro, e por vezes pode ter se ocupado de reparos e construção das mobílias da vizinhança, bem como ter tomado parte de pequenos trabalhos relacionados à construção civil, como o "barracão" que foi encarregado de construir no número 340 da Avenida. A ligação dos dois com a região se evidencia quando, mesmo com maiores rendimentos, nenhum deles retira suas oficinas da Angélica, que se mantém no mesmo imóvel que habitam até ao menos $1928^{26}$. Em 1929, Humberto chega até mesmo a ampliar seu universo de negócios, investindo dividendos em um cinema no Bom Retiro que, contudo, acaba por lhe dar prejuízo, aparentemente, por conta das trapaças de seu sócio na empresa ${ }^{27}$.

Biaggio Priesco, um dos primeiros moradores da região, chega à Avenida em 1897. Em uma casa alugada, constrói sua casa/ferraria, após alguns desentendimentos com o senhorio, que, como vimos anteriormente, desconfiara que sua morada estava infestada com pestilências ${ }^{28}$. Ao que consta no seu pagamento de impostos, sua especialidade era o reparo de carroças, uma grande demanda daqueles arrabaldes na época, como podemos ver pela grande quantidade de cocheiras que acompanhavam as construções de casas médias e palacetes até 1910. Apesar do advento do automóvel, ainda na década de 1920, Biaggio permanece no mesmo imóvel realizando a mesma atividade, provavelmente encarregando-se das carroças que ainda serviam ao transporte de cargas e à locomoção de remediados menos enriquecidos ${ }^{29}$. Seu sucesso, embora não tão portentoso como o dos Pretti, é assinalado não só pela resiliência de seu negócio, mas também por uma singela ampliação que faz em seu prédio em 1914; pela pequena casa de aluguel que compra na Rua Esmeralda, número 8, na Aclimação ${ }^{30}$; bem como pela trajetória de seu filho, que, provavelmente após anos de

\footnotetext{
${ }^{25}$ Cf. CARVALHO, 2008 e SANTOS, 2015.

${ }^{26}$ Sabemos disso através da lista de impostos por “indústrias e profissões” daquele ano, na qual, é interessante notar, ambos contribuíam com quase a mesma quantidade - ela, 280\$000, ele, $320 \$ 000$. Correio Paulistano, 9 mai. 1928.

${ }^{27}$ Diário Nacional, “Tentou lesar o sócio”, 18 jun. 1929.

${ }^{28}$ O Estado de São Paulo, jun., 1899.

${ }^{29}$ Lista de impostos por “indústrias e profissões”. Correio Paulistano, 9 mai. 1928.

${ }^{30}$ Em 1927, Biaggio paga imposto predial por um imóvel na Rua esmeralda, número 8. Comparado à taxa cobrada de outras edificações da região, pudemos constatar que a sua era modesta, pois chegava a pagar
} 
trabalho com o pai, consegue juntar dinheiro suficiente para comprar um terreno na rua dos Pinheiros, onde passa a manter própria oficina de concertos de automóveis ${ }^{31}$.

Como Pretti e Priesco, outros também gozaram de sorte semelhante na sobrevivência, bem como nas pequenas ascensões. Após quase vinte anos trabalhando como encanador na Avenida, Nichola Paschoa reuniu recursos suficientes para que sua filha arranjasse bom casamento com Homero Simões, filho do tenente da Força Pública do Estado, Joaquim Ferreira Simões. O taberneiro Natale Croce, comprou com seus rendimentos terreno na Vila Emma, um pequeno loteamento a leste do Ipiranga, e construiu uma casa de aluguel na Rua Regente Feijó ${ }^{32}$. Juntavam-se a esses os tantos outros que não nos restaram mais do que o nome, o endereço e a profissão, mas que também foram protagonistas, com maior ou menor sorte, no intenso mercado de serviços da Avenida. Eram construtores, como Marão de Oliveira Cunha e Penino de Almeida; costureiras, como Alcine de Lucca e Maria do Carvalho; taberneiros, como José Laterza, Antonio Freitas de Andrade e Manuel Joaquim de Carvalho; comerciantes de plantas, carvão e frutas, como Carlos Frangi, Ferdinando Behmorini e Francisco Penna; funileiros, como Paschoal del Nero; mecânicos, como Pedro Sapofino e os irmãos Boharer; e proprietários de bombas de gasolina, como Antonio Fidelix. Isso sem falar dos operários que eram empregados em fábricas no Centro e nas redondezas, como Antonio Monica, Pedro Lanzelotti, Francisco Caiuro, Nicola Baola, Romulo Ferrari, além das dezenas de anônimos que por ali devem ter passado suas aventuras de sobrevivência à margem dos registros públicos e jornalísticos ${ }^{33}$.

\footnotetext{
quase dez vezes menos do que o imóvel com maior contribuição e duas a quatro vezes menos do que a média. Correio Paulistano, 6 jun. 1927 e Correio Paulistano, 7 jun. 1927.

${ }^{31}$ Em 1927, Antonio Priesco compra terreno em pinheiros (Correio Paulistano, 23 nov. 1927), local onde provavelmente constrói sua oficina de conserto de automóveis, pela qual paga taxas por "indústrias e profissões”, com endereço na Rua dos Pinheiros, 220. Correio Paulistano, 9 mai. 1928.

${ }^{32}$ Correio Paulistano, 24 abr. 1919; Correio Paulistano, 8 mai. 1928.

${ }^{33}$ Lista de impostos por "indústrias e profissões”. Correio Paulistano, 9 mai. 1928.
} 


\section{As fronteiras da cultura, os limiares da lei}

Enquanto alguns buscavam sustento pelas vias aprovadas pelo Estado e pelo habitus dominante das elites, outros tentavam a sorte à sua margem. Difícil apreender a totalidade dos motivos que levavam tantos a esses caminhos alternativos, mas algumas delas podemos estimar. Deixando de lado questões morais e psíquicas, distante da alçada de nossas fontes, pensemos no universo social que habitavam. A população trabalhadora era composta por milhares de ex-escravos, migrantes e imigrantes que, provindos dos meios rurais, nem sempre se adequavam às novas regras e ritmos impostos na metrópole. Se para muitos as novas estratégias de vida empregadas nesse meio - assumir a rotina disciplinada das fábricas, encontrar meio de vida no comércio, firmar pequena clientela para um serviço - foram facilmente assimiladas, não é surpreendente que para outros, os mais velhos, por exemplo, a adaptação tenha sido mais árdua, e mesmo quase impossível. Eram filhos de um outro tempo, e o desterro, material e social, exigia novas habilidades, novos cálculos, novas sensibilidades e novas inteligências. Sem lugar no universo do trabalho e do salário, restava-lhes a marginalidade da criminalidade, da malandragem ou da mendicância.

Um lugar que, aliás, não era ocupado de maneira pura ou plena. Muitos oscilavam ao longo de suas vidas entre as fronteiras da lei: alguns, por não encontrarem satisfação plena na rotina disciplinada e contínua do trabalho (preferindo o conforto da bebida e da vadiagem); outros, por serem surpreendidos por repentinas desavenças, demissões e outros acasos que acabavam por deixar-lhes em condição de transitória precariedade; sem falar dos idosos que não haviam feito economias, ou daqueles que, por azar maior, acabavam sendo vítimas de acidentes, mentais e psíquicos, que não lhes permitiam dar continuidade à vida laboral.

Para muitos dos que chegavam à condição de marginalidade, a pompa de Higienópolis poderia ser amedrontadora, mas para outros, sem dúvida, era muito atraente. Para a mendicância ou a gatunagem, a ostentação dos palacetes e a fama afortunada do bairro traíam seus moradores. Sob os olhos da malandragem, 
convertiam-se em luminosos chamarizes de oportunidade. Dentre os casos pontuais de roubos de joias, relógios e pratarias, correntes nas páginas diárias dos jornais, o bairro das elites foi escolhido como morada de um dos mais renomados ladrões da cidade: Frederico Gobbi ${ }^{34}$. Sagaz e engenhoso, segundo as descrições do Correio Paulistano, o mecânico balofo, um exímio profissional, em dado momento de sua vida, decidira especializar-se no arrombamento de cofres. Talvez por estar cansado da labuta, talvez por certo gozo de rebeldia, protagonizara grandes roubos a bancos, escritórios e lojas entre 1913 e 1916, quando foi finalmente preso. Não chegou a enriquecer, contudo, nesse ínterim, alugava uma pequena residência na Praça Buenos Aires, talvez por ser um local ermo, pois localizado nos confins da cidade, insuspeito e de aparente tranquilidade ${ }^{35}$. Após o roubo de uma grande joalheira, percebeu que a polícia o localizara e fugiu da cidade. Poucos meses depois, após gastar toda sua renda, volta para tentar recuperar sua parte das joias que deixara com um comparsa, quando acaba sendo preso.

Gobbi foi um caso midiático, mas a vida de tantos outros, mesmo que dentro ou fora da lei, permanecia à margem das páginas dos jornais, junto ao complexo cultural que embasava seu cotidiano. E quando era retratada, nos jornais analisados, a vida dos trabalhadores era rotineiramente julgada e compreendida a partir do habitus dos abastados, que a enquadrava sob a ótica da ameaça, da desordem e da inferioridade. Assim, nosso acesso ao seu universo cultural precisa ser depurado dos discursos pejorativos que o envolviam. Os mecanismos e astúcias dessas representações, além de transcenderem os objetivos de nossa reflexão, já foram explorados por muitos outros autores $^{36}$. Utilizando esses trabalhos como filtro, concentrarei meu empenho em destilar os discursos da mídia em busca dos sentidos e usos que os trabalhadores

\footnotetext{
${ }^{34}$ Correio Paulistano, "Odisseia de um ladrão", 20 dez. 1916.

${ }^{35}$ Como explicitei no capítulo primeiro, a ocupação da Avenida, bem como de seus arruamentos transversais, foram lentos e graduais. Sendo assim, há de se compreender a dual percepção daquele espaço como tranquilo e ermo. A região da Praça Buenos Aires, especificamente, configurava um limiar da cidade, e à altura, como veremos a seguir, ainda encontrava-se cerrada ao público pela municipalidade, que tampouco lhe prestava os serviços de manutenção, materializando no capim alto e no descaso com a limpeza o seu abandono daquele espaço.

${ }^{36}$ CARPINTÉRIO, 1994; CORDEIRO, 2010; FREIRE, 1989.
} 
davam à rua, deixando em segundo plano os debates a respeito dos interesses envolvidos na representação da pobreza pelos ricos.

Percorrendo as páginas d'O Correio Paulistano, nota-se rapidamente que o trabalhador só se tornava notícia quando envolvido em uma desgraça. Para além das óbvias repreensões em casos de roubos e furtos, noticiavam-se com frequência tragédias em que eram protagonistas. Contidas em geral na coluna de "Desastres e Ferimentos", figuravam no diário pequenas ocorrências - um acidente envolvendo automóveis ou estapafúrdios tropeços, um pequeno acidente de trabalho, a batida forte de um membro, um simples corte no dedo - ou ainda outras de maior expressão, que por vezes tornavam-se matérias independentes, embora sempre de curta extensão.

Na rua Piauí, imediações da Avenida Angélica, o pedreiro Sebastião dos Santos, de 22 anos de idade, morador à rua Augusto de Queiroz ${ }^{37}$ n. 16, palestrava ontem, às 11 e meia da noite com dois companheiros, quando por ali passou um grupo de portugueses, do qual fazia parte o carpinteiro Alipio Ignacio Pereira, de 40 anos de idade, morador à rua Frei Caneca n. 87.

Alipio sendo inimigo de Sebastião, provocou-o juntamente com os seus companheiros. E porque este pretendesse reagir o apedrejaram, tendo um deles lhe arremessado um tijolo na boca.

Sentido-se ferido, Sebastião sacou uma garrucha e desfechou tiro contra o grupo de portugueses, tendo a bala penetrado o hipocôndrio direito de Alipio $^{38}$.

Desse desencontro repentino, deixando de lado o sensacionalismo da narrativa, podemos entrever dois fatos. Primeiramente, para os contendes e seus respectivos grupos, bem como para tantos outros pedreiros, carpinteiros e marceneiros que moravam ou trabalhavam na região de Higienópolis, suas ruas não eram apenas um local de trânsito, mas um espaço contíguo ao trabalho. Contratados nas obras que pululavam pelo bairro, realizavam suas pausas sentados às calçadas, ou palestravam entre colegas e passantes, lembrando que em sua rotina a divisão entre lazer e trabalho era bem menos definida do que nos habitus das outras classes. O mesmo valia para os donos de botequim, vendedores ambulantes, carroceiros, funileiros e outros tantos comerciantes e artífices que por ali se instalavam ou transitavam. Com seus corpos,

\footnotetext{
${ }^{37}$ Via que existia no Vale do Anhangabaú.

${ }^{38}$ Correio Paulistano, “Tiro de garrucha”, 23 fev. 1913.
} 
vestes e gestos, ocupavam o espaço da rua, contrastando com os modos refinados das classes altas que passavam, interferindo no seu rito de exibição-visão, e até mesmo invadindo com irruptivas gargalhadas ou pelo alto tom de uma conversa a paz que aquelas procuravam tecer em seus ninhos de conforto. Sem contar os namoricos de calçada que deviam se desenlaçar com as criadas de cada casa, que fugiam do serviço para o portão assim que o patrão se virava ${ }^{39}$.

Em meio a esses momentos de descontração na rua, que muitas vezes se estendiam também aos botequins da redondeza, muitas vezes irrompiam conflitos: bate-bocas e xingamentos que algumas vezes se resumiam a trocas de ofensas, mas em tantas outras resolviam-se apenas com o clímax da agressão física. No Correio Paulistano, esses ocorridos eram geralmente retratados como atos bárbaros, incidentes com motivações supérfluas, movidos pela embriaguez ou pela brutalidade e incivilidade dos envolvidos. Contudo, a partir das considerações de Sidney Chalhoub (2008) sobre o cotidiano dos trabalhadores no Rio de Janeiro da mesma época, podemos aferir um significado mais profundo aos desentendimentos que se desenrolavam na rua.

Avessos à solução de divergências por meio judicial, que muitos consideravam injusto devido à perseguição incessante dos tribunais e das tropas policiais à população de baixa renda, os encontros violentos não eram percebidos pelos trabalhadores como um ato fora da ordem, mas uma forma legítima de solucionar conflitos. Longe do despropósito, as agressões físicas comumente ocorriam após uma sequência de sucessivos atritos entre as partes, que ao se prolongarem, acabavam resultando no desafio como último desenlace possível. Como Alipio e Sebastião, que já nutriam rivalidade há tempos, muitos outros tiveram seus acertos na Angélica ou em suas proximidades. Assim, o carroceiro Francisco Ferrari, morador da Avenida, meteu-se em briga com Antonio Procida nas proximidades de sua casa; Pedro Lanzelotti, também habitante da Angélica, deu duas navalhadas no rosto de José de Gilli, um companheiro de fábrica, no botequim vizinho à sua casa; sem falar do pedreiro

\footnotetext{
${ }^{39}$ Além do que observamos nos jornais, Chalhoub retrata alguns casos envolvendo patrões, criadas e namorados. CHALHOUB, 2008, p. 203-211.
} 
Paschoal Pagliucci, também ali residente, que trocou tiros com o marceneiro Roque Calendano em frente ao Hospital de Isolamento.

Não à toa, a rua era o palco primordial desses eventos. Era ali onde os opositores se encontravam, pois a calçada em si era um espaço de sociabilidade e permanência, mas também um dos poucos espaços da cidade que "não era de ninguém”. Nos ambientes de sociabilidade onde havia um proprietário, como os botequins, esse comumente separava a contenda ou comunicava à polícia, temeroso de que a quebradeira se estendesse ao seu patrimônio. $\mathrm{Na}$ rua, não havia interventores, exceto nos casos em que um dos espectadores decidia manobrar a ocasião, o que nem sempre era comum, pois, pelo que observa Chalhoub, a norma compartilhada pela população trabalhadora em geral legitimava o enfrentamento.

Ao que parece, essa conduta era partilhada também pelos remediados de pequena posse. Contudo, distantes das variadas causas e causos dos trabalhadores, esses possuíam um motivo frequente para os ajustes: o descumprimento do aluguel e o mando em suas posses. Enquanto os mais ricos se valiam da instituição policial e judicial para pressionar os locatários, entre os menos providos, os acertos eram muitas vezes feitos pelas próprias mãos do senhorio. Assim o fez José Francisco, morador do 362 da Angélica e proprietário do 421, ambas casas de tamanho módico, nas proximidades da Paulista. Seu inquilino era o chauffeur Luiz Spadonl, de trinta e dois anos de idade, que ali morava com sua esposa havia apenas quatro meses. Por motivos que não foram esclarecidos à reportagem, há algum tempo José havia começado a pressionar o motorista para que desocupasse o prédio. Às três da madrugada de um sábado, os dois se encontram na rua, e teve início o bate-boca. Luiz argumentou que não poderia deixar a casa, pois não possuía dinheiro para o carreto, resposta que foi suficiente para que José sacasse sua arma e desferisse um tiro nas costas do inquilino, fugindo logo em seguida ${ }^{40}$.

O mesmo sucedeu entre Fortunato Barbosa, morador do 301 da Angélica, e o jardineiro Benedicto Francisco de Almeida Salles, locatário de seu casebre no número 4 da Rebouças. Por conta de sucessivos atrasos de aluguel, cujo acerto já deveria ter

\footnotetext{
${ }^{40}$ Correio Paulistano, “Agressão a tiro”, 3 jan. 1917.
} 
sido cobrado verbalmente algumas vezes, Fortunado aliciou seu comparsa Mauricio Soares e, juntos, ambos encurralaram Benedicto enquanto esse passava pela Rua Saracura Grande ${ }^{41}$, intimidando-o com facas, que serviram para dar-lhe pequenos cortes no rosto, no pescoço e nos pés ${ }^{42}$. Após dois anos, Fortunato foi absolvido pelo Júri Popular, demonstrando que a violência gozava de certa legitimidade até mesmo perante as instituições oficiais ${ }^{43}$.

Pelos relatos do Correio, onde predominavam os juízos de frivolidade a bestialidade dos disputantes, não é difícil imaginar como esses eventos eram recebidos pela vizinhança. Se a presença permanente dos trabalhadores nas ruas já devia incomodar alguns - seja pelo seu comportamento peculiar à sedosa sociabilidade nutrida pela alta cultura, seja pelos temores sanitaristas, que projetavam no corpo dos despossuídos o fantasma das bactérias -, quando se desenrolavam as contendas, muitos deviam perder os nervos. O ódio, o medo, a surpresa, o desespero certamente foram algumas das retumbâncias que repercutiam no corpo dos encastelados ou dos que por perto transitavam.

Essa mistura de ringue e tribunal, contudo, era momentânea. Embora pelas ruas muitos obreiros, senhorios e inquilinos cruzassem olhares ou trocassem desavenças, não era sempre que descambavam para o encontro físico, e tampouco era apenas de conflitos que se fazia a vida dos trabalhadores. Nos interstícios que abriam na rotina do labor ou nos extremos do dia, reuniam-se no que poderia ser considerado o centro nervoso de seu cotidiano: o botequim. Ali, acontecia de tudo um pouco. Vendiam-se alimentos e cigarros. Transmitiam-se as notícias no balcão ou de ouvido: uma nova oportunidade de emprego, uma nova atrocidade. Liam-se jornais em voz alta. Assentavam-se os jogos de aposta. Às vezes tocavam pequenos grupos de música. Essas atividades, para além da sociabilidade, eram o grande reduto de prazer dessa população, principalmente para os homens, que encontravam ali o seu conforto.

\footnotetext{
${ }^{41}$ Infelizmente, não foi possível precisar a localização dessa via. Contudo, a partir de nossas aferições, o mais provável é que estivesse situada nas proximidades do Vale do Rio Saracura, por onde hoje passa a Avenida Nove de Julho, nas proximidades do Bexiga.

${ }^{42}$ Correio Paulistano, "Desavenças e agressões", 3 dez. 1913.

${ }^{43}$ Correio Paulistano, “Tribunal do Júri", 30 dez. 1913.
} 
Na Angélica, os botequins até que eram variegados: em 1928, houve ali pelo menos quatro coletas de imposto para "botequim e cigarros", sem contar os que foram abertos e fechados anteriormente ${ }^{44}$. Certamente não atendiam exclusivamente à população que morava em seu topo, pois nem todos esses estabelecimentos estavam ali situados, estreitando ainda mais o cotidiano de trabalhadores e abastados. Os botequins de Manoel J. de Carvalho e de Antonio Freitas de Almeida, por exemplo, respectivamente no número 147 e 171, ficavam nos quarteirões próximos à praça Buenos Aires, provavelmente atendendo aos que trabalhavam na Avenida e arredores - ambulantes e construtores -, bem como os trabalhadores que moravam em suas redondezas, ombro a ombro com uma das diletas áreas de contemplação e passeio dos abastados, muro a muro com palacetes, escritórios e seus pomposos frequentadores.

Nos botequins, os trabalhadores tomavam cafés, cervejas e alcoólicos, sozinhos ou na companhia de amigos e desconhecidos, momento crucial na sociabilidade, no qual a troca de confidências e informações consolidava redes de troca, favor e trabalho. Da mesma maneira que os afortunados se reuniam em salões e clubes para fortalecer laços de compadrio, os trabalhadores teciam seus circuitos na rua e no botequim, na esteira de seus próprios ritos: fumar cigarro, tomar um trago, duelar no jogo de cartas, etc. Era a partir desses encontros que, para além da diversão, mobilizavam importantes estratégias para a sobrevivência: a negociação de uma sublocação de bom preço, uma indicação de serviço e uma oportunidade de negócio, regular ou marginal às leis estabelecidas pelo Estado.

Mas não era só no botequim que se divertiam. Havia também as ocasiões festivas, que, para os imigrantes italianos, muitas vezes culminavam em um rito pouco usual à tradição da alta sociedade nacional: o cortejo fúnebre. Nessas ocasiões, a passarela das elites era protagonizada e desfrutada pelos desabastados. Conformando a principal conexão dos bairros da expansão a Oeste com as duas principais necrópoles da região, o Araçá e a Consolação, a Angélica era caminho inescapável para a passagem de cortejos fúnebres que provinham das Perdizes, da Lapa, da Barra Funda, de Santa

${ }^{44}$ Lista de impostos por "indústrias e profissões". Correio Paulistano, 9 mai. 1928. À época também constavam ali três armazéns, outro espaço onde comumente os trabalhadores se encontravam e socializavam. 
Cecília, dos Campos Elíseos e do próprio Higienópolis. Um bairro isolado, mas com importantes ligações para toda a cidade, eis uma grande contradição. E no dia a dia, os que se iludiram com um sonho de idílico encastelamento, certamente ficavam surpresos com o agito que tomava conta da Avenida.

$\mathrm{Na}$ morte, ricos e pobres se igualavam, ao menos no direito de ocupar a via com suas condolências. De acordo com reminiscências de Yan Almeida Prado, coletadas por Maria Cecília Naclério Homem, os enterros dos italianos eram precedidos por bandas, seguidos pela turba vibrante, regados a bebidas alcoólicas, que eram abastecidas nos botecos ao longo do caminho ${ }^{45}$. Relato semelhante é encontrado nos contos de Brás, Bexiga e Barra Funda, de Alcântara Machado, através do qual podemos vislumbrar uma pequena fração dessa experiência. Muitos dos trabalhadores encantavam-se com o mundo das elites e, na ocasião dos cortejos, talvez se revestissem também de certo brio exibicionista. Esse é o caso do menino Gaetaninho, que sonha em andar de carro em um féretro com "muita gente nas calçadas, nas portas e nas janelas dos palacetes, vendo o enterro", mas sobretudo admirando a sua apurada aparência $^{46}$. O mesmo passa na mente do pequeno Pepino, que acompanhava o cortejo de uma criança e, em dado momento, insiste com uma das moças em carregar o caixão, recebendo de resposta um belo puxão de orelha: “- Puxa, que fiteira! Só por que a gente está chegando na Avenida Angélica. Que mania de se mostrar, que você tem!" ${ }^{47}$. As camadas de interesse que moveram Machado a retratar tais eventos nos são ainda desconhecidas. E, no momento, aprofundar tal discussão seria um desvio muito grande em nosso percurso. Aqui vale apenas notar que, apesar de ser uma ficção, as narrativas pertencem ao gênero da crônica, que por definição guardava grandes compromissos em relatar fatos concretos, ainda mais em um livro que se anunciava jornalístico em seu subtítulo: "Notícias de São Paulo" ${ }^{48}$. Se é bem provável que

\footnotetext{
${ }^{45}$ PRADO, Yan de Almeida apud HOMEM, 1980, p. 100.

${ }^{46}$ MACHADO, Antônio de Alcântara. Gaetaninho. In: Brás, Bexiga e Barra Funda, 1927, p. 4. Obra em domínio público, disponível em: http://www.dominiopublico.gov.br/download/texto/bi000005.pdf (último acesso em fevereiro de 2017)

${ }^{47}$ Idem. O monstro de rodas. In: Ibidem, p. 40.

${ }^{48}$ Cf. SANTOS, Isabel dos. Brás, Bexiga e Barra Funda de Alcântara Machado: uma narrativa-registro da cidade de São Paulo. Dissertação (Mestrado) - PUC-SP, São Paulo, 2010 e PINTO, Maria Inez Machado
} 
nominalmente Gaetaninho e Pepino não existiram, não é difícil imaginar que o fascínio que nutriam pela passarela das elites ocupasse os corações e mentes de outros jovens ou adultos de carne e osso. Ainda mais nesse peculiar momento em que estes, que estavam sempre no fundo da plateia, subiam ao palco, trazendo para si os olhos daqueles que por tantas vezes viram desfilando naquela mesma passarela.

Não obstante, há igualmente indícios de que outros nutriam sentimento oposto. Se não chegaram a concretizar ações efetivas de depredação material aos palacetes, como as que ocorreram por parte do operariado parisiense durante o século XIX, ataques simbólicos foram efetivamente $\operatorname{concretizados}^{49}$. N’O Combate, por exemplo, é possível identificar uma série de reportagens nas quais a compra de palacetes, bem como a conformação dos espaços públicos de Higienópolis, foi retratada como resultado de enriquecimento ilícito e favorecimento obsceno. Assim, por vezes, valendo-se do imaginário do bairro aristocrático, a redação criticava os investimentos desiguais nos "bairros ricos" e nos "bairros pobres" da cidade. Ao reportar um novo empréstimo realizado pela Prefeitura em 1918, o redator anônimo aproveita para evidenciar sua crítica. O texto inicia com uma descrição lamuriosa da condição do calçamento dos "bairros pobres", afirmando: "quem percorra as ruas (...) não pode deixar de achar necessário o calçamento de áreas inteiras que lá estão cheias de bons prédios cujos moradores sofrem horrivelmente com o lamaçal”. Em seguida, prossegue:

Mas, em compensação, fica-se a perguntar: porque não têm calçamento essas
ruas, assim povoadas, se na proximidade da Avenida Paulista e no
aristocrático Hygienopolis há quadras inteiras muito bem calçadinhas, à
espera do primeiro palacete que por lá construir um membro no nosso
impagável high-life de plutocratas ? $^{50}$

O texto segue, afirmando que, como a maioria da população da cidade constituída por "pobres", "um quarteirão qualquer no Braz concorre melhor para os cofres

\footnotetext{
Borges. Crônica cinematográfica do cotidiano: Alcântara Machado e os impasses do modernismo. Varia História, Belo Horizonte, $\mathrm{n}^{\circ}$ 24, Jan, 2001, p.190-209.

${ }^{49}$ PERROT, Michelle. Maneiras de morar. In: PERROT, Michelle (org.). História da Vida Privada: da Revolução Francesa à Primeira Guerra. São Paulo: Companhia das Letras, 1992, p. 284-302.

${ }^{50}$ O Combate, 6 abr. 1918.
} 
municipais do que qualquer quarteirão de Hygienópolis ou da Avenida [Paulista]" ${ }^{51}$. A percepção de relações promíscuas entre o poder público e as elites na materialização do bairro foi igualmente explicitada no abaixo-assinado dirigido em 1911 à Câmara pelos moradores do alto da Angélica, que reclamavam da desigualdade de investimentos ao longo da via ${ }^{52}$. Assim, não é difícil imaginar que, mesmo que não tenham sido leitores d'O Combate, alguns dos trabalhadores que vivenciavam a rua da Avenida não nutrissem o mesmo fascínio ou simpatia pelos palacetes e pela paisagem límpida das elites. Alguns, menos racionais e desalinhados aos desejos projetivos de muitos historiadores de ver na vida do trabalhador um embrião revolucionário, talvez nutrissem desgosto pelos palacetes, mas apenas como uma forma agressiva de inveja. Afinal, os patrões detinham poder e riqueza que a eles era ensinado a cultuar. Contudo, seu acesso lhes era proibido. Em tantos outros, pode ser que conviviam ambos sentimentos.

O veneno das palavras por vezes escorrera para a vida cotidiana. A irreverência e agressão dos roubos pode ser interpretada como um desdobramento material dessa violência, fosse sua origem em um argumento ético e rebelde ou em uma reação emotiva. Talvez ocupar as ruas, ver o espanto dos ricos perante os seus gestos, também fosse vivenciado como um prazer agressivo por alguns trabalhadores, uma pequena inversão de poderes.

\footnotetext{
${ }^{51}$ Sem dúvida, o estudo das intenções que perpassavam o editorial do jornal seria fundamental para compreender profundamente essa campanha difamatória. Contudo, outra vez, isso demandaria recursos temporais e espaciais transcendentes aos objetivos da presente pesquisa. Aqui, essa especulação serve apenas para suscitar que, nas práticas da rua, enquanto nos corações e mentes de alguns trabalhadores habitavam a admiração pela passarela das elites, o desejo de simular seus ritos ou penetrar em seu elegante cotidiano, talvez convivessem, dentro dos mesmos indivíduos ou entre diferentes sujeitos, as antipatias e desgosto pelos mesmos símbolos e materialidades.

${ }^{52}$ Refiro-me aqui aos debates em torno do calçamento da via, que foram apresentados no princípio do capítulo segundo deste trabalho.
} 


\section{Irrequieta placidez}

Aproximamo-nos do fim. Após tantas voltas e revoltas pela Angélica, o leitor pode estar se perguntando o que foi feito daquela praça, a Buenos Aires, tão marcante na Avenida e que até aqui não mereceu mais do que poucas linhas, reduzidas a menções episódicas e suplementares. Não fiquemos afoitos, é chegada a hora e talvez não houvesse oportunidade mais precisa para adentrarmos em seus meandros do que após nosso longo percurso pela Avenida dos trabalhadores. Isso porque a potência dos contrários e dos atritos tomou aqui suas formas mais extremas e extraordinárias.

Este é um capítulo singular e intenso, praticamente sintético dos caminhos tortuosos, conflituosos e contraditórios que marcaram nosso percurso pelo "fazer-se" da cidade. A constituição dessa praça não só nos permitirá observar novas formas para as tensões já analisadas, como também aprofundar em novas dimensões as intrincadas tramas simbólicas, materiais e relacionais em que foram travadas.

Assim como a maioria das áreas verdes da cidade concebidas à época pela municipalidade, a Buenos Aires foi projetada a partir dos anseios idílicos, sanitaristas e exibitivos das elites e do Estado ${ }^{53}$. As primeiras tentativas de sua implementação datam de 1909. Contudo, é apenas com a elaboração de um plano de melhoramentos pela Diretoria de Obras Públicas em 1912, com auxílio de Joseph Bouvard, que sua concretização ganha contornos efetivos. No plano apresentado pelo engenheiro francês, a escolha da localidade justificava-se pela preservação de vistas externas ao Centro da cidade, onde seria realizado o portentoso conjunto do Anhangabaú e dos vales mais enfáticos da região. Com intenção semelhante, recomendava a construção de um belvedere na Rua Rio de Janeiro, de frente para o Vale do Pacaembu; outro na Avenida Paulista, aberto ao fundo do córrego Saracura; e, por fim, a criação do Parque da Água Branca, com vistas para o Tietê $\hat{e}^{54}$.

\footnotetext{
${ }^{53}$ Cf. capítulos primeiro e segundo desta dissertação.

${ }^{54}$ Anais da Câmara Municipal de São Paulo, 1912, p. 501.
} 
Contudo, a nobre intenção de dotar a cidade de espaços belos e agradáveis atrelava-se indignamente aos interesses que circundavam a região "aristocrática" da cidade, preferida em detrimento de outras admiráveis paisagens - como o vale do córrego Itororó ou a Várzea do Carmo. No caso da Buenos Aires, com a desapropriação de vasta área de Higienópolis, ganhava Germaine Burchard, que ainda possuía grande quantidade de terrenos ociosos na Angélica ${ }^{55}$. Mais um passo no árduo empenho em valorizar a área como exclusiva e legítima detentora da alcunha de “aristocrática". Lucravam igualmente as elites, que mesmo providas da amplitude de seus jardins, alguns beirando a dimensão absurda de pequenos parques, ganhavam um novo espaço para suas sociabilidades exibitivas, assim como para a realização de seu apaziguado lazer contemplativo. Por fim, com as vistas panorâmicas e o rebuscado desenho paisagístico, triunfava o Estado, com um novo cartão-postal, em inserir a capital no rol das "grandes cidades sul-americanas" 56 - sentido que encontrava sua máxima representação no batismo da praça, que ecoava a glória da "Paris das Américas" (FIG.10).

Buenos Aires era também uma homenagem explícita aos intendentes argentinos que visitavam a cidade em 1913, quando a praça foi inaugurada. Um batismo, em certa medida, adulador. Ainda mais porque os portenhos foram praticamente os únicos a visitarem o jardim ainda naquela década. Após sua abertura para o mundo, fecharamse os portões para a cidade ${ }^{57}$. Franqueado ao público apenas no final de 1918, a delonga era justificada pela municipalidade pelo atraso do Governo do Estado em prover o parque de iluminação e pela indecisão da Diretoria de Obras frente a três possibilidades de pavimentação. Mesmo que verídicos, eram álibis enfadonhos para explicar um hiato de cinco anos. Mais plausível parece atribuir esse atraso à política de austeridade aplicada por Washington Luís a partir de 1914, que afetara também a abertura do mirante da Avenida Paulista. Uma postura que parecia ter respaldo não somente do PRP, mas também das elites locais, uma vez que, durante quatro anos, o

\footnotetext{
${ }^{55}$ Afinal, ela vendeu um quarteirão inteiro para a Prefeitura construir a Praça e, como pudemos constatar, à altura, poucas das transversais da Avenida Angélica haviam sido concretizadas.

${ }^{56}$ Anais da Câmara. Ibidem.

${ }^{57}$ Anais da Câmara Municipal, Requerimento 23, 1917, p. 26.
} 
silêncio sobre o trancamento da Praça prospera na Câmara, no Correio Paulistano e n'O Estado ${ }^{58}$. É apenas em 1917, quando ocorre a polêmica recondução do prefeito, provocando grande insatisfação em muitos políticos do PRP, que o caso vem à tona ${ }^{59}$. Nesse ano, José Piedade dá inicio a uma cruzada pela abertura do jardim, valendo-se dela como símbolo do descaso e dos desmandos do alcaide. Com sua postura justicialista, o vereador, que voltava à casa após três anos afastado por motivo de saúde, talvez buscasse também angariar poder pela simpatia dos abastados moradores de Higienópolis. Novamente, vemos os projetos da cidade tendo seu destino guiado antes por seu aspecto simbólico do que prático. É somente após o agravo de uma séria crise política na Câmara, encabeçada pelo próprio Piedade, que as obras finais da Praça são concretizadas e o espaço é finalmente franqueado ao público.

Como não poderia deixar de ser, rapidamente a Buenos Aires caiu no gosto das elites. Celebrada em textos e postais, a praça aparecia formosa, uma extensão natural da atmosfera "aristocrática" e higiênica da Angélica. Era corre-corre das crianças ricas, "nascidas em berços de ouro e renda", com suas "criadinhas louras" e pajens, passarela das paqueras e flertes da juventude, palco para elegantes quermesses de caridade, parada dos requintados corsos de carnaval, campo de batalha de graciosas batalhas de confete $^{60}$. Um trunfo da "picareta higiênica", que abrira respiros de pureza socioambiental para as elites ${ }^{61}$. Para garantir a ordem, estavam ali as grades, a elevada

\footnotetext{
${ }^{58}$ Para além do oneroso peso dos exacerbados passivos deixados pelas gestões anteriores, o início da prefeitura de Washington Luís coincidira com o início de uma grande retração econômica, proporcionada principalmente pela queda de exportações e empréstimos internacionais com o início da Primeira Guerra. Como estratégia frente a esse cenário, o prefeito adota as severas faces da austeridade. Prioriza as obras centrais em detrimento dos arrabaldes, atrasando não somente a abertura da Praça Buenos Aires, mas também do mirante da Avenida Paulista. PEREIRA, Robson Mendonça. O Prefeito do progresso: modernização da cidade de São Paulo na administração de Washington Luís. Tese (Doutorado) FHDSS-UNESP, 2005, p. 74 -75 e 29-30.

${ }^{59}$ Em seu segundo mandato, Washington Luís não consegue formar maioria na Câmara e acaba entrando em intensos conflitos com os vereadores, dentre os quais alguns chegaram até mesmo a atos extremos, como demitir-se do cargo, o que foi feito por Joaquim Marra, um aliado de Piedade na cruzada pela abertura da Praça Buenos Aires. Para uma análise mais profunda dessa crise política, cf. PEREIRA, 2005, p. 233-267.

${ }^{60}$ Cf. HOMEM, 1980, p. 72-74; Correio Paulistano, "Festa das árvores", 29 set. 1928; Correio Paulistano, "Festa de caridade", 19 fev. 1920; A Gazeta, "A cidade que não tem onde brincar", 23 jun. 1931.

${ }^{61}$ Expressão utilizada por Menotti del Picchia em sua crônica "Paisagem Paulista", publicada em 2 de dezembro de 1926 no Correio Paulistano.
} 
altitude, a prestigiosa e afastada localização, tudo isso protegido sob a égide do portentoso e auspicioso cognome: Buenos Aires (FIG. 81-82).

Mas “os ares impuros” eram voláteis, argutos e industriosos. Como na Avenida, as fronteiras reais eram mais simbólicas do que físicas. Afinal, a proximidade material de palacetes e casebres era inconteste, mesmo que muitos não quisessem vê-la. As grades eram uma advertência, mas não um impedimento. Eram uma tentativa de dar ao público a cara de não público e, quem sabe, afastar dali o tão indesejado público. Para alguns, talvez funcionasse. Mas é certo que tantos outros não se amedrontavam. Sobre as crianças pobres e remediadas, sabemos que por ali circulavam e brincavam, pois como nos conta Maria Cecília Naclério Homem, algumas famílias ricas não permitiam a seus filhos "misturar-se aos meninos que frequentavam a Praça Buenos Aires"62. Entre os adultos, sabemos apenas daqueles que adentravam no âmbito de mais cômoda e conveniente interlocução entre pobres e ricos: o comércio. Ambulantes abasteciam os passeios de adultos e crianças com doces e refrescos ou vendiam de porta em porta, e por ali encontravam repouso para seguir a caminhada. Pouco sabemos sobre como se relacionavam com esse espaço, material e social, para além da deduzível simpatia do bom mercador.

Contudo, certamente havia mais. Um homem misterioso, entrevisto em uma brecha jornalística, deixou-nos um estrondoso enigma, ali no meio da praça. No vinte e oito de fevereiro de 1928, José Heizemberg, um ambulante de apenas vinte e dois anos, deslocara-se de sua casa no Bom Retiro até Higienópolis para, em pleno jardim, meter uma bala contra o próprio ventre ${ }^{63}$. E ele não foi o único. No ano seguinte, foi encontrado no meio da Buenos Aires um homem desacordado, não identificado que, em tentativa de fazer a longa viagem, ali ingerira uma alta porção de lisol. Analogamente, no mesmo dia que José, Maria Rodrigues, de vinte e três anos, saiu para passear com uma amiga e, ao chegar à frente do Teatro Municipal, ingeriu enorme quantidade de ácido fênico, caindo ao solo e contorcendo-se em dores nas escadarias de um dos mais vistosos monumentos das elites. Nesses atos, mil perguntas

\footnotetext{
${ }^{62}$ HOMEM, 1980, p. 153.

${ }^{63}$ A Gazeta, "Vontade de morrer", 28 fev. 1928.
} 
pulsantes, mas insolúveis à nossa limitada visão. Ainda mais tendo em conta que tudo o que sabemos sobre esses jovens trabalhadores provém das breves linhas que os jornais dedicavam às suas tragédias.

Contudo, temos suas cartas e versos, repletos de indícios e sinais de suas lancinantes aflições. Antes que o leitor se engane, não são documentos tradicionais, não foram inscritos em papel e caneta, mas com seus corpos, diretamente na trama do cotidiano. Na esteira das instigantes reflexões de Fernanda Marquetti (2012; 2014), podemos pensar que, contrariando a corrente acepção do autoextermínio como um evento exclusivamente de foro íntimo, o suicídio desses trabalhadores também carregava aspectos públicos ${ }^{64}$. Contudo, a autora não se centra na sua arqueologia psicológica e motivadora do suicida, mas apenas nas escolhas e premeditações que cercam o seu momento final. Seu interesse reside, portanto, em suas implicações comunicativas. Sem minimizar os recônditos emocionais e psíquicos dos suicidas, e sem ignorar a existência de atos impulsivos, ela sugere que, principalmente quando executado em espaços públicos, o evento do autoextermínio é comumente carregado de intenções simbólicas e transgressoras, à maneira de um espetáculo. Suas últimas palavras aos vivos são dirigidas em forma de cena, para a qual são premeditados também um palco e uma plateia ${ }^{65}$.

Sob o prisma de Marquetti, as escolhas de José, Maria e o anônimo são tudo, menos triviais. Eles escolheram cenas, cenários e plateias bastante específicos. Respeitadas as devidas diferenças, vibram em uma cólera semelhante à dos suicídios de cativos ocorridos no Brasil escravista. São muitos os estudos que apontam para a rebeldia e a revolta que embebiam o ato desses indivíduos, transformando as perturbações mentais e emotivas de seus protagonistas em uma das mais potentes e

\footnotetext{
${ }^{64}$ Apesar de a autora centrar sua pesquisa em eventos ocorridos durante as décadas de 1990 e 2000, a distância de nosso recorte temporal não parece ser um problema. Afinal, os elementos analisados por ela carregam tensões familiares às do começo do século: estresse, frustação laboral, conflitos domésticos, etc. MARQUETTI, Fernanda Cristina. O suicídio como espetáculo na metrópole: cenas, cenários e espectadores. São Paulo: Editora Fap-Unifesp, 2011 e MARQUETTI, Fernanda. O suicídio e sua essência transgressora. Psicologia USP, São Paulo, v. 25, n. 3, 2014, p. 237-245.

${ }^{65} \mathrm{Na}$ altura dos eventos aqui analisados, a plateia poderia ser imediata, mas também indireta, pois muitos dos suicidas certamente já detinham certo domínio dos eventos que eram capazes de galgar lugar de destaque na voz da mídia e do povo.
} 
violentas formas de protesto ${ }^{66}$. No caso dos cativos, para além do choque da cena, seu último ato feria materialmente seus senhores, pois significava a perda de uma de suas mais valiosas posses. No universo do trabalho livre, esse tipo de agressão não existia, ao menos para a maioria, que executava trabalhos pouco especializados. Contudo, no espaço da metrópole, ainda mais no interior do contido e dominador habitus das elites, as oportunidades simbólicas se ampliavam.

O suicídio de Maria, por exemplo, foi antecedido por dois dissabores da faina diária. Mesmo que não expliquem o seu ato, talvez sejam significativos de sua última escolha. O primeiro, três dias antes de seu desfecho final, ocorrera na residência em que trabalhava na Rua Augusta, donde saíra por acreditar que a patroa lhe perseguia. Indo morar em outro serviço na Baronesa de Itu, não encontraria maior sossego: rapidamente a relação com a nova empregadora descamba para a animosidade e o conflito. É no mínimo instigante que seu grito final tenha sido aos pés de um lugar talvez estranho a ela, mas certamente habitual às patroas.

No caso de José, o mesmo. Apesar de desconhecermos sua trajetória profissional, é inegável que seu espetáculo fora ainda mais premeditado. Diferentemente do anônimo que se deitara envenenado em um canto e foi encontrado muito tempo depois, desacordado, sem reação, José planejou uma verdadeira irrupção no cotidiano da Praça. Um ato colérico. Não é difícil imaginar sua repercussão. Um disparo repentino. Os olhos voltam-se para a origem do sonido. Crianças param. Bebês choram. Damas se escondem. Cavalheiros correm. Alguns fogem, outros se apressam a socorrer o ferido. Espanto ao descobrir que se tratava de um suicida. Um trabalhador. Um ambulante. O tiro fura e o ventre sangra. Poderia ter escolhido um meio silencioso, limpo. Mas preferiu o estrépito e a impureza. Poderia tê-lo feito em seu bairro. Poderia

\footnotetext{
${ }^{66}$ Um balanço sobre trabalhos que tratam do tema pode ser apreciado em OLIVEIRA, Saulo Veiga e ODA, Ana Maria Galdini Raimundo. O suicídio de escravos em São Paulo nas últimas duas décadas da escravidão. História, Ciências, Saúde - Manguinhos, Rio de Janeiro, v. 15, n. 2, p. 371-388, abr/jun. 2008. Dentre os trabalhos que convergem na percepção do suicídio como um ato de revolta, podemos citar: BASTIDE, Roger. Os suicídios em São Paulo, segundo a cor. Boletim de Sociologia da Universidade de São Paulo, São Paulo, USP, n. 71, p. 1-49, 1943; OLIVEIRA, Saulo Veiga. Suicídios de escravos em Campinas e na província de São Paulo (1870-1888). Dissertação (Mestrado) - Universidade Estadual de Campinas, Campinas, 2007; KARASCH, Mary C. A vida dos escravos no Rio de Janeiro (1805-1850). São Paulo: Companhia das Letras, 2001 e MOURA, Clóvis. Dicionário da escravidão negra no Brasil. São Paulo: Edusp, 2004.
} 
ter sido em sua casa. Poderia ter sido no Centro. Mas ele encontrava o seu significado na Buenos Aires, e nos frequentadores da Buenos Aires. Deitava suas vísceras na ordem de um bairro que se autoclamava Higienópolis. Na praça dos bons ares. Mesmo que não trabalhasse por ali, a mensagem era clara. Era aos habitués da Praça, ou por ela simbolizados, que dedicava o seu desespero. E dos seus valores "civilizados" de polidez, higiene, privacidade e conveniência, escancarava o seu estrondoso desligamento ${ }^{67}$.

Com o suicídio-espetáculo, José rompia as barreiras do público e do privado, penosamente resguardadas pela alta sociedade. Invadia o público com sua miséria, que, ao ver dos convertidos à intimidade burguesa, deveria ter sido bem guardada em um diário, no mais em uma gaveta ${ }^{68}$. Convulsionava o conforto do jardim com sua delinquência. Escancarava sua bruta realidade àqueles que sistematicamente esforçavam-se por ignorar e velar a penúria de sua existência. A escolha da arma e o derramamento de sangue talvez representassem seu repúdio a tudo aquilo que tentavam instituir violentamente aos indivíduos de sua classe: a disciplina, a higiene, a reverência. Mesmo que por um instante ele se fizera notar, e desestabilizara o sonho das elites com o seu assombroso pesadelo. Transformara a praça que a alta sociedade tanto queria como quintal em um espaço público, uma verdadeira arena de manifestação e embate.

No dia ulterior, ou na semana seguinte, talvez tenha caído novamente no esquecimento. Mas momentaneamente o suicídio realmente incomodava. Porém, como era costume da imprensa dos abastados a respeito dos trabalhadores, mesmo um dos mais audaciosos e pavorosos atos da cultura ocidental era retratado sob as impiedosas cores da ironia e do desprezo. As espetaculosas mortes de Maria e José,

\footnotetext{
${ }^{67} \mathrm{Em}$ muitos dos casos analisados por Marquetti, ela observa que os suicidas escancaram seu desligamento da "civilização" através de gestos, singelos, como o tirar dos sapatos, a violência contra um documento de identidade, ou até mesmo atos mais transgressores, como ficar completamente despido, invadir propriedades privadas, etc. A seu ver, principalmente nos casos mais extraordinários, tal desligamento faz parte do espetáculo e porta uma potente mensagem crítica às normas que procuram ferir. MARQUETTI, 2014.

${ }^{68}$ CORBIN, 1992 e GAY, 2002.
} 
junto às cenas de outros infelizes, foram introduzidas n'A Gazeta pelos seguintes comentários:

Desgostos íntimos, amores contrariados, maus negócios, moléstia incurável, tédio...

Essas as chapas corriqueiras que a crônica policial dos jornais gasta para justificar os grandes gestos de desespero dos cansados da vida.

E não há de fugir a elas, porquanto, quando a epidemia dos suicídios começa a grassar na cidade não sobra aos tresloucados tempo para escrever cartas explicativas dos seus desvairamentos...

Qualquer contratempo ou contrariedade de certos espíritos fracos servem para justificar atos de loucura. Gente há que apenas aguarda um pretexto para empreender a grande viagem, na certeza de que esse pretexto será levado na devida conta pela sociedade...

Ontem tivemos um punhado de tentativas de suicídio e todas elas sob os mais fúteis pretextos... ${ }^{69}$

Chega a ser obsceno. Ainda mais se comparado às condolentes e longas matérias que tratavam dos casos de suicídio na alta sociedade. Aos seus abatidos era concedido o privilégio do compadecimento e da compreensão. Eram doentes, infelizes, mas nunca obtusos ou idiotas. Não foi diferente com o espantoso caso de Moacyr Toledo Piza, que levou junto de si, em plena Avenida Angélica, uma das mais célebres cortesãs da cidade: Nenê Romano. Nascida Romilda Machiaveri, filha de imigrantes italianos, Nenê crescera em um lar humilde, trabalhando desde a infância como costureira no Brás. Dada sua beleza exorbitante, galgara a alta sociedade através de entrevistas amorosas, que concedia, a princípio, nas “pensões alegres" da cidade. Ao passo que sua clientela se tornava mais exclusiva e mais sigilosa, ela passou a recebê-los em casas por ela mesma alugadas. Dizem que sua freguesia era tão próspera que chegava até aos mais altos escalões do perrepismo paulista, abarcando corpos e corações de senadores e ex-presidentes, como Rodrigues Alves, de deputados, como Rodolfo Mirado, e até mesmo do então Presidente do Estado de São Paulo, Washigton Luís ${ }^{70}$.

\footnotetext{
${ }^{69}$ No mesmo dia, Ignez de Moura, que estava internada na Santa Casa, ingerira veneno, tentando pôr termo à própria vida. Eugenio Bardasenko, em sua própria residência, tentara meter uma bala na própria cabeça. O mesmo fizeram João Soares e Raul Moglieri, que tentaram a longa viagem através do amargo gosto do iodo. A Gazeta, "Vontade de Morrer", 28 fev. 1928.

${ }_{70}$ FAUSTO, Boris. Uma paixão de outrora. Revista Piauí, edição 70, jul. 2012. Disponível em: http://piaui.folha.uol.com.br/materia/uma-paixao-de-outrora/ (último acesso em fevereiro de 2017).
} 
Nenê e Moacyr, contudo, se aproximaram de maneira insólita. O jovem escritor, formado pela Faculdade de Direito, membro de uma tradicional e portentosa família da cidade, fora contratado pela cortesã para defendê-la em uma ação de reparação de danos contra uma das filhas de abastados fazendeiros de Ribeirão Preto, Maria Eugenia Junqueira. A ação não era trivial, pois resultava do ataque a navalhas que anos antes três homens haviam proferido contra Nenê a mando da jovem enciumada. Rasgando-lhe a cara, visavam acabar com sua carreira. Contudo, os ferimentos não foram graves e Nenê seguia aventurando-se na high society. Cliente e advogado rapidamente converteram-se em amantes. O caso durou dois anos, até que Nenê colocou fim ao romance. Moacyr, por sua vez, não se conformava com aquele desfecho. Insistente, passou a perturbar Nenê com presentes e visitas inusitadas. À beira de seu tormento, escreveu os tenebrosos versos, que hoje parecem proféticos:

Que hediondo crime, que mortal pecado

Cometi, que me tens por inimigo?

Por que o bem de olvidá-la não consigo?

Eu que, do seu amor ando olvidado

Por quê? Bem sinto: é que nos céus, sereno

Só podes compreender o amor divino,

Nunca, nunca provaste o amor terreno

O amor de uma mulher que é o meu Destino

E cuja boca é a taça de veneno

Que faz de um homem justo - um assassino! $!^{71}$

Foi no dia vinte e cinco de outubro de 1923. Era noite e Nenê chamara um carro para buscá-la em casa. Moacyr, que rondava obsessivamente sua residência, apareceu de repente. Obstinado em ter-lhe uma conversa séria, insiste para que a moça entre em seu carro. Os dois vão no banco de trás. Enquanto o motorista tocava a máquina sem destino, os dois palestravam. Rondaram pelo Centro, subiram a São João e, ao

\footnotetext{
${ }^{71}$ Apud FAUSTO, 2012.
} 
chegarem no meio da Angélica, pouco acima da Praça Buenos Aires, o motorista escutou três estampidos consecutivos. Eram os tiros que tiravam a vida de Nenê. Ao parar o carro, o chauffeur viu Moacyr tornar a arma contra si mesmo e descarregar a fogo o seu tempestuoso tormento ${ }^{72}$.

No dia seguinte, a maioria dos jornais da cidade não reservou sequer uma linha ao caso $^{73}$. Provavelmente em complacência à família de Moacyr, que não queria ver o rosto de sua proeminente prole estampado ao lado da meretriz. A não ser o Combate, que se vangloriava de ser incorruptível e ter uma linha editorial investigativa especialmente sensacionalista ${ }^{74}$. Com sua implacável verve moralista, o jornal decidira abrir a "Paixão Fatal” com as seguintes linhas em epitáfio ao tombado Toledo Piza:

Matou-se Moacyr Piza, o brilhante, o audaz, o valoroso escritor que toda São Paulo admirava. Matou-se depois de ter matado Nenê Romano, a mulher fatal, que tinha um rosto de anjo e uma alma de perversa (...).

Moacyr foi um forte na sua profissão, na sua batalha de todos os dias, nas batalhas da política, e pela sua afirmação no campo da arte e da advocacia, foi fraco demais na luta extenuante e trágica pela e contra a sua paixão.

Nenê Romano, flor da rua e da lama, mulher do povo e contra o povo, que possuía o sorriso que acendia os mais perigosos fogos da paixão torturante $\mathrm{e}$ louca; o mais completo símbolo da leviandade e da perversidade conseguiu, com a sugestão da mulher que faz sofrer e ri, armar o braço de Moacyr Piza e desafiar a morte. E a morte venceu!...

Aos nossos olhos, a inversão criminosa é estarrecedora. Porém, eram os tempos de domínio pleno dos homens das instituições de ordem e justiça. Tempos em que a passionalidade figurava, impassível, como justa causa ao feminicídio ${ }^{75}$. A ligação do desenlace final com a Avenida Angélica parece contingente, mas a relação entre a elite masculina e a prostituição explicitada pelo caso, como já vimos, era arraigada (FIG. 83-84).

\footnotetext{
${ }^{72}$ O Combate, 26 out. 1923.

${ }^{73}$ Refiro-me aqui aos diários que circulavam entre os mais abastados, como O Estado, O Correio Paulistano e A Gazeta.

${ }^{74}$ Cf. BALSANOBRE, Sabrina Garcia. A História de São Paulo no ano de 1918 pelo olhar do jornalismo militante: uma análise dos gêneros textuais de O Combate. In.: Anais do VI Siget (Simpósio Internacional de Estudos de Gêneros Textuais), 2012 e FERREIRA, Pedro Beresin Schleder. Disputas na representação de um "bairro aristocrático". XIV Seminário de História da Cidade e do Urbanismo. Anais, IAU-USP, São Carlos, 2016. Disponível em: http://www.iau.usp.br/shcu2016/anais/wp-content/uploads/pdfs/58.pdf (último acesso em fevereiro de 2017).

${ }^{75}$ CHALHOUB, 2008, p. 177-203.
} 
Fora do lar, jovens, e os não tão jovens, perambulavam por entre as ruas e as “pensões alegres” em busca de divertimento com as cortesãs que se espalhavam pela cidade. As elites obviamente buscavam o prazer em lugares exclusivos, muitas vezes entranhados no próprio seio de seus tão queridos bairros. A aparente contradição, contudo, era um modus operandi intrínseco ao habitus masculino. Representação e intimidade tornavam-se cada vez mais dissociadas. Não eram poucos os que ostentavam ao mundo o mais rígido puritanismo e a devoção à vida familiar, mas na vida privada chafurdavam-se na gandaia e prazeres das meretrizes ${ }^{76}$. A hipocrisia era um traço marcante dessa cultura que, ao aparentemente repreender rigidamente todos quanto à exploração da libido, distribuía desigualmente as penas para os que infringiam a regra. As escapadas masculinas, assim, eram largamente toleradas. Contudo, dentre os homens feitos, eram mantidas em segredo tumular. Uma tarefa difícil para o historiador lidar com esse interdito, pois, ainda mais ao se analisar jornais, são praticamente ausentes as menções aos temas escondidos.

Mas mesmo nesse ambiente tão controlado havia frestas por onde podemos espiar alguns dos seus segredos. Em 1918, um caso difundiu nas rodas de mexerico, mesmo que momentaneamente, a má fama de Higienópolis como um lugar de pecaminosa luxúria. Trata-se do caso intitulado "Um maurício milionário", largamente divulgado pelo Combate, no qual se acusava o comendador Antonio Augusto de Almeida Cardia de organizar em seu próprio domicílio, na Avenida Higienópolis, um antro de cafetinagem. Após um ano de investigações oficiais, o comendador foi absolvido, talvez por justiça, talvez por abafo. Mas isso não impediu que as más línguas espalhassem o seu veneno. Assim, nos relatam os próprios redatores que:

A divulgação das notícias referentes a este escândalo veio criar uma situação desagradabilíssima para pessoas que nada têm a ver diretamente com o caso. (...) De muitas senhoritas sabemos que não se animam a tomar o bonde da linha 'Hygienopolis'. É que não querem ouvir graçolas inconvenientes, que

\footnotetext{
${ }^{76}$ Cf. FONSECA, Guido. História da Prostituição em São Paulo. São Paulo: Resenha Universitária, 1982; RAGO, Margareth. Os prazeres da noite: prostituição e códigos da sexualidade feminina em São Paulo, 1890-1930. Rio de Janeiro: Ed. Paz e Terra, 2008.
} 
lhes são dirigidas durante o trajeto. E que diremos, então, das que residem na própria avenida? ${ }^{77}$

Os desejos sexuais, como é de se imaginar, não conheciam fronteiras de classe. Aos pobres aventureiros, restavam as pequenas casas do Centro, ou as próprias ruas e praças do bairro. Lembremo-nos dos moradores da Praça Buenos Aires que protestavam contra a falta de iluminação e policiamento naquele local, que permitia que o jardim fosse tomado todas as noites por toda a sorte de "entrevistas amorosas"78. Se predominavam casais ou prostitutas, não há como saber. Muito menos se eram dominantes os pobres ou os remediados.

Fato é que nesse evento reitera-se, sob uma nova forma, uma das considerações mais importantes de nossa passagem pela Angélica até aqui: apesar de aparentemente robustos e implacáveis, os aparatos de controle e ordem das fronteiras socioespaciais pelo Estado e pelas elites eram repletos de frestas e fissuras. Nesses interstícios, nessas penumbras, se estreitavam e agiam os setores médios e trabalhadores. Não só na Buenos Aires por vezes apagavam-se as luzes, abrindo oportunos campos de ação aos menos apossados: como vimos, o mesmo ocorria no imprevisível e descontrolado mercado de terras e imóveis, que acompanhava as oscilantes ondas da economia nacional; nas idiossincrasias da localização urbana, que poderia acumular em um mesmo espaço fatores de enaltecimento e desvalorização; no tumultuado universo dos interesses e dos desejos, que por vezes colocavam em conflito membros da elite, com resultados por vezes inesperadamente valiosos para os de baixo; nas repentinas e localizadas despressurizações dos interesses na Câmara Municipal, fosse por uma estratégia de manutenção do poder ou por momentâneos arroubos de virtude; na volúvel e incontrolável representação do "aristocrático", passível de ser apropriada para as mais diversas finalidades; e, por fim, nas inusitadas complementações entre diferentes modos de vida, que aproximavam e alinhavam os extremos sociais na vida prática.

\footnotetext{
${ }^{77}$ O Combate, "Um Maurício Milionário”, 13 de agosto de 1918.

${ }^{78}$ A Gazeta, "Praça Buenos Aires”, 19 set. 1924.
} 
*** 

Todos os conceitos em que, do ponto de vista semiótico, se congregue todo um processo, esquivam-se à definição: só o que não tem história é definível.

Nietzsche

Uma coisa de cada vez Tudo ao mesmo tempo agora

Arnaldo Antunes 

Considerações Finais 

Recordo-me vagamente de uma conversa. Não me lembro do dia, da ocasião, nem de quem falava. Não recordo o que eu fazia, nem se lia ou escutava. Mas tenho certeza de que naquela manhã, tarde ou noite, começou em meu íntimo uma lenta e silenciosa revolução. Um mundo desabava e outro se anunciava, um giro colossal, que só mais tarde compreenderia. Nesse dia me parecia que o mestre deslembrado, meio distraído, me fazia uma proposta como se me oferecesse experimentar uma nova marca de chicletes : "já reparou como sempre estamos a refletir sobre se uma pessoa é isso OU aquilo, se uma coisa é isso $\mathrm{OU}$ aquilo, se um evento foi isso $\mathrm{OU}$ aquilo... e se pudéssemos assumir que as coisas no mundo são, foram e podem vir a ser isso $\mathrm{E}$ aquilo ao mesmo tempo, não parece mais lógico?”. Lógico, no sentido tradicional, certamente não era. Muito pelo contrário, o que dizia era um absurdo, pois jogava às favas um dos axiomas centrais do que até então eu aprendera como o pensamento racional: o principio de não contradição. Assim como dois objetos não podem ocupar o mesmo espaço, uma proposição não pode ser verdadeira e falsa ao mesmo tempo. E pronto.

Esse princípio de não contradição eu nunca aprendera formalmente, mas fora educado dentro de seus preceitos, na vida familiar, na faculdade e na escola. Até então, só sabia pensar e explicar o mundo a partir de suas diretrizes. Os indivíduos são egoístas ou bondosos, um bairro é rico ou pobre, a história de São Paulo, uma epopeia ou uma tragédia. Estava preso nesse impiedoso mundo preto e branco das dicotomias disjuntivas, e sem saber, sofria pela falta da escala de cinzas. Por isso, o disparate não 
me soara esquisito, estúpido ou entediante. Pelo contrário, em seu rumor, pude perceber, distante, uma paisagem dissonante, mas estranhamente atraente e agradável.

Certamente não escapou ao leitor que foi justamente na convivência imbricada dos contraditórios proposta pelo E que encontrei o meu caminho explicativo para o "fazer-se" da cidade. Só assim pude suspender o anseio de resumir sua modernização a isso ou aquilo, ao domínio desse ou daquele, ao protagonismo de uma esfera ou de outra, e acessar novos problemas e desafios. Como explicar a modernização de uma cidade em que são ativos ricos, médios $\mathrm{E}$ pobres, na qual as dinâmicas de materialização, regulamentação e planejamento são conformadas pelos anseios e empenhos destes $\mathrm{E}$ daqueles $\mathrm{E}$ ainda daqueles outros mais agentes? Como explicar uma Avenida que era ao mesmo tempo passarela E trampolim E palco central da vida dos trabalhadores? Como dar conta de tantacoisajuntaaomesmotempo?

Não foi à toa que, ao invés de lineares, concisas e monolíticas, as trajetórias simbólicas, sociais e materiais da Avenida encontraram sua melhor expressão nas noções de ambivalência, trama, conflito, disputa, negociação, dispersão e justaposição. Todo um vocabulário fundado pelos princípios de pluralidade e interação e com base instável, pois sempre sujeito aos movimentos das circunstâncias. Noções que me permitiram manter vivos ao longo do texto os caminhos, significados e práticas contrários e díspares dos agentes, sem a necessidade de conciliação ou síntese.

Longe de um processo unitário, regido por um único grupo dominante e rompido apenas em momentos de exceção, descrevi o "fazer-se" da cidade como um agenciamento constante de conflitos. Um resumo conciso, porém não imóvel, e que tem de ser tomado em seu sentido multidimensional e multifacetado. Primeiramente porque os conflitos não eram organizados em pares duais, uma luta desse contra aquele, pelo desejo disso ou daquilo, mas em ramos tentaculares. Todos - as elites, o Estado, os setores médios, os trabalhadores e os agentes imobiliários - foram igualmente ativos no "fazer-se". A distribuição de poderes e meios era desigual, o que resultava em vantagens aos mais abastados e obstáculos aos menos favorecidos, mas não chegou nem perto de garantir a uns a onipotência e sujeitar os outros ao interdito. E se Deus existe, ele não vivia na Terra. Nem dentro dos grupos e das classes sociais. 
Nestes, concomitante ao partilhado habitus e às atitudes associativas, havia a heterogeneidade de ideias e interesses, públicos e privados, que, longe de serem constantes e estáveis, muitas vezes eram indiferentes uns aos outros, ou colidiam por sua disparidade. Daí uma das potências da teoria de Bourdieu sobre o habitus e, depois, sobre as disputas internas nos campos e nas classes - os grupos sociais eram homogêneos E heterogêneos, fraternos E competitivos, tudodeumasóvez.

Para tanto me foi valioso o aprimoramento do olhar circunstancial e utilizar com critério o conhecimento a priori, pois a organização dos tabuleiros da cidade era extremamente dinâmica. Não foram poucas as ocasiões em que encontrei peças ocupando posições e tomando lados que, ao que até então havia sido estabelecido pela historiografia, pareciam improváveis ou até mesmo impossíveis.

Segundo ponto: seus encontros e desencontros, convergências e dispersões, não se resumiam a uma única esfera da vida urbana. O "fazer-se" da cidade deu-se no entrecruzamento de conflitos e negociações travados em âmbitos simbólicos e representacionais, econômicos e materiais e no chão cotidiano dos modos de vida e das relações sociais. Da mesma forma que os agentes, esses âmbitos não eram hierarquizados, mas articulados, entrecruzados e entrelaçados. A trama de tensões conformadas pelos agentes, portanto, era multidimensional.

Para consolidar essa imagem, procuramos resumir o "fazer-se" da cidade como o agenciamento de tensões multidimensionais e plurifacetadas. Recuperemos alguns de nossos argumentos. Começamos nossa trajetória pelo teso campo de forças em que era disputada a regulamentação e a comercialização de terras e imóveis da Avenida. Concorrências travadas no âmbito concreto da via e na Câmara Municipal, principalmente em torno da famigerada lei de recuos. Por um lado, incidiam os proprietários expeditos que desejavam a Avenida como um espaço heterogêneo, de retorno comercial simples e ágil. $\mathrm{Na}$ ponta oposta, os que idealizavam um mercado exclusivo, de retorno lento, mas com lucro ampliado. Por outra via, os agentes municipais que almejavam tornar a Angélica um cartão-postal com potência simbólica para cooperar na consolidação de posições políticas e econômicas em esferas de âmbito nacional e internacional. Por um flanco inusitado, o prefeito Antônio da Silva 
Prado, que apesar ter sido um dos maiores entusiastas de projetos embelezadores, naquele em específico enxergava entraves aos seus interesses privados materiais e simbólicos. E acompanhando o prefeito, porém por uma vereda própria, José Oswald, que diferentemente de Cardim e Telles, parecia desconfiar da viabilidade e dos benefícios do projeto exclusivista para a municipalidade. Isso sem falar dos atores que zanzaram de um lado a outro, como Nothmann e Burchard, que nos primeiros anos da Avenida participaram ativamente na conformação dos baixos preços de seu topo, promovendo uma ocupação de "casas operárias" que logo em seguida tentaram avidamente evitar. Assim como os camaristas que variaram de opinião e posição ao longo dos quase dez anos de embate que circundaram a regulamentação dos afastamentos.

A disputa foi larga e resultou em glórias e derrotas para todos os lados. Não à toa, concretizada sob a tesa trama desse cabo de guerra, a paulatina ocupação material, simbólica e social da Avenida foi irregular e descontínua, alternada por espaços que gozavam de relativa homogeneidade e outros, de manifesta incongruência. Espacialidades que procuramos apreender a partir da rua e da casa, dois âmbitos congênitos e correlacionados nos habitus que conformaram as apropriações da Avenida pelos membros de cada classe. Ali, as elites projetaram o seu recanto bucólico dos nervosos agitos da metrópole, ninho de agridoce conforto para homens e mulheres. Ao mesmo tempo, pensaram suas casas como verdadeiros monumentos, ao passo que concebiam a rua como uma galeria aberta à sua admiração, palco dos ritos de exibição-visão instituídos em seus relacionamentos. Os remediados, com um habitus semelhante, porém baseado em condições e posições sociais menos estáveis e privilegiadas, apropriavam-se dos signos e práticas das elites para suas próprias finalidades, fosse para forjar magnitude em suas casas geminadas, garantir uma boa imagem profissional ou tentar estabelecer uma clientela exclusiva. Os trabalhadores, por sua vez, deram significados diferentes para rua e casa, traçando fronteiras entre elas muito mais porosas do que as dos outros, agitando a passarela-trampolim com suas práticas sexuais, de lazer e sociabilidade que as outras classes costumavam realizar 
entre paredes, fosse em casa, fosse nos espaços semipúblicos dos clubes, hotéis, teatros e cabarés.

Múltipla, a Avenida era conformada por um mosaico de fronteiras: sociais, materiais e simbólicas. Longe de configurarem "muros", eram limiares dinâmicos, de consistência variada. Quando porosas, configuravam espaços de associação e negociação. As casas operárias serviam para que os setores médios viabilizassem seu meio de vida. Criados e artesãos que adentravam a redoma de exclusividade das elites eram ambiguamente bem recebidos por darem sustento ao suntuoso modo de vida dos palacetes. O exercício profissional dos medianos em uma área exclusiva ajudava a viabilizar a reclusão feminina ansiada pelo habitus dos abastados. Os comerciantes, ambulantes e fixos, que se instalavam nas casas pequenas que atrapalhavam a atmosfera suntuosa da passarela das elites, eram os responsáveis por abastecer os seus lares.

Porém, quando cerradas, as fronteiras tornavam-se limiares de rijos conflitos, disputas e tensões. Explodiam em atos de agressão, segregação e violência. A ação majoritária da municipalidade era voraz, contudo, tinha aparência límpida: negligenciava-se por anos a instalação de infraestrutura aos menos providos, promulgavam-se leis de ocupação que inviabilizavam o modo de vida dos trabalhadores, bem como se promoviam, junto a outras instituições e grupos, discursos que os deslegitimavam. A ação excludente das elites era sofisticada: violências simbólicas do dia a dia, elevação de grades, tentativa de exclusão do indesejado pelo controle de preços no mercado de terras e imóveis, uso dos aparatos repressivos e punitivos institucionalizados. Os medianos recorriam à esquiva e ao ardil: com a maquiagem simbólica de suas materialidades e comportamento, aproximavam-se astuciosamente do que os queria afastar e distanciavam-se dos de baixo. Da mesma forma, apropriavam-se sorrateiramente do ideário “aristocrático”, que a princípio os excluía, e o mobilizavam para suas finalidades próprias de representação social e profissional. A violência dos trabalhadores, por fim, era escancarada: atos de rebeldia como roubos e furtos, a apropriação veemente e estrondosa do espaço da rua, culminando em atos extremos, como os espetaculares 
suicídios da Praça Buenos Aires. Mas não raro também recorriam aos meios legais e institucionalizados, como à Câmara Municipal e à mídia, forçando com argumentos, representações e palavras a porosidade de fronteiras que outros persistiam em conservar opacas.

Pelos bondes, vimos que as fronteiras e ambivalências também se manifestavam na experiência da cidade e nas expectativas perante a modernização. A vida moderna era vivenciada de maneira contradita. As invenções do conforto que apaziguavam eram elas próprias imperativos ao cotidiano que proporcionava grande parte do sofrimento. Os mesmos agentes que eram produto e produtores da metrópole eram os que mais ansiavam por viver longe dela. Os bondes encurtavam as distâncias, mas seu dinamismo cobrava o preço em acidentes e vidas. A internacionalização do mercado proporcionava fartas oportunidades para alguns, mas limitava e arruinava os planos de tantos outros.

E mesmo que aparentassem confiar plenamente na harmonia pacífica prometida pela utopia positivista, as elites também viviam a modernização da cidade na ambivalência de júbilo, maravilhamento, temor e horror. Com seus bairros e bondes exclusivos, queriam destilar a modernidade, com se fosse possível purificá-la de suas agruras, mas as tramas cotidianas persistiam em confirmar que as raízes que uniam a pobreza à riqueza, a violência ao conforto, a "modernidade" ao “atraso" eram praticamente congênitas. A idealização de um bairro pacífico para as elites não encontrava respaldo sequer em seus próprios desejos cotidianos, esses também ambivalentes. Afinal, os homens, ao mesmo tempo em que presavam pelo silêncio e o conforto do lar, cobiçavam a bagunça das pensões, ou melhor dizer, no caso, das “mansões alegres" que, por também quererem luxuosas, discretas e exclusivas, as constituam no seio de seus privilegiados bairros. Se pensarmos bem, a vida cortesã dos palacetes também era extremamente contradita, afinal demandava a convivência próxima e cotidiana com os seus contrários, preenchiam justamente o espaço que projetavam como o ápice da distensão com as tensões e conflitos advindos dos múltiplos atritos que se desenrolavam com seus criados. 
Mas essa vivência ambígua não impediu que utilizassem largamente a representação unívoca, pacífica e harmoniosa da modernização para defender seus interesses no "fazer-se" da cidade. Foi o que vimos no debate entre Oswald e Telles acerca dos rumos da Avenida Angélica. Enquanto o primeiro apontava para uma ocupação fragmentária, promovida por grupos e interesses díspares e por uma localidade com qualidades contraditórias, o outro a representava como um espaço homogêneo em todos os aspectos, projetando o seu "fazer-se" pleno e exclusivo, como o resultado necessário de uma equação social. Da mesma forma fez Alcântara Machado anos depois, quando evocou o pleno sucesso da lei de recuos em transformar a Angélica em uma das mais belas e elegantes vias da cidade.

Com minhas explicações do "fazer-se" da cidade, sem dúvidas almejei contribuir para o enriquecimento dos debates da arena acadêmica, fortalecendo leituras já apontadas por outros autores e, espero eu, trazendo também novos elementos e dimensões para a discussão. Mas sem dúvida, junto a esses que me deram amparo e impulso, fui movido por minha intrínseca filiação ao presente. Em âmbito estrito, tive a ambição de dar corpo a uma leitura do "fazer-se" da cidade e, sobretudo, do viver em sociedade capaz de suscitar novas ações nos agentes do presente. Um mapa pelo qual possam ser imaginadas outras estratégias para gerenciar os interesses públicos e privados no planejamento urbano, outras políticas de memória e patrimônio, outras formas e dimensões para compor a arquitetura doméstica. Mas todas, contudo, pautadas por um mesmo princípio, esse mais amplo: o reconhecimento do outro como um agente de relação possível. Seja de negociação, debate ou de conflito. Um aliado, um estranho ou um opositor, mas jamais um inimigo. Que lutemos como adversários, mas não nos deixemos seduzir pelo jogo perverso dos inquisidores.

A alma da democracia é o agenciamento dos contrários. E trepido ao vê-la vacilar. Daí minha insistência na tensa coexistência dos Es, no dinamismo das fronteiras, nas ambivalências de indivíduos, das instituições, das classes e dos grupos. Infelizmente, vivemos em tempos extremos, no qual certas formas de ser, fazer e pensar, mesmo que nunca tenham sido ausentes, voltam a predominar. Tempos em que os muros tornam a se erguer, as certezas absolutas voltam a cegar e as perspectivas enrijecidas do mundo 
e dos processos sociais tendem cada vez mais a separar e segregar. Em meu modesto âmbito, proponho uma resistência de pensamento e de visão de mundo. Uma linguagem para suturar e manter firme esse edifício que pende ao destino desastroso de Babel.

Não importa se dentro de casa, dentro de si, em uma escola, em uma cidade, em um país ou em todo o mundo. Em todos esses universos, o que igualmente me aterroriza é a volta da crença disjuntiva e aniquiladora do isto OU aquilo. O desejo de um mundo liso, unívoco, monolítico e unidimensional. Na prática não será factível. Mas o que verdadeiramente amedronta não é sua consumação, mas do que são capazes os seres humanos e as instituições enquanto acreditam nisso. 
* * * 

Caderno de Imagens 


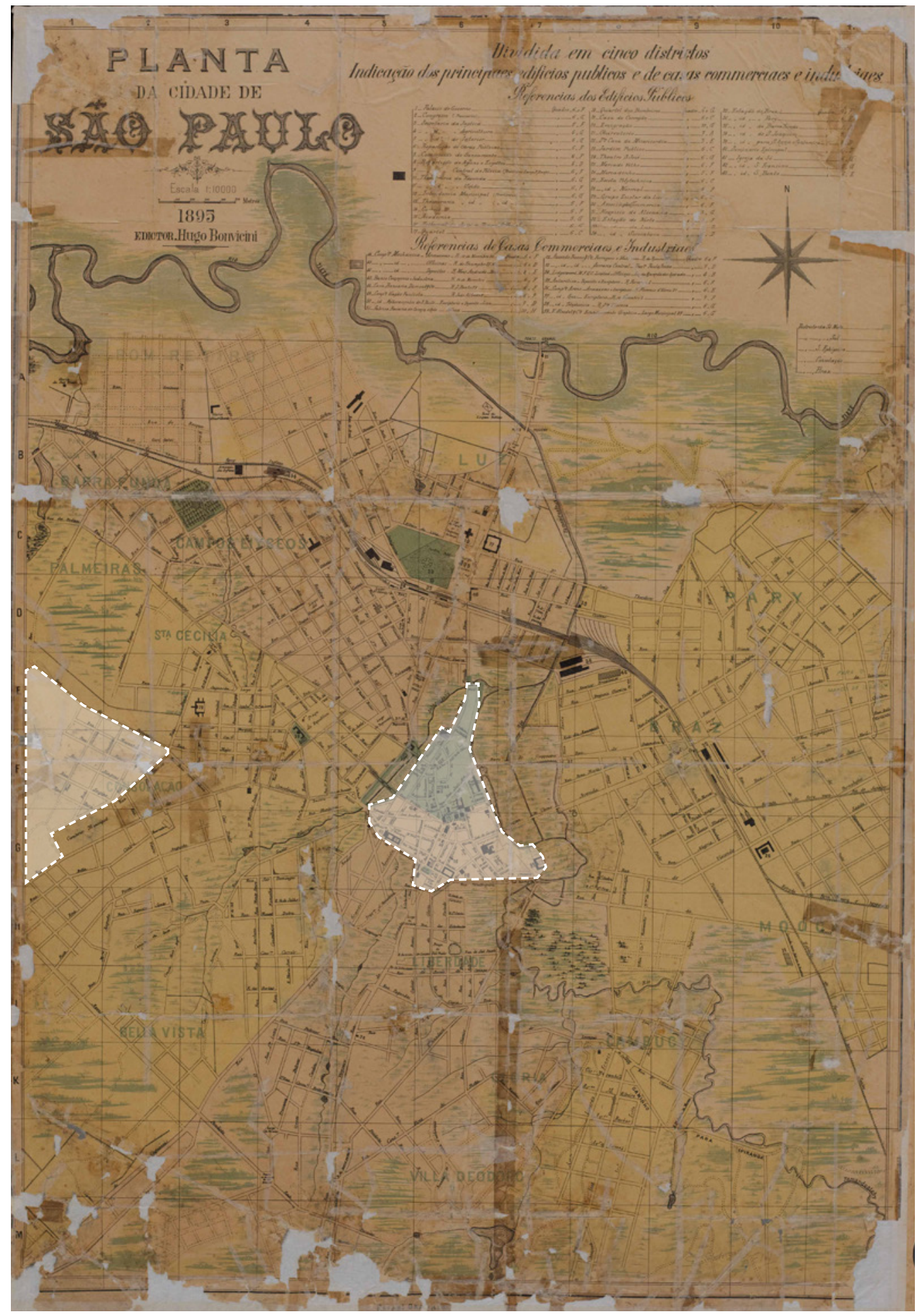

FIG. 1 - Planta da Cidade de São Paulo editada por Hugo Bonvicini, 1895. Nessa imagem podemos observar a distância entre o recém-loteado Boulevard Burchard e o Centro da cidade. Fonte: Repositório Digital do Arquivo Público do Estado de São Paulo. 


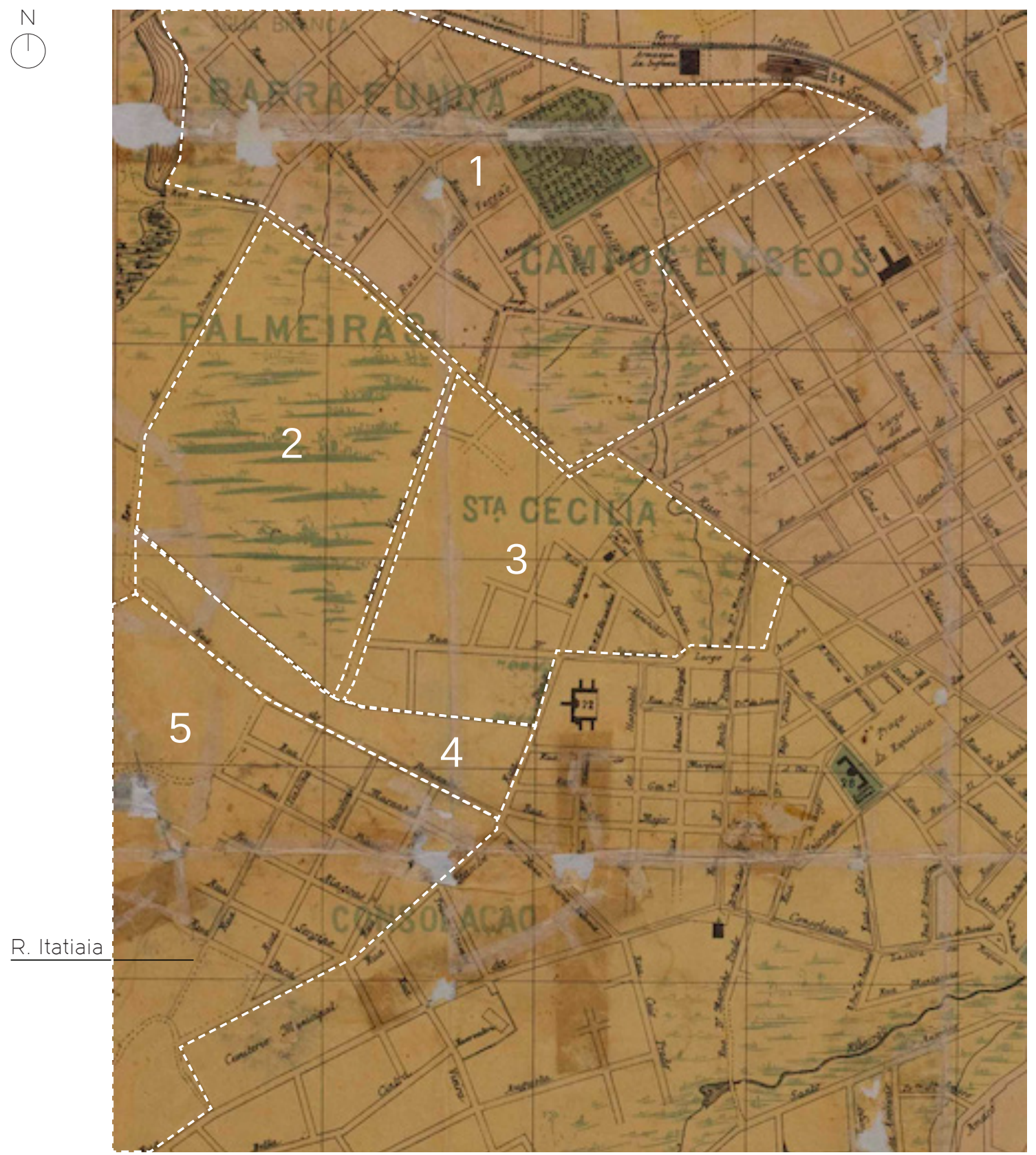

FIG. 2 - Recorte da Planta da Cidade de São Paulo editada por Hugo Bonvicini, 1895. Essa imagem possui muitas camadas importantes de leitura. Primeiramente, nela estão sinalizadas as terras dos cincos maiores proprietários das redondezas da Itatiaia: (1) Antônio da Silva Prado; (2) Maria Angélica de Sousa Queiroz Aguiar de Barros; (3) Domingos José Nogueira Jaguaribe; (4) Veridiana da Silva Prado; e (5) Victor Nothmann e Martinho Burchard.

Na parte superior da Rua Itatiaia, podemos observar sua projeção em linha curva, sinalizando a hesitação dos loteadores quanto ao seu rumo. Em sua parte inferior, podemos observar a via chamada "Vianna Barros", anseio de Maria Angélica de Sousa Queiroz Aguiar de Barros por traçar uma via ligando suas terras ao novo loteamento. Fonte: Repositório Digital do Arquivo Público do Estado de São Paulo. 


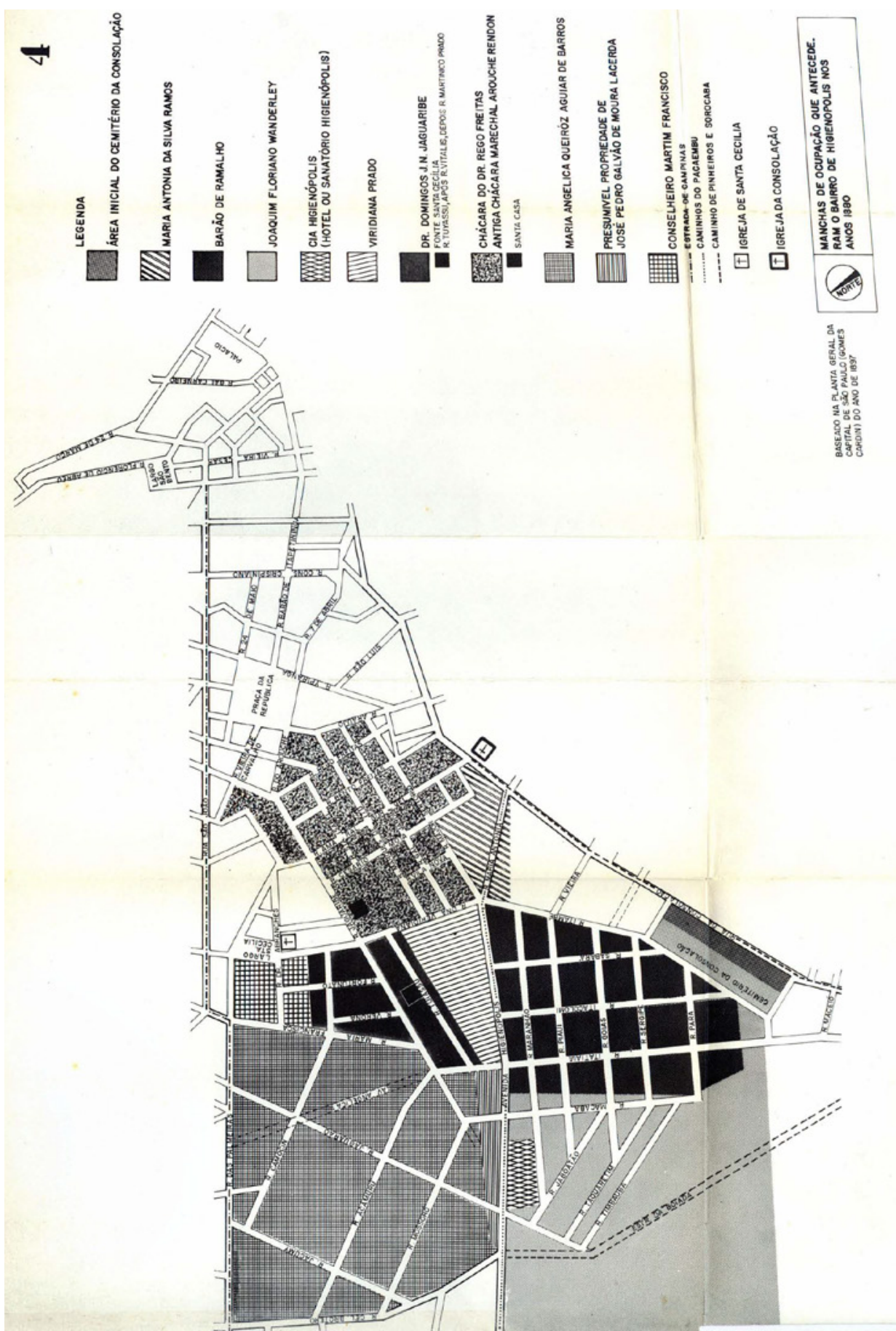

$N \in$

FIG. 3 - Nesse mapa elaborado por Homem (1980), com base no mapa de Cardim (1897), podemos observar as duas chácaras que compuseram prioritariamente as terras do Boulevard Burchard. Em preto estão as terras do Barão de Ramalho, por onde tem início o loteamento, e em cinza, as de Joaquim Floriano Wanderley, que começarão a ser arruadas apenas em 1914. Isso significa que, durante ao menos vinte anos, a Itatiaia foi um dos extremos urbanos da cidade. Fonte: HOMEM, 1980, p. 57. 


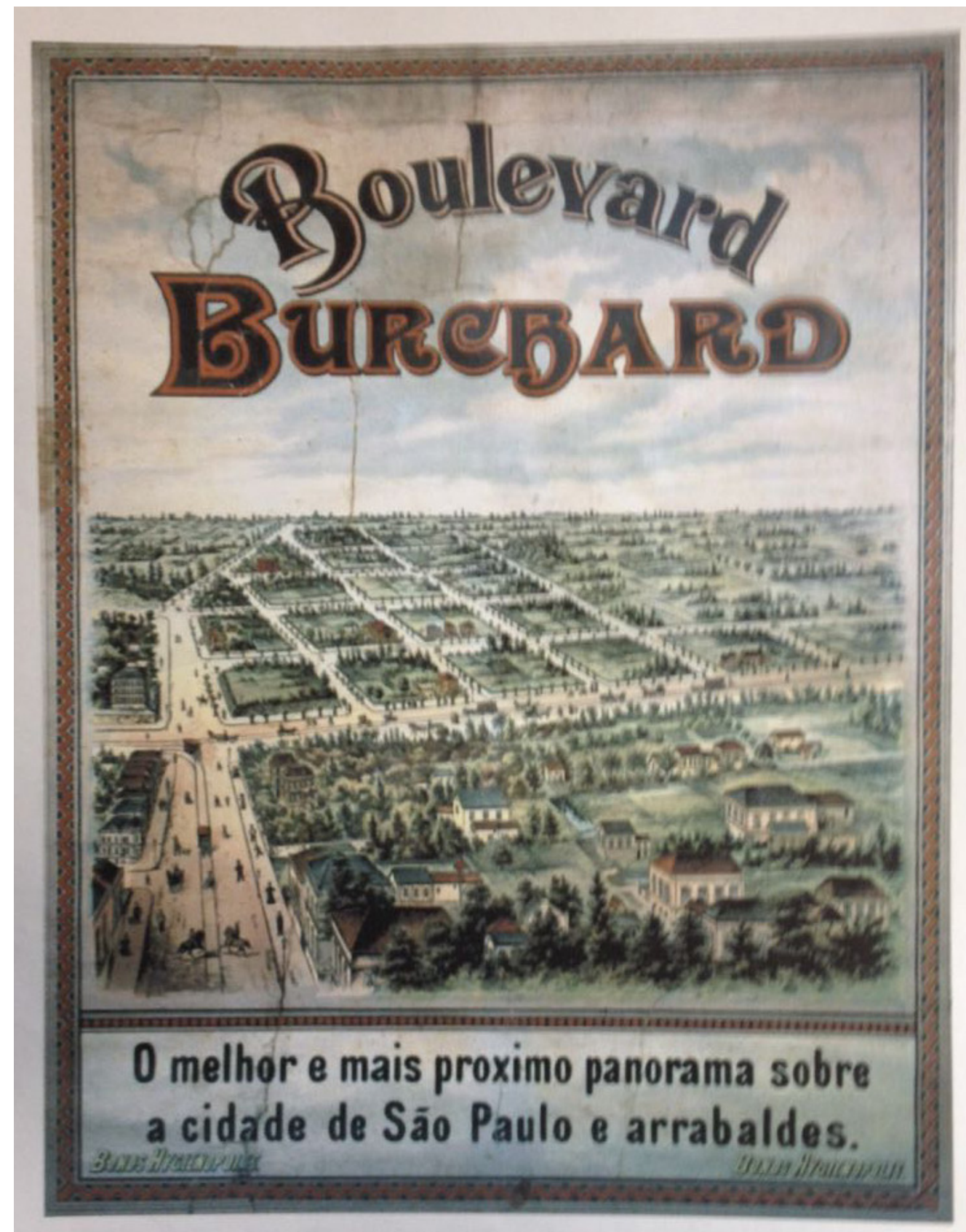

FIG. 4 - Cartaz "Cia de Bonds Hygienopolis", provavelmente veiculado antes de 1896. Fonte: BRITO, 2000, p. 129. 


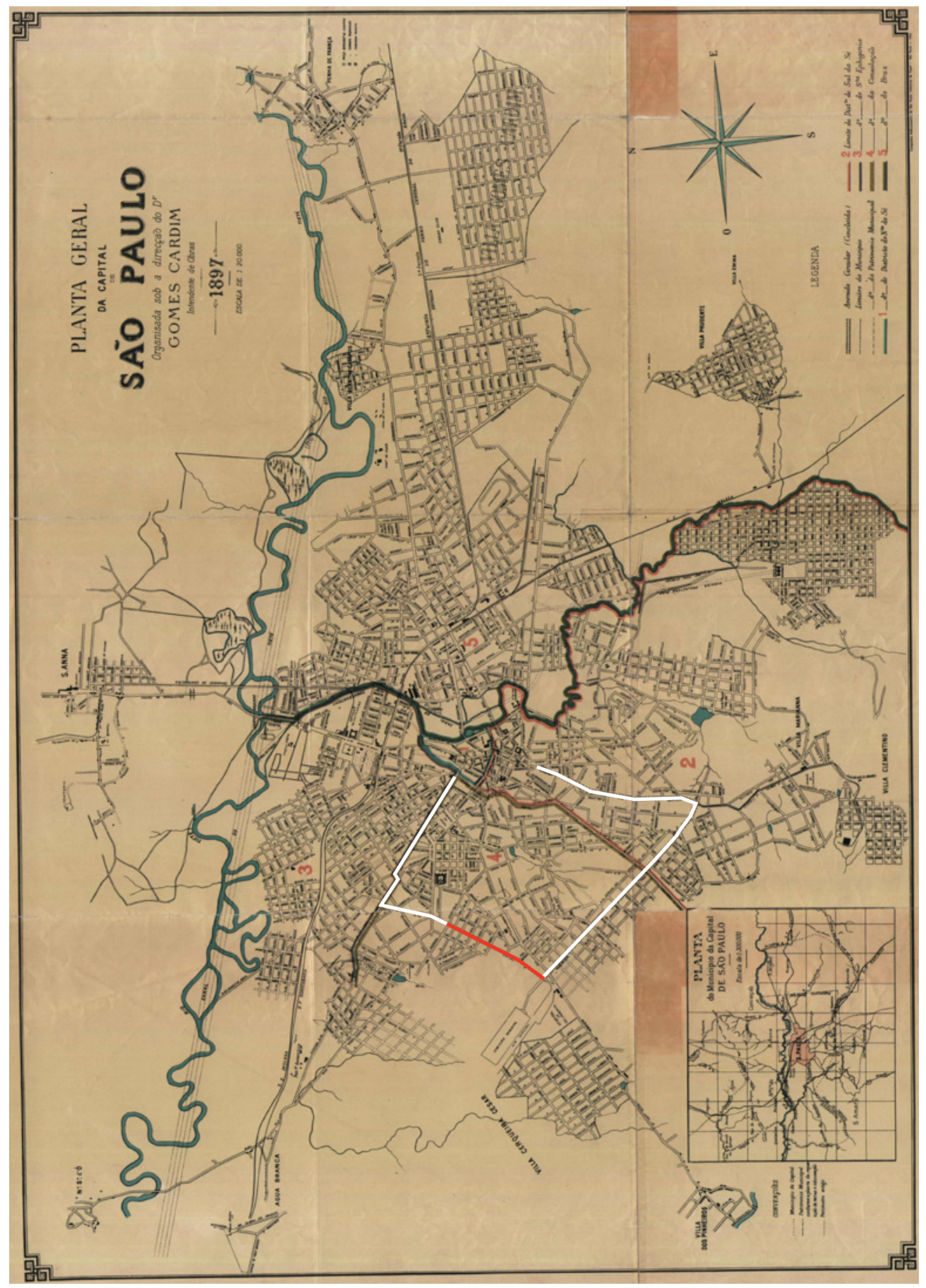

$N \in$

FIG. 5 - Nessa "Planta Geral da Capital de São Paulo organizada sob a direção do Dr. Gomes

Cardim - Intendente de Obras", está marcado o perímetro planejado para a Avenida Circular, que servia prioritariamente aos bairros das expansões Oeste e Sudoeste da cidade. Da direita para a esquerda, no sentido horário, estão marcadas: Rua Vergueiro (em branco); Avenida Paulista (em branco); Rua Itatiaia (em vermelho); Avenida Angélica (ainda em projeção, em branco); Rua São João (em branco). Fonte: Repositório Digital do Arquivo Público do Estado de São Paulo. 


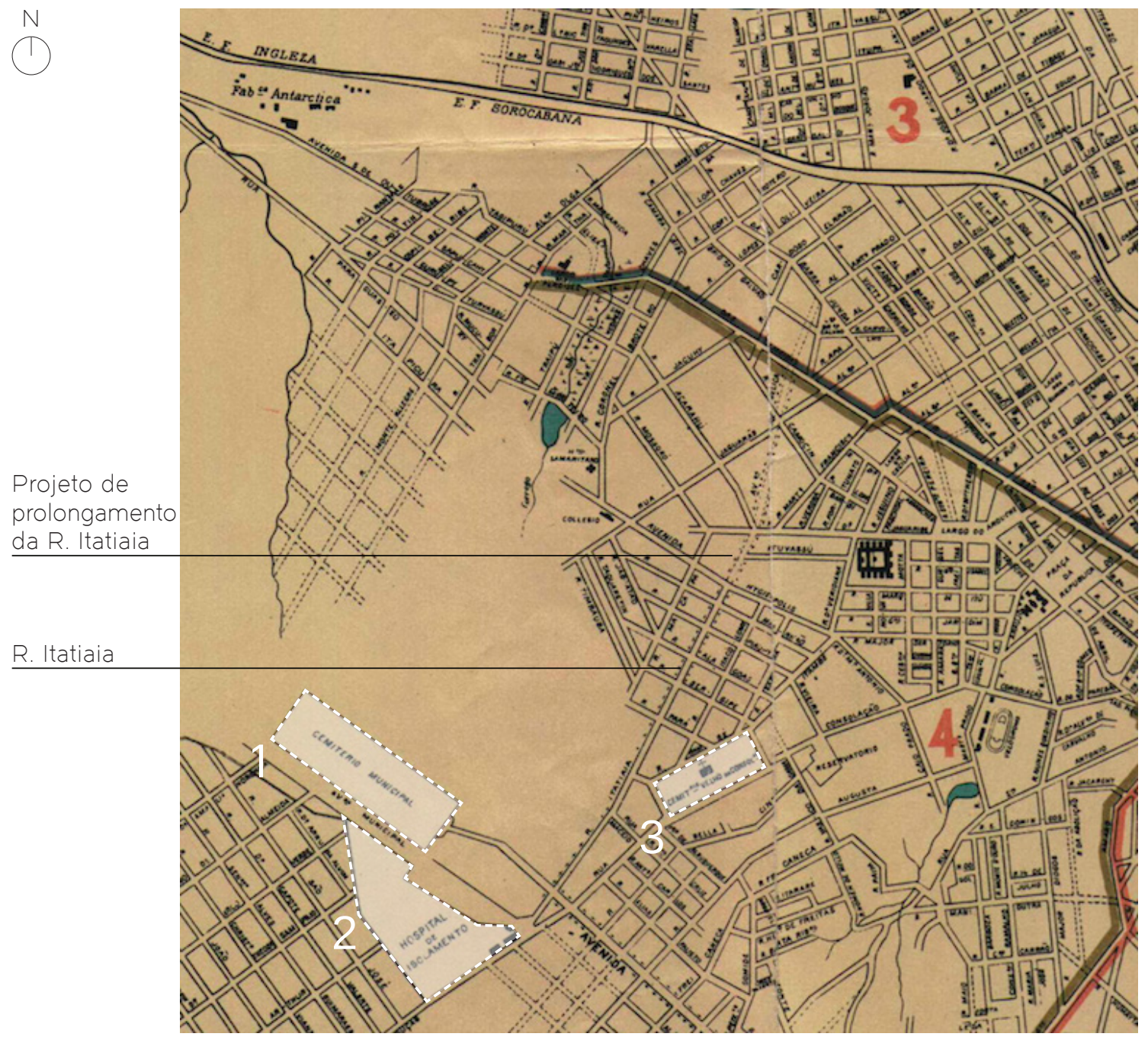

FIG. 6 - Nesse recorte da Planta Geral de Gomes Cardim (1897), podemos observar a peculiar localização da Rua Itatiaia. No mapa estão marcados: (1) Cemitério Municipal; (2) Hospital de Isolamento e (3) Cemitério da Consolação. Fonte: Repositório Digital do Arquivo Público do Estado de São Paulo. 


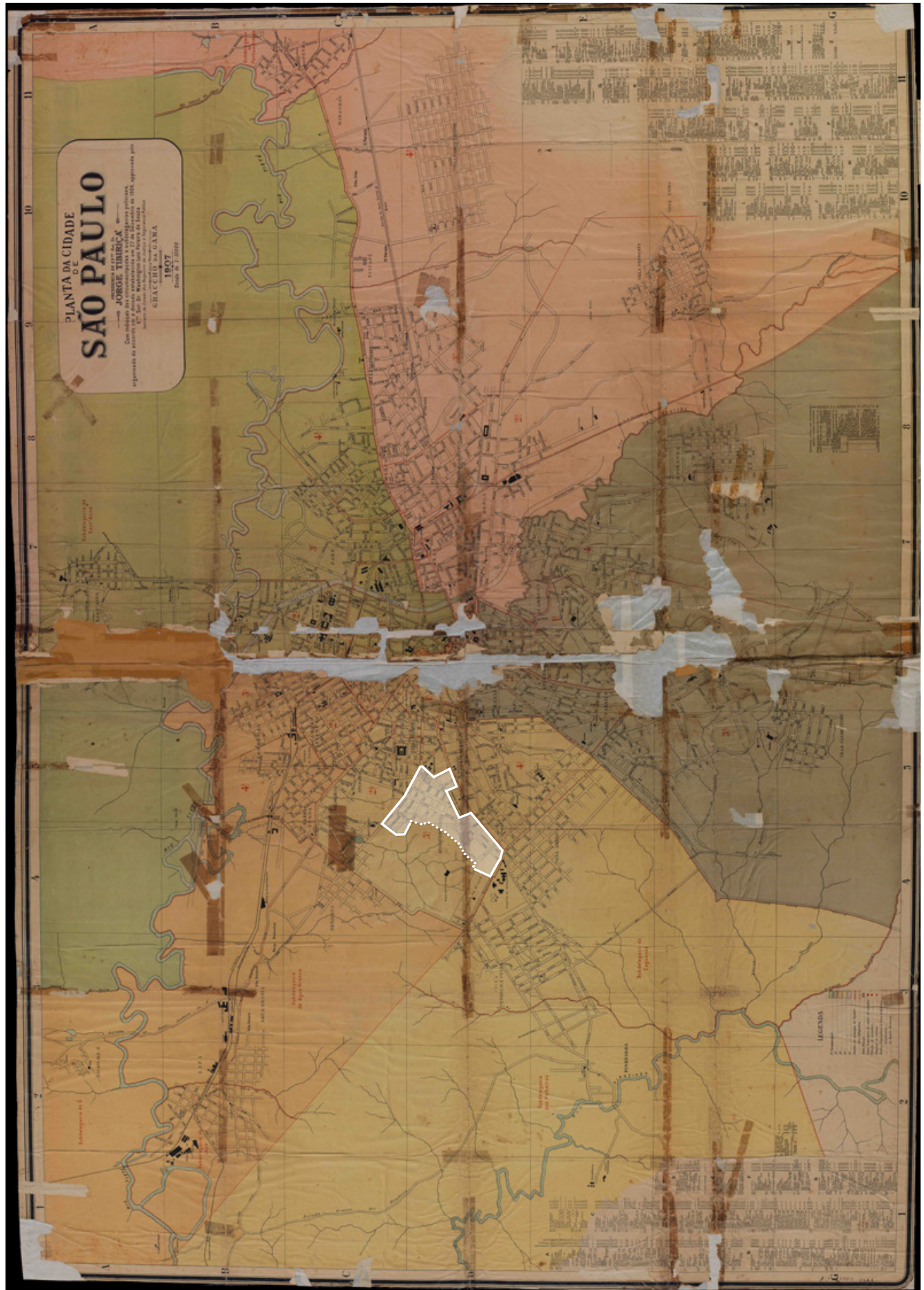

$N \in$

FIG. 7 - "Planta da Cidade de São Paulo" realizada por Graccho da Gama (1907), na qual podemos observar a posição de limite urbano do loteamento de Higienópolis. Uma posição que, como veremos, repercutia ambiguamente nos agentes sociais, ora favorecendo a experiência e percepção daquele espaço como tranquilo e resguardado, ora como ermo e isolado. Fonte: Repositório Digital do Arquivo Público do Estado de São Paulo. 


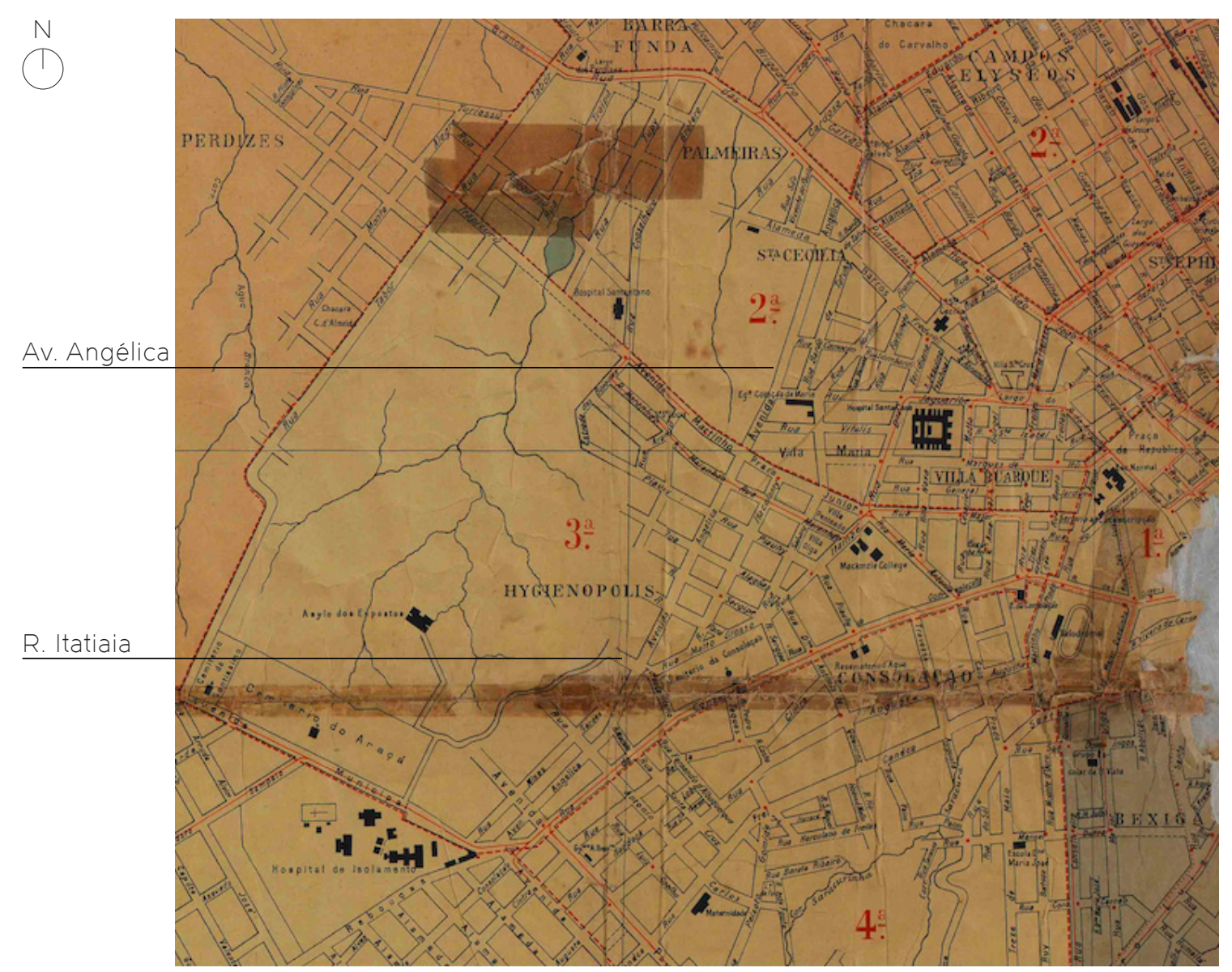

FIG. 8 - Nesse recorte da Planta da Cidade de São Paulo realizada por Graccho da Gama (1907), podemos identificar claramente as duas vias compuseram o que hoje conhecemos unitariamente como Avenida Angélica. Até esse ano, sua parte superior, que compreendia da Avenida Martinho Prado Junior (hoje conhecida como Avenida Higienópolis) até a Avenida Municipal (hoje Av. Dr. Arnaldo), ainda era chamada de Rua Itatiaia, e teve seu traçado realizado por Nothmann e Burchard entre 1891-1896. A seção inferior à Avenida Martinho Prado, chegando até a Rua das Palmeiras, era chamada Avenida Angélica, alcunha autocelebrativa atribuída por sua própria realizadora, Maria Angélica de Sousa Queiroz Aguiar de Barros, em 1898. Ainda nessa imagem, podemos observar o gradativo avanço do arruamento da região, que permanecera como um dos confins da cidade até a abertura do Pacaembu (1925). Fonte: Repositório Digital do Arquivo Público do Estado de São Paulo. 


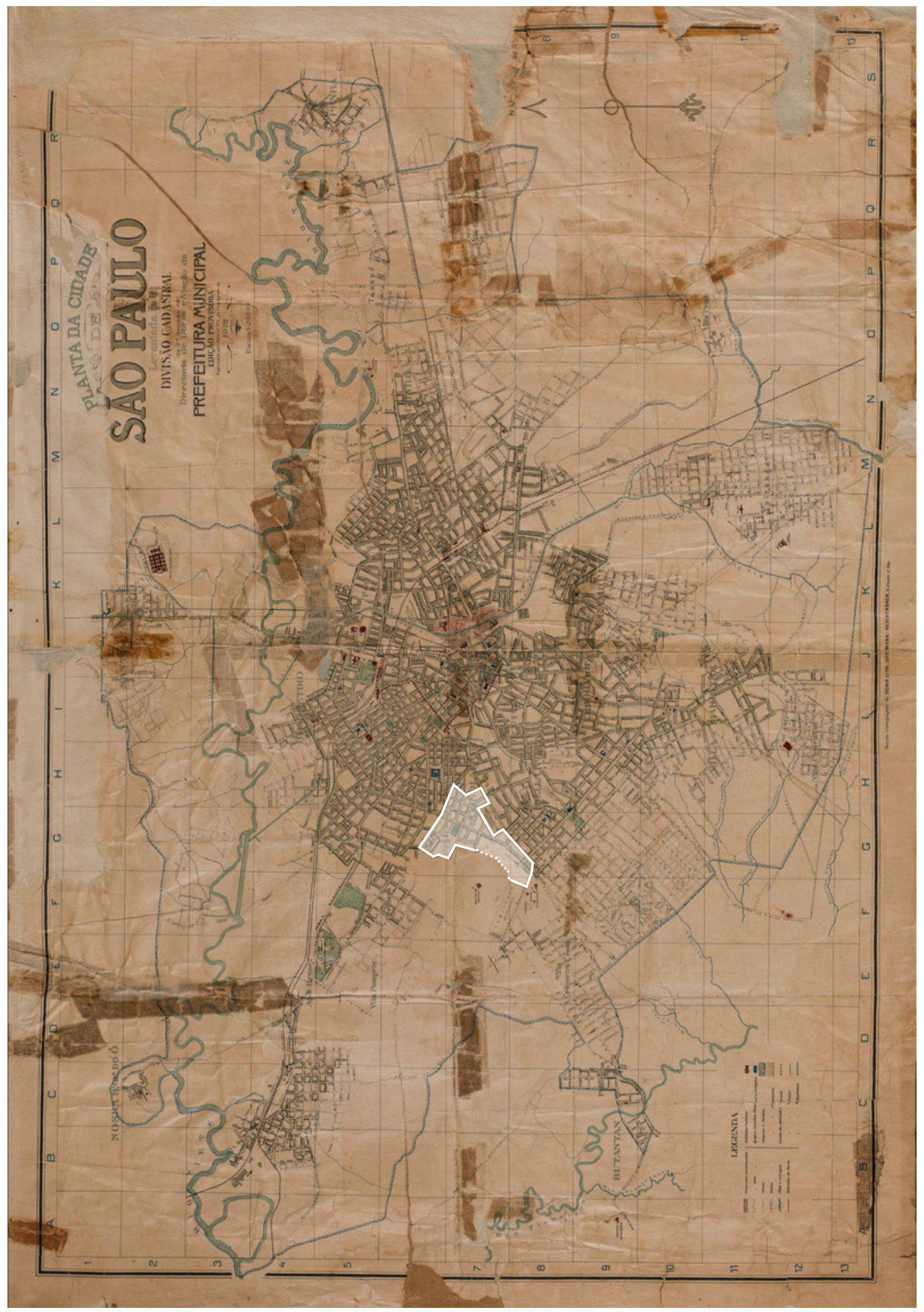

$N \in$

FIG. 9 - "Planta da Cidade de São Paulo" realizada pela Diretoria de Obras e Viação da Prefeitura Municipal (1916), na qual podemos observar que, em meados da década de 1910, Higienópolis seguia delimitando um dos confins da cidade. Fonte: Repositório Digital do Arquivo Público do Estado de São Paulo. 


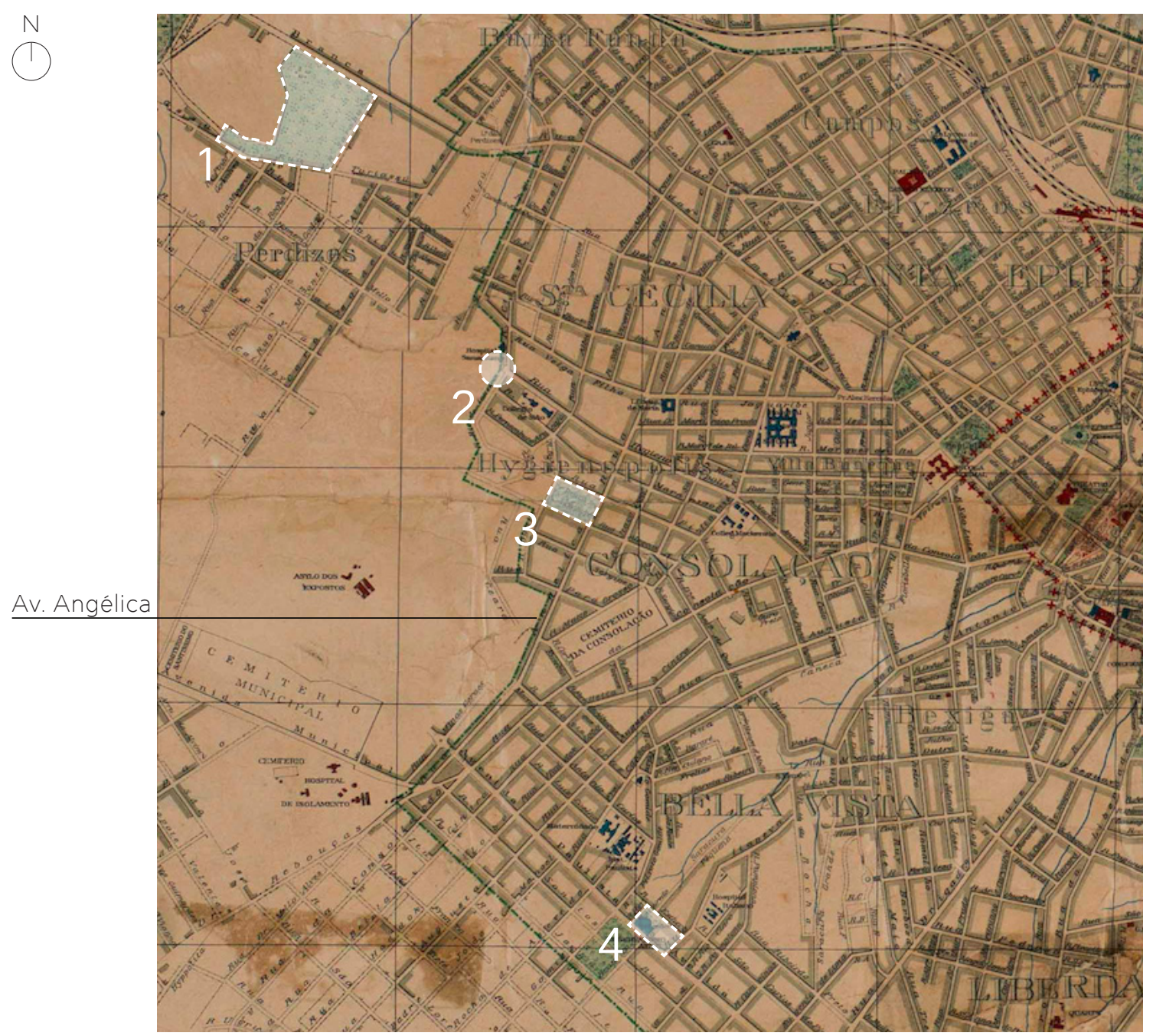

FIG. 10 - Nesse recorte da "Planta da Cidade de São Paulo" realizada pela Diretoria de Obras e Viação da Prefeitura Municipal (1916), podemos observar o gradativo arruamento do lado oeste da Avenida Angélica. Ainda aparecem apenas como projeções no mapa as ruas Minas Gerais e Ceará. Apesar das manchas em verde que ladeiam as vias, dando a impressão de preenchimento e consistência, à altura, a região ainda estava em processo de consolidação. Basta lembrar que, em 1913, Germaine vendera à Prefeitura um quarteirão inteiro para a realização da Praça Buenos Aires, indício de que ela ainda possuía muitos terrenos ociosos em suas mãos. Isso aponta que, à época, a paisagem do bairro devia ser ainda bastante instável e repleta de intervalos de terrenos baldios entre os palacetes, residências operárias e casas medianas que ali se erguiam.

Aqui também marcamos as intervenções que foram concebidas conjuntamente com a Praça Buenos Aires no Plano Bouvard: (1) Parque da Água Branca; (2) Belvedere da Rua Rio de Janeiro; (3) Praça Buenos Aires; (4) Belvedere da Avenida Paulista. Todos situados no quadrante Oeste da cidade, não tendo sido propostas construções de áreas verdes ou mirantes para nenhuma outra região da cidade, fora o Centro. Fonte: Repositório Digital do Arquivo Público do Estado de São Paulo. 


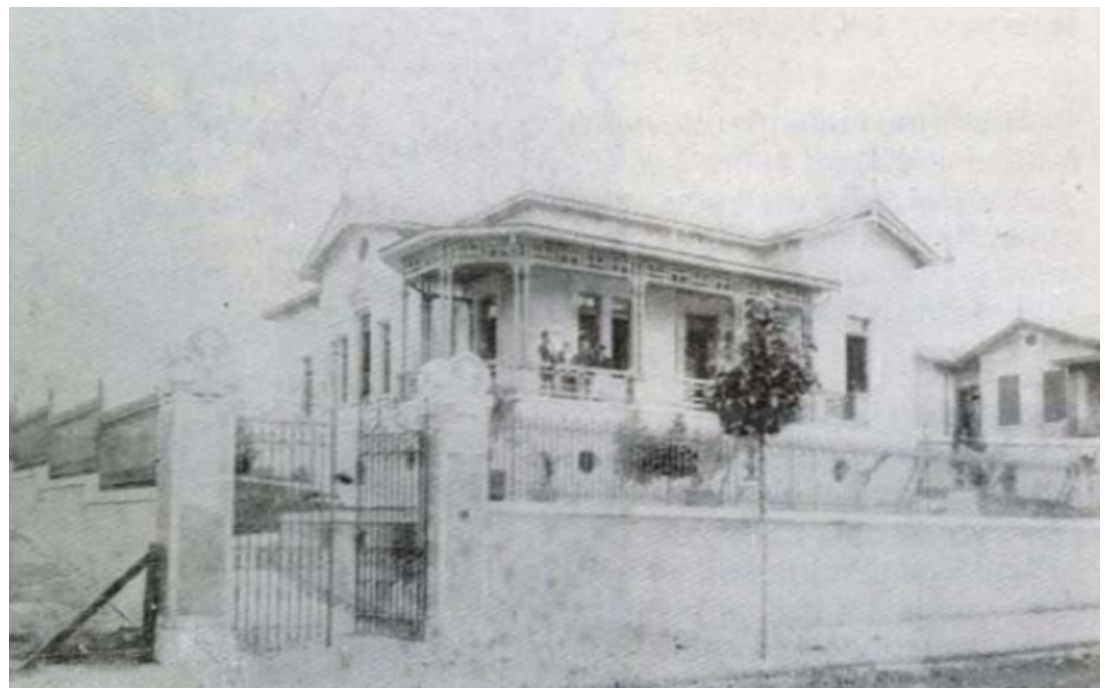

FIG. 11 - Foto da residência de Martinho Burchard, na Avenida Burchard, construída em 1897, s/d. Fonte: HOMEM, 1980, p. 82. 


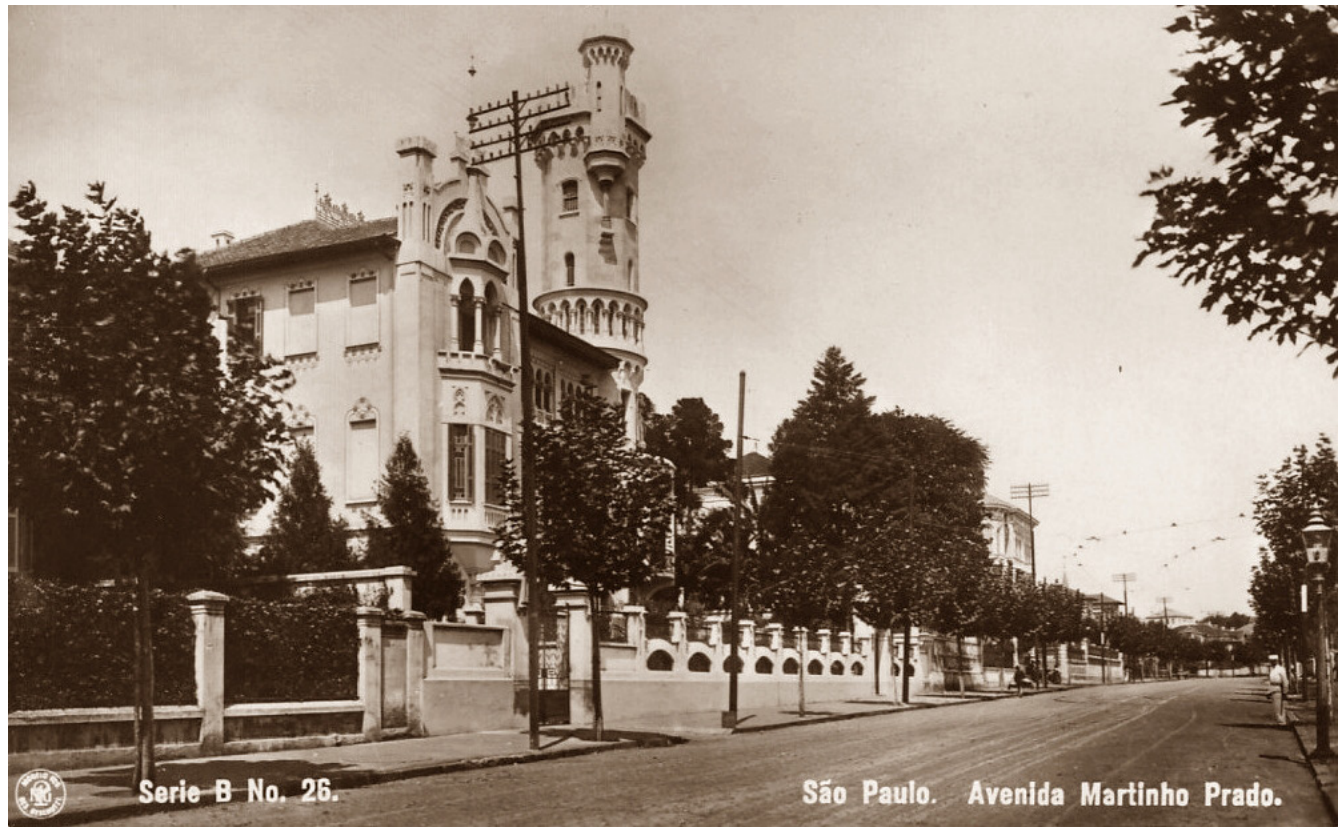

FIG. 12 - Postal “Avenida Martinho Prado" da Série B de Guilherme Gaensly, 1906. Fonte: GERODETTI e CORNEJO, 2002. 


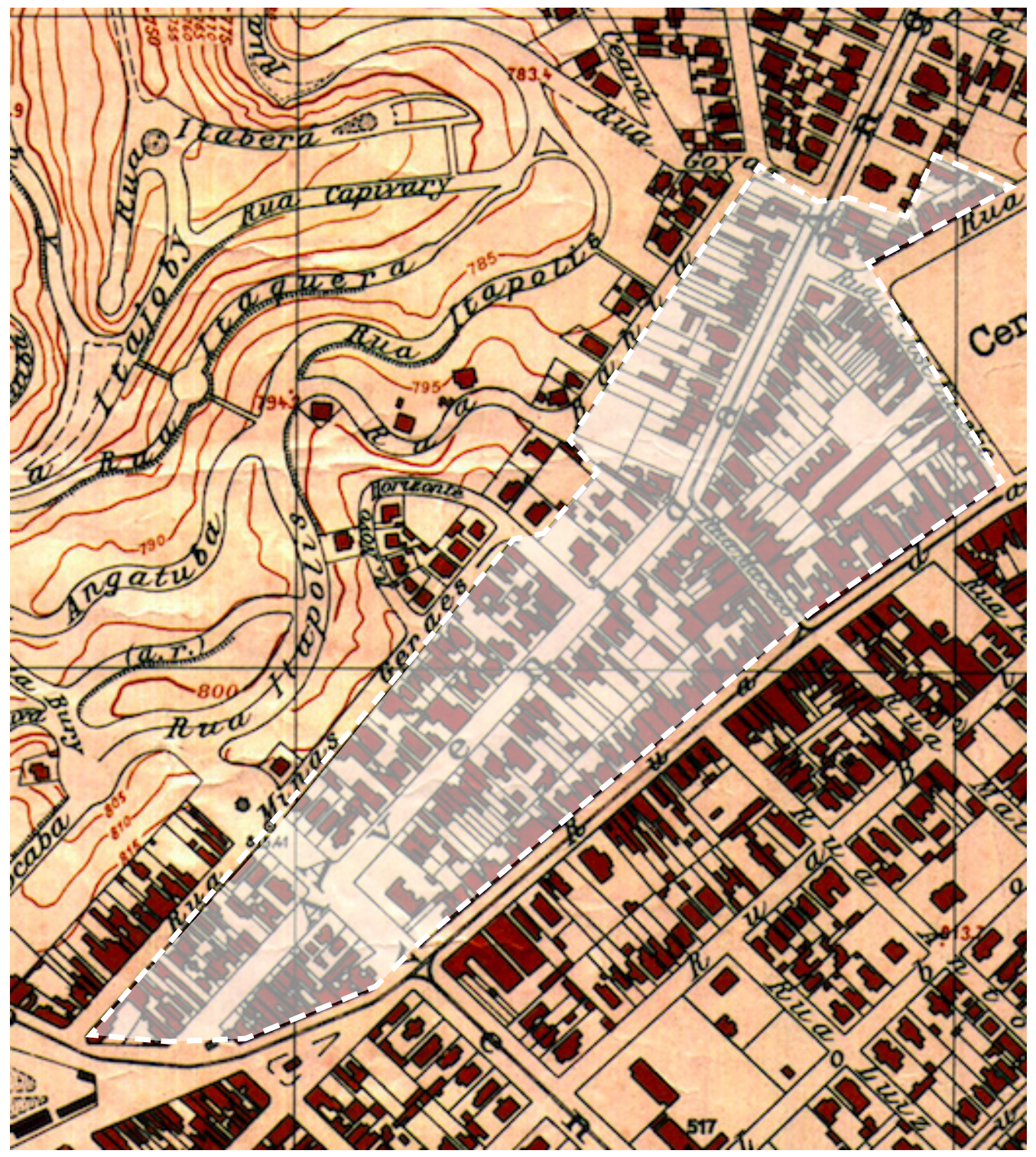

FIG. 13 - Ampliação de trecho do SARA-Brasil (1930) em que podemos observar a ocupação do topo da Avenida Angélica, nas proximidades do Cemitério da Consolação (na ponta direita) e da Avenida Paulista (no canto inferior da imagem). Percebe-se que essa região teve ocupação majoritária de residências de pequeno porte, em maioria geminadas, e implantadas em lotes bastante estreitos. Algumas possuem os recuos que foram obrigatórios em determinados momentos (18981902 e 1907 em diante), outras possuem recuos mínimos, notadamente abaixo do imposto pelas regulamentações, e ainda há as que estão diretamente alinhadas à via. Fonte: SARA-Brasil, 1930. 


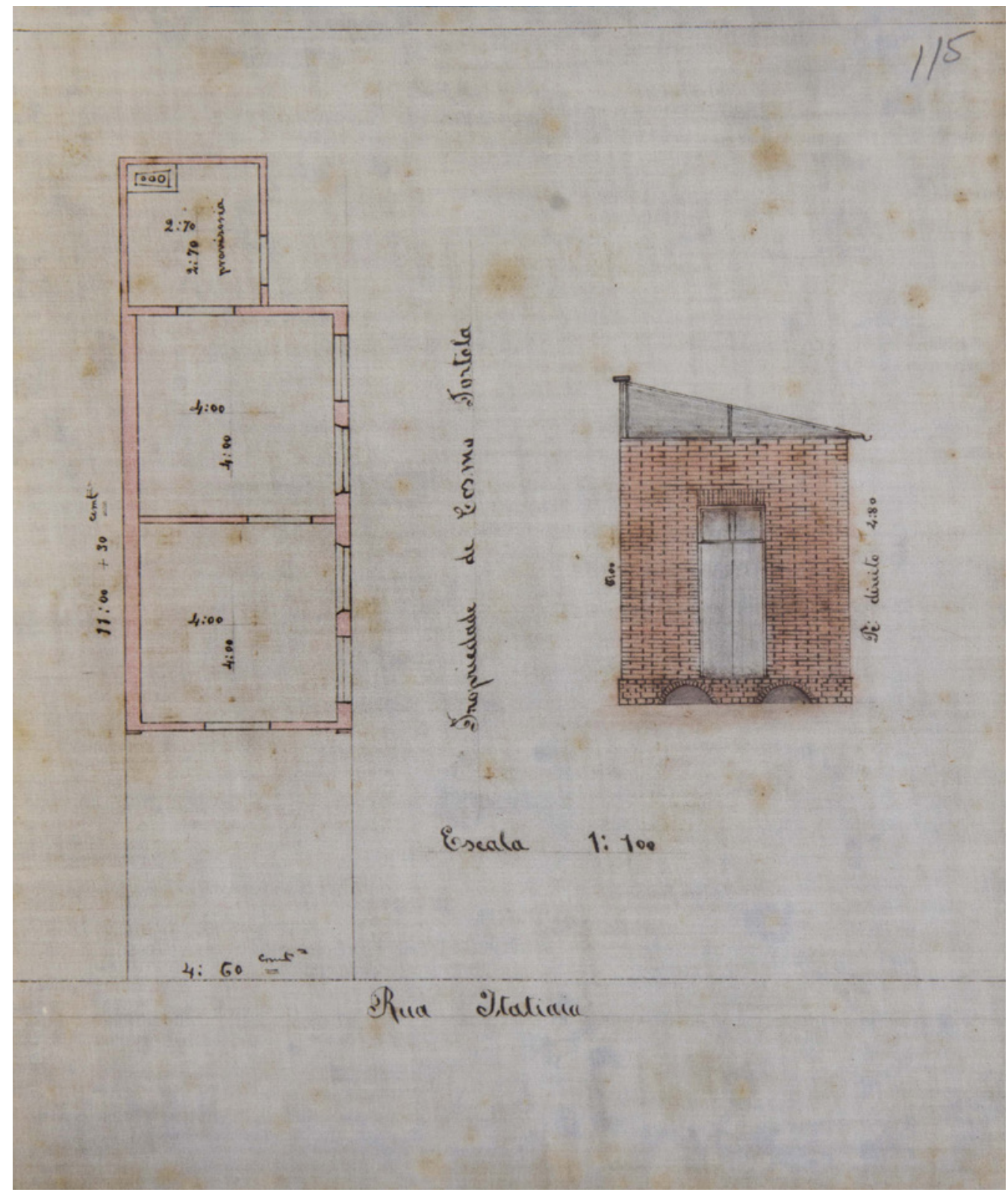

FIG. 14 - Residência construída por Cosmo Tortola em 1896. Terreno exíguo, com apenas 4,60m de frente, com construção bastante modesta, totalmente inadequada às Posturas estabelecidas em 1886. Fonte: Fundo de Obras Privadas do AHMSP, vol. 118, p. 114-115. 


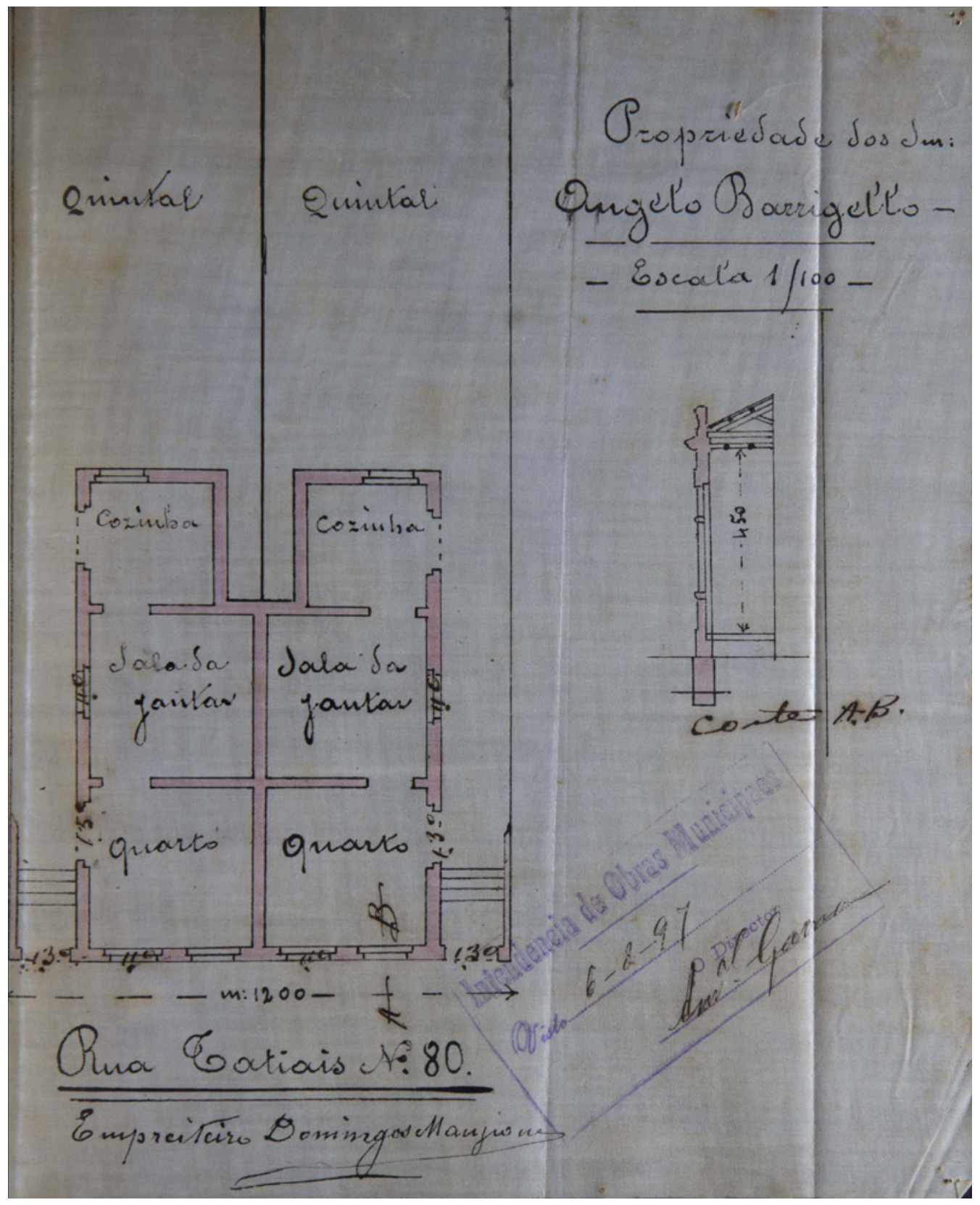

FIG. 15 - Residências geminadas construídas por Angelo Barrigelo em 1897. Ambas apenas com dois cômodos e cozinha, fora dos padrões municipais. Fonte: Fundo de Obras Privadas do AHMSP, vol. 162, p. 137-138. 


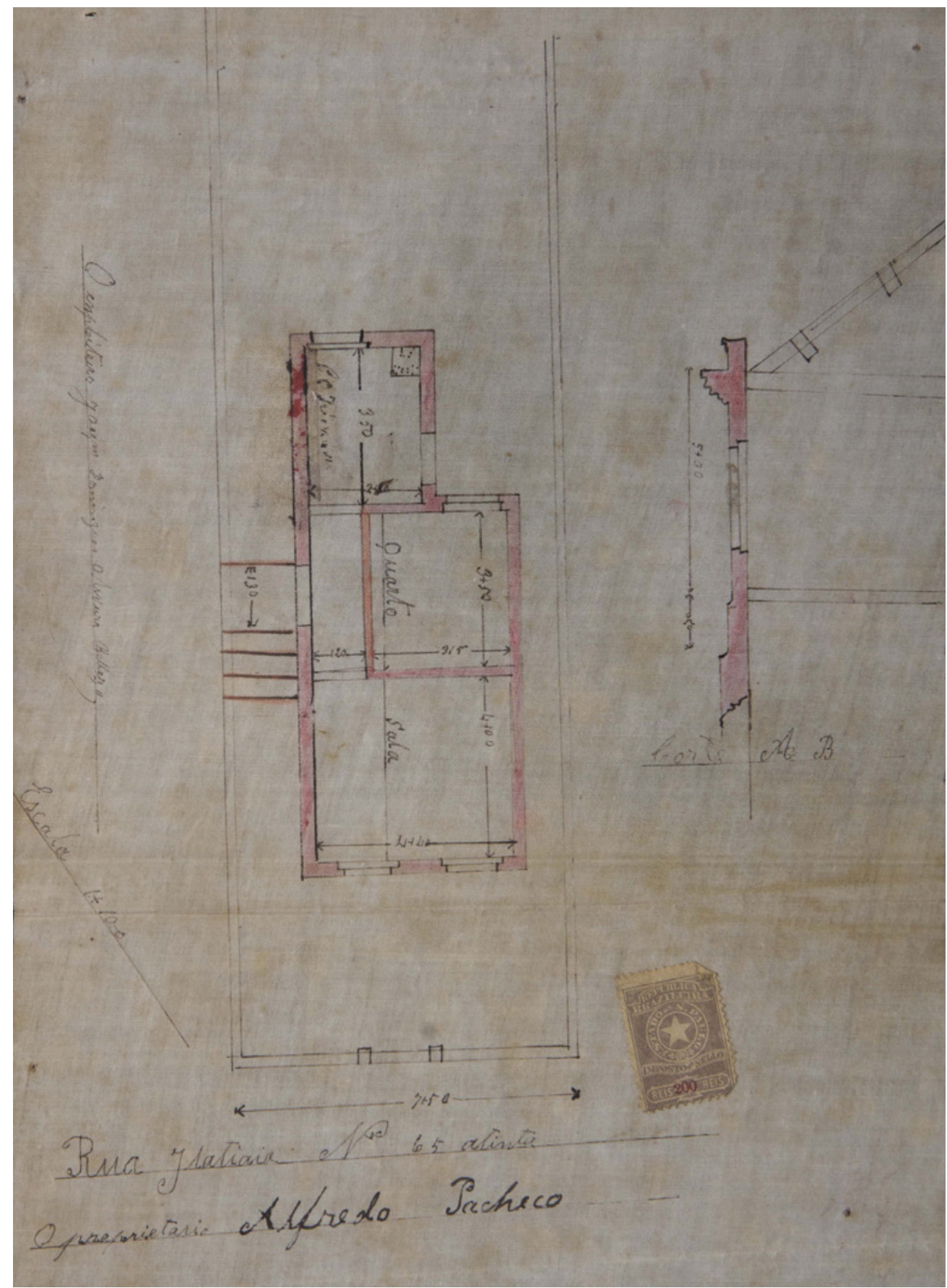

FIG. 16 - Residência construída por Alfredo Pacheco em 1899. Terreno exíguo, com apenas 4,60m de frente, com construção bastante modesta, também inadequada às posturas municipais. O prédio foi demolido em 1903 e substituído por uma casa à risca dos padrões regulamentares: três cômodos (sala e dois dormitórios) mais cozinha e banheiro de tamanhos mínimos. Essa foi a casa onde morou a esposa de Augusto Piedade até 1909 e que, a partir de 1912, passou a servir de residência às irmãs Augusta e Francisca, convertendo-se também em seu consultório dentário no ano seguinte. Fonte: Fundo de Obras Privadas do AHMSP, vol. 239, p. 81-3. 


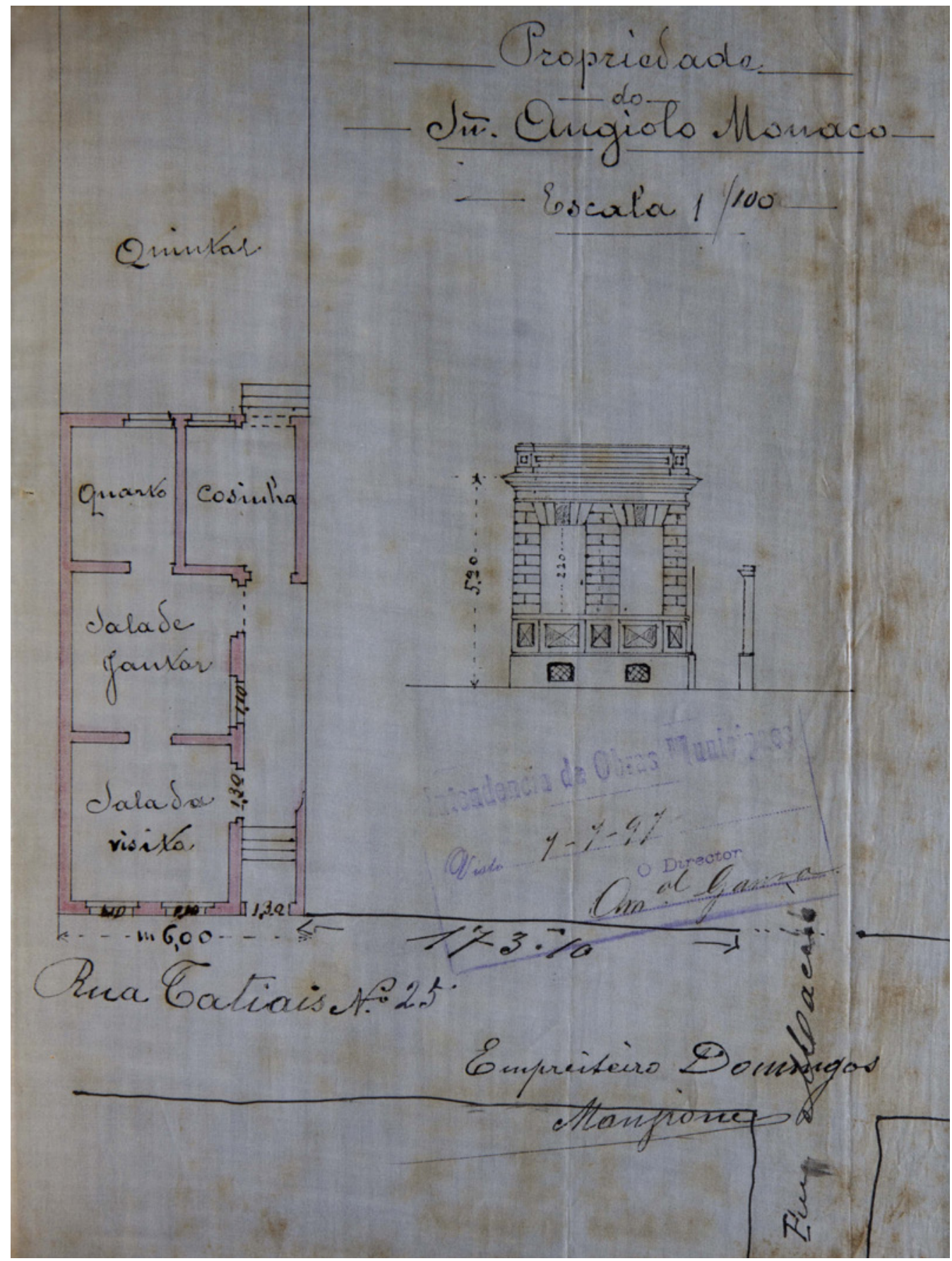

FIG. 17 - Residência construída por Angiolo Monaco em 1897, em desacordo com o padrão municipal, pois o Código de Posturas de 1886 proibiu quartos de dormir vizinhos à cozinha. Mesmo assim, o projeto foi aprovado sem demandas da Diretoria de Obras. Notar que a residência de Angiolo, assim como as outras construídas nessa época no topo da Avenida, não possuía banheiro. Isso ocorria pela ausência de esgoto canalizado nessa parte da via, obrigando a latrina a ficar no fundo do lote, onde poderia ser adequadamente instalada uma fossa séptica. Fonte: Fundo de Obras Privadas do AHMSP, vol. 162, p. 141-143. 


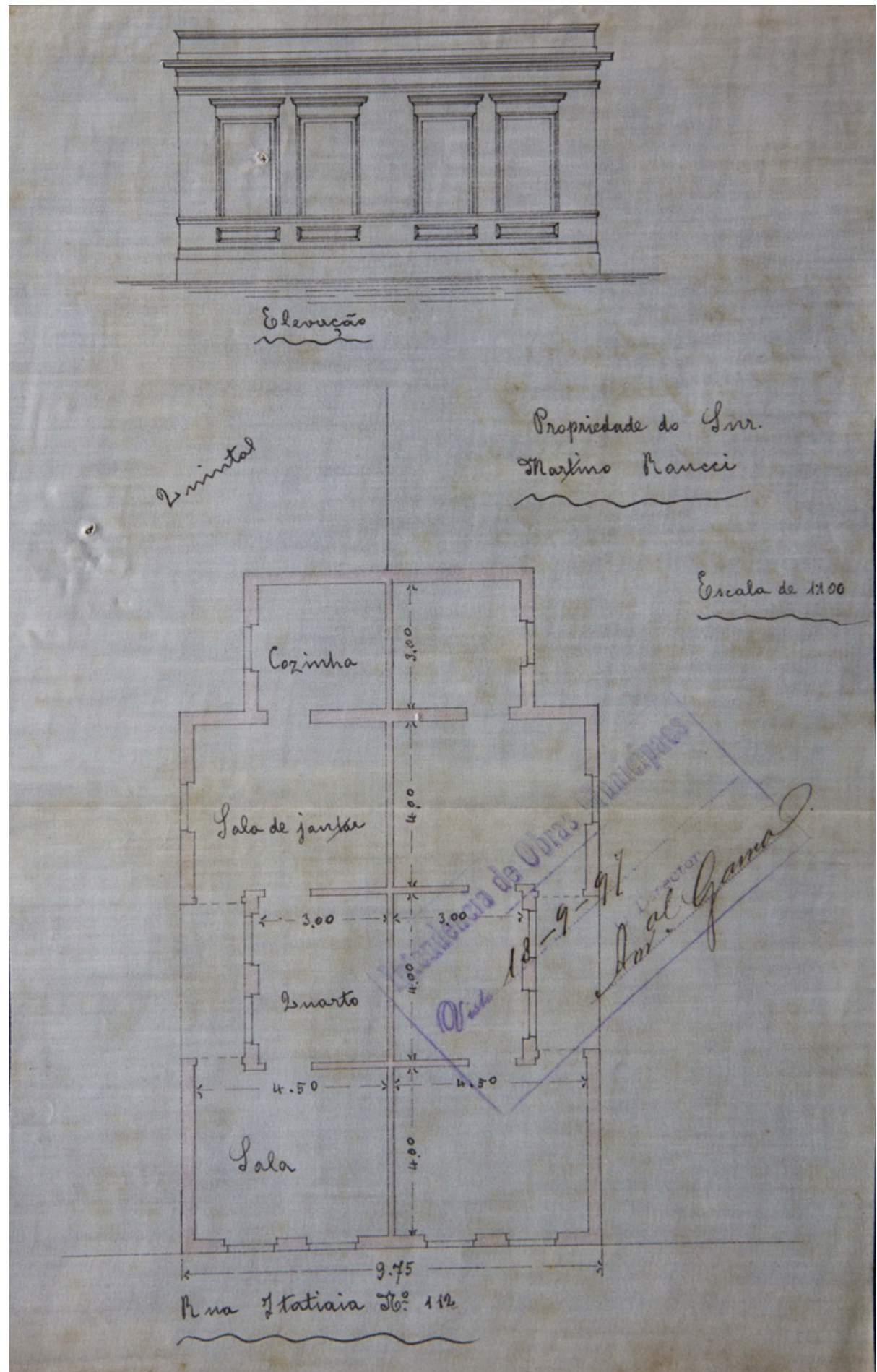

FIG. 18 - Residências geminadas construídas por Martim Raucci em 1897. Notar a ausência de corredor interno, sendo a ligação entre a sala e a sala de jantar realizada por dentro do quarto. Fonte: Fundo de Obras Privadas do AHMSP, vol. 162, p. 175-176. 


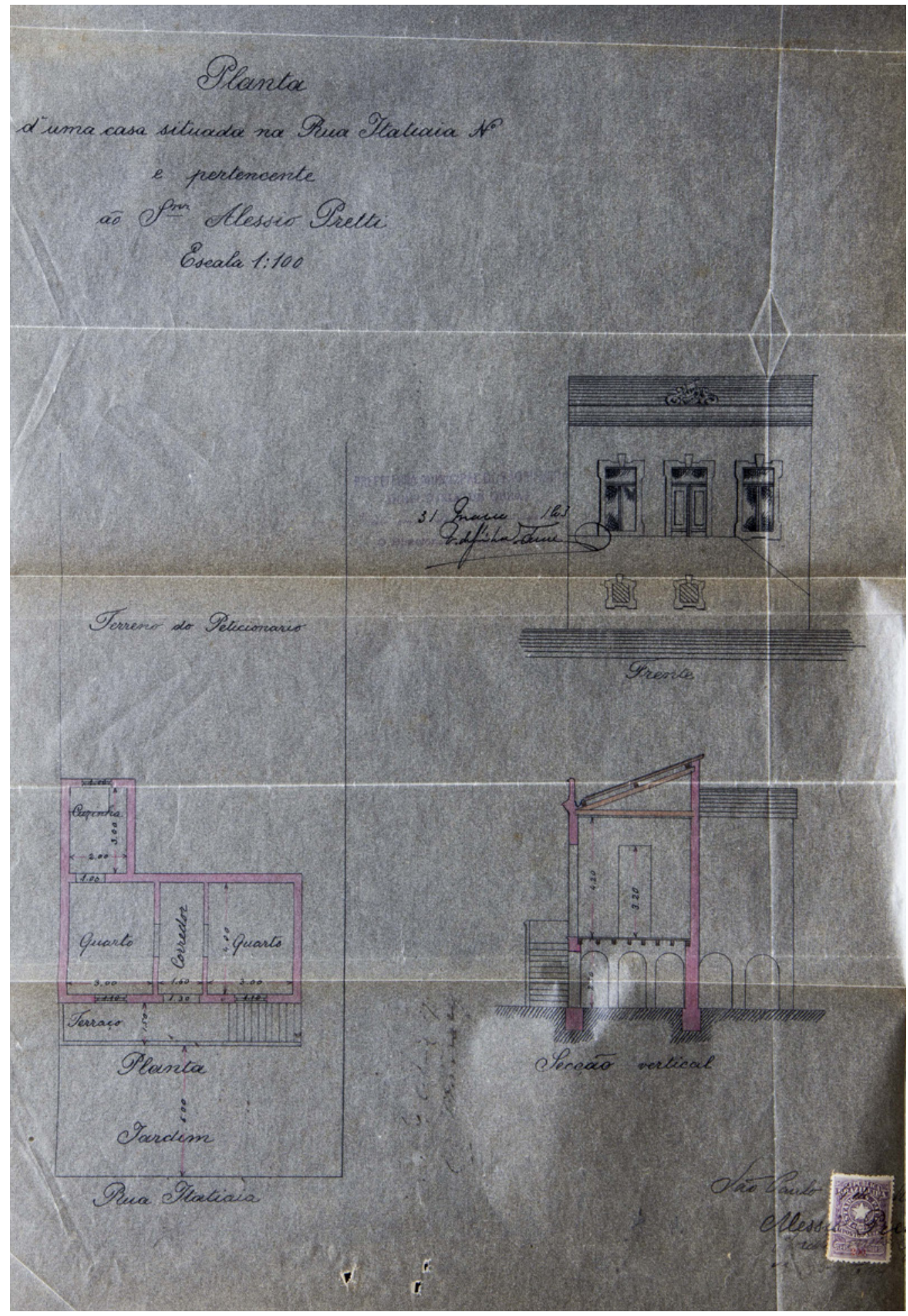

FIG. 19 - Residência de Alessio Pretti, construída em 1903. A peculiar divisão de dois quartos por um corredor parece sugerir que o imóvel era destinado ao aluguel simultâneo de duas famílias. Fonte: Fundo de Obras Privadas do AHMSP, vol. 357, p. 97-98. 


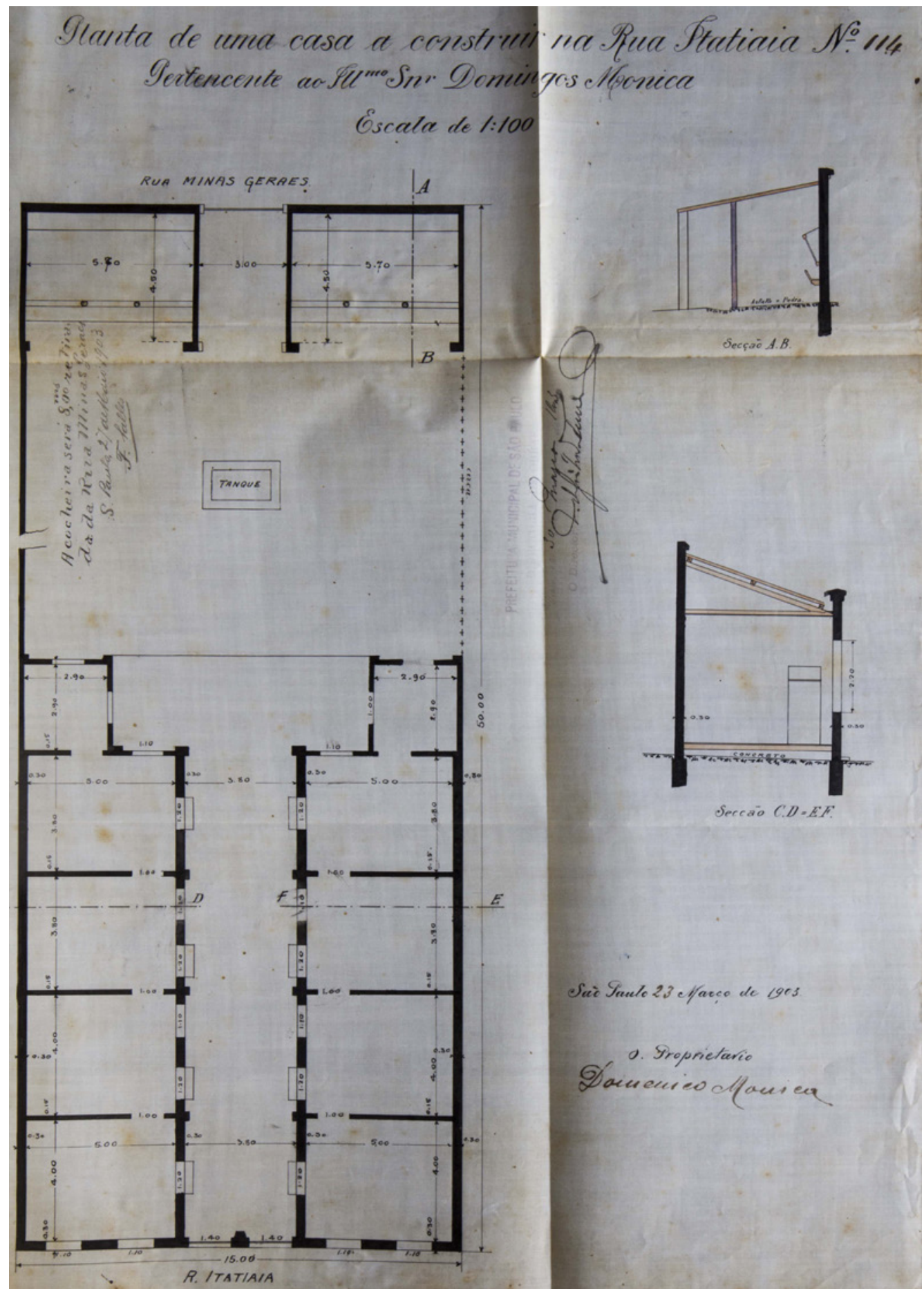

FIG. 20 - Duas casas construídas por Domingos Monica em 1903. Apesar de não serem geminadas entre si, compartilham um pátio central comum, com um tanque provavelmente destinado ao cuidado de cavalos, pois no fundo há duas cocheiras. Notar que os cômodos são posicionados em enfilade, inexistindo, portanto, a privacidade garantida pelos corredores independentes. Fonte: Fundo de Obras Privadas do AHMSP, vol. 357, p. 112-113. 


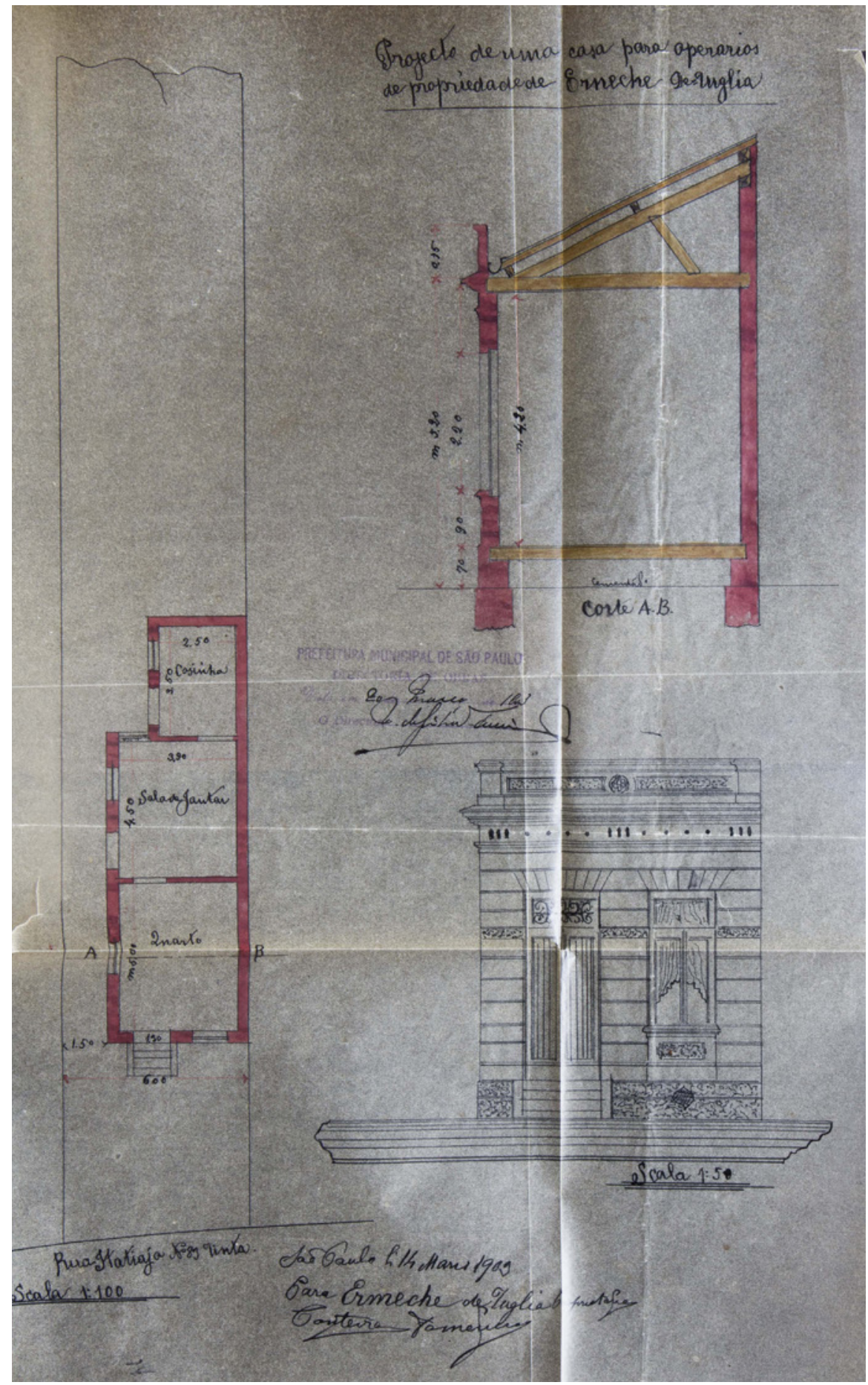

FIG. 21 - Residência construída por Erneche Detuglia. Como tantas outras, com apenas dois cômodos e cozinha, mas aprovada, mesmo em desacordo com o padrão municipal. Notar que para uma casa extremamente exígua, a fachada, ao menos no desenho, é inusitadamente ornamentada. Fonte: Fundo de Obras Privadas do AHMSP, vol. 357, p. 115-116. 


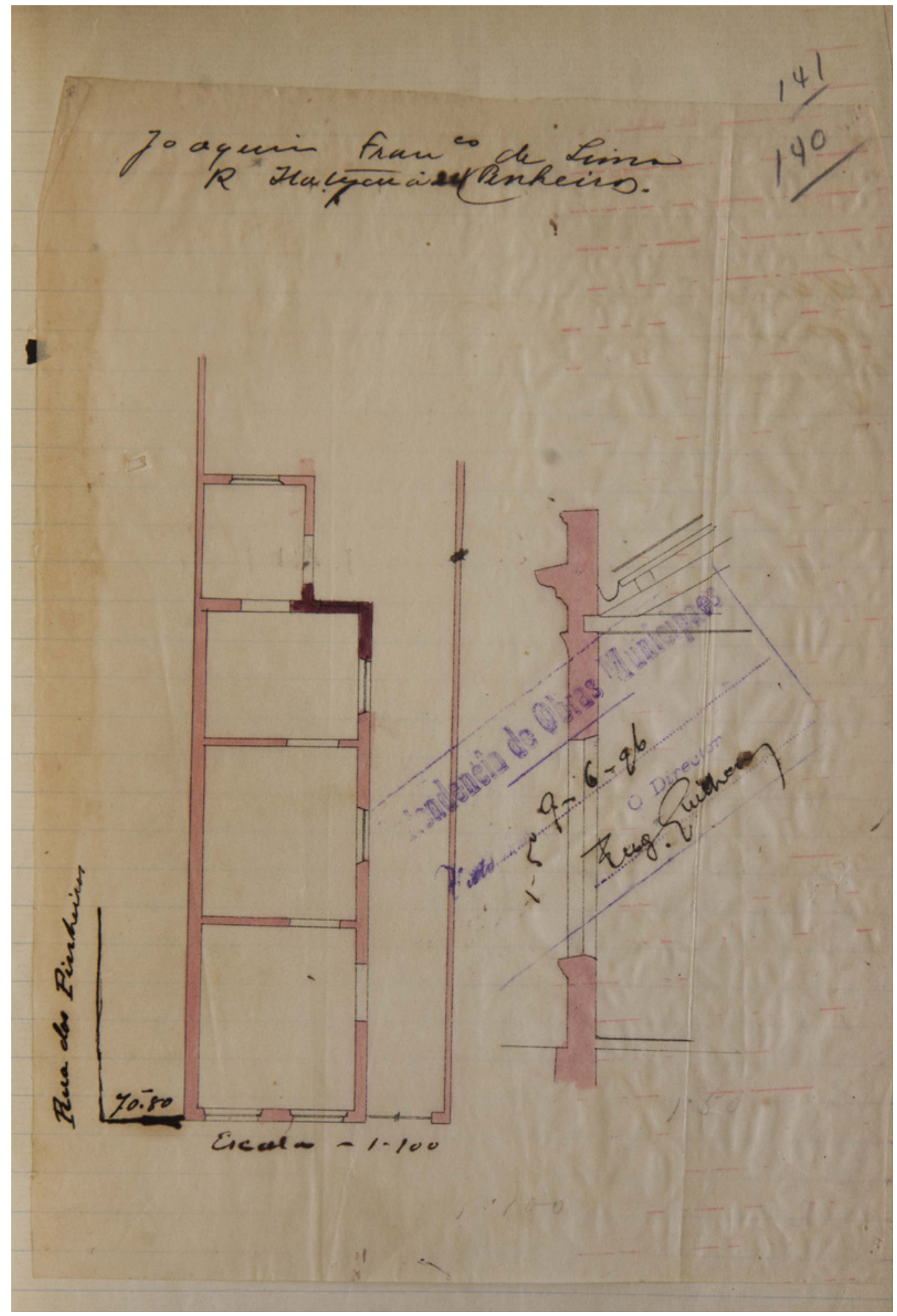

FIG. 22 - Residência de Joaquim Francisco de Lima, porteiro do Hospital de Isolamento, erguida em 1896. Fonte: Fundo de Obras Privadas do AHMSP, vol. 118, p. 139-140. 


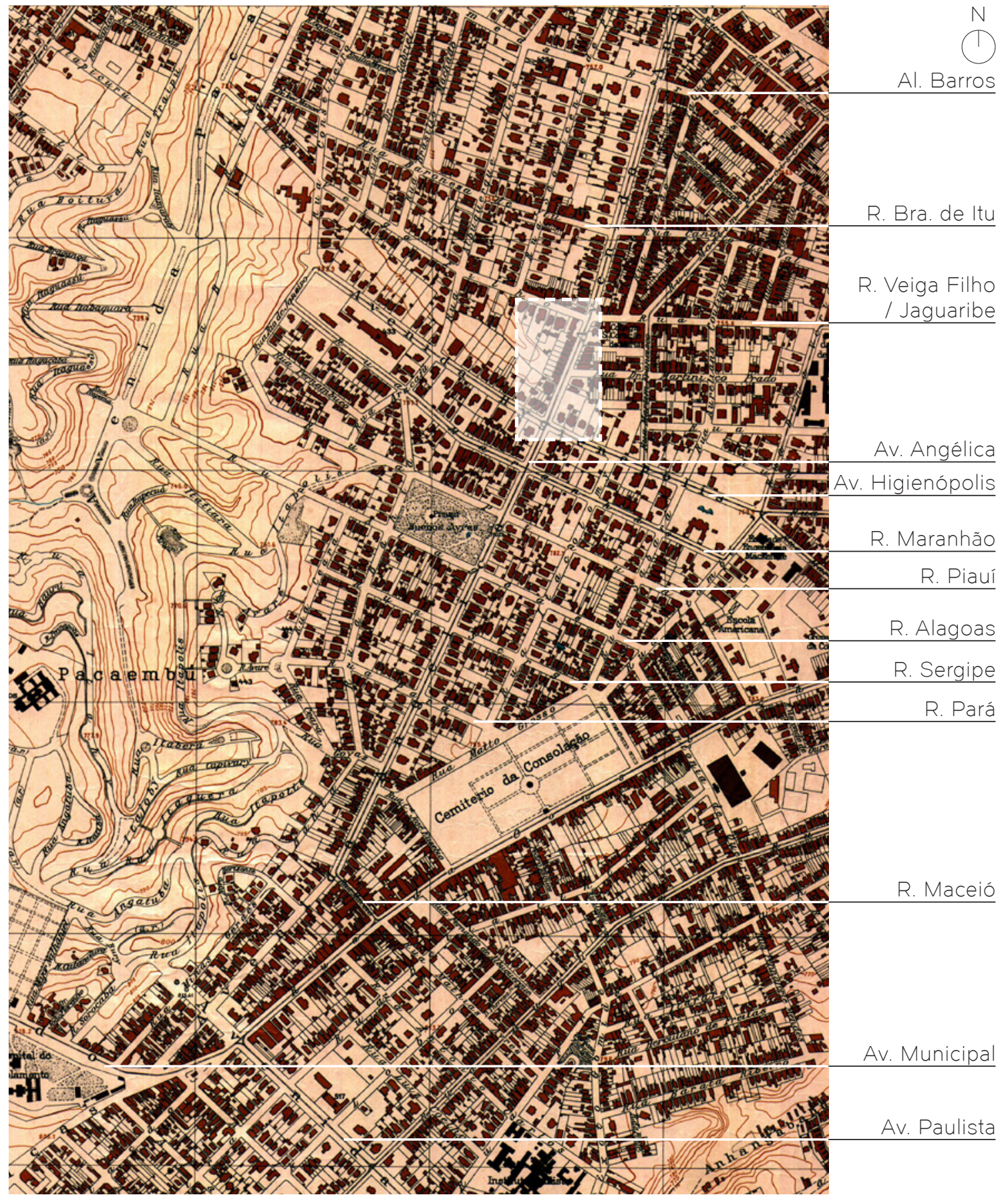

FIG. 23 - Excerto do SARA-Brasil no qual pode-se ver o posicionamento das residências construídas por Antônio Ferreira da Rosa (marcado em branco), na Avenida Angélica entre a Rua Jaguaribe e a Avenida Higienópolis. Fonte: SARA-Brasil, 1930. 


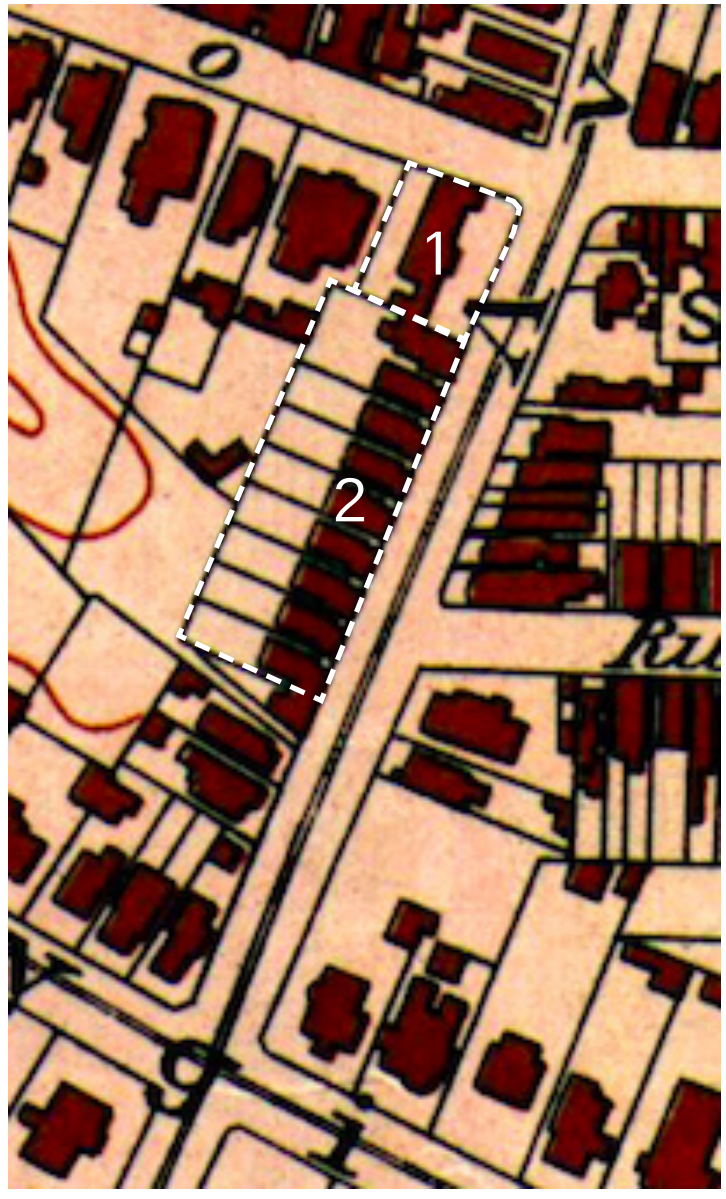

FIG. 24 - Excerto do SARA-Brasil no qual podemos ver o posicionamento mais preciso das residências construídas por Antônio Ferreira da Rosa. Ao contrário da maior parte dos abastados da região, da Rosa constrói sua residência (1) com frente para a Rua Jaguaribe, e não para a Avenida. De frente para essa estão as suas casas de aluguel (2), atitude que evidencia certa indiferença do coronel em relação ao projeto de tornar a Angélica uma passarela exclusiva e elegante das elites. Fonte: SARA-Brasil, 1930. 


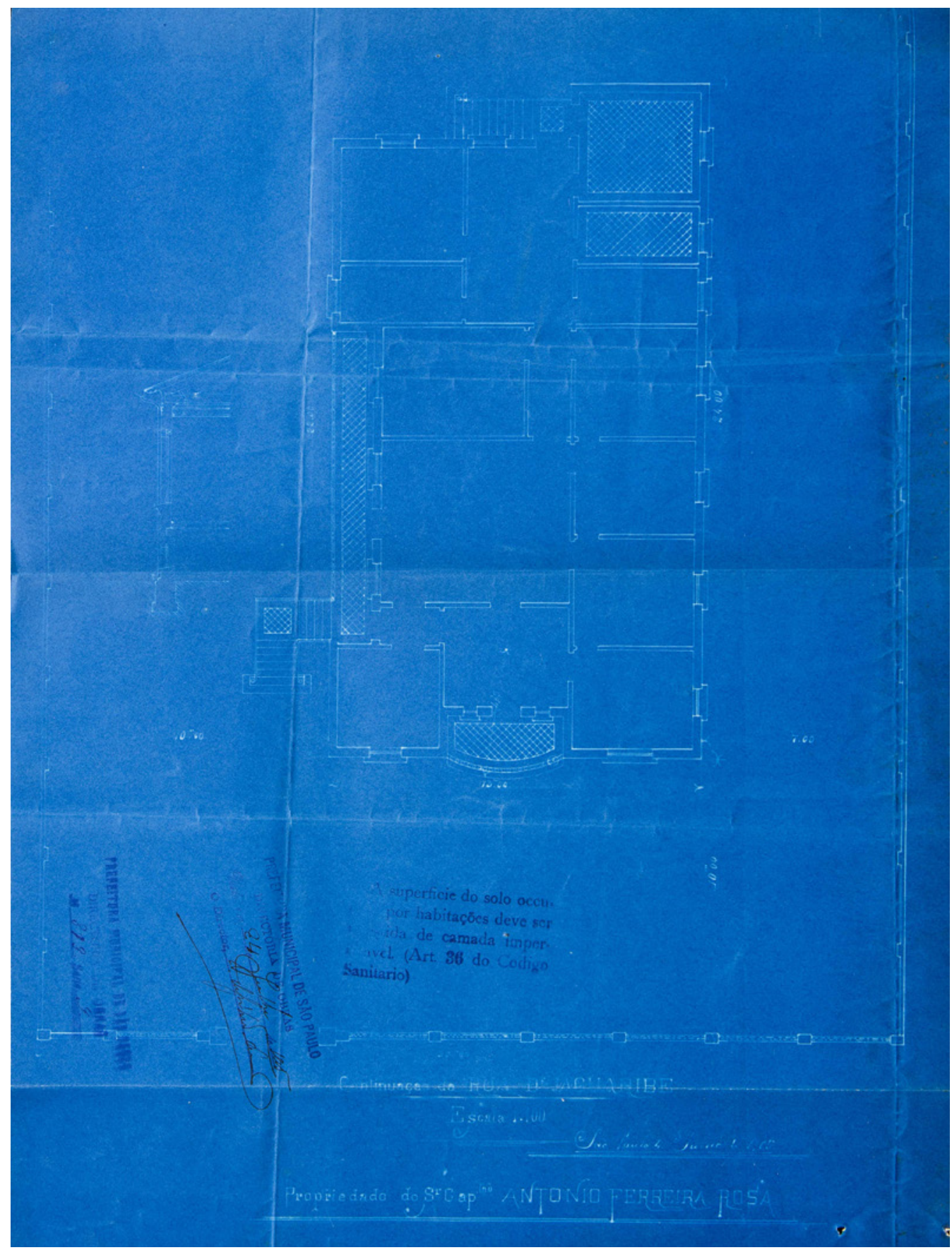

FIG. 25 - Planta da residência do palacete de Antônio Ferreira da Rosa, construído em 1905. Fonte: Fundo de Obras Privadas do AHMSP, vol. 413, p. 126-127. 

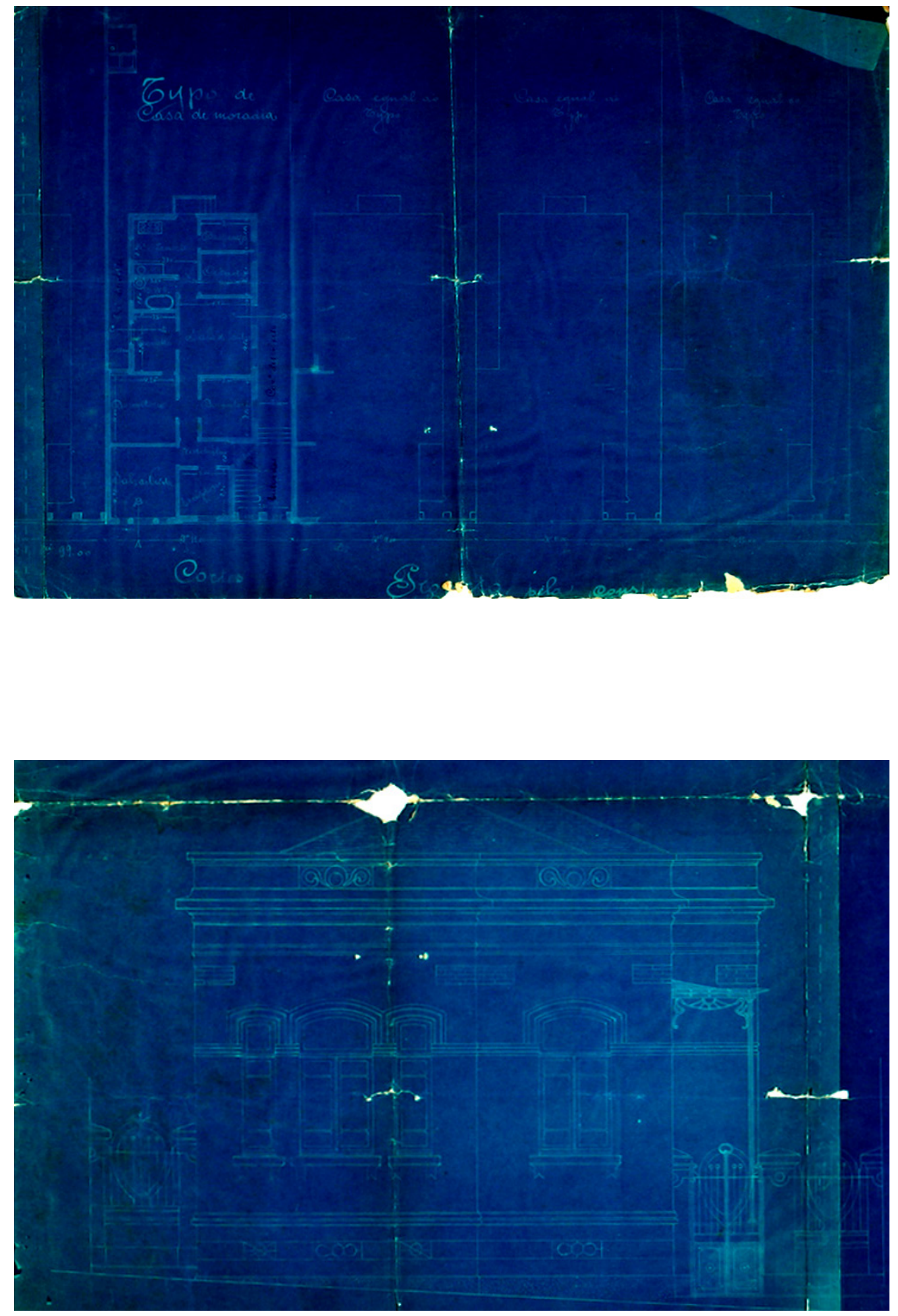

FIG. 26 - Planta e elevação das nove residências de médio padrão construídas por Antônio Ferreira da Rosa em 1905. Fonte: Fundo de Obras Privadas do AHMSP, vol. 413, p. 132-133 


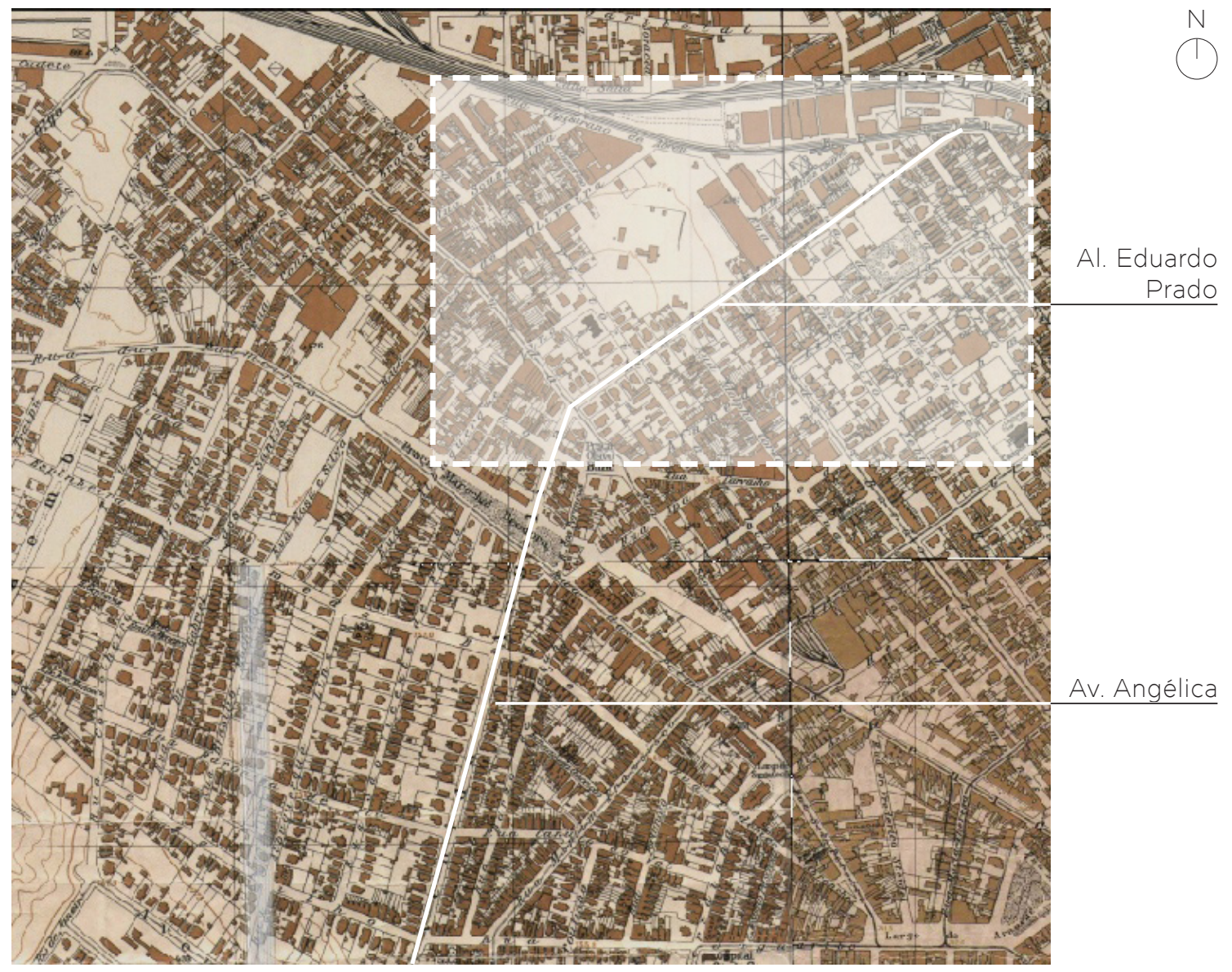

FIG. 27 - Excerto do SARA-Brasil no qual podemos apreender o prolongamento da Angélica até a Alameda Eduardo Prado, pretendido por Antônio da Silva Prado desde 1898. Fonte: SARABrasil, 1930. 


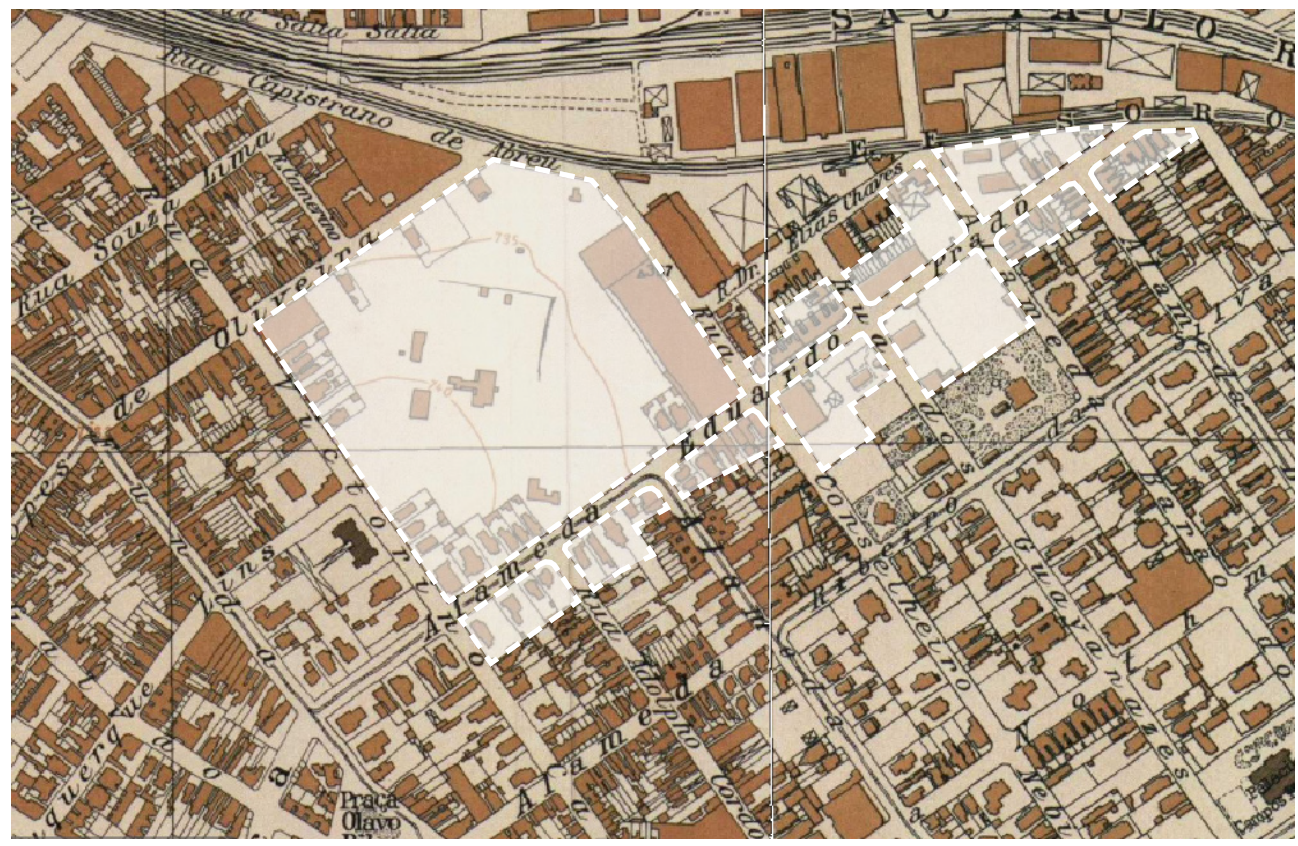

FIG. 28 - Excerto do SARA-Brasil no qual podemos apreender a tendência heterogênea da ocupação das terras de Antônio da Silva Prado (em branco). A Chácara do Carvalho, residência de Prado, é o terreno de maiores proporções no centro da imagem. Em seus arredores, podemos observar a construção de palacetes, conjuntos geminados de casas operárias e galpões industriais. Fonte: SARA-Brasil, 1930. 


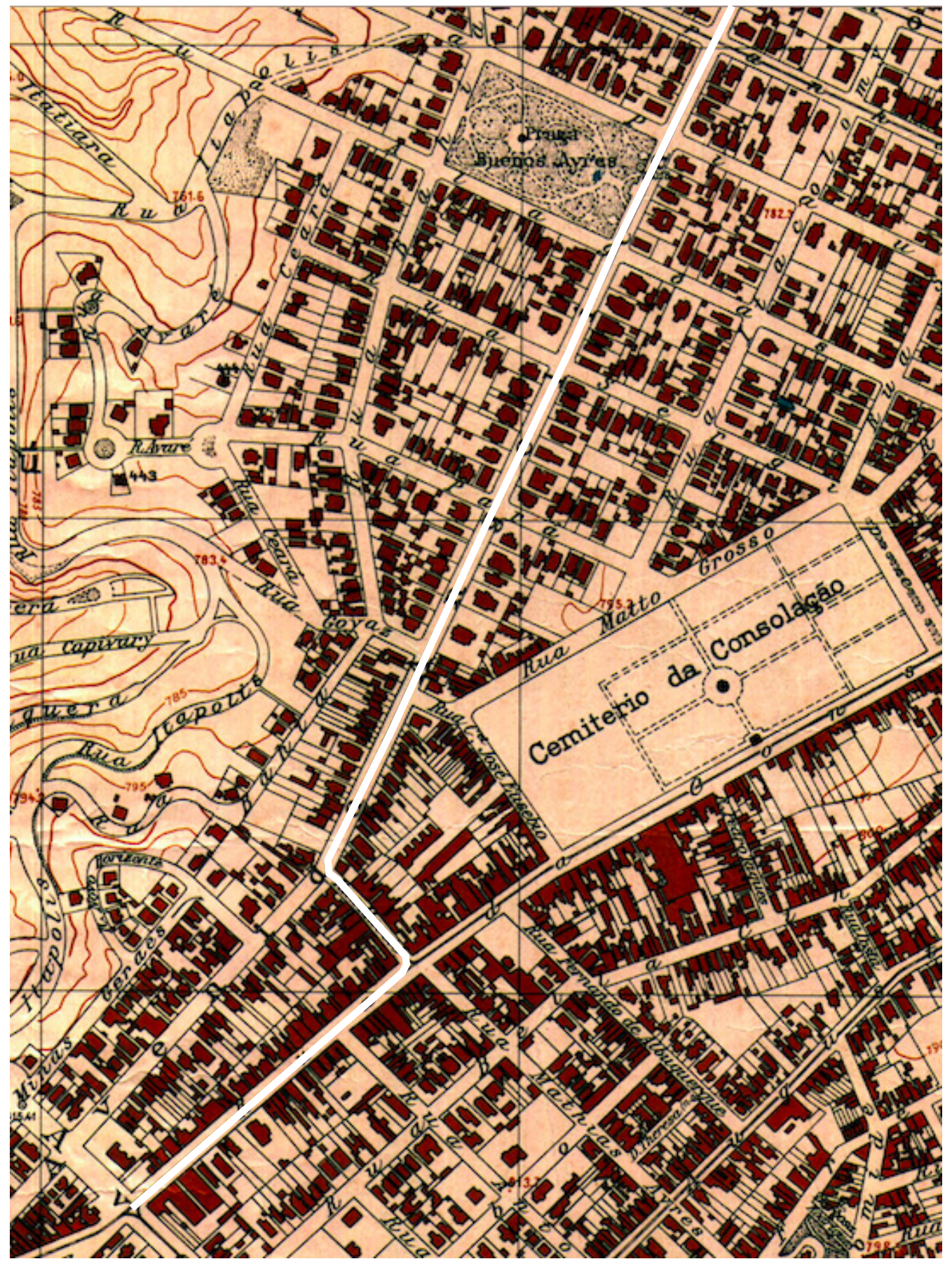

FIG. 29 - O percurso do bonde na Avenida Angélica. A curva da rua Maceió simboliza a fronteira entre os trechos superior e inferior da via. Fonte: SARA-Brasil, 1930. 


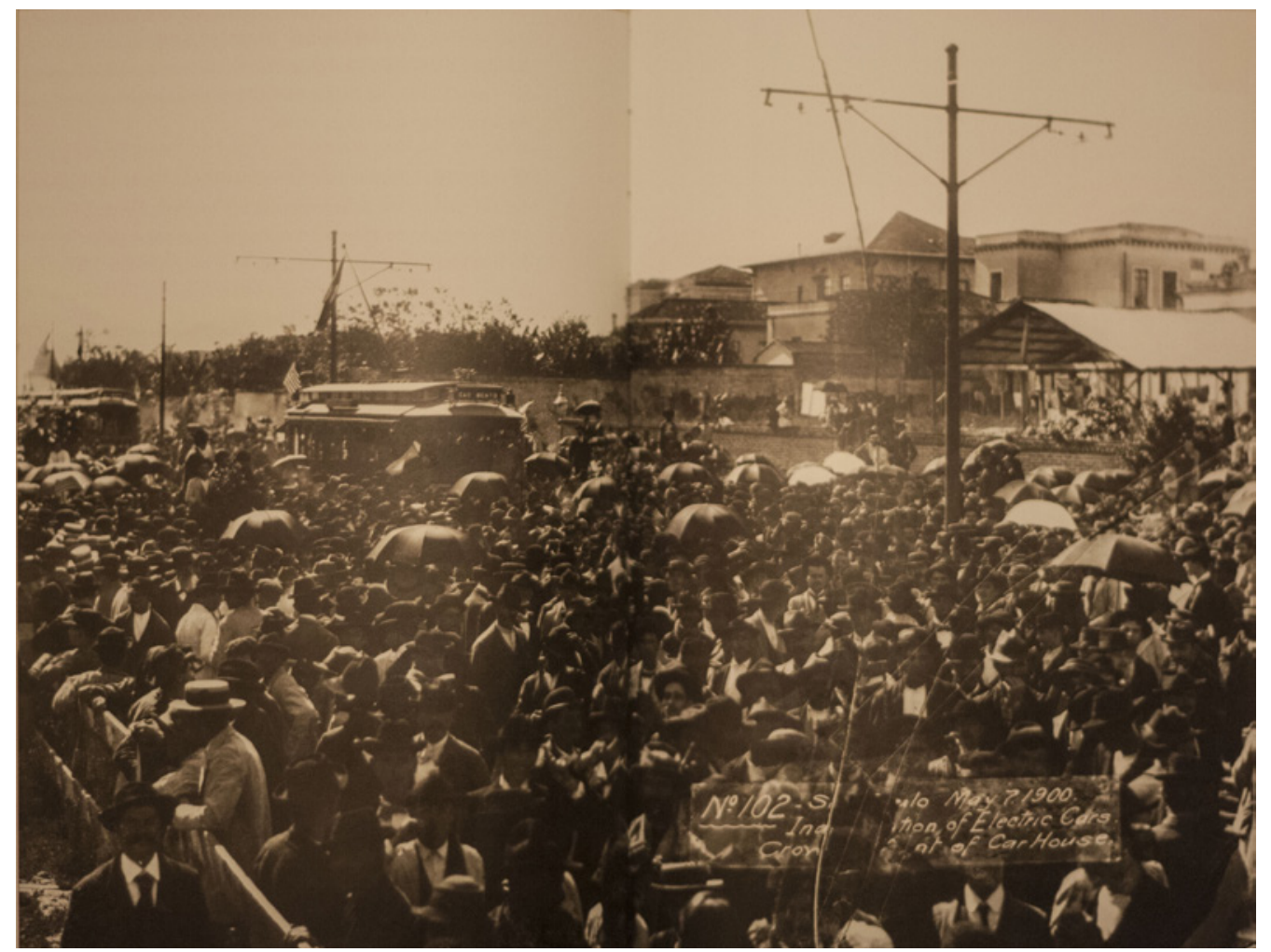

FIG. 30 - A multidão que recebia o bonde elétrico nas ruas de São Paulo, retratada pelas lentes de Guilherme Gaensly, 1900. Fonte: DIETRICH, 2001. 

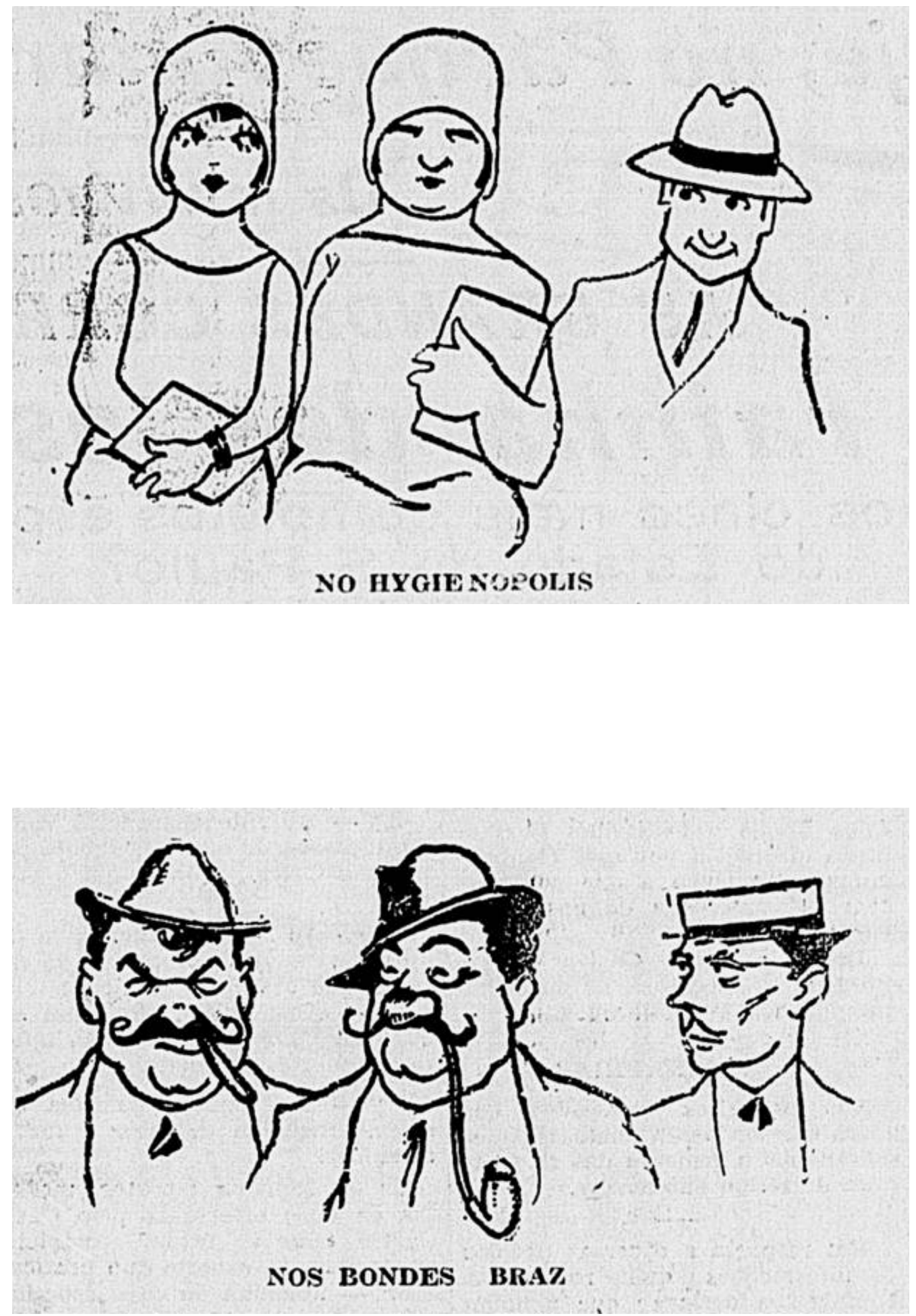

FIG. 31 - Ilustrações que acompanhavam a crônica "Os bondes também têm alma". Acima, o bonde de Higienópolis, abaixo, o do Brás. Fonte: Diário Nacional, "Os bondes também têm alma", 29 jan. 1928. 


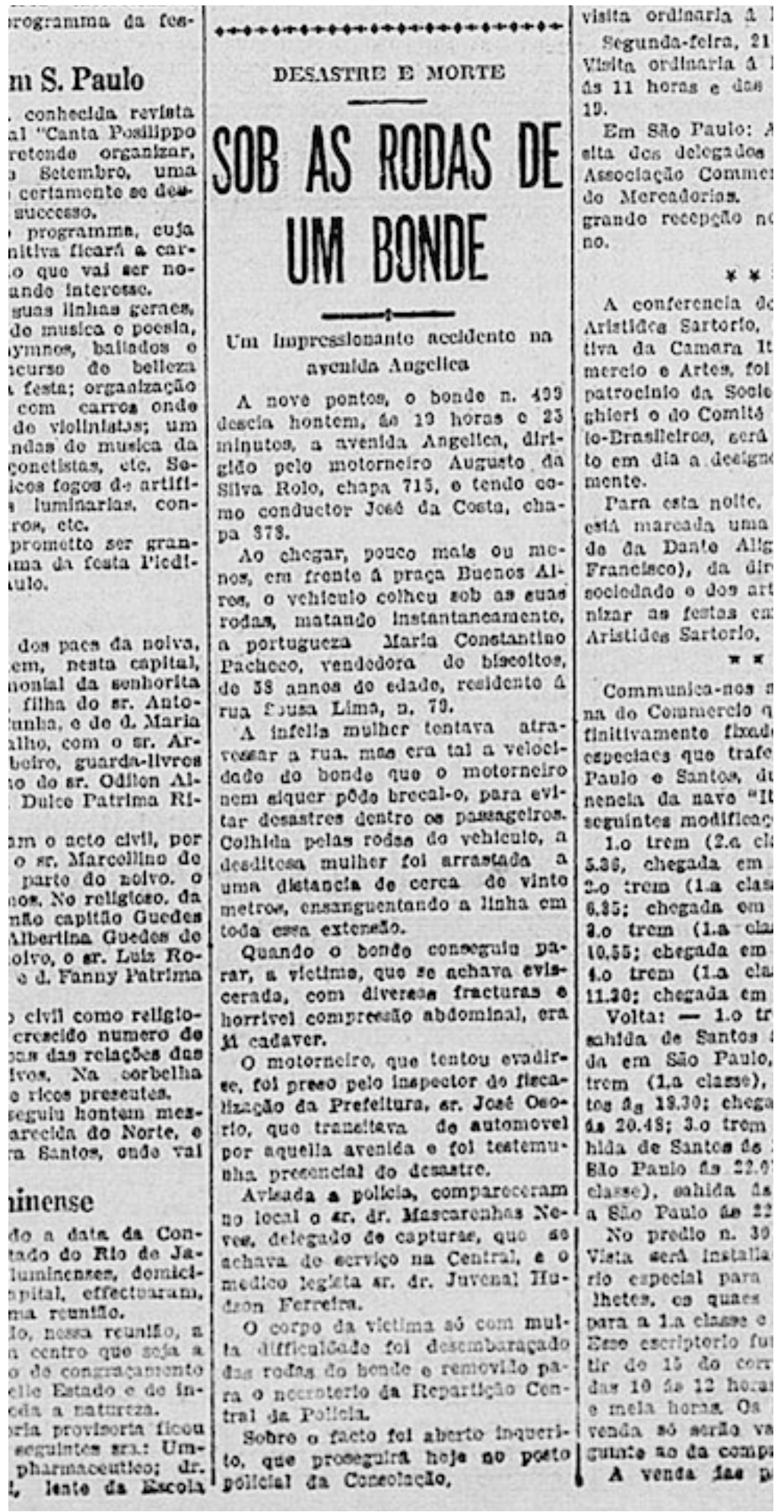

FIG. 32 - "Sob as rodas de um bonde - um impressionante acidente na Avenida Angélica”. Fonte: Correio Paulistano, 11 abr. 1924. 


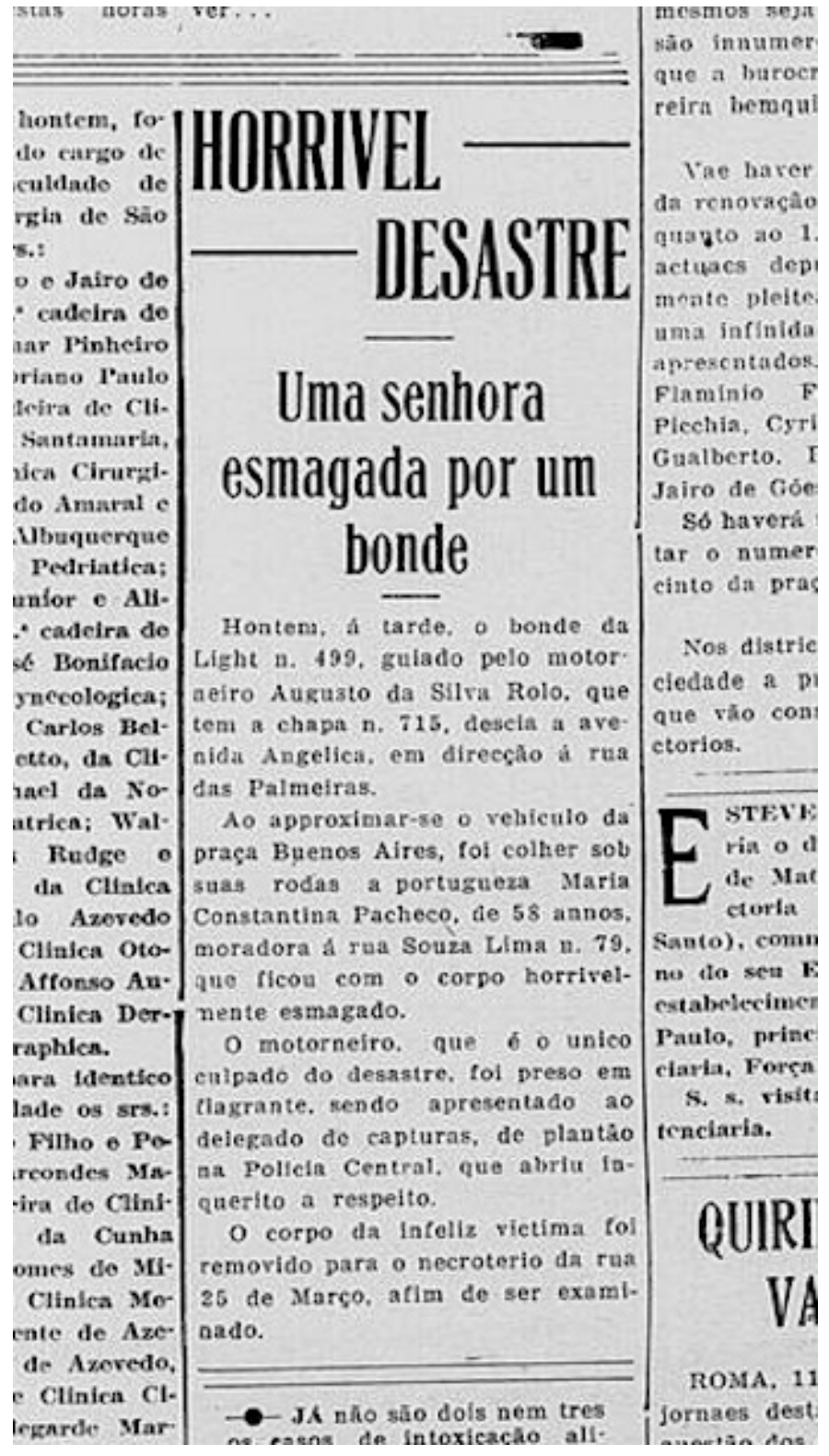

FIG. 33 - "Horrível desastre: uma senhora esmagada por um bonde" - Acidente na Avenida Angélica. Fonte: O Combate, 11 abr. 1924. 


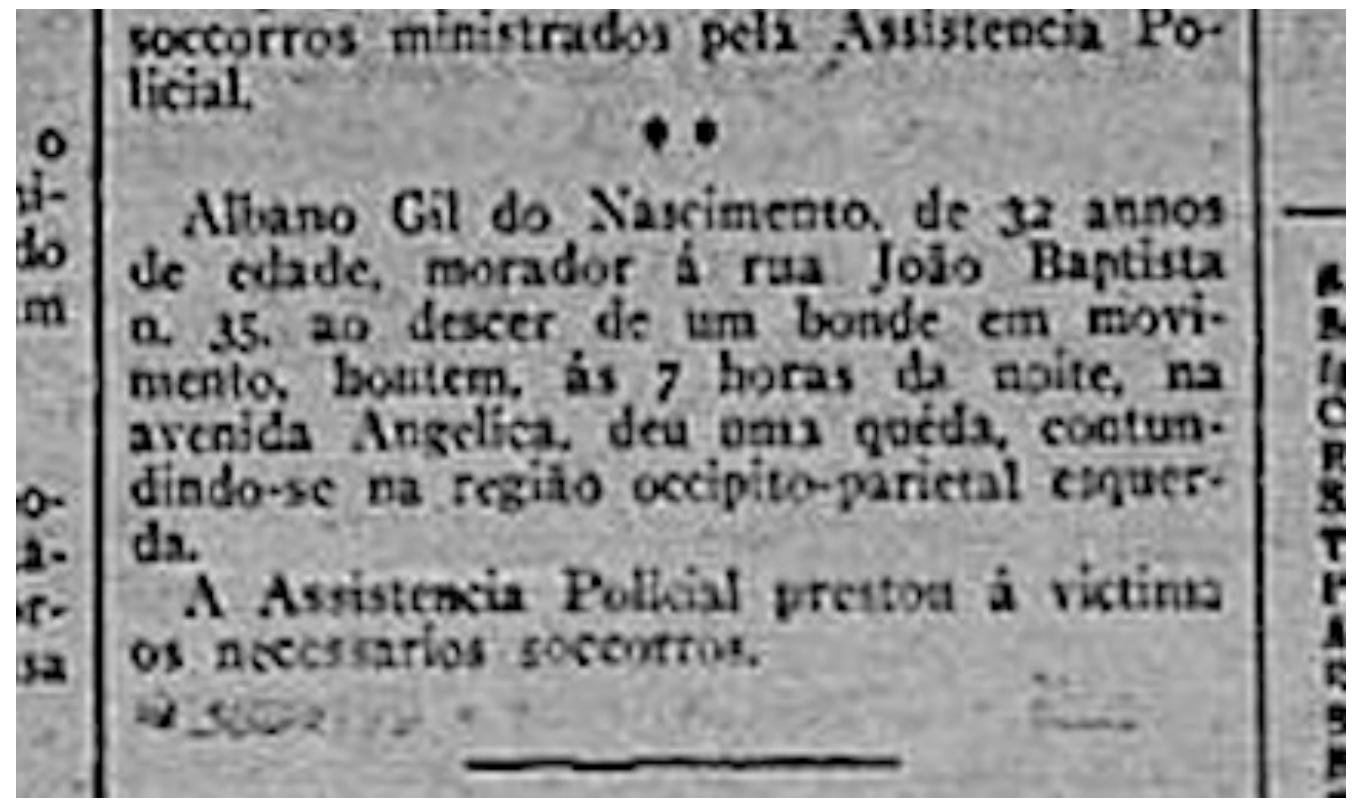

FIG. 34 - "Albano Gil (...) ao descer de um bonde em movimento, ontem, às 7 horas da noite, na Avenida Angélica, deu uma queda, contundindo-se na região occiptio-parietal esquerda". Fonte: Desastres e Ferimentos, Correio Paulistano, 11 mar. 1913.

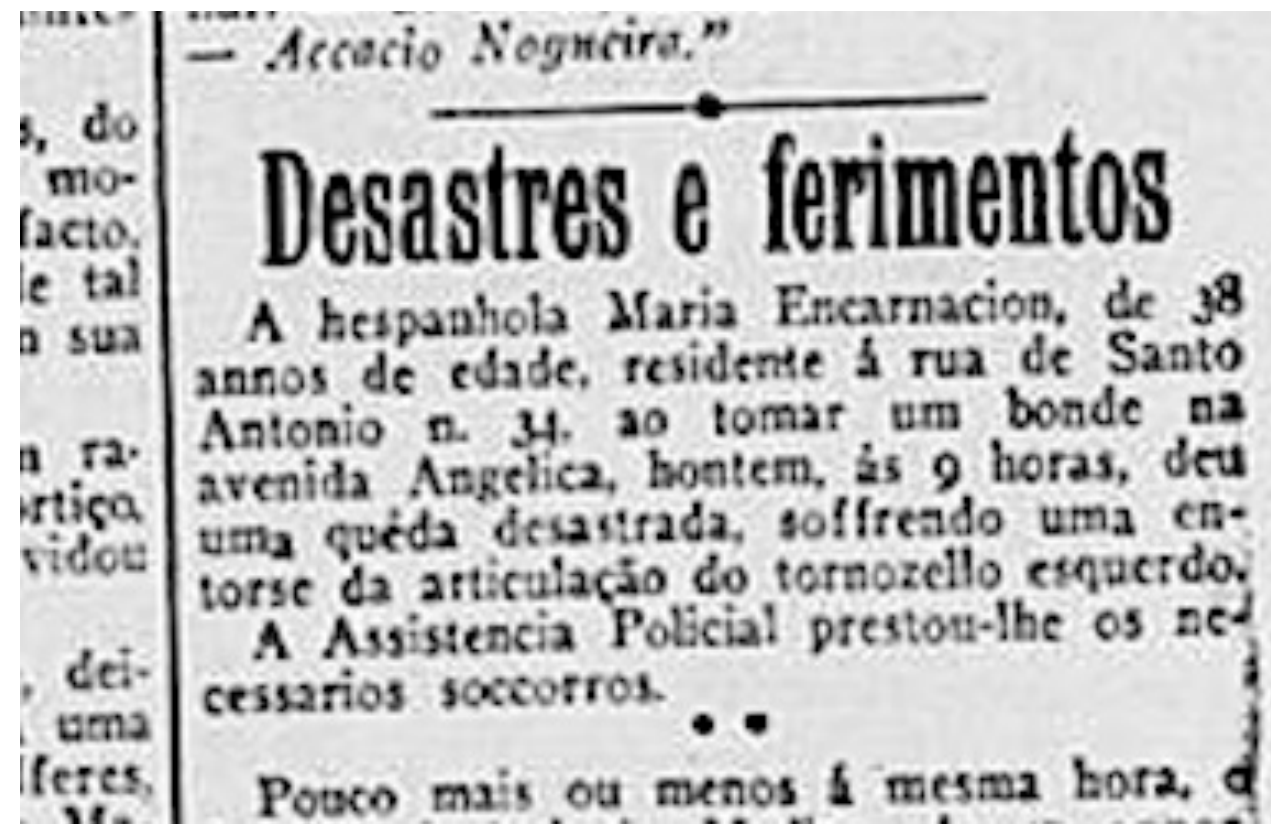

FIG. 35 - "A Espanhola Maria Encarnación (...) ao tomar um bonde na Avenida Angélica, ontem às 9 horas, deu uma queda desastrada, sofrendo uma entorse da articulação do tornozelo esquerdo". Fonte: Desastres e Ferimentos, Correio Paulistano, 23 set. 1914. 


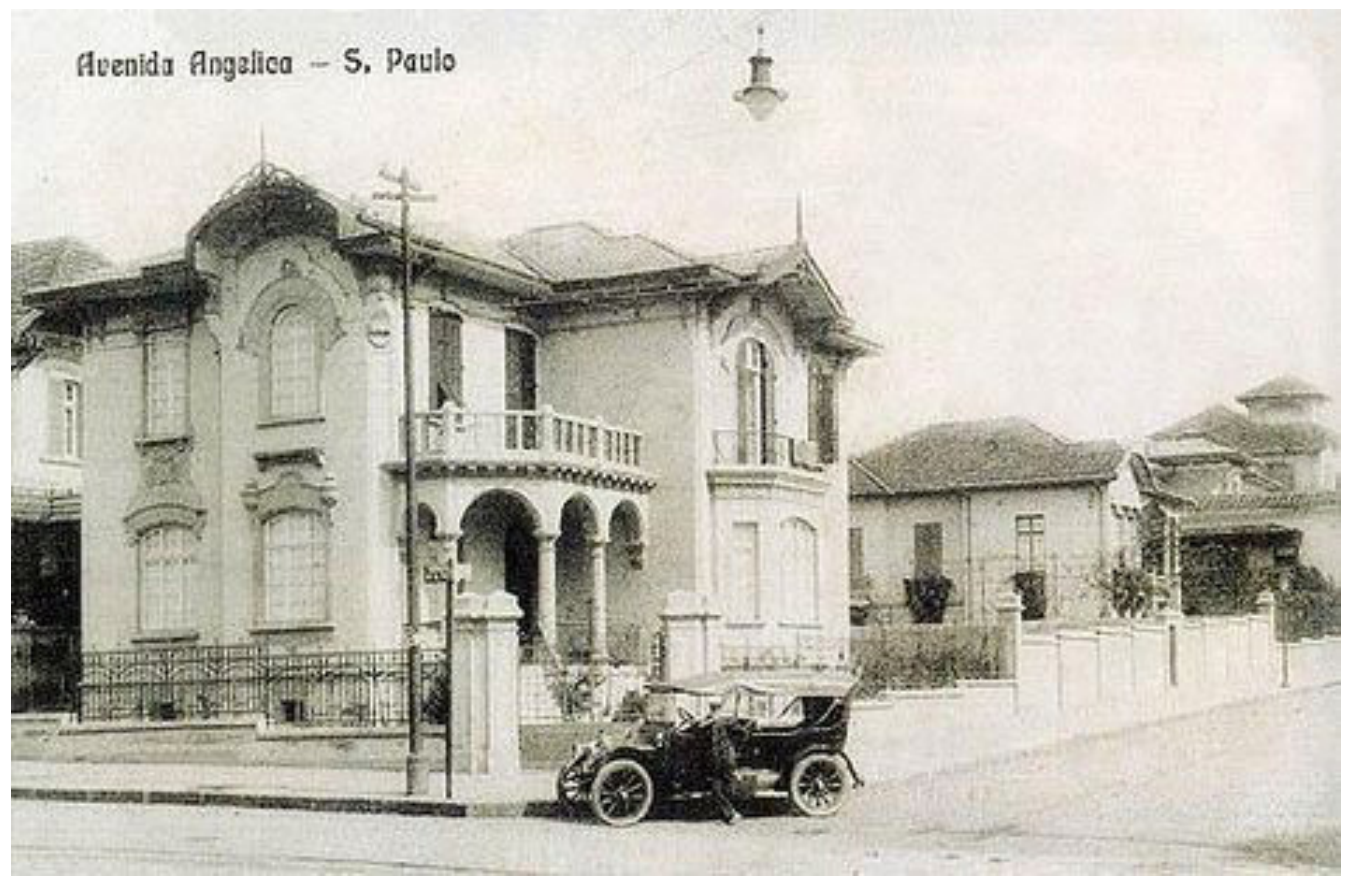

FIG. 36 - Os antigos e os novos donos da Avenida se encontram: carros e palacetes, os signos exibitivos de dois mundos que se entrecruzam. Cartão Postal da Avenida Angélica, de autor desconhecido, s/d. Fonte: https://br.pinterest.com/pin/466755948852076300/ (último acesso em fevereiro de 2017). 


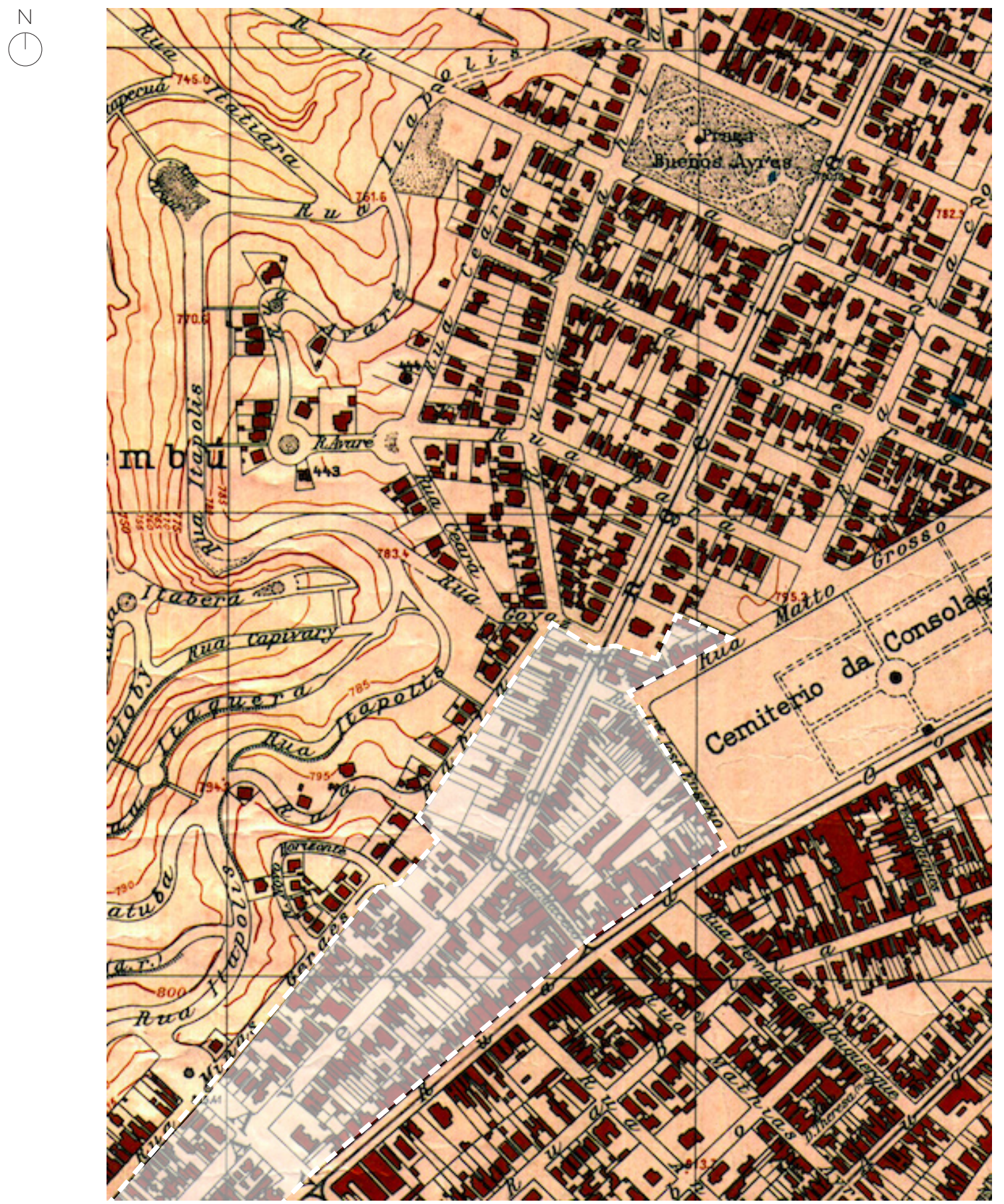

FIG. 37 - A fronteira no topo da Angélica. Fonte: SARA-Brasil (1930). 


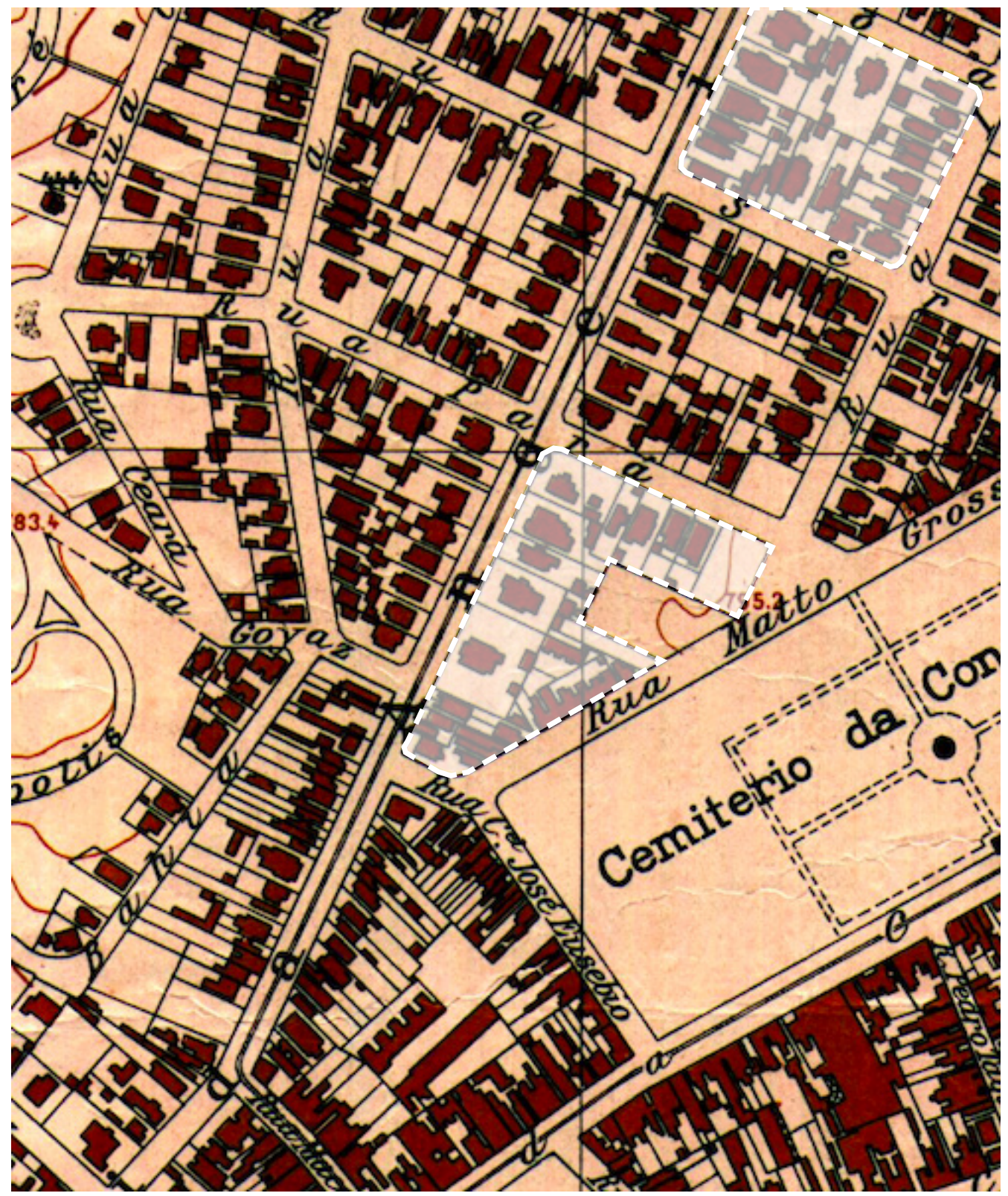

FIG. 37a - Pormenor da fronteira superior da Angélica. Fonte: SARA-Brasil (1930). 


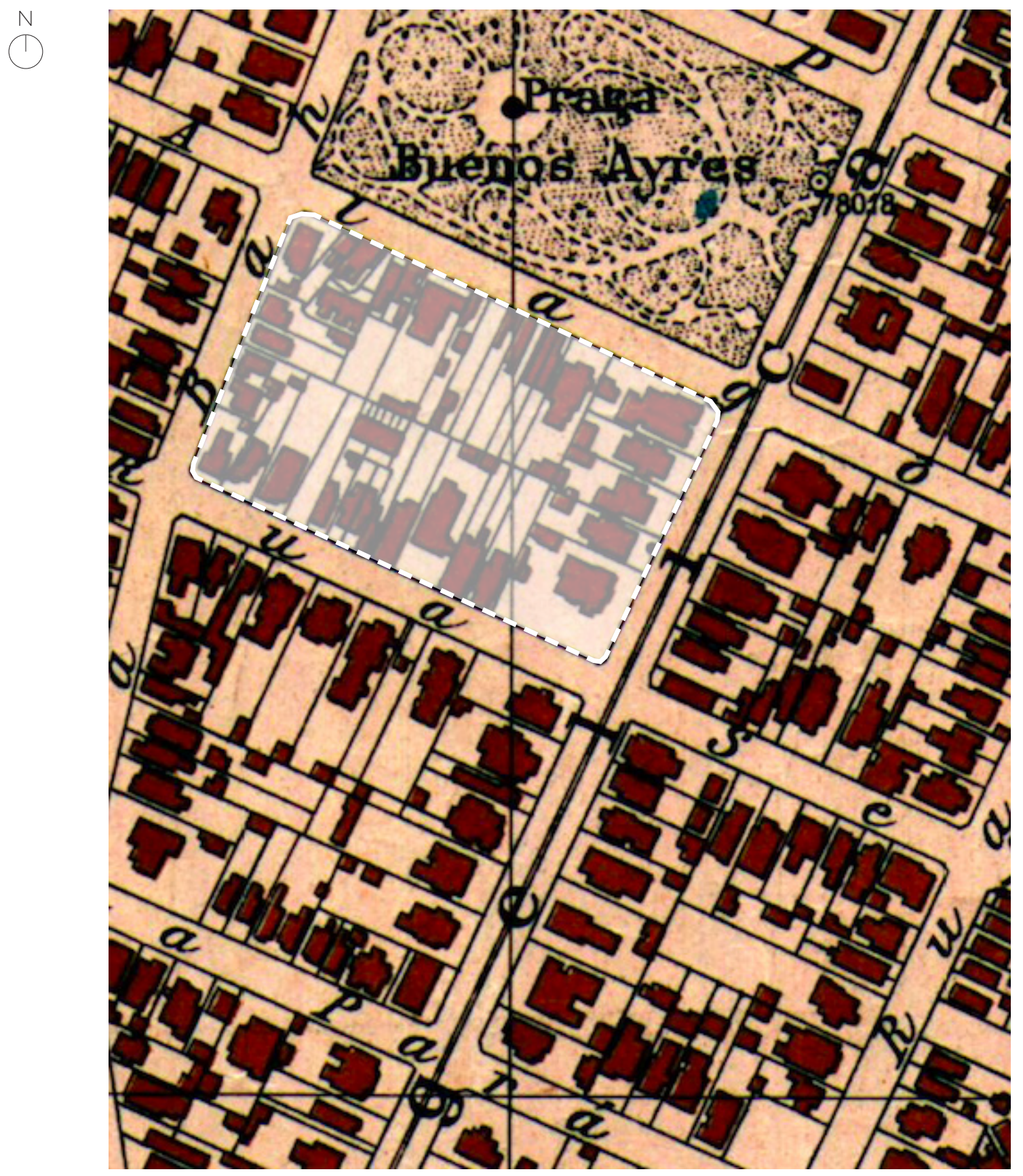

FIG. 38 - Fronteiras entre palacetes, residências médias e até uma pequena vila operária no quarteirão vizinho à Praça Buenos Aires. Fonte: SARA-Brasil (1930). 


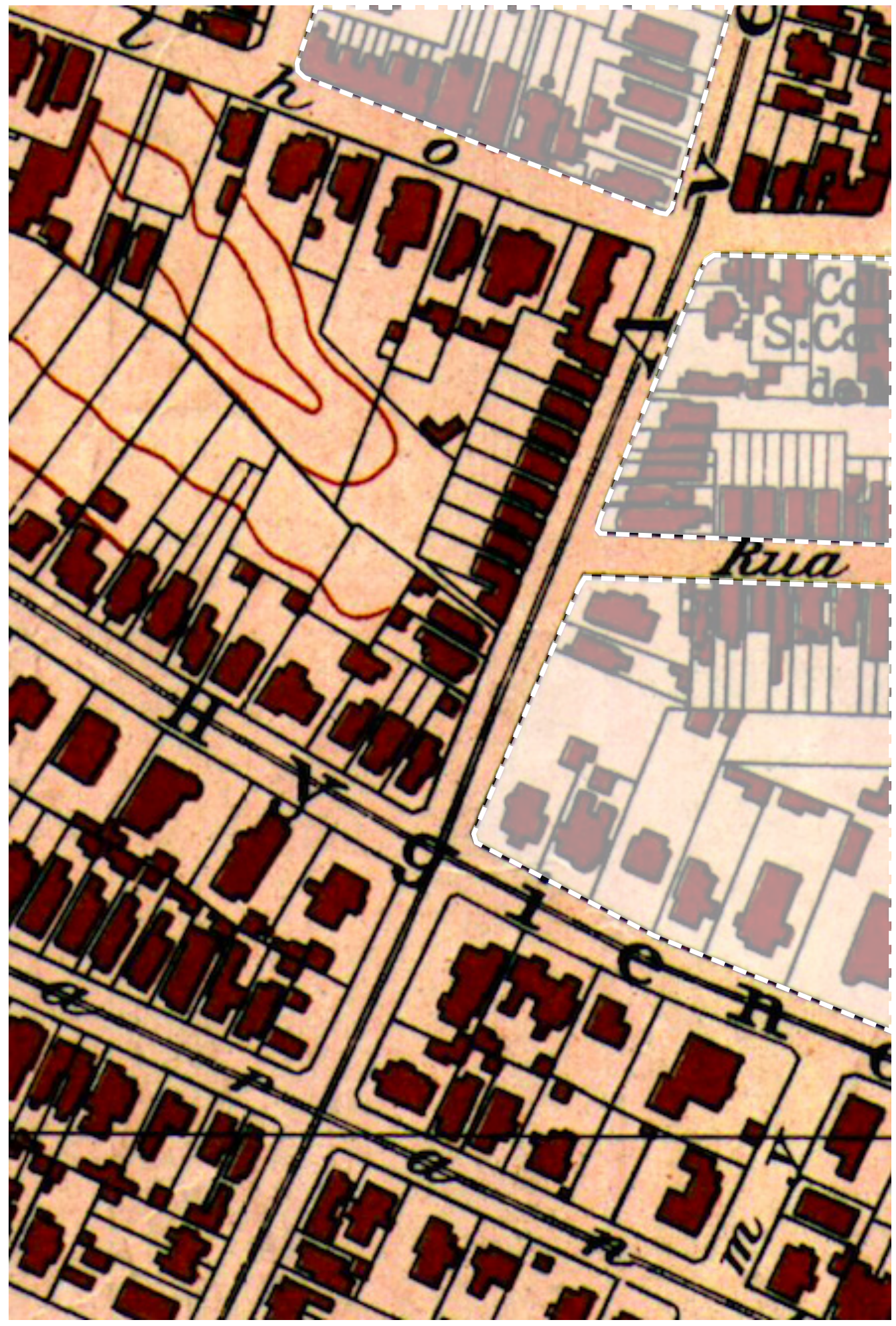

FIG. 39 - Fronteiras entre casas operárias, casas médias e palacetes entre a Avenida Higienópolis e a Rua Jaguaribe. Fonte: SARA-Brasil (1930). 


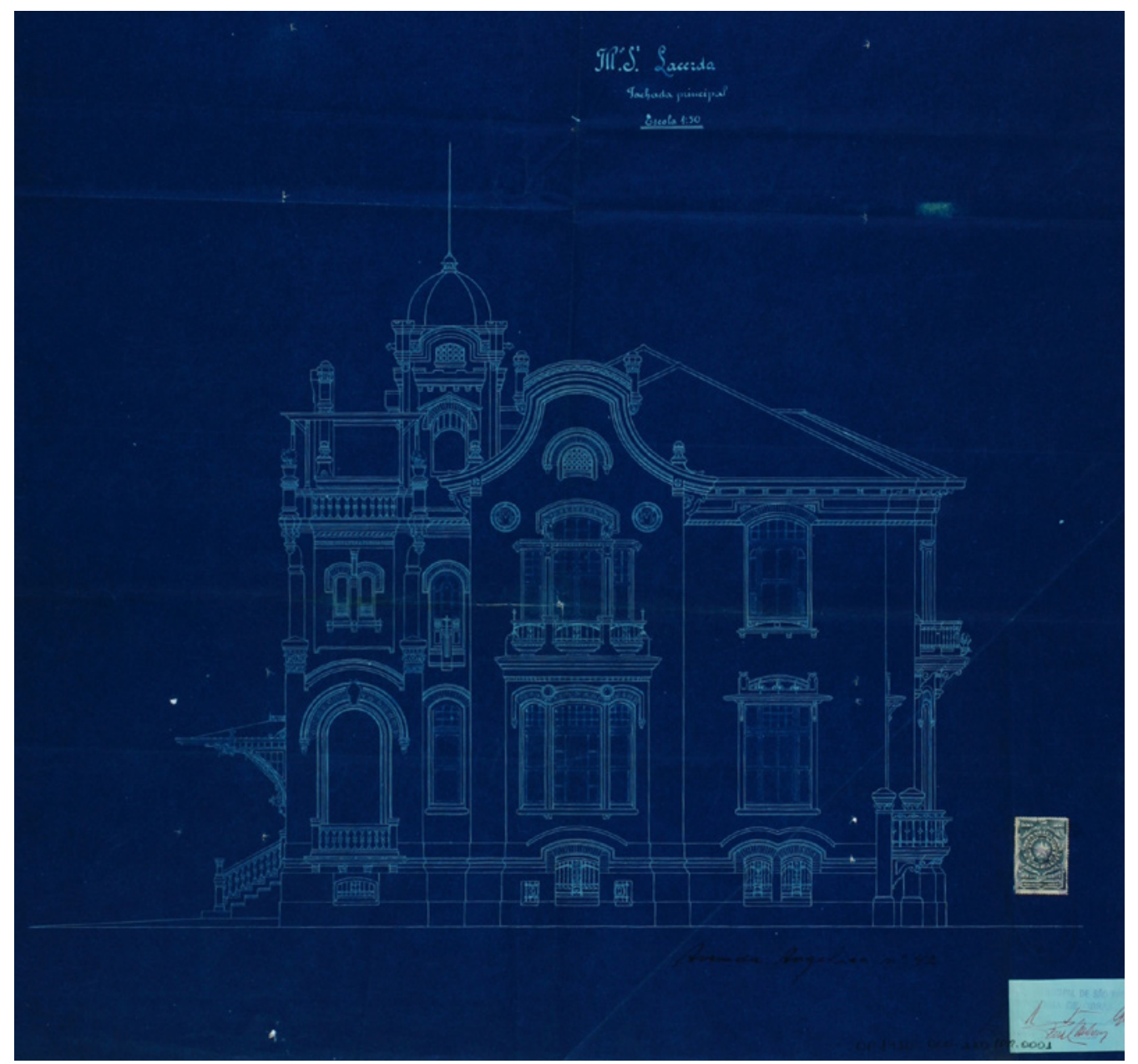

FIG. 40 - Elevação da residência de Sebastiana de Souza Queiroz. Fonte: Fundo de Obras Privadas do AHMSP, OP1910 - 000110. 


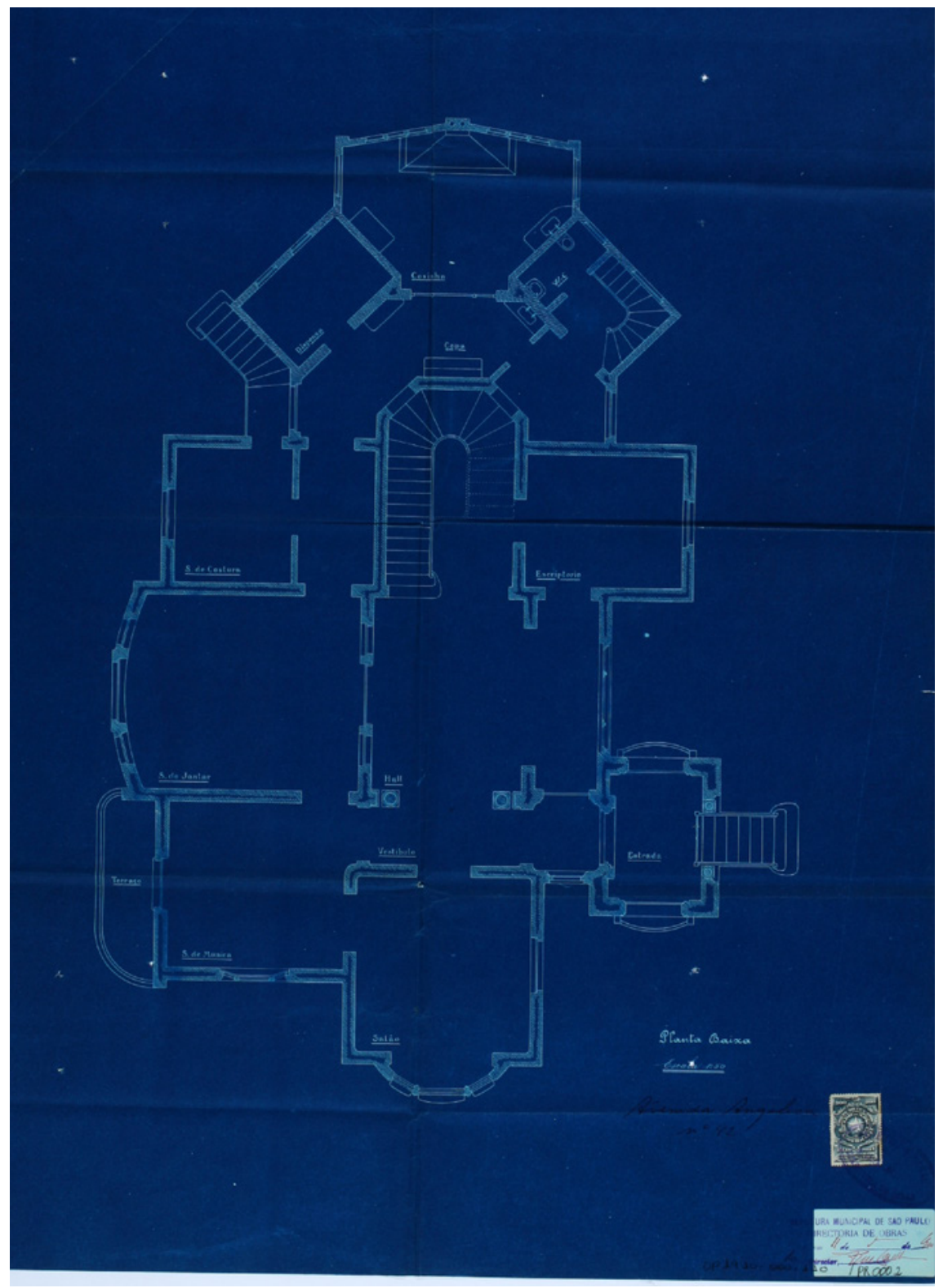

FIG. 41 - Planta do térreo da residência de Sebastiana de Souza Queiroz. Fonte: Fundo de Obras Privadas do AHMSP, OP1910 - 000110. 


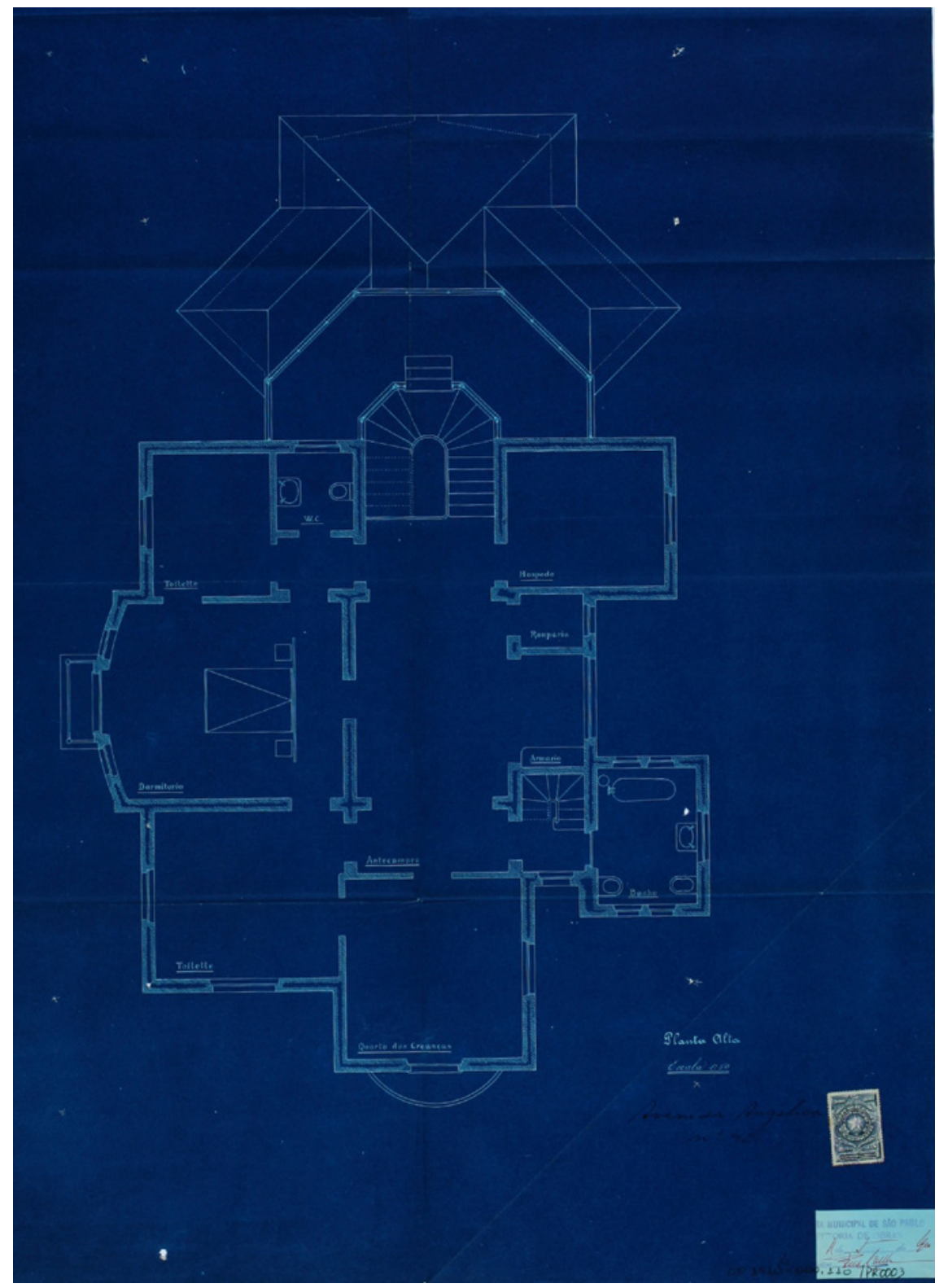

FIG. 42 - Planta do primeiro andar da residência de Sebastiana de Souza Queiroz. Fonte: Fundo de Obras Privadas do AHMSP, OP1910 - 000110. 


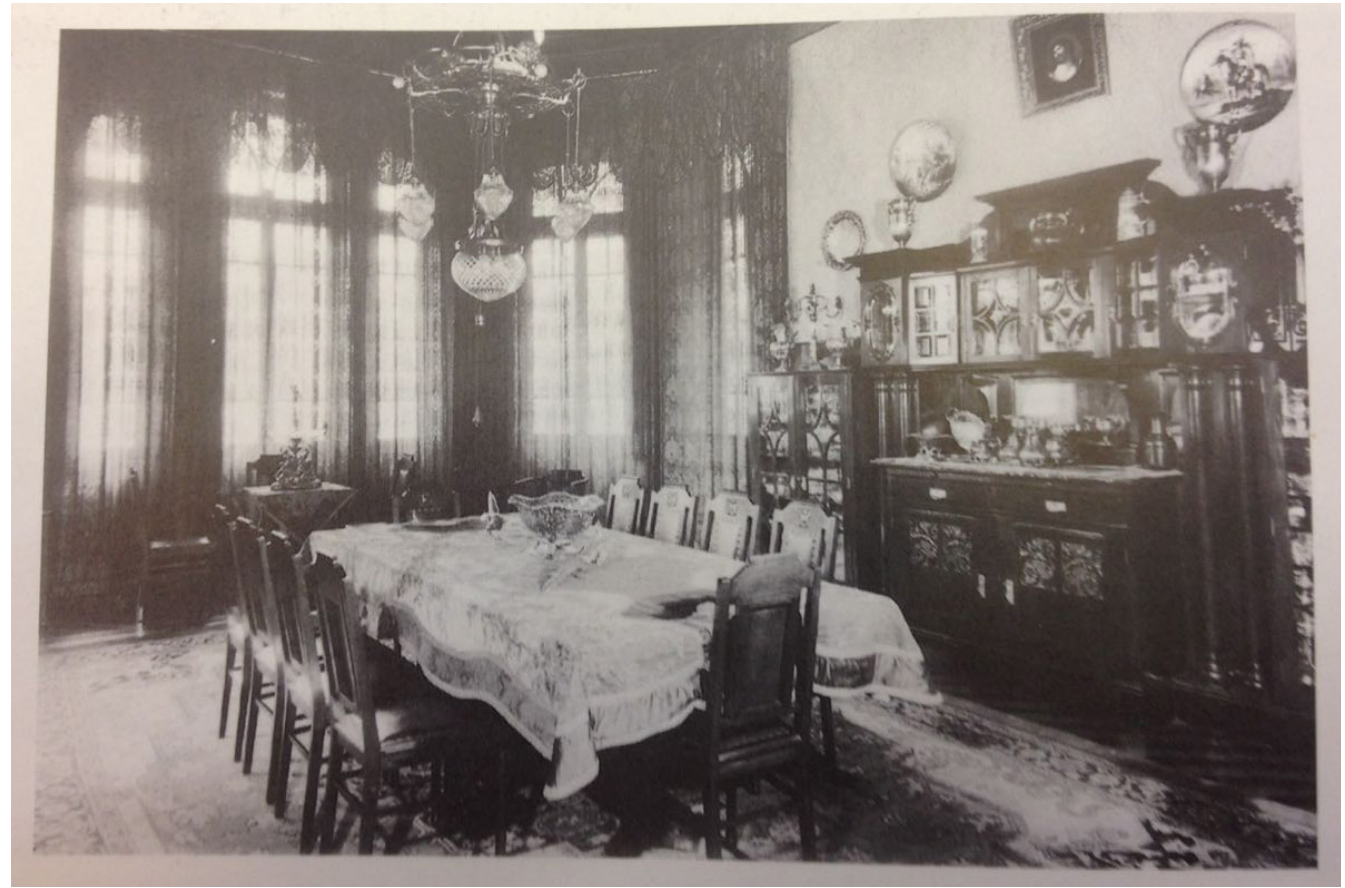

FIG. 43 - Sala de jantar da residência de José de Souza Queiroz, localizada na Rua Conselheiro Nébias, Campos Elíseos, s/d. Fonte: HOMEM, 1996.

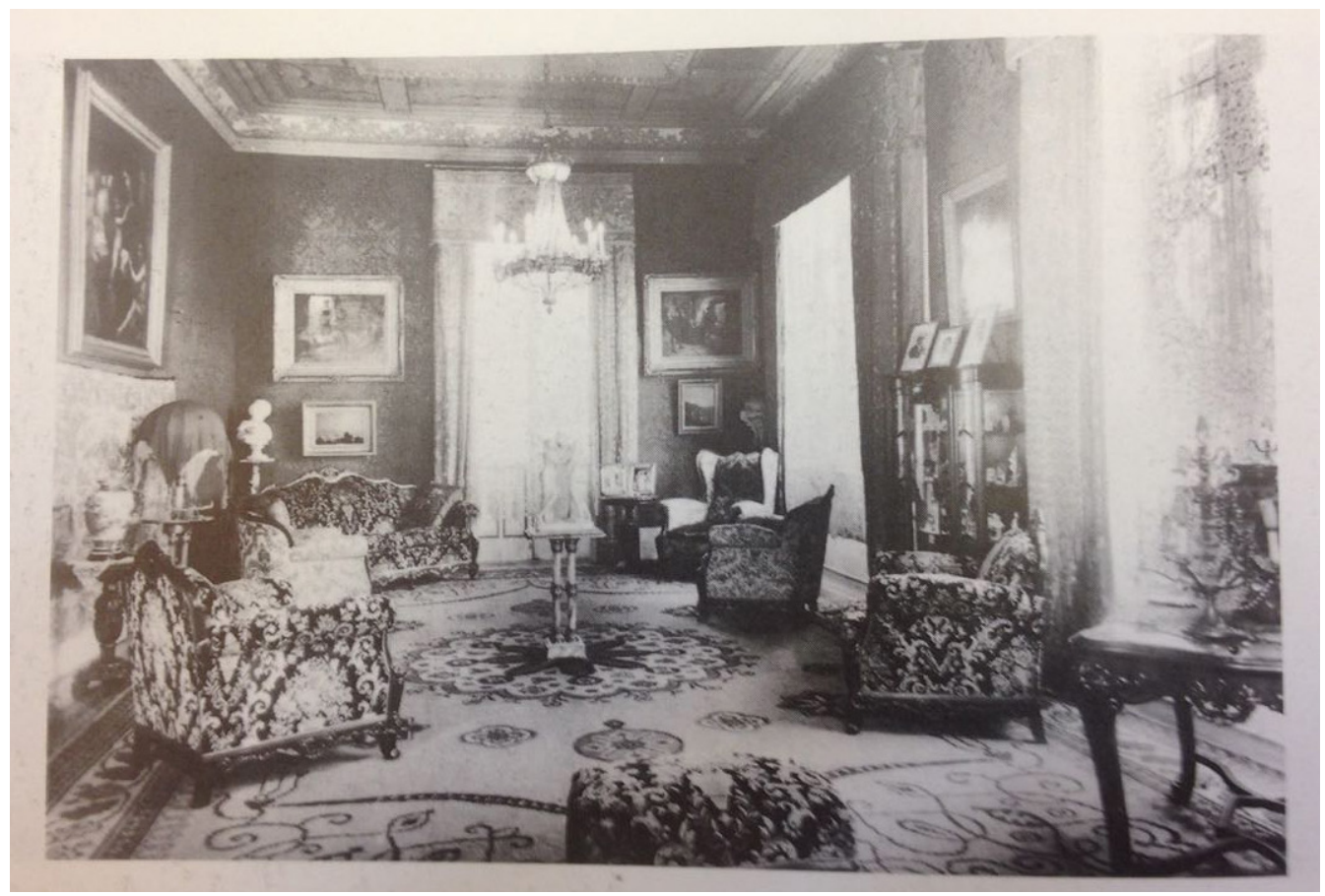

FIG. 44 - Sala de visitas da residência de José de Souza Queiroz, localizada na Rua Conselheiro Nébias, Campos Elíseos, s/d. Fonte: HOMEM, 1996. 


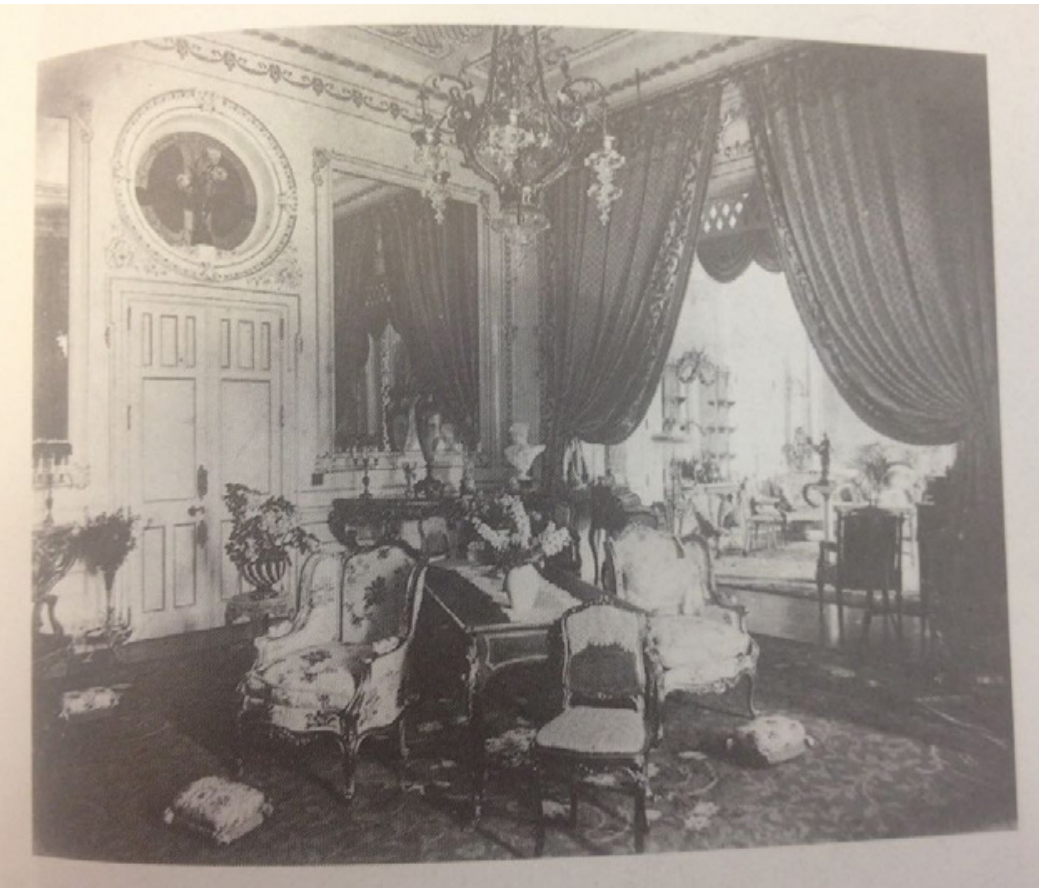

FIG. 45 - Sala "Maria Antonieta" da Vila Penteado, s/d. Fonte: Il brasil i gli Italiani apud HOMEM, 1996.

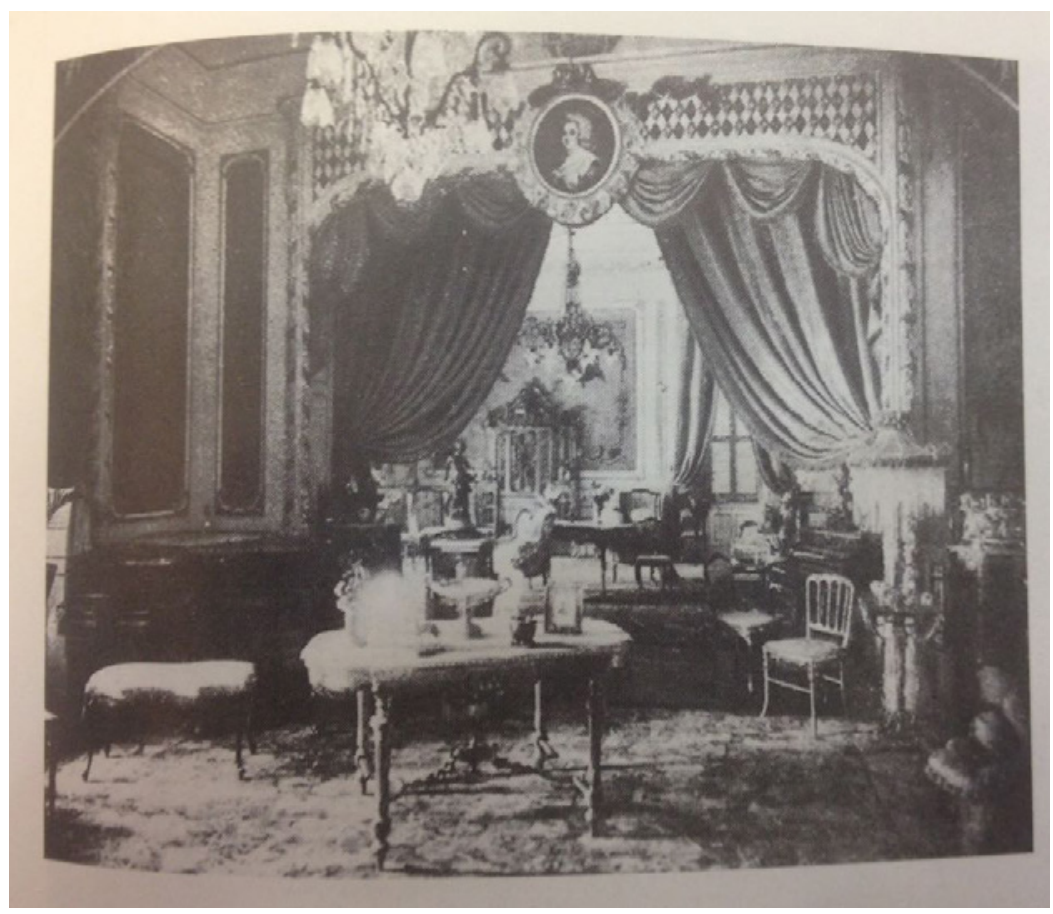

FIG. 46 - Sala "Luis XV" da Vila Penteado, s/d. Fonte: Il brasil i gli Italiani apud HOMEM, 1996. 


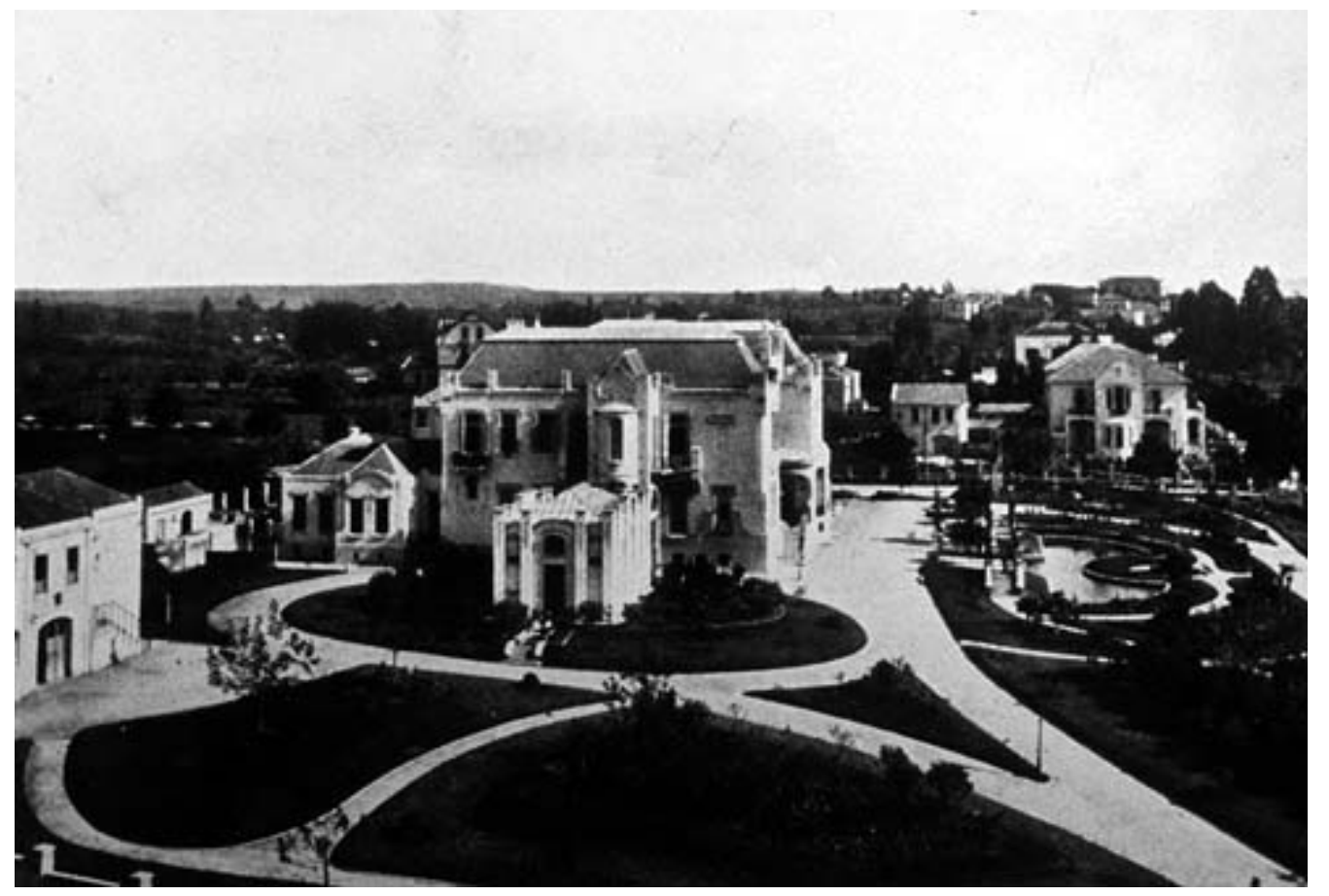

FIG. 47 - Vila Penteado, c. 1905. A pujança da edificação provém em grande parte de sua implantação no centro de um terreno inclinado, como se fosse, literalmente, um pedestal. Fonte: Il brasil i gli Italiani apud HOMEM, 1996.

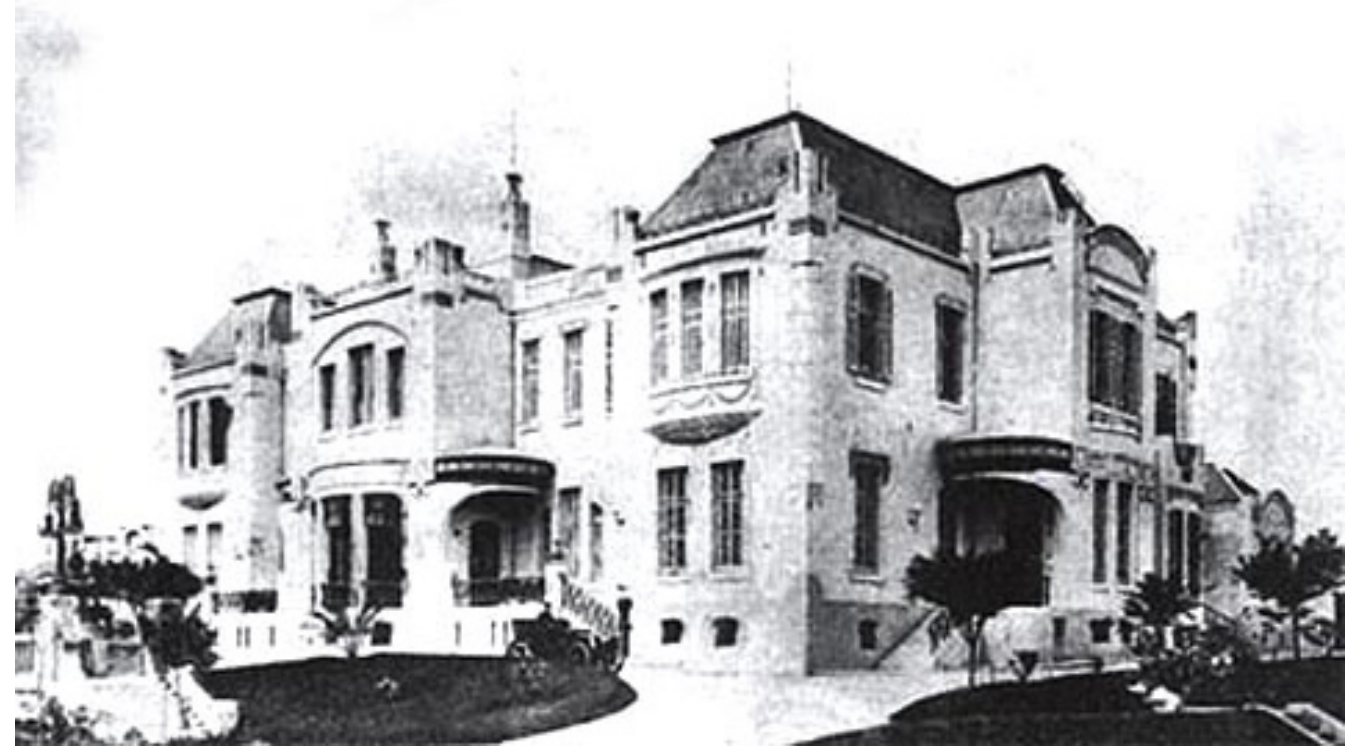

FIG. 48 - Vila Penteado, c. 1905. Notar que, apesar de ter como estilo predominante o artnoveau, o volume da residência tem como base fundamental o solene equilíbrio compositivo do neoclassicismo: volume predominantemente horizontal, rigorosamente simétrico, demarcação acentuada do centro e arremates nas laterais. Fonte: Il brasil i gli Italiani apud HOMEM, 1996. 


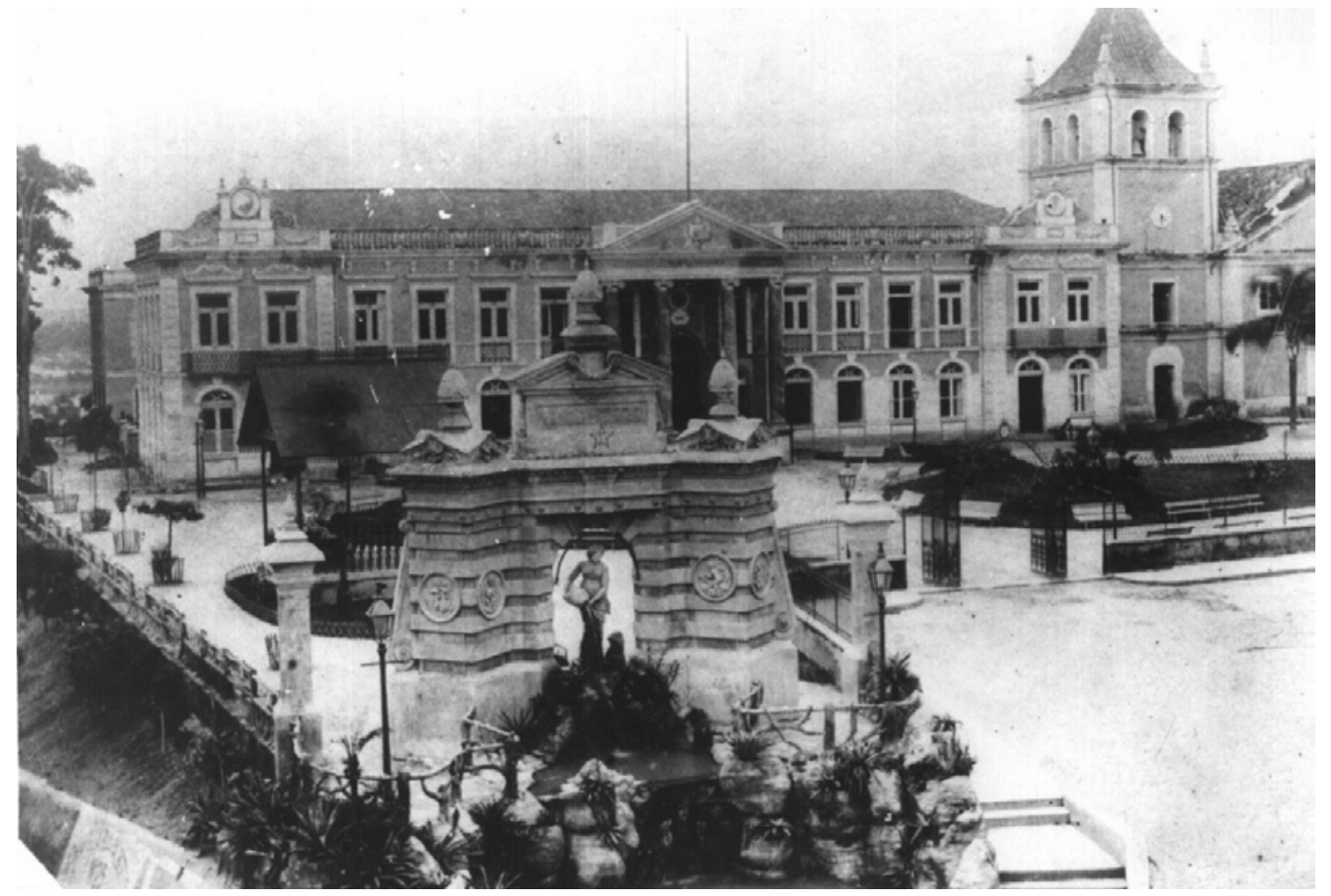

FIG. 49 - Palácio do Governo, 1887. Apesar do neoclassicismo do Palácio ser mais pujante do que a expressão da Vila Penteado, sua implantação, sem dúvidas, era menos magnânima. Foto de Militão Augusto de Azevedo. Fonte: Repositório Digital do AHMSP.

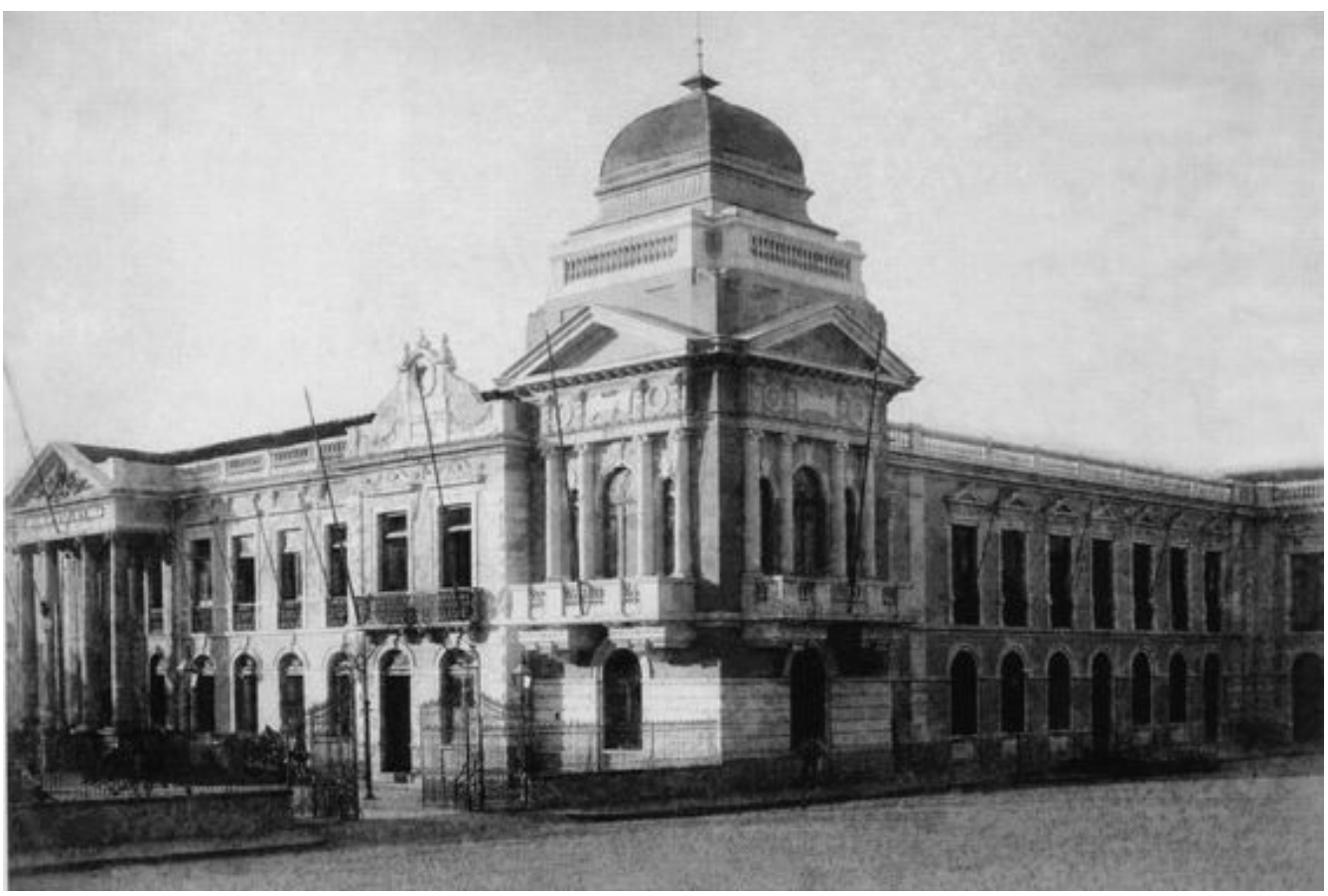

FIG. 50 - Palácio do Governo, c. 1900. Foto de Guilherme Gaensly. Fonte: Repositório Digital do AHMSP. 


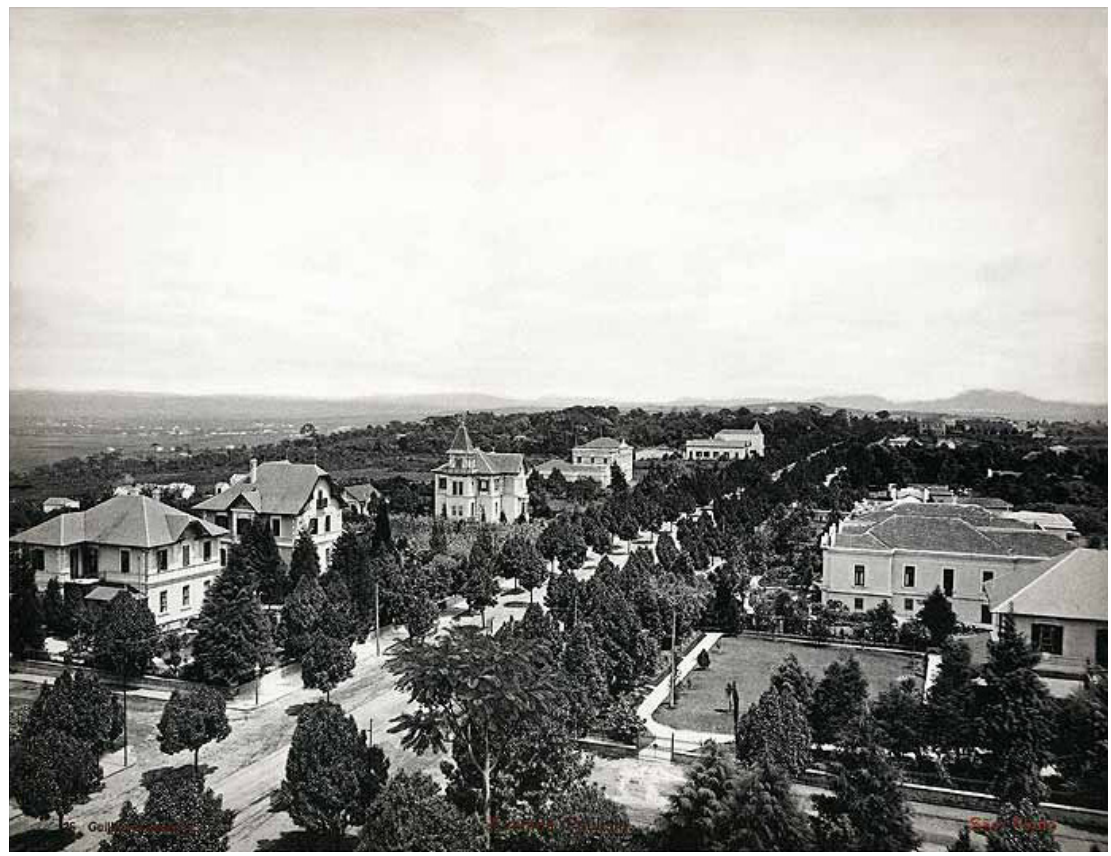

FIG. 51 - Avenida Paulista, c. 1900. Foto de Guilherme Gaensly, onde podemos observar o modelo visual que guiava o ideal da "passarela das elites" na Angélica. Fonte: Repositório Digital do AHMSP.

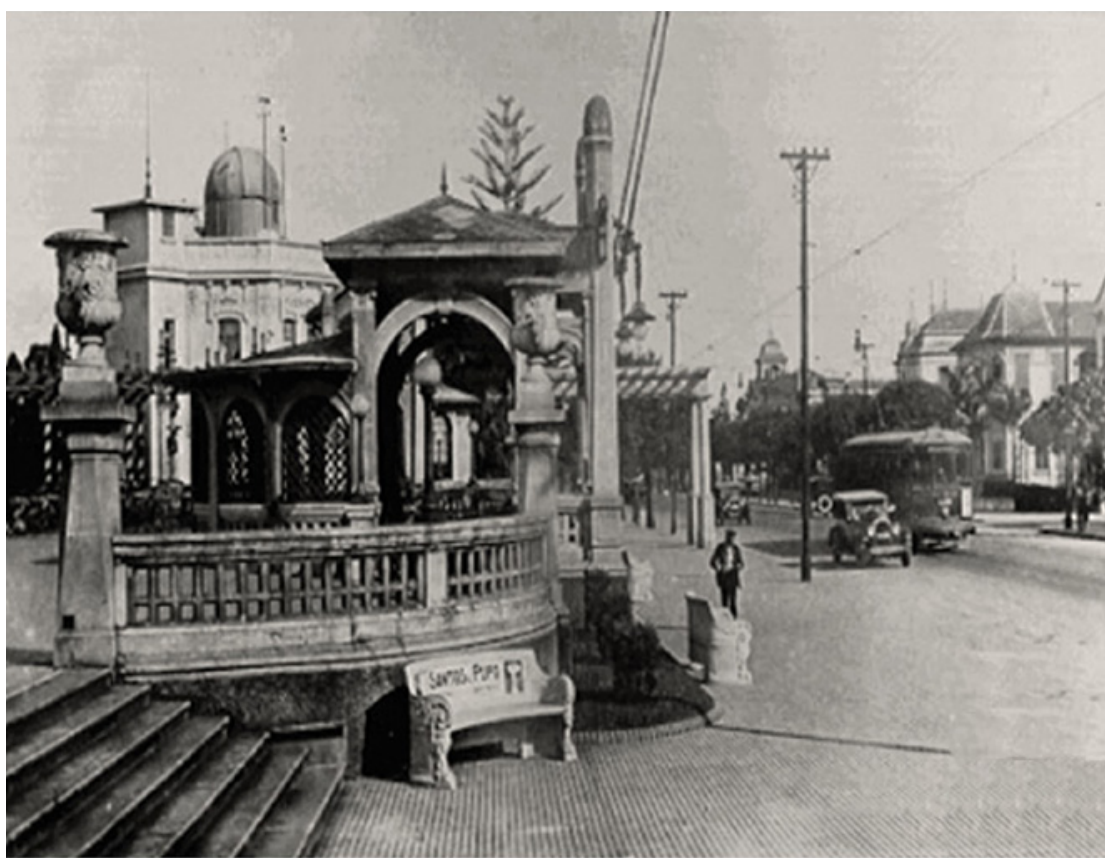

FIG. 51a - Avenida Paulista vista do Boulevard do Trianon, c. 1920. Foto de autor desconhecido, onde também podemos observar o modelo visual que guiava o ideal da "passarela das elites" na Angélica. Fonte: Repositório Digital do AHMSP. 


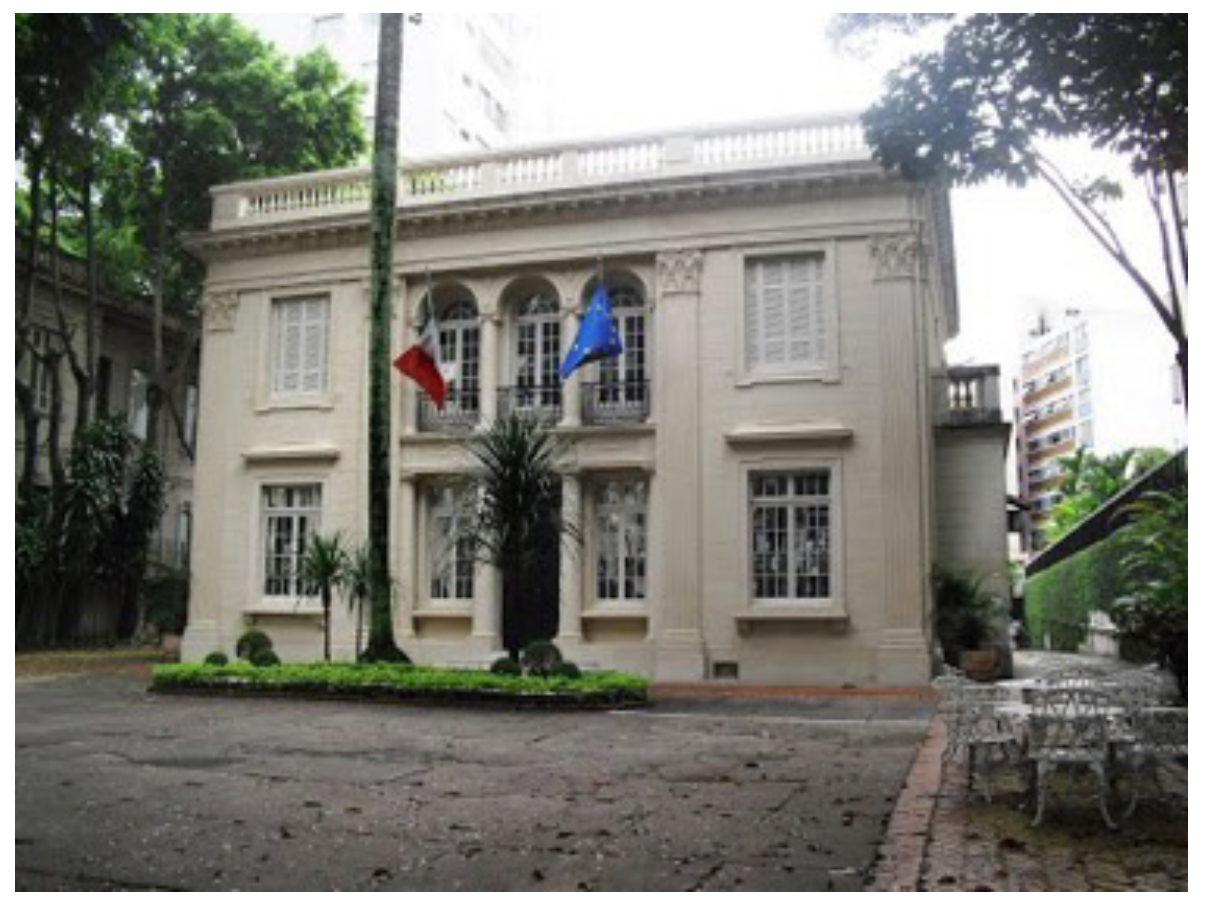

FIG. 52 - Residência de Oscar Rodrigues Alves, hoje Consulado Geral da Itália, na Avenida Higienópolis, quase esquina com a Avenida Angélica, s/d. Fonte: http://www. panoramio.com/photo/132263477 (último acesso em fevereiro de 2017).

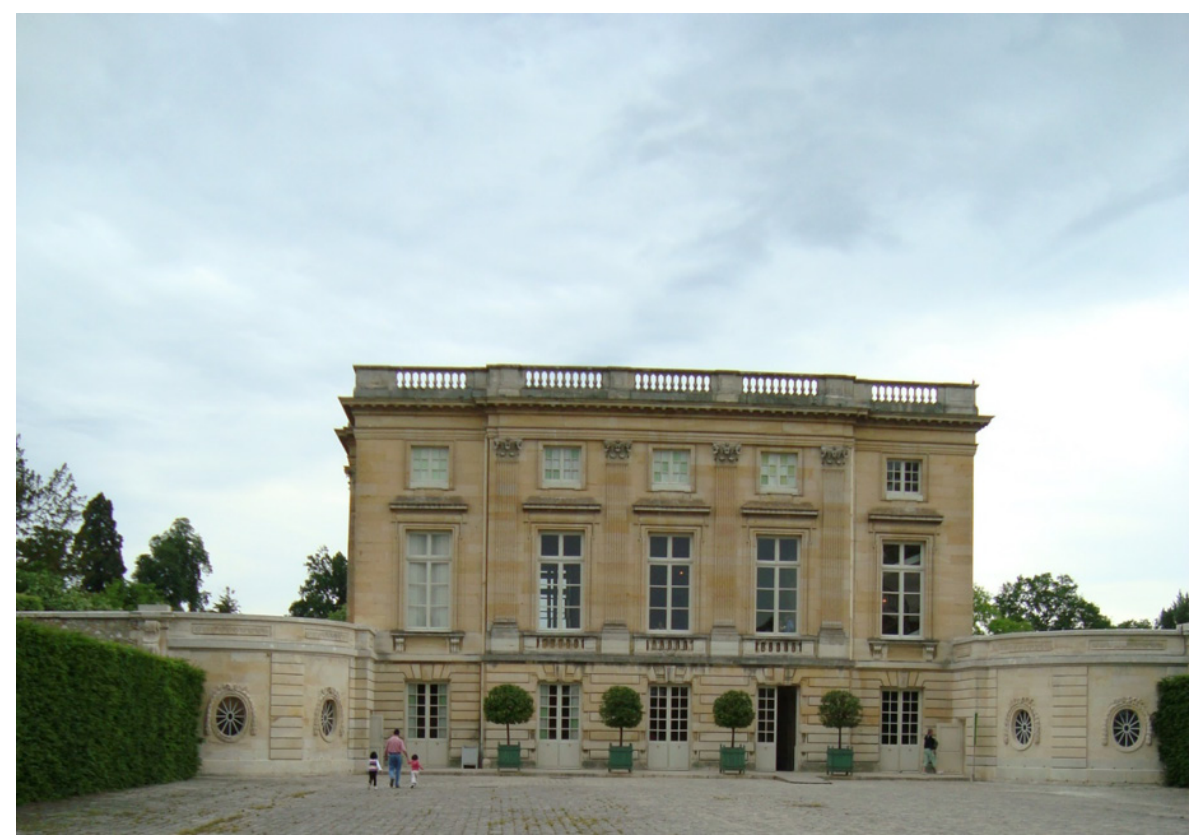

FIG. 53 - Petit Trianon, edificado em Versalhes em meados do século XVIII por Luís XV. Fonte: https://pt.wikipedia.org/wiki/Petit_Trianon\#/media/File:Petit_Trianon.JPG (último acesso em fevereiro de 2017). 


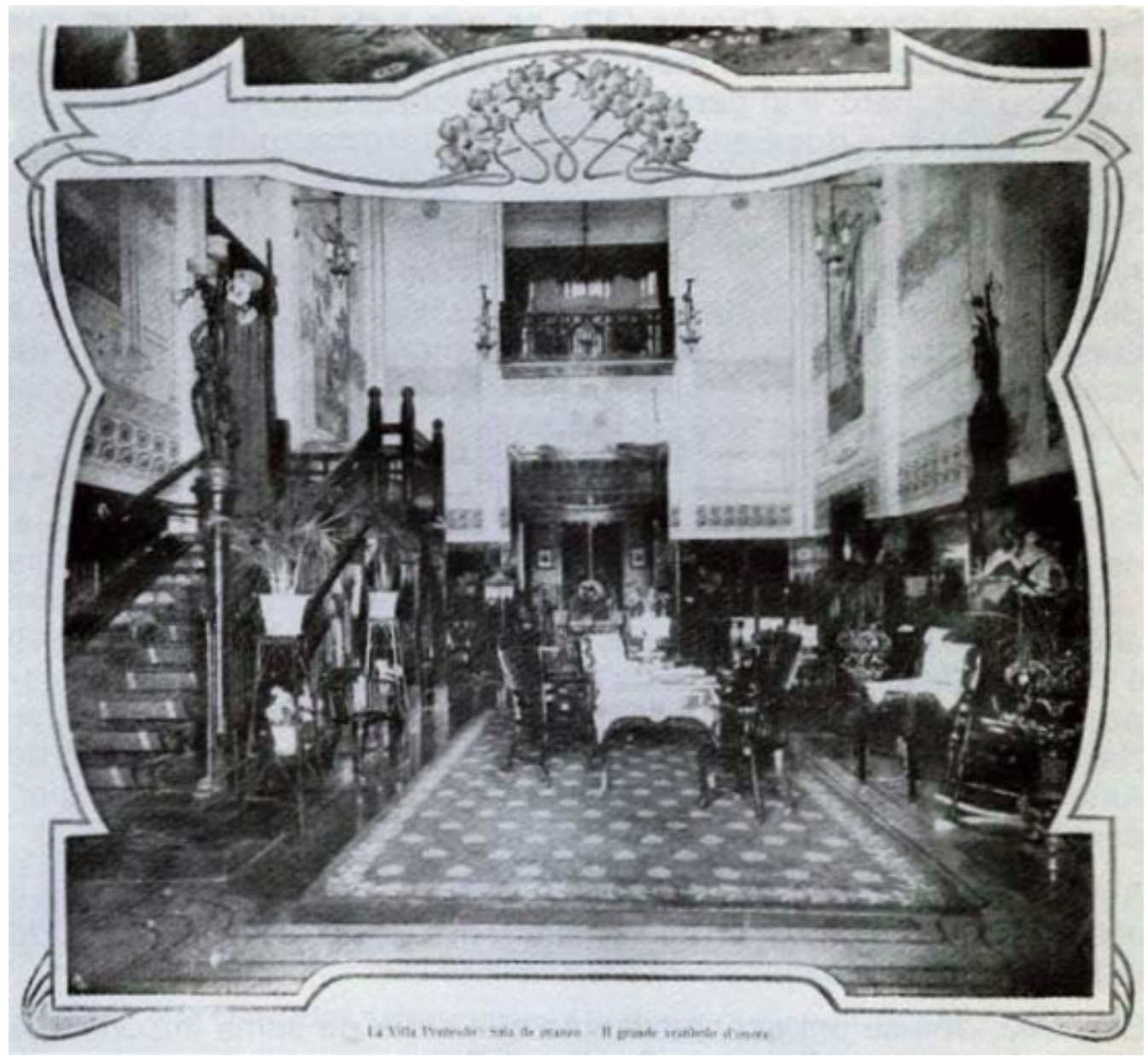

FIG. 54 - Escadaria do salão principal da Vila Penteado, c. 1900. Fonte: Il brasil i gli Italiani apud HOMEM, 1996. 


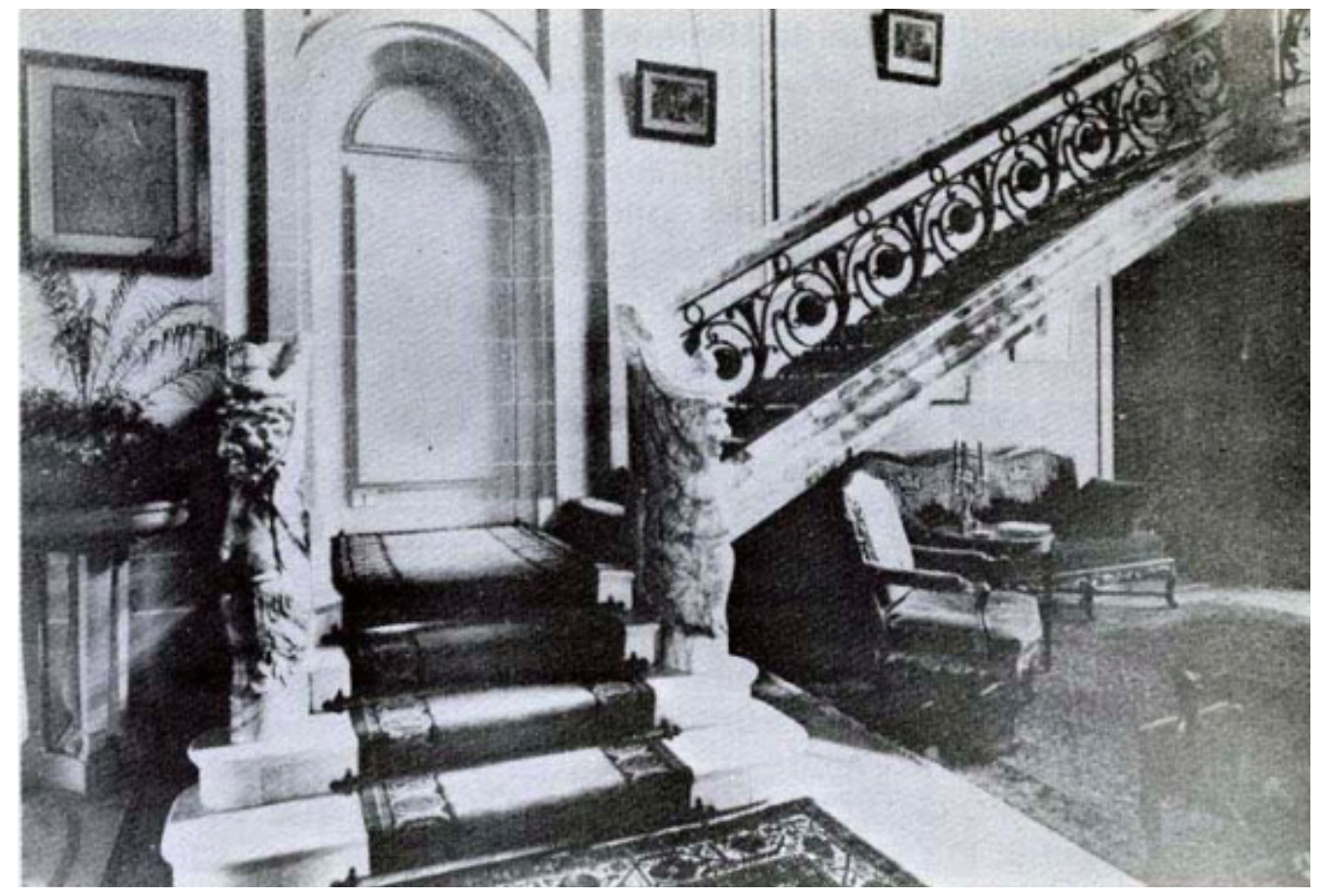

FIG. 55 - Escadaria do salão principal da residência de Stella e Martinho da Silva Prado. Fonte: HOMEM, 1996. 


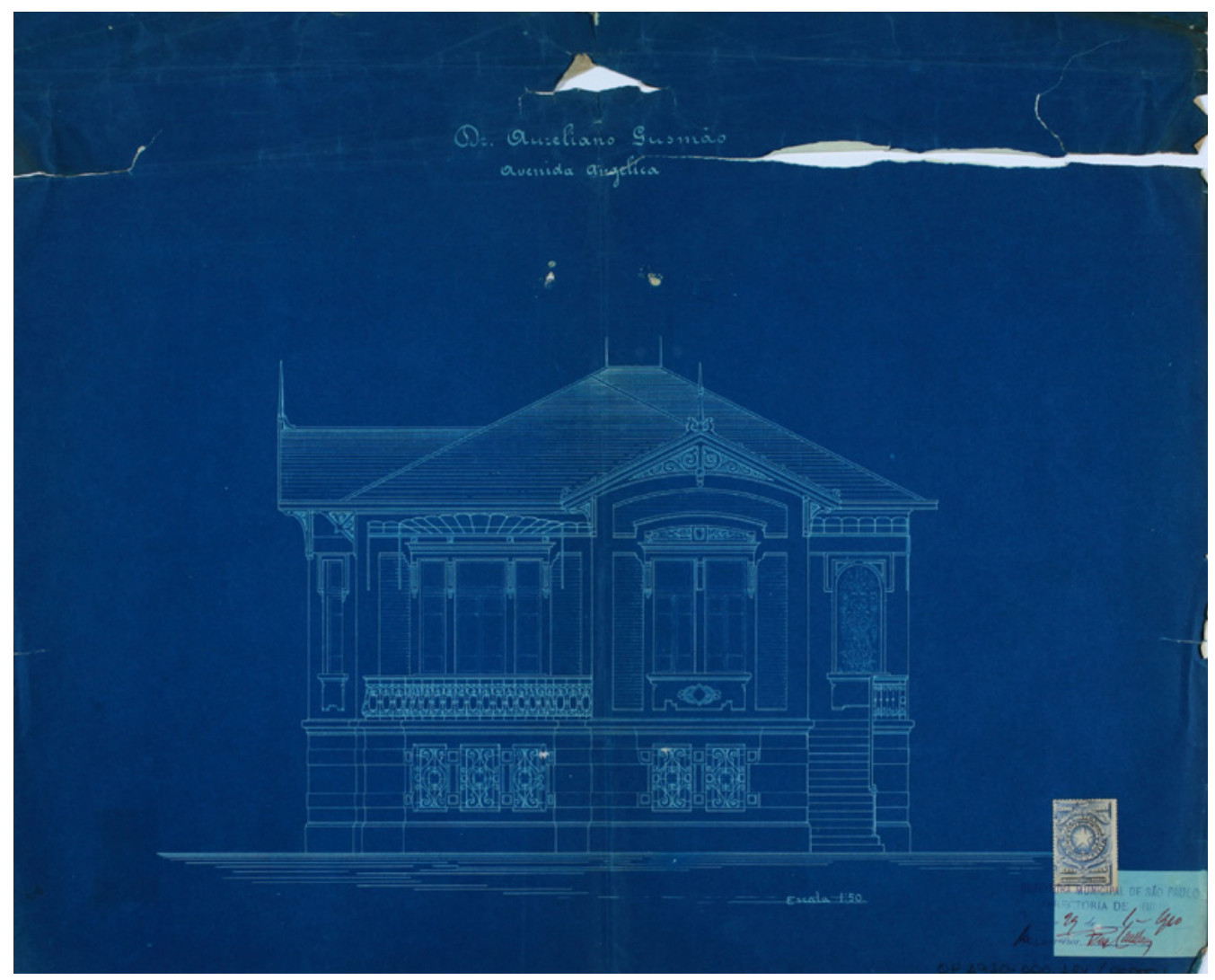

FIG. 56 - Fachada da residência de Aureliano Gusmão, construída pelo Escritório Técnico de Ramos de Azevedo em 1910. Fonte: Fundo de Obras Privadas do AHMSP, OP1910-000124. 


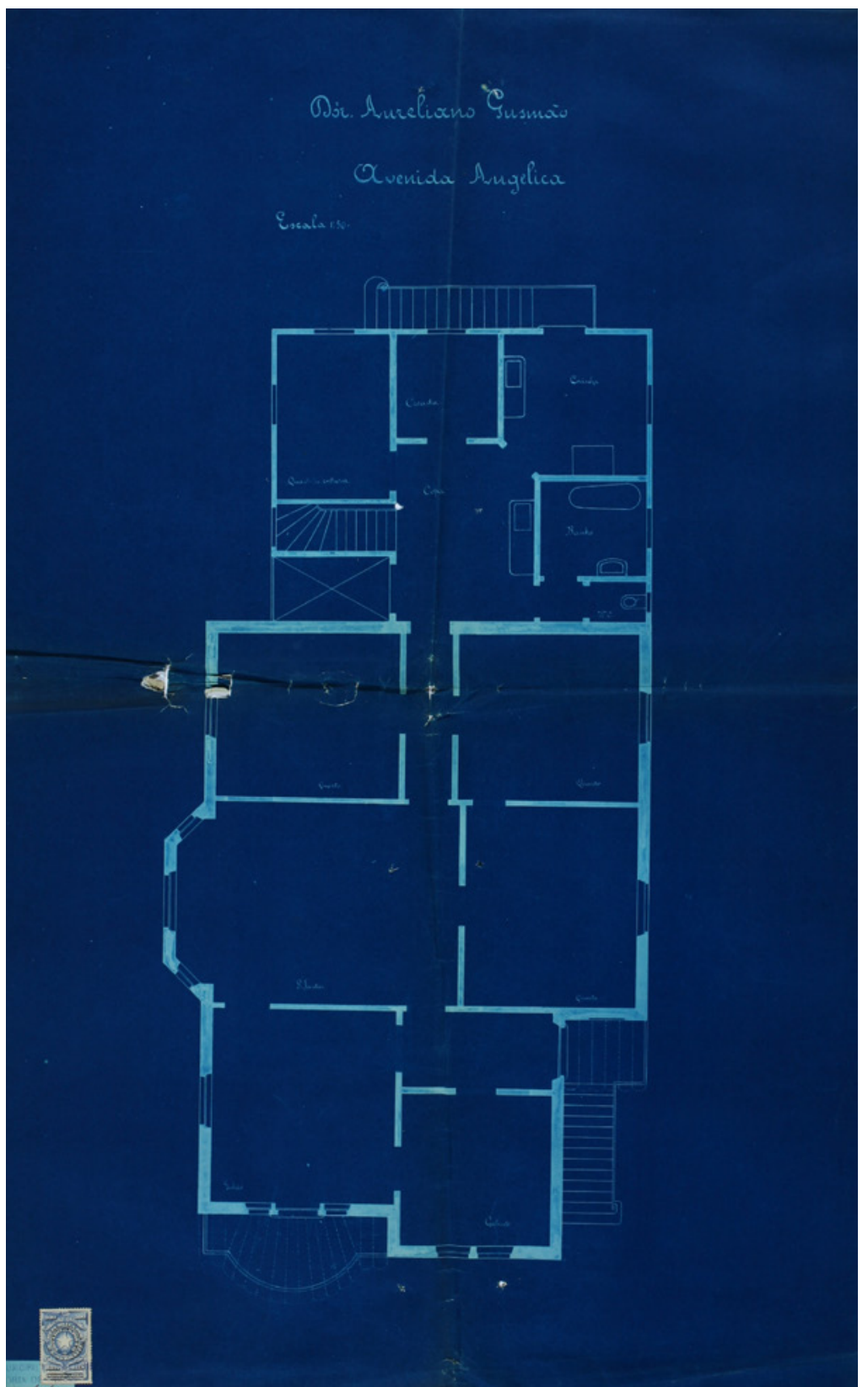

FIG. 57 - Planta da residência de Aureliano Gusmão, construída pelo Escritório Técnico de Ramos de Azevedo em 1910. Fonte: Fundo de Obras Privadas do AHMSP, OP1910-000124. 


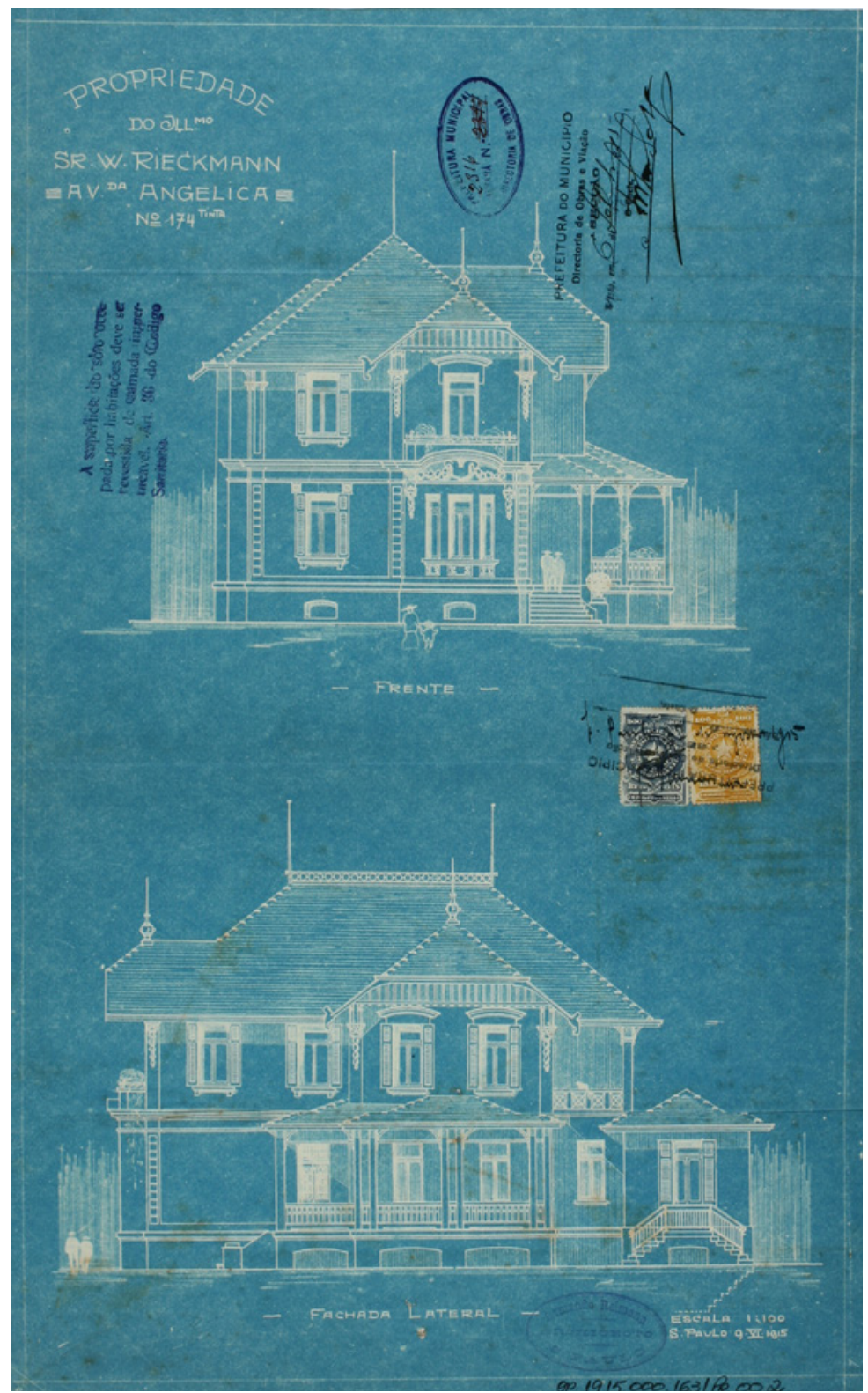

FIG. 58 - Fachada da residência de Werner Rieckamnn, construída em 1915. Fonte: Fundo de Obras Privadas do AHMSP, OP1915-000163. 


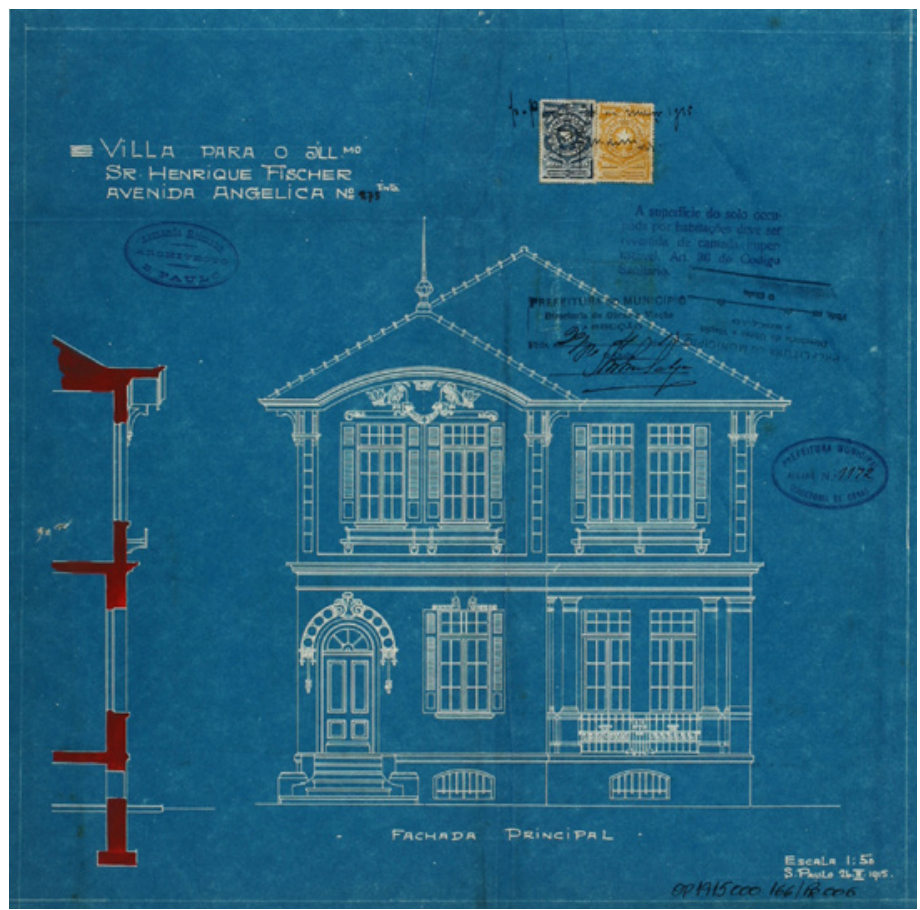

FIG. 59 - Fachada da residência de Henrique Fischer, construída em 1915. Fonte: Fundo de Obras Privadas do AHMSP, OP1915_000166.

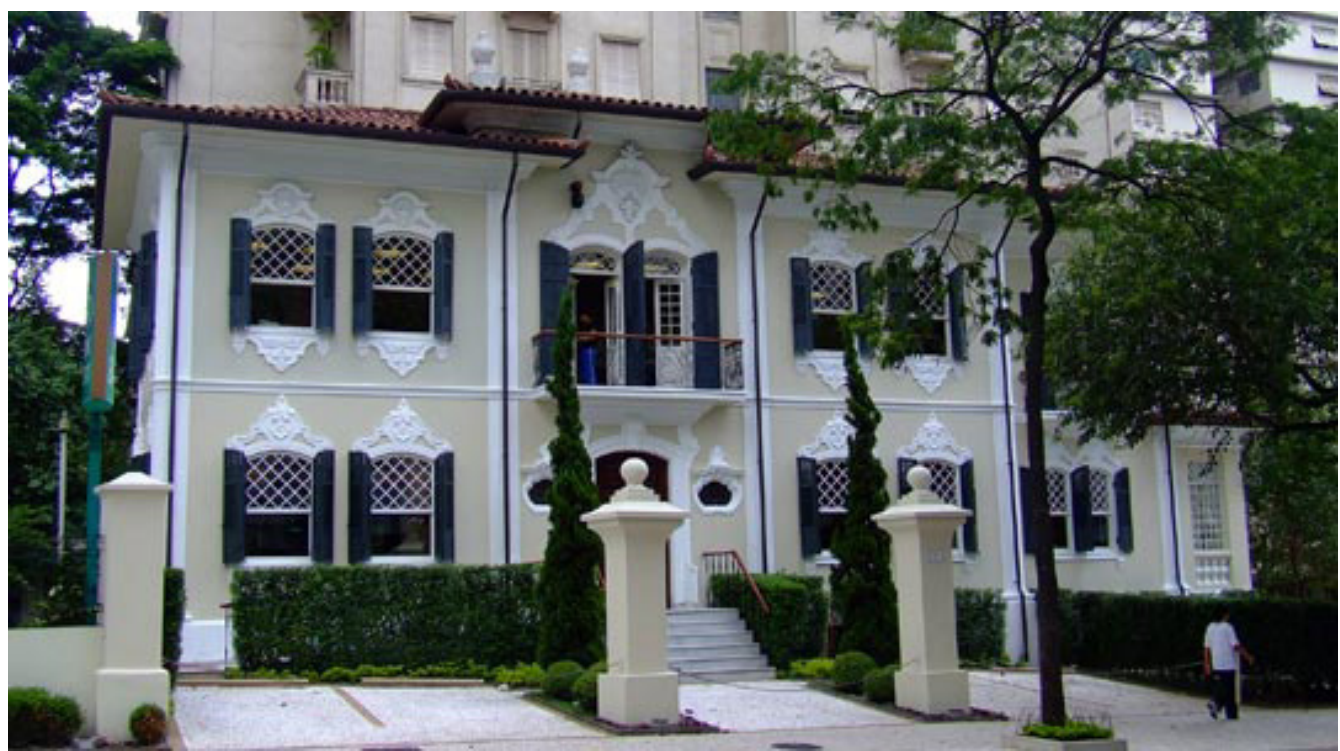

FIG. 60 - Foto da residência de Adolfo Schmidt Sarmento, construída na esquina da Avenida Angélica com a Higienópolis na década de 1920, em estilo neocolonial. Fonte: https://taishaupt. wordpress.com/ (último acesso em fevereiro de 2017). 


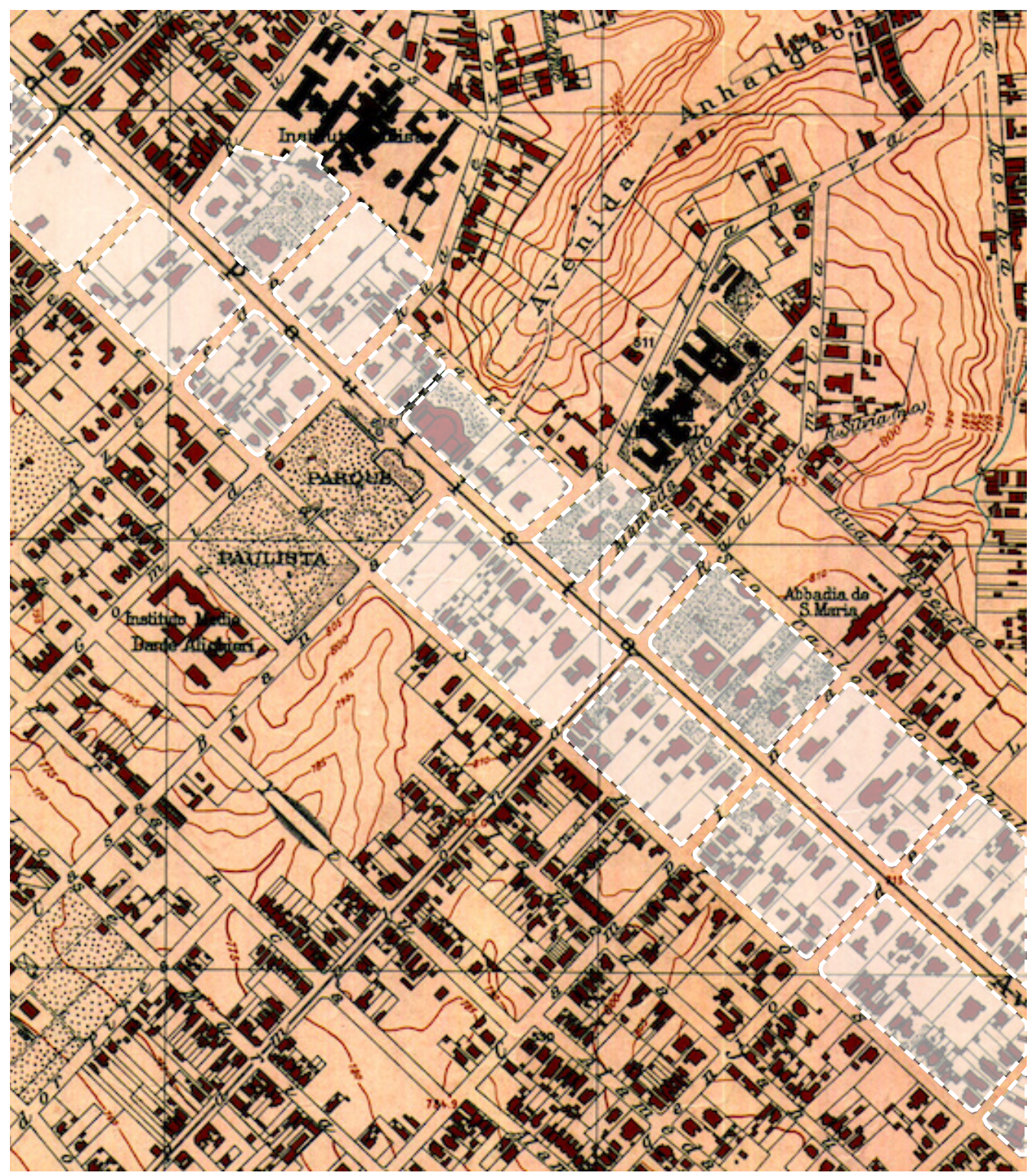

$\mathrm{N}$

FIG. 61 - O ritmo vagaroso e pausado das edificações na Avenida Paulista. Fonte: SARA-Brasil, 1930. 


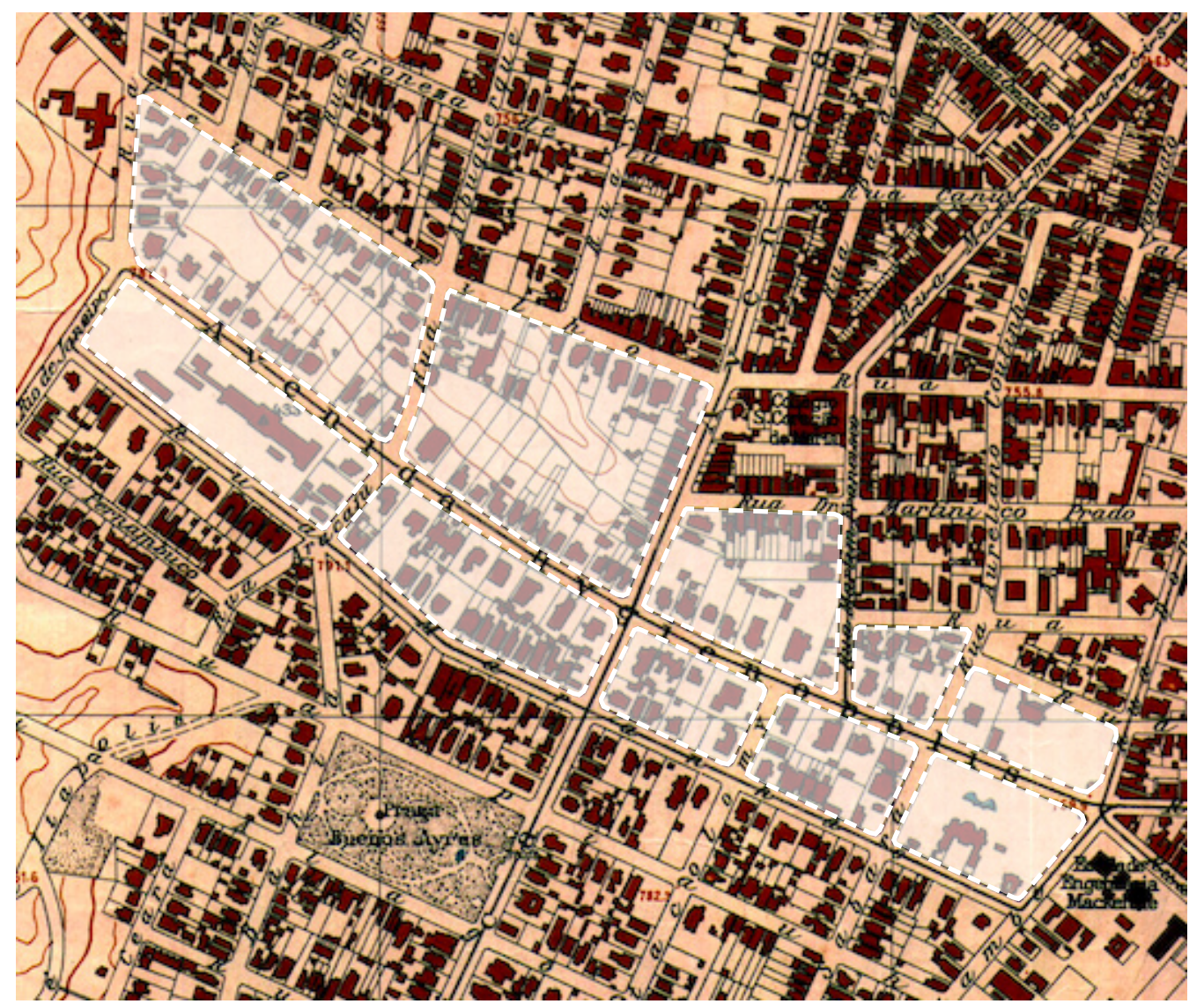

FIG. 62 - Mesmo que um pouco mais intenso, um ritmo também regular e harmônico entre as edificações da Avenida Higienópolis. Fonte: SARA-Brasil, 1930. 


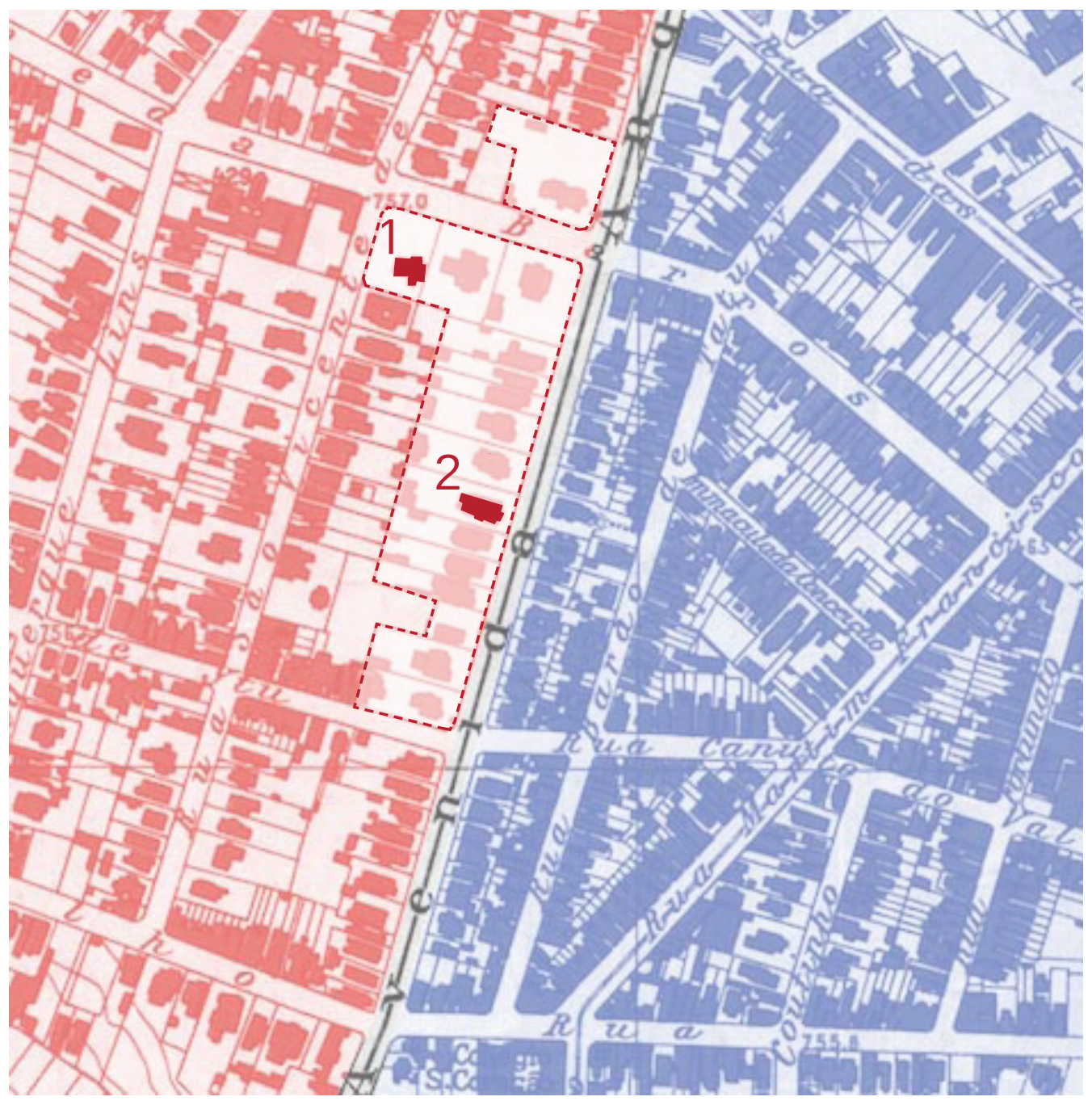

FIG. 63 - O encontro de dois mundos. Em vermelho, a ocupação elitizada e rarefeita das terras de Maria Angélica de Sousa Queiroz Aguiar de Barros. Em azul, a ocupação intensa das casas medianas e operárias das terras de Domingos José Nogueira Jaguaribe. Em destaque pontilhado, a região onde provavelmente estava instalada a parentela de Maria Angélica, nas proximidades de sua residência (1) e de sua prima Sebastiana de Sousa Queiroz (2). Fonte: SARA-Brasil, 1930. 


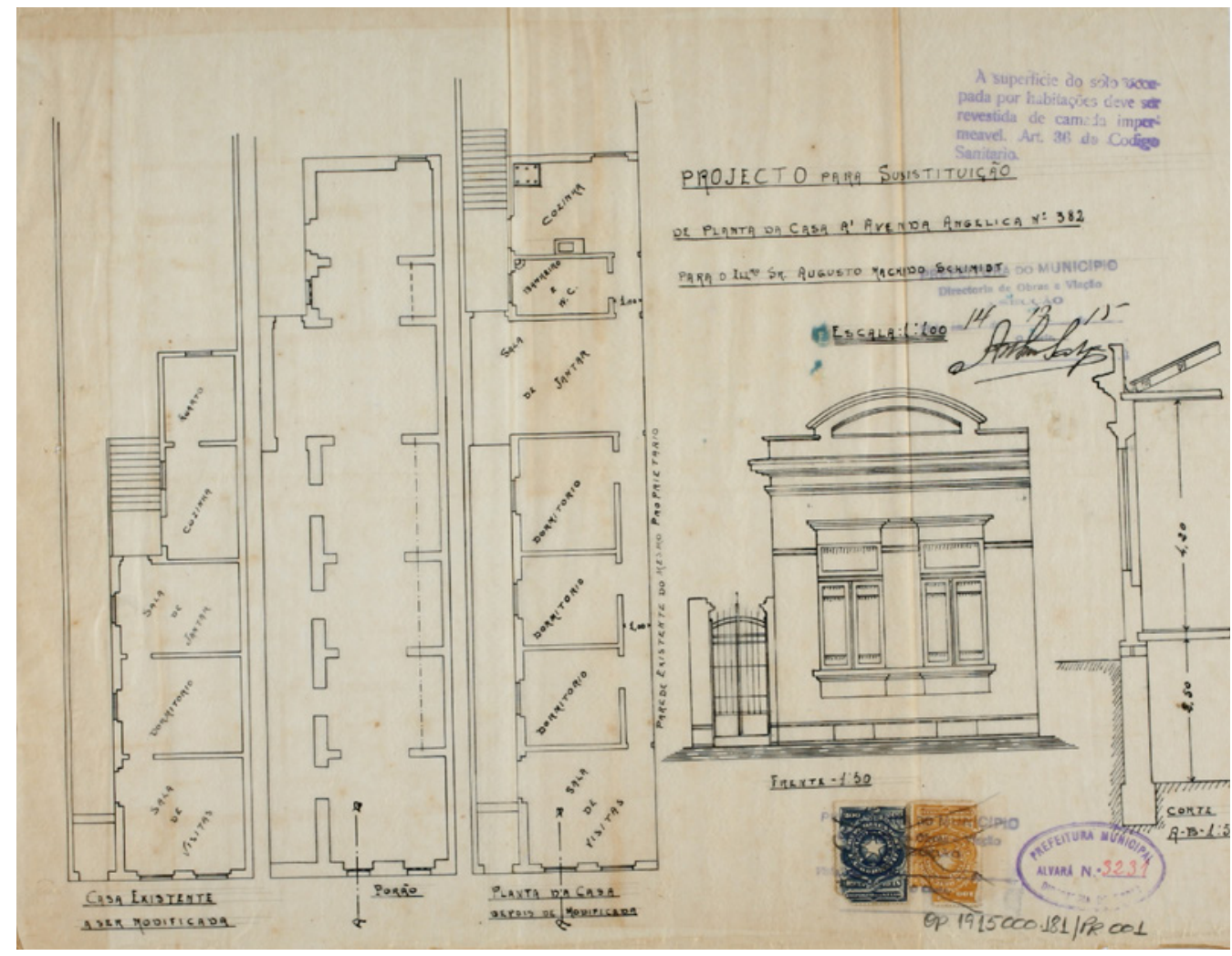

FIG. 64 - Residência reformada por Augusto Machado Schmidt em 1915, na Avenida Angélica, 382. A planta desenhada à esquerda, sinalizando a edificação antes existente no terreno, corresponde à casa onde habitava Augusto Piedade. Nas duas plantas à direita e na elevação, vemos a reforma empreendida por Schmidt, que transforma a casa módica de Piedade em uma residência mediana. Fonte: Fundo de Obras Privadas do AHMSP, OP1915-000181. 


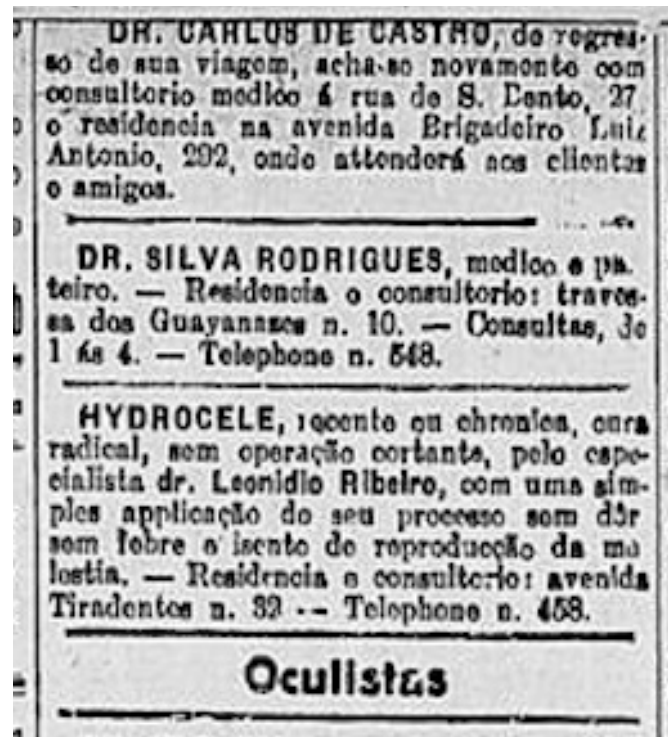

DR. EUMUNUO DE ค.1RVALHO, ceps. cinlista da Vionna o Roma. - Consultoriv: run Diretta n, $06-4$, do 1 \&s 4 .

\section{Engenheiros}

Facriptorio toolnico do engenhoiro SA. MUEL D/S NEVES - Roparasües o cot: trueçöes do predias, orçamentos o projoctos - Ran Qninzo de Norembro, 37 - Telo phoac, 018 - S. Paulo - Avenidn Con. tral, 101 (Nores, Almoida o Comp.)-Rio.

\section{Denfistas}

DR. JOROUIR PINHEIBO PARANA. FAI

GUA DA, JOVINO DE FARIA:-Adro gados. - Transfjrizam o scu eecriptorio para a rua d. Stio Bonto n. 38 .

SPENCER VAMPRE'. - Adrogado intorproto publico ́uramentado do japonez franooz, ingloz, allemto, italiano o hespr. nhol. - Rua Bants Terces n. B. - Resi doncin: rua Dr, Abrapches n. 23.

O ADVOGADO DR, VIRGIIIO E CARVALHO PINTO t,m O ser ascriptor is G, rua do $\mathrm{B}$. Bosto n 45.

DRS. JORGE ARAUJO DA VEIGA E N. MARQUES SCHMIDT, ndrogodoe. Rua Direita, 12.B, das 12 is 4.

DR. GABRIEL DE VIEZENDE, - AJ. vogado, rus Diroitn n. 15 (Banco 2o Tro dito Roal). do 1 is 1 horos da tíme.

CORONEL. AUGUSTO PIEDADE - Pa. trceinio de causas civois, commorciacs, eriminaes o onalanglogicas, on primeira e engundla instancias; deféas - o accugaçüss peranto o jury, ena qualęuer comarea do Pstado; procuratorinas nas repartiçöns pu. blioss; conipra o venda do predias o torre. orir nos; emprestimas hypothecarios: cobran- per cas, ote.-Hothorarios modicos, - Attendo a fox clamades a qualquer bora para serkico ia guil golicia, - Escriptorio: Av. Angelica, $390 ;$ ifa Residencia: Av. Angolica, 332. - S. Pauli. Cor

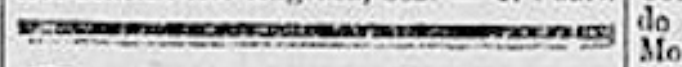
- $\quad$ ber

FIG. 65 - Um dos primeiros anúncios do Coronel Augusto Piedade, pouco depois de chegar a São Paulo. Fonte: Correio Paulistano, 1910. 
DR. CIARIES SPEERS, - M. R. C. S., L. R. C. P. London). Medico e operador. Res.: Alameds Bduardo Prado, 12. Telephone, 2.379. Consultorio: rua de S. Bento, 63, sobrado, das 2 ta $\$$ da tarde. Telophone, 1.023.

DR. L. F. MARDIM - Eop. em mo. leatias do monhoras; cons. : rua Anbaniza. bahu', 103 (sob). Das 2 As $5 \mathrm{~h}$, da tarde. Tel. 1.462 Res, tua Helvetia, 26; telop: 1.513.

DR. A. MEDEIROS - Molestias das creanças o syphilis, - Res. Rus Libordade, 9. - Cons.: de 8 as 9 o mela. Telph.: 88. - Consultorio: rus Thesou. ro, 3, de 1 is 4 .

Vins urinarias, Polle, Syphilis (applic. indolor do CDG). Molestias tins Sonhoras, Tumores do ventre, Partos o 0 poraços, Especialidades estudadins na Allemenha o pratica $\mathrm{ng}$ Maternidade 0 hotpitaes do hito, pelo dr. Jolio de Ollveira, geo reside na rua Tabatinguera, 16 - Consuliorio: Rua Boa Visia n. I (2 is 5).

DR. JONO RANGEL, - Med:io dea. tisto. - Consultorio: rus S. Bento, 62. Residencia: alameda Nothmann, ss. Telephone, 418.

DR. AMLARANTE CRUZ. - Operador - parteiro. - Consultorio: rua do The. souro n. 9, das 12 ds 2 hores do tarde. Telephono n. 709. - Rosidencia; rua Seto do Abrilsn. 68. - S. Paulo
MKO IIEL LIAIEISTER - ESDILAS PACIIECO FERREIRA, advogados.- Advogam gratuitamente para co rccunhecidamento pobres. - Residencia: rua das Palmeiras, 19; alameda Barîo do Rio Branco, 3. - Escriplorio: rus de S. Bento, 47. - S. Pavlo.

DN. PEDRO DO MONTE ABLAS, advostado, - Bacriptorio: rus Santa Toresa, 12. Residencis: largo da Liberds. de, 5 .

DRS. JOAO MANTIN E SILVA. - Advogado. - Travessa da Só, 12.

Adyogados - DRS. SALLES BRAGA - F. SOLANo. - Rua S. Leopsklo, 18 (sóbrado). - Santos.

CORONEr AUGUSTO PIEDADE DR. ANTONIO AUGUSTO RODRIGUES DE MONAES (juiz d, direito aposents do). - Actos lorenses e judiciarios. Emprestimos - Compra e venila de immoveis. - Procuratoria nas repartiçoes publicas, oto, eto. - Eacriptorio: avenida Angetica, 820, provisot nonte. - Das 11 as 3 horas da tarde.

Os DIS. ADOLPHO A. DA SILVA GORDO - ANTONIO MERCADO, lom - sou escriptorio \& rua do S. Bento n. 45, eobrado - Tolephone a, 440:

DR. FAUST0 FERRAZ. - Advogado. - Bacriptorio: rua Quiazo de Novem. bN n. BO-B. - Résidencis: Aveñids Paulista 1483 , 5 .

FIG. 66 - Anúncio do Coronel Augusto Piedade e do Dr. Antônio Augusto Rodrigues de Moraes, no qual se nota a inversão simbólica de seu endereço ao longo de sua trajetória: se anos antes era motivo de orgulho, agora o escritório na Angélica é motivo de acanhamento, figurando por mais de um ano como endereço provisório nos anúncios da dupla. Fonte: Correio Paulistano, 1912. 


\section{Gabinete dentario}

No dis 1 a decto max, an 3 horas da tarde, es ecahofitas dras. Francises o Au. gusta Pindade, cirunging dontistas, forma. dis om dewembro altimo. fiscram bonwer - gabinete doatario que inutallaram cm Gu residencia, a avrition Angeliex n. 161 , pela tigario do Bells Vixs, exma. \&. $\infty$ nago Adotiro Kratues wrindo de pedrtato exmo. of. dr. Alsaca M. Guima rist, reprosentado por ana blka Abraro Guimarît Junior, e ous esposs, exta. 8ta. d. Maria Piado Grimaríce. As acto concorteram muitas onboritas. senhoras o carialleciros. is quaces o ar. Han. rique sampsio, electricista que no incumbira do respectiro servico do rentagem, fex minuctosn o agradsvel axposicito do todo o'manchiniseo inatallado. foracosodo tsmbem exempics pratiocos do fubccionsmento especial de cadn poca, astivarendo amplamento a todas os axisteates is agradarelisento Imprestionados com o bom gato artistico e exthotion das installaLes o dos materises do que se echn cons. tituido o gabinete, nảo osmento os destinados l cinurgia, como os especiacs para noits, into; anbs, protheos, todos serridos pela electricidado - do eparado groto.

Im begaida, apts alguma mosica to piano. foi serrids lauta ness do licores - doces, demoraadoos os assistentes em ras da amistors palestra ale depois de 5 botas. As acohoritas Piedado contiauan reoebxado auitas felieitaç̄es.

FIG. 67 - Notícia da inauguração do gabinete dentário das irmãs Piedade. Fonte: Correio Paulistano, 1913. 


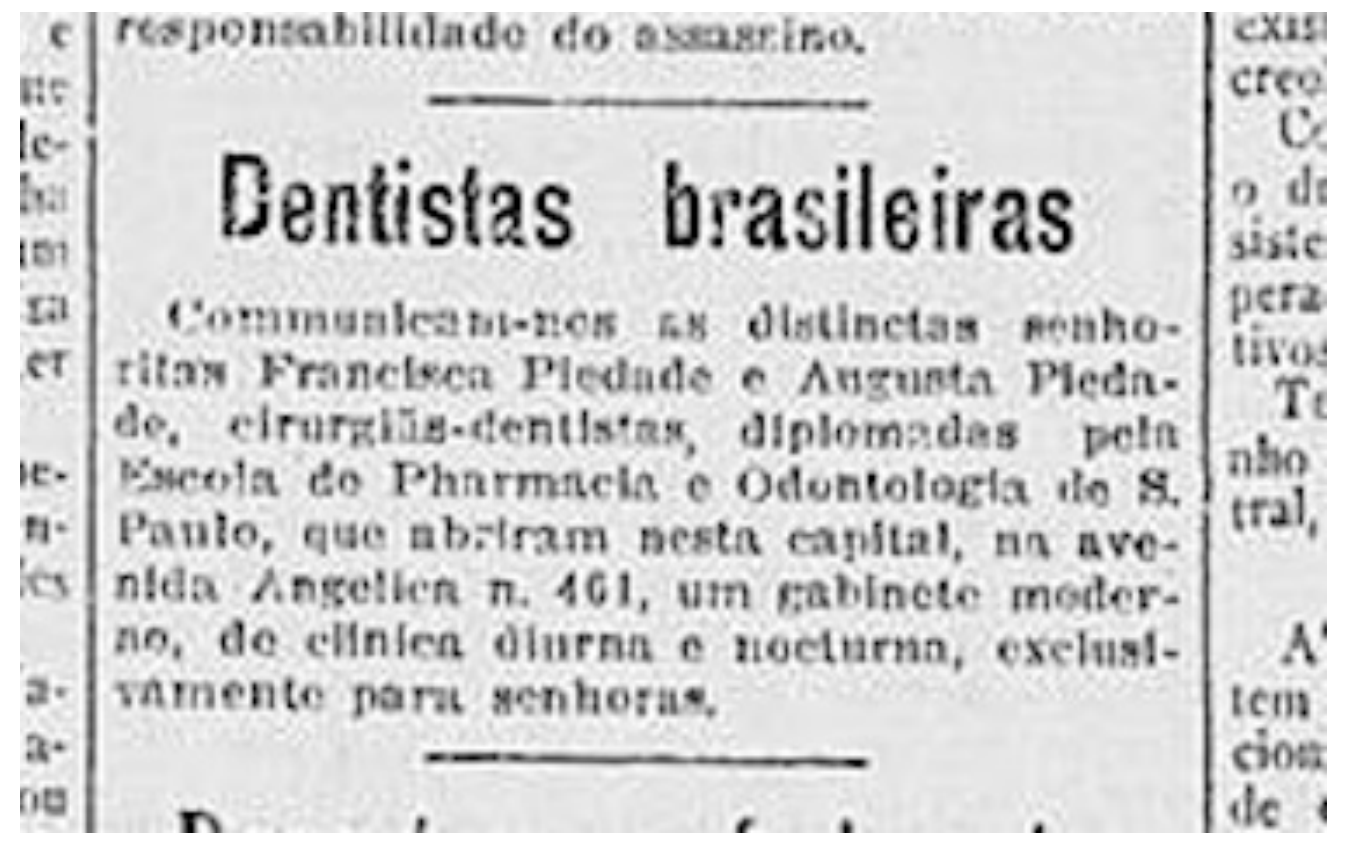

FIG. 68 - Anúncio do gabinete dentário das irmãs Piedade, no qual apresentam o consultório como exclusivo para mulheres. Fonte: Correio Paulistano, 1913. 

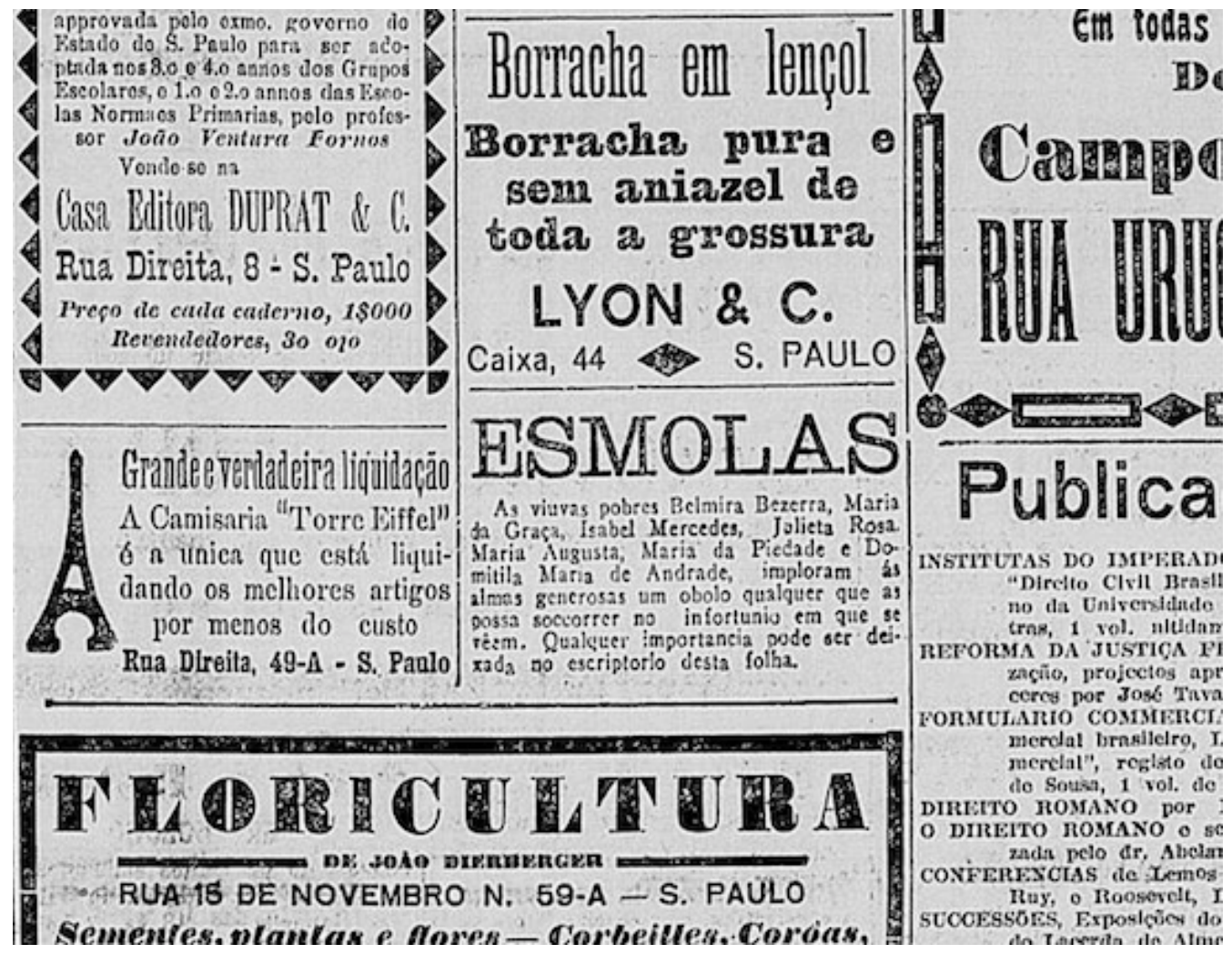

INSTITUTAS DO IMIPERAD "Direto Clvil Brasl! no da Enlversitite tras, 1 vol. altdan REFORMA DA JUSTICA PI zaciito, projectos apr cercy por Jose Tava Formusto cosmerter merdal brasilelro, $\mathbf{I}$ merelal", reglsto do to Sotisa, 1 vol. de

DIREETO ROMANO por

o DIrEITo rosano o sc zada pelo $\mathrm{dr}$, Ahclan CONFERFXCIAS de temos. Ruy, o Roosevelt, I StCCESSOES, Exposiçòn do

FIG. 69 - Anúncio no qual viúvas “pobres” imploram por esmolas. As doações eram deixadas na redação do jornal. Fonte: Correio Paulistano. 


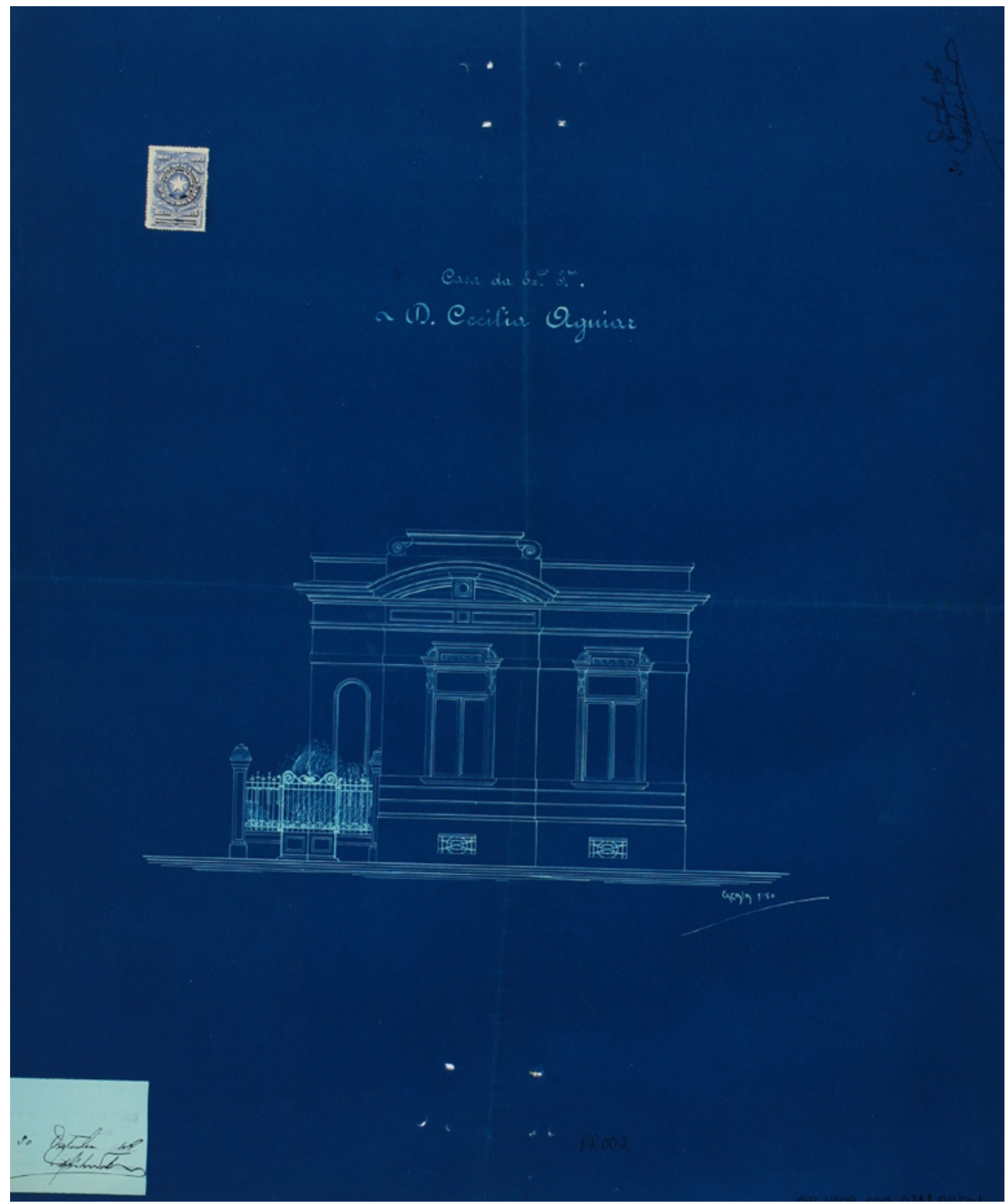

FIG. 70 - Fachada da residência de Cecília Aguiar, construída em 1908 pelo Escritório Técnico de Ramos de Azevedo. Fonte: Fundo de Obras Privadas do AHMSP. 


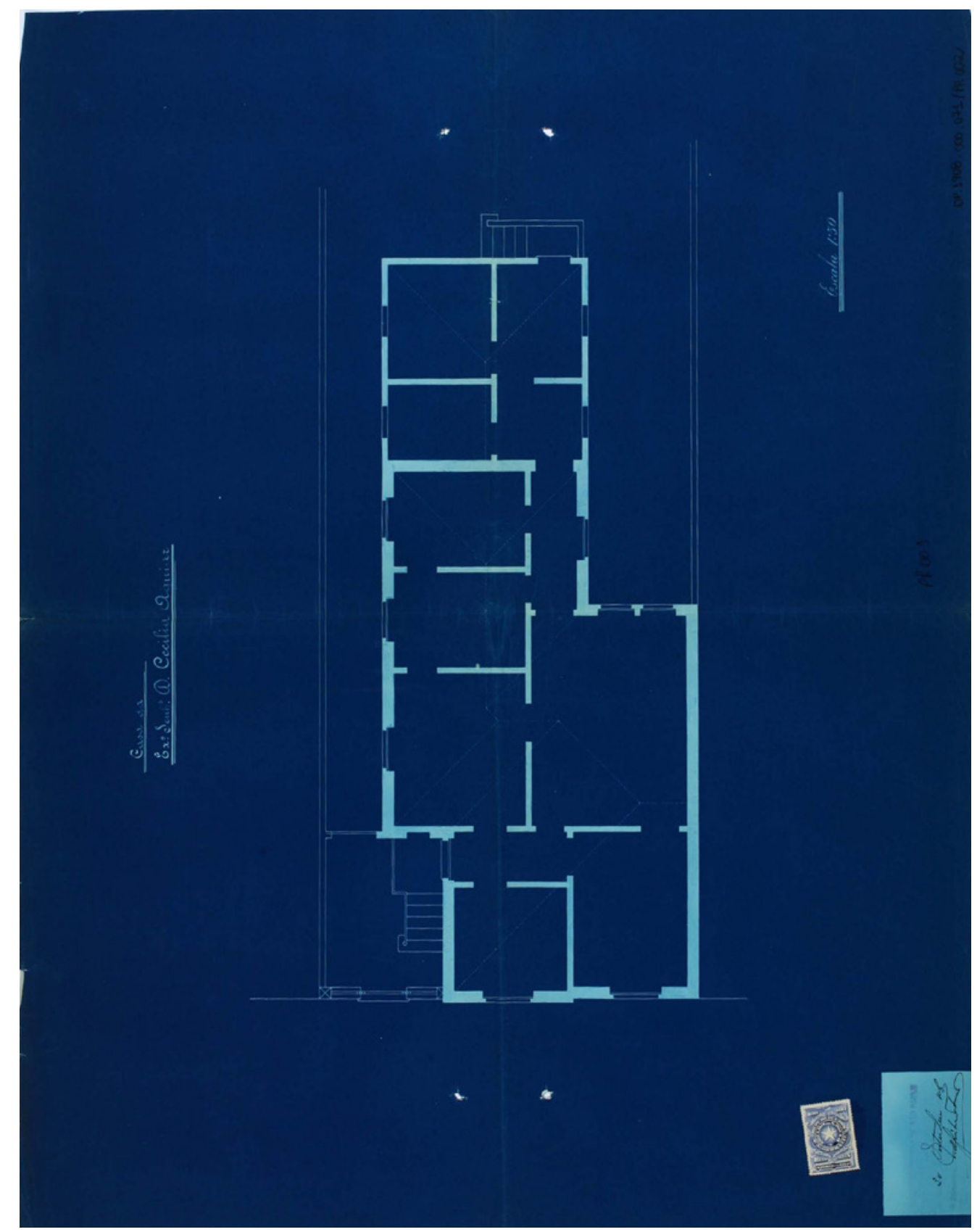

FIG. 71 - Planta da residência de Cecília Aguiar, construída em 1908 pelo Escritório Técnico de Ramos de Azevedo. Fonte: Fundo de Obras Privadas do AHMSP. 


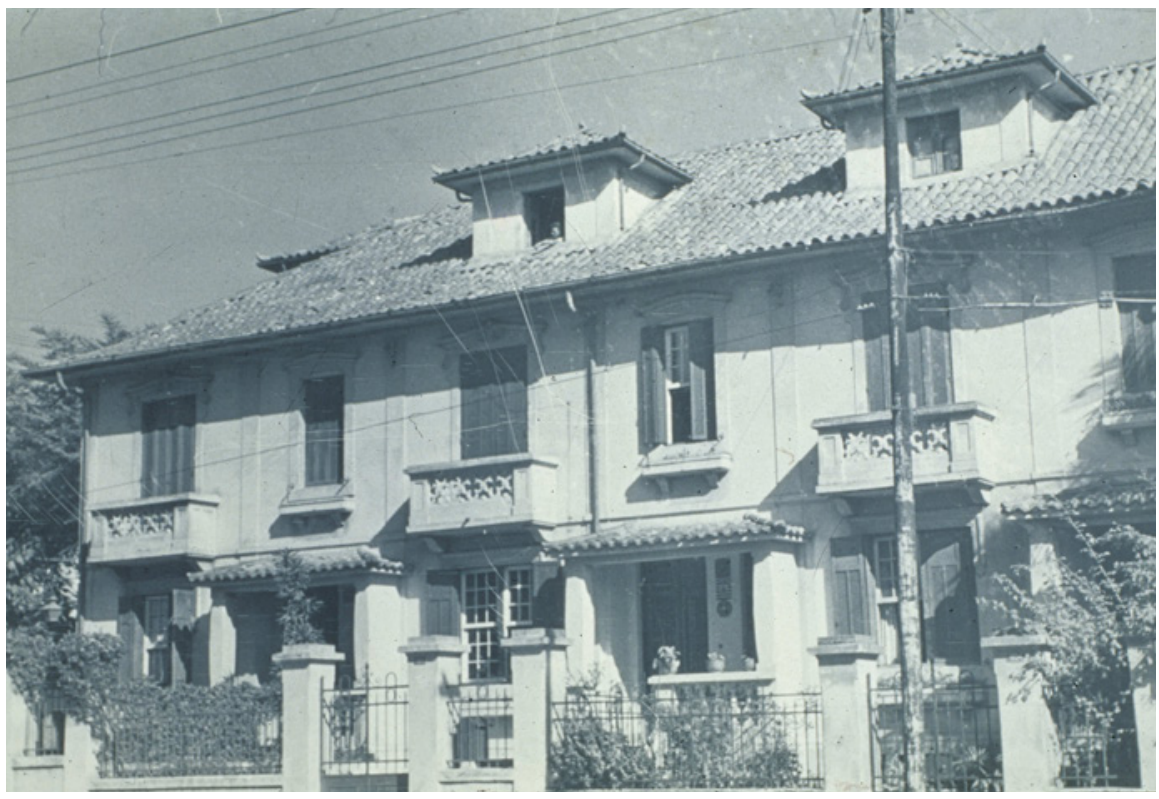

FIG. 72 - Quatro sobrados estreitos e geminados que aparentam ser duas residências de médio porte. Foto de Gustavo Neves da Rocha, c. 1970. Fonte: Acervo da FAU-USP.

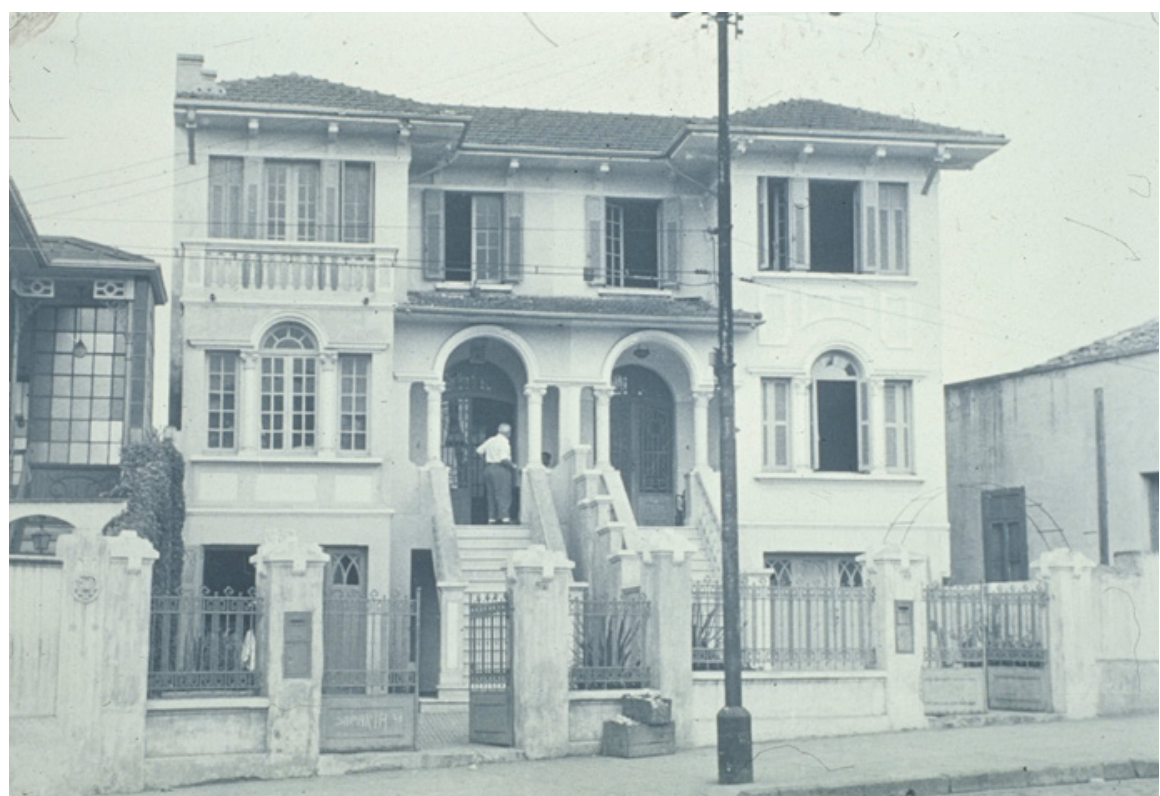

FIG. 73 - Foto de duas residências de classe média localizadas no alto da Avenida Angélica. A composição espelhada, na qual se evidencia a geminação, era a mais comum, provavelmente por ser mais pragmática. Foto de Gustavo Neves da Rocha, c. 1970. Fonte: Acervo da FAU-USP. 


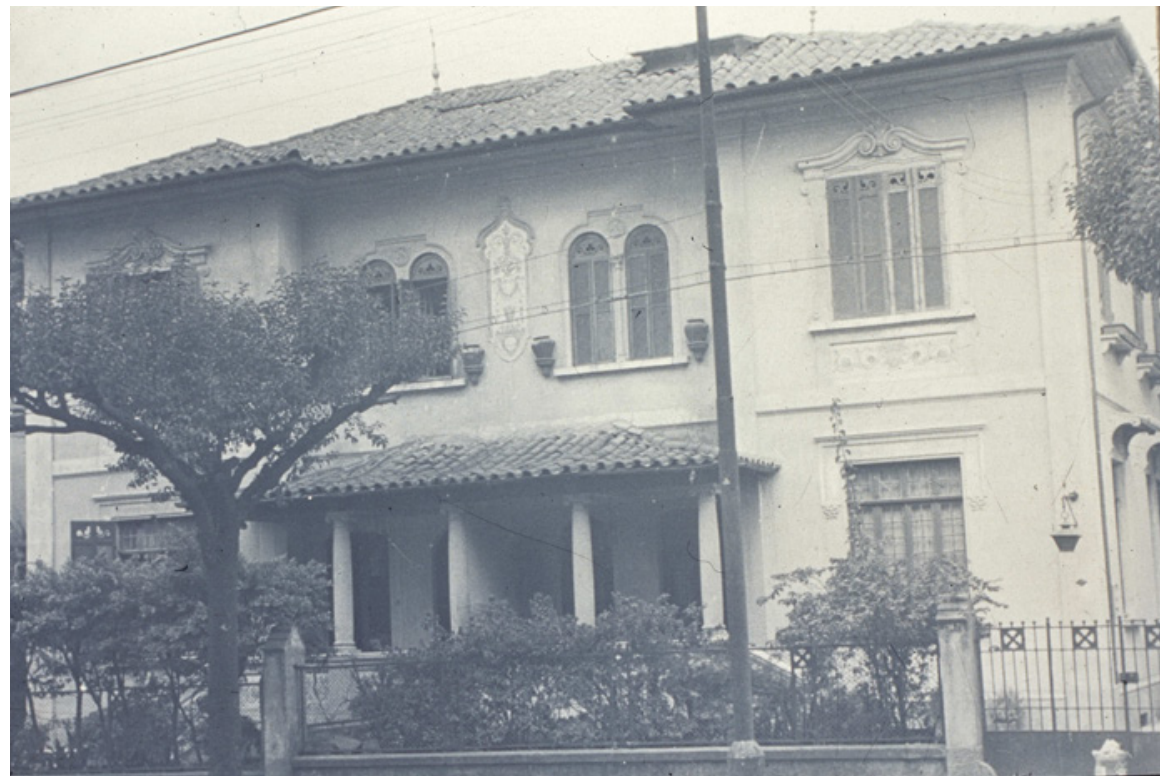

FIG. 74 - Foto das residências geminadas construídas pelo Escritório Ramos de Azevedo em 1910. Foto de Gustavo Neves da Rocha, c. 1970. Fonte: Acervo da FAUUSP.

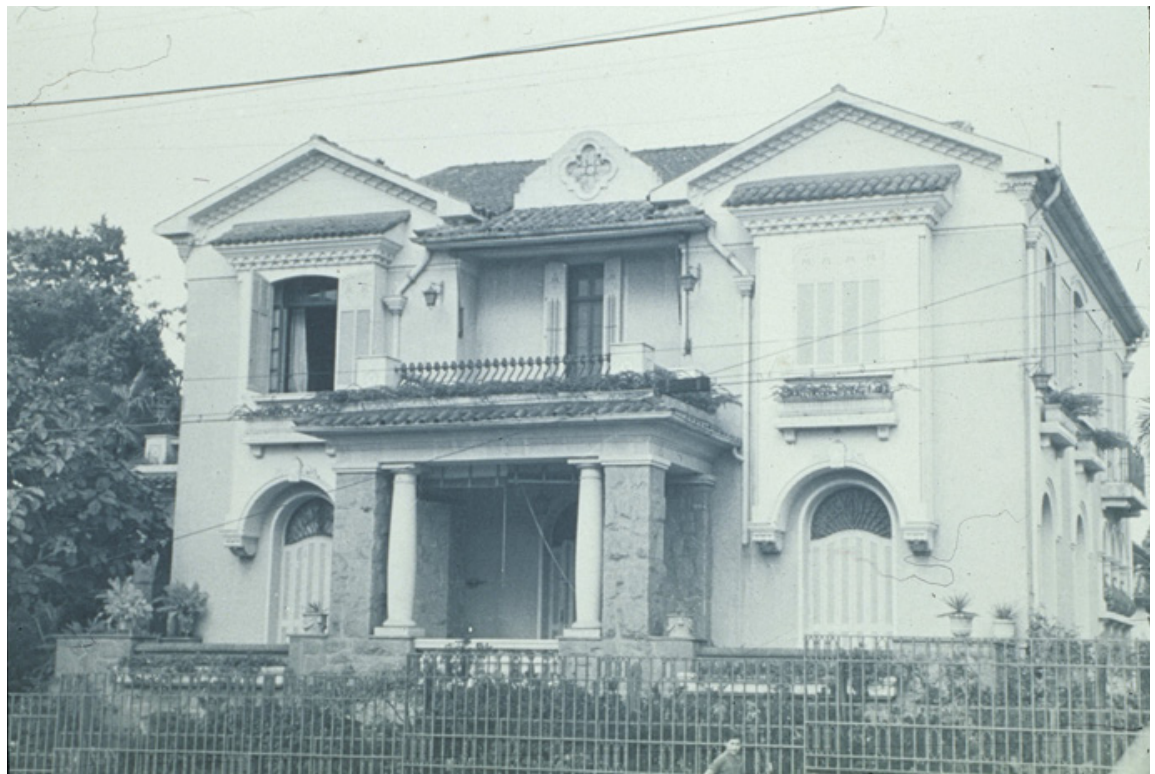

FIG. 75 - Foto de um palacete na Avenida Angélica cuja composição se assemelha muito à emulada pelas duas residências geminadas construídas pelo Escritório Ramos de Azevedo em 1910. Foto de Gustavo Neves da Rocha, c. 1970. Fonte: Acervo da FAU-USP. 


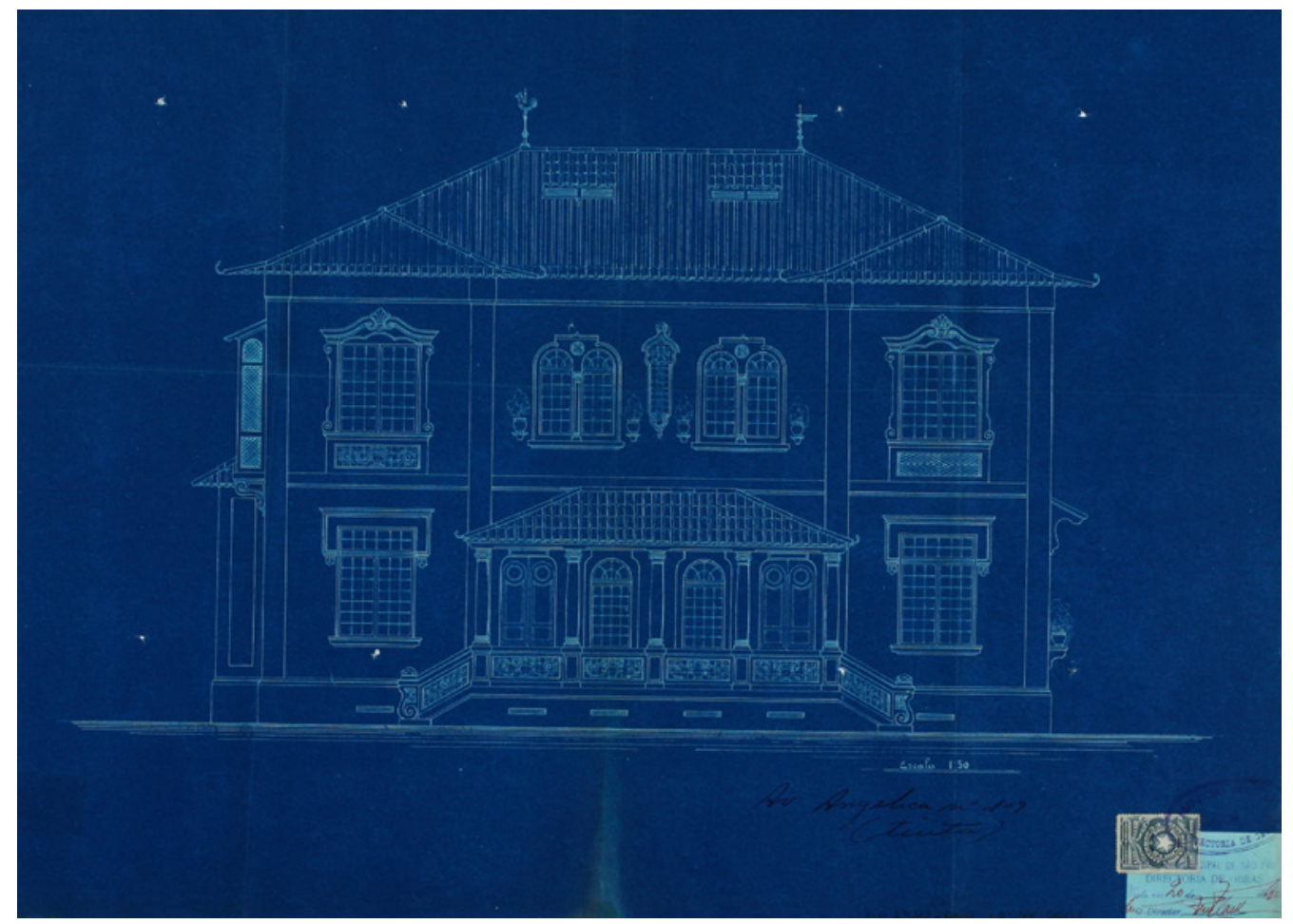

FIG. 76 - Elevação das residências geminadas construídas pelo Escritório Ramos de Azevedo em 1910. Fonte: Fundo de Obras Privadas do AHMSP, OP1910-000121.

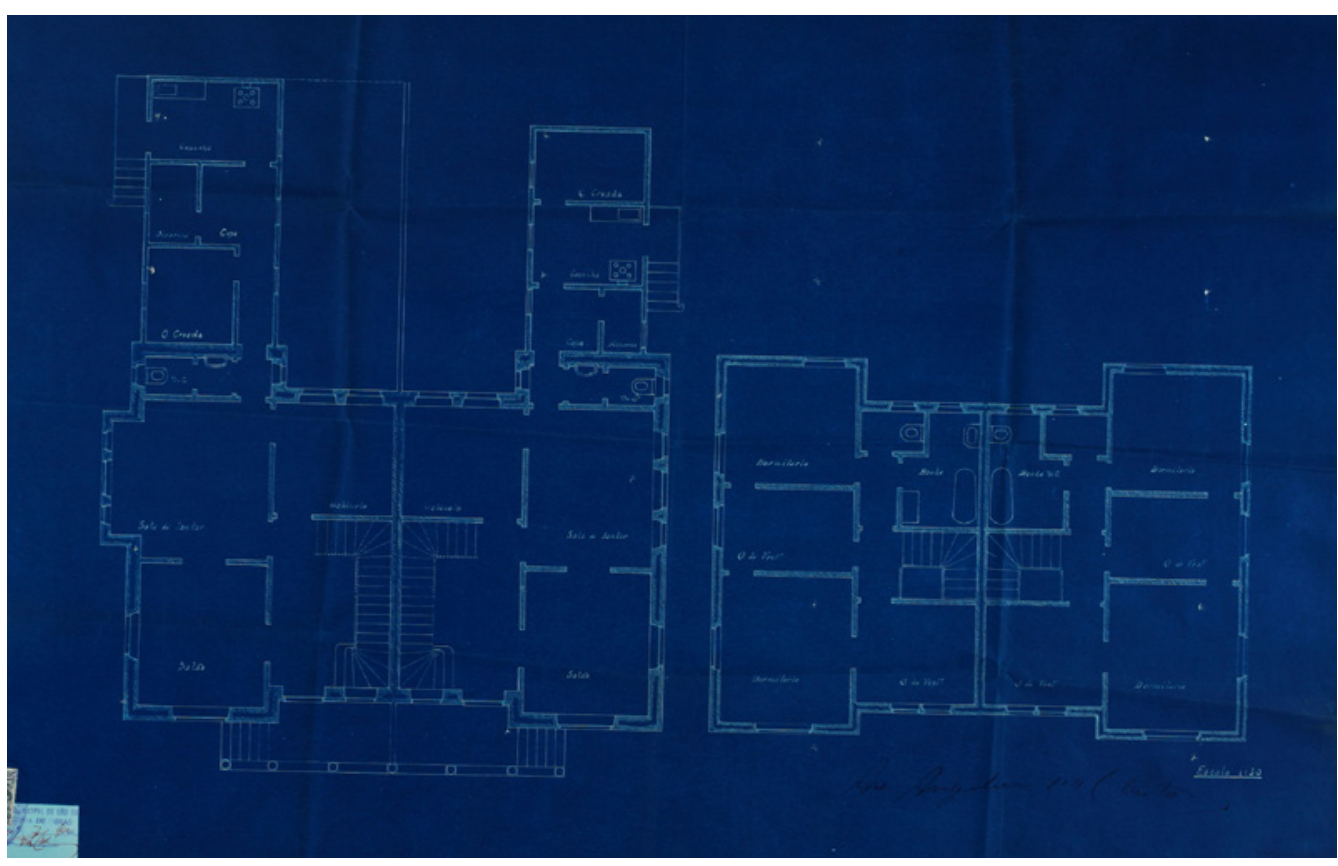

FIG. 77 - Planta das residências geminadas construídas pelo Escritório Ramos de Azevedo em 1910. Fonte: Fundo de Obras Privadas do AHMSP, OP1910-000121. 


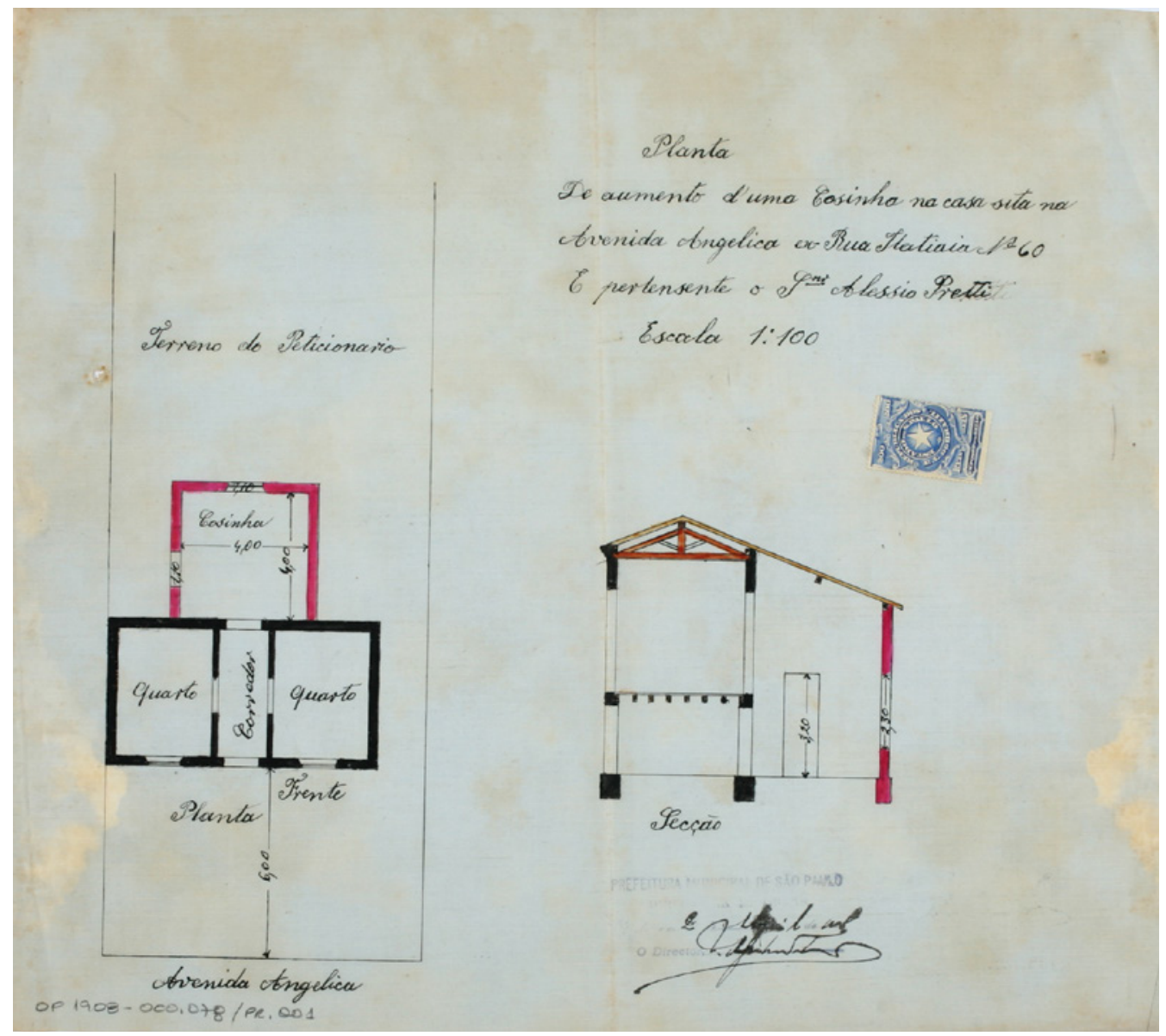

FIG. 78 - Planta da reforma requisitada por Humberto Pretti, em 1913, para ampliação de uma cozinha na casa que pertencia a Alessio Pretti, construída em 1903 (FIG. 19). Fonte: Fundo de Obras Privadas do AHMSP. 


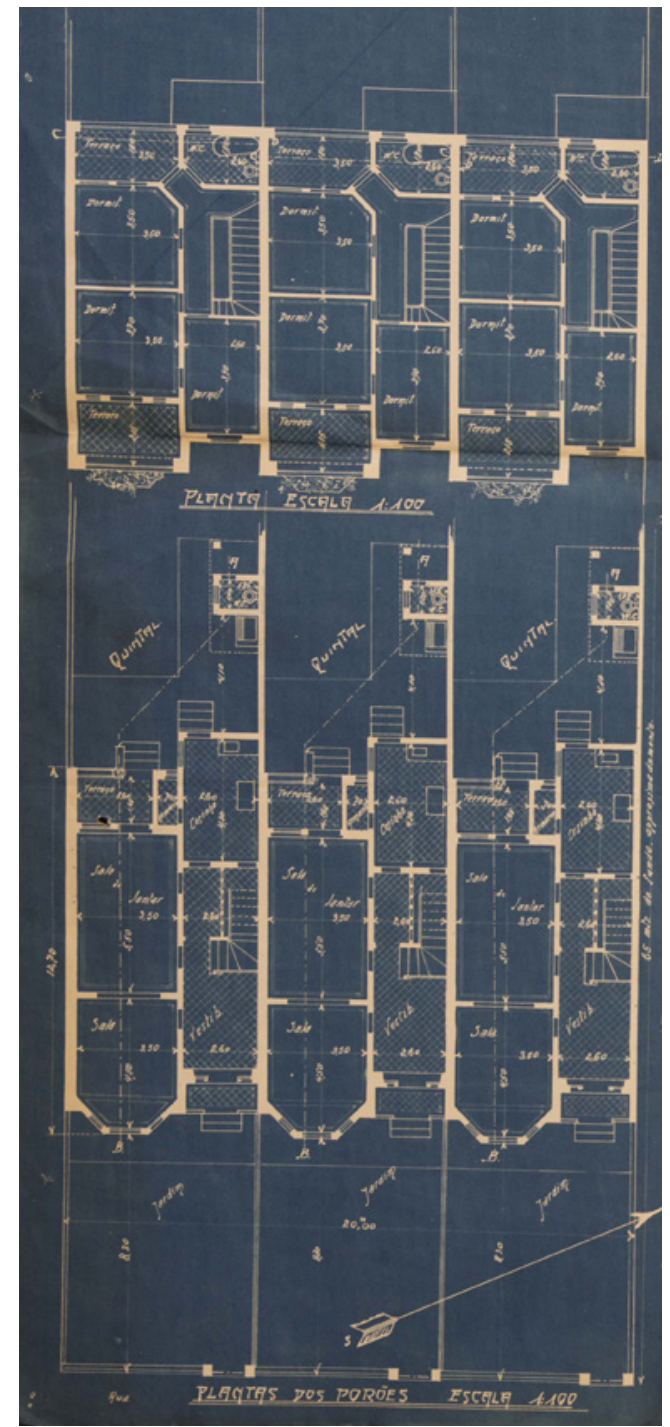

FIG. 79 - Sobrados construídos por Leonor Monteira da Silva em 1913, um deles adquirido por Humberto e Maria Pretti em 1919. Fonte: Fundo de Obras Privadas do AHMSP, OP-1913000.253 .

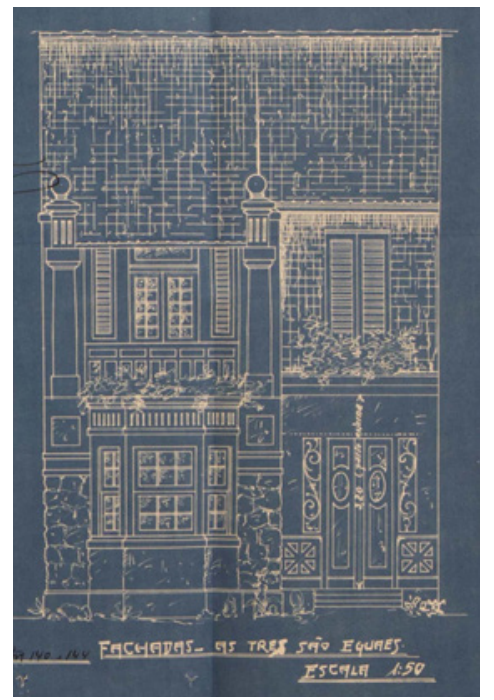

FIG. 80 - Elevação padrão dos sobrados construídos por Leonor Monteira da Silva em 1913. Fonte: Fundo de Obras Privadas do AHMSP, OP-1913-000.253. 


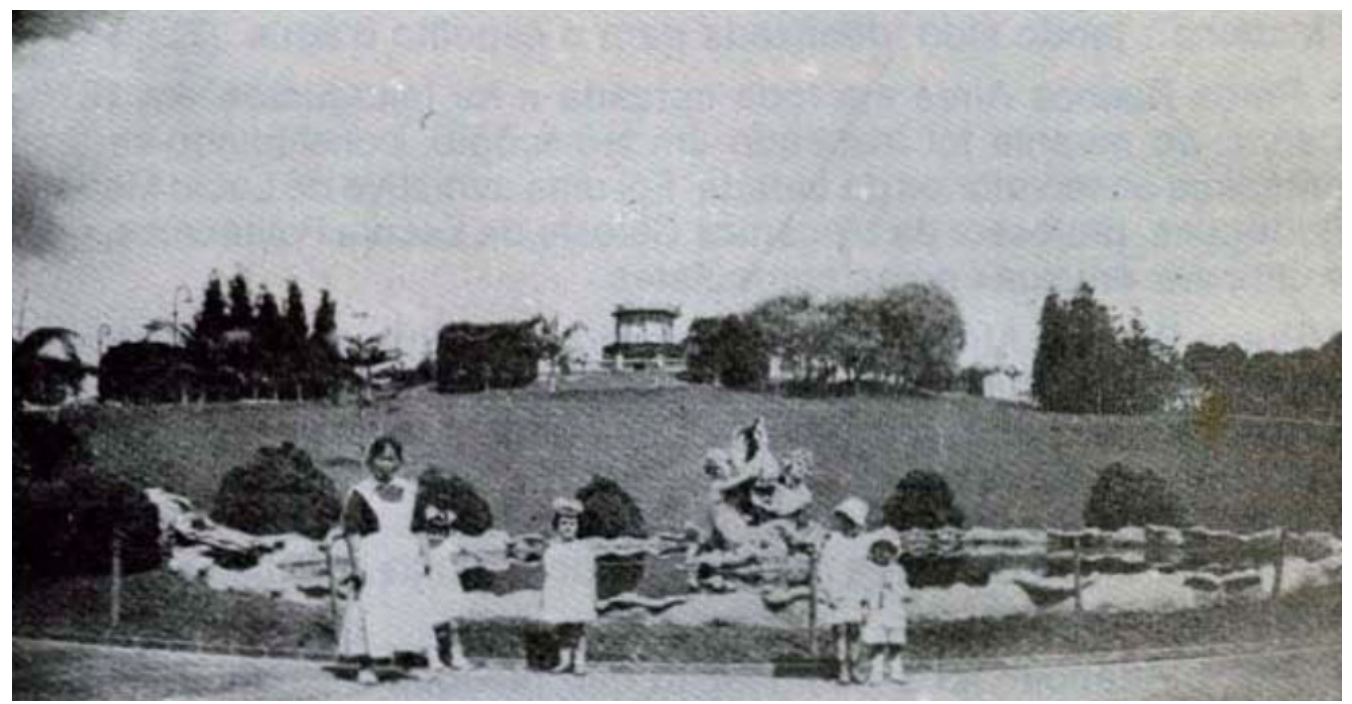

IG. 81 - Foto da Praça Buenos Aires, parte da publicação oficial do município: A capital paulista comemorando o centenário da independência (1922). Figuram como protagonistas desse espaço uma criada e três crianças abastadas. Fonte: HOMEM, 1980.

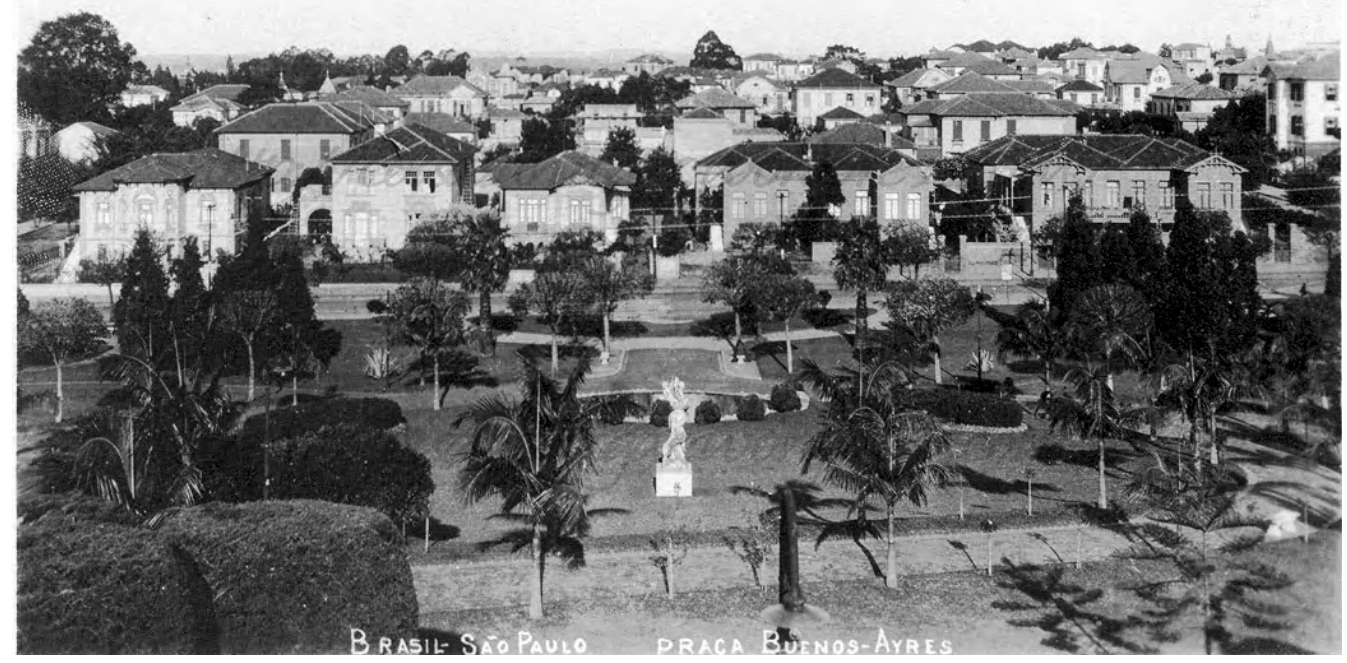

FIG. 82 - Cartão-postal em que a Praça Buenos Aires figura plena e bucólica, s/d. Fonte: https:// sampahistorica.wordpress.com/ (último acesso em fevereiro de 2017). 


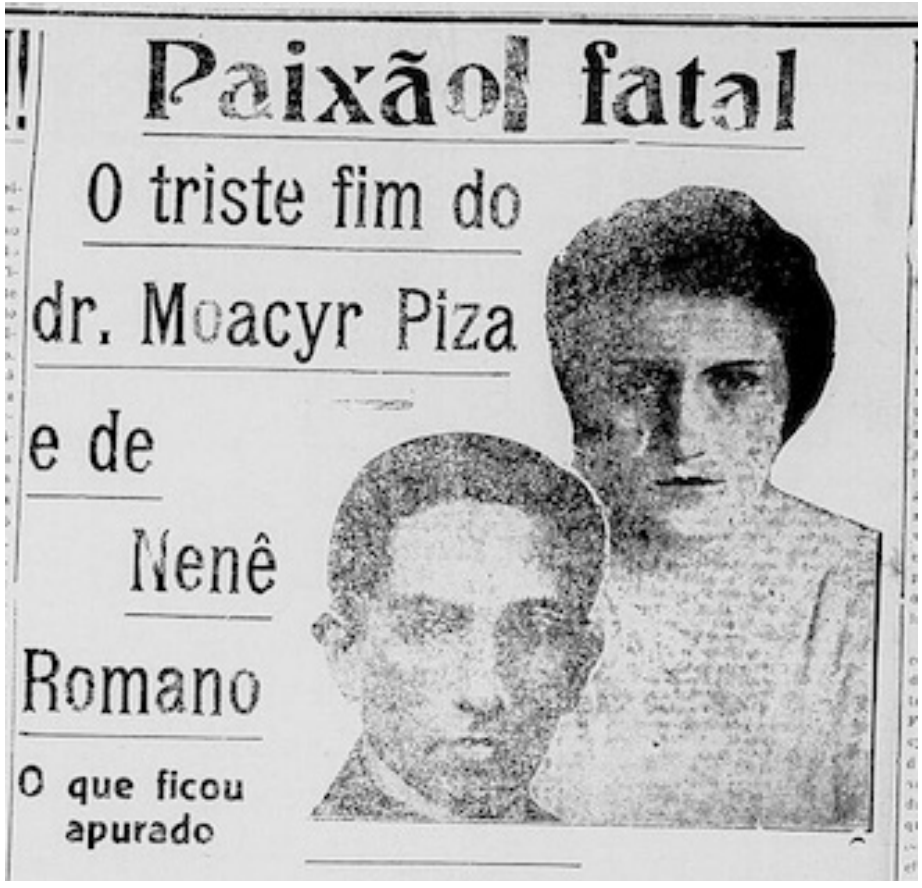

FIG. 83 - Fotografia de Nenê Romano e Moacyr Toledo Piza. Fonte: O Combate, 1923.

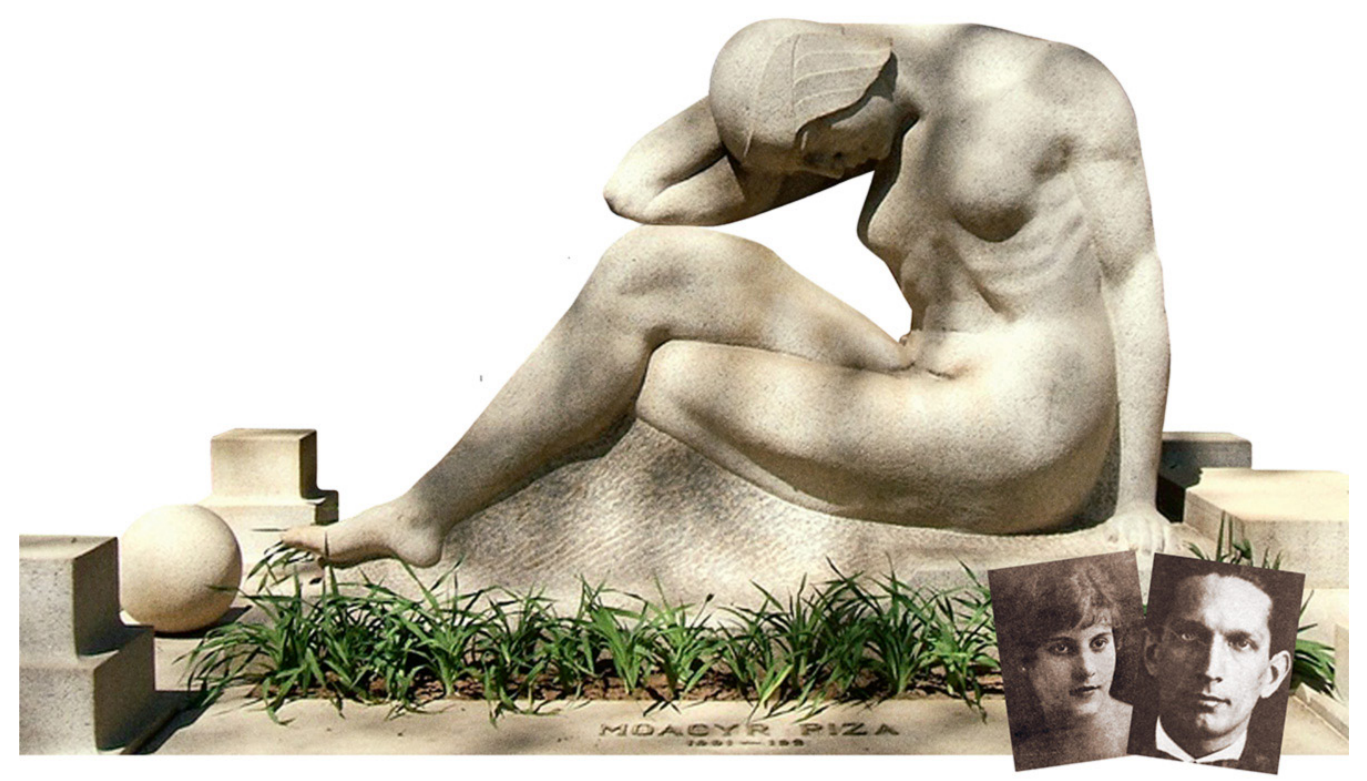

FIG. 84 - Fotografia do Túmulo de Moacyr Toledo Piza. A mulher forma uma interrogação com seu corpo retorcido, expressão da indignação e melancolia da família perante a morte do escritor. Obra realizada pelo escultor Francisco Leopoldo e Silva. Fonte: FAUSTO, 2012. 



\section{Bibliografia}





\section{Obras de Referência}

AB' SABER, Aziz. "Pierre Monbeig: a herança intelectual de um geógrafo". Estudos Avançados, 1994, São Paulo, vol.8, n.22, pp. 221-232

AMARAL, Aracy. O modernismo brasileiro e o contexto cultural dos anos 20. Revista USP, São Paulo, n. 94, p.9-18, jun/ago 2012.

ANDRADE, Oswald de. Um homem sem profissão: sob as ordens de mamãe. Rio de Janeiro: Ed. Globo, 2002

ARIÈS, Phillipe. História social da criança e da família. Rio de Janeiro: Zahar Editores, 1978, p. 195-275.

BACZKO, Bronislaw. Imaginação social. In: Enciclopédia Einaudi. Lisboa: Antropos, 1985.

BALSANOBRE, Sabrina Garcia. A História de São Paulo no ano de 1918 pelo olhar do jornalismo militante: uma análise dos gêneros textuais de O Combate. In.: Anais do VI Siget (Simpósio Internacional de Estudos de Gêneros Textuais), 2012.

BARBUY, Heloísa. A cidade-exposição: Comércio e Cosmopolitismo em São Paulo, 1860-1914. São Paulo: Edusp, 2006.

BARBUY, Heloisa. A Exposição Universal de 1889 em Paris: visão e representação na sociedade industrial. São Paulo: Loyola; História Social USP, 1999.

BARROS, José D’Assunção. A história cultural e a contribuição de Roger Chartier. Diálogos - Revista do Departamento de História e do Programa de PósGraduação em História, vol. 9,núm. 1, 2005, p. 125-141.

BARTH, Frederik. Grupos Étnicos e suas fronteiras. In: POUTIGNAT, Phillip e STREIFF-FERNART, Jocelyne (org.). Teorias da etnicidade. São Paulo: Ed. Unesp, 2011, p. 188-227

BASTIDE, Roger. Os suicídios em São Paulo, segundo a cor. Boletim de Sociologia da Universidade de São Paulo, São Paulo, USP, n.71, p.1-49. 1943. 
BASTOS, Rodrigo Almeida. O urbanismo conveniente luso-brasileiro na formação de povoações em Minas Gerais no século XVIII. Anais do Museu Paulista. 2012, vol.20, n.1

BEGUIN, François. As maquinarias inglesas do conforto. Espaço e Debates no 34, 1991, pp. 39-54.

BERMAN, Marshall.Tudo que é sólido desmancha no ar: a aventura da modernidade. São Paulo: Cia das Letras, 1986

BORIN, Monique Félix. Barra Funda e o fazer da cidade: experiências da urbanização em São Paulo (1890-1920). Dissertação (Mestrado) - FFLCH-USP, 2014.

BORIN, Monique. Acervos históricos e estudos da urbanização: cruzamentos de fontes urbanísticas e judiciárias como recurso metodológico. IV Encontro da Associação Nacional de Pesquisa e Pós-Graduação em Arquitetura e Urbanismo. Anais: Porto Alegre, 2016 (versão digital). Disponível em: http://www.anparq.org.br/dvd-enanparq-4/SESSAO\%2042/S42-01BORIN,\%20M.pdf

BOURDIEU, Pierre e SAINT-MARTIN, Monique de. Gostos de classe e estilos de vida. In: ORTIZ, Renato (org.). Bourdieu - Sociologia. São Paulo: Ática. Coleção Grandes Cientistas Sociais, vol. 39, 1983, p.82-121

BOURDIEU, Pierre. A Distinção: crítica social do julgamento. São Paulo/Porto Alegre: Edusp e Ed. Zouk, 2007.

BOURDIEU, Pierre. Condição de classe e posição de classe. In: BOURDIEU, Pierre; MICELLI, Sergio (org.). A economia das trocas simbólicas. São Paulo: Ed. Perspectiva, 2007, p. 3-27.

BOURDIEU, Pierre. Esboço de uma auto-análise. São Paulo: Cia das Letras, 2005.

BOURDIEU, Pierre. Estrutura, habitus e prática. In: BOURDIEU, Pierre; MICELLI, Sergio (org.). A economia das trocas simbólicas. São Paulo: Ed. Perspectiva, 2007, p. 337-361.

BOURDIEU, Pierre.Campo do poder, campo intellectual e habitus de classe. In: BOURDIEU, Pierre; MICELLI, Sergio (org.). A economia das trocas simbólicas. São Paulo: Ed. Perspectiva, 2007, p. 183-203.

BRESCIANI, M. Stella. Melhoramentos entre intervenções e projetos estéticos: São Paulo (1850-1950). In: BRESCIANI, M. Stella (Org.). Palavras da cidade. Porto Alegre: Editora da Universidade/UFRGS, 2001.

BRITO, Monica Silveira. Modernização e tradição: urbanização, propriedade de terra e crédito hipotecário em São Paulo na segunda metade do século XIX. São Paulo: FFLCH - USP (Tese de doutorado), 2006.

BRITO, Mônica Silveira. Participação da iniciativa privada produção do espaço urbano: São Paulo, 1890-1911. Dissertação (Mestrado) - FFLCH-USP, São Paulo, 2000

BUENO, Beatriz. Arqueologia da Paisagem: SIG Histórico e Mercado Imobiliário. Reconstituição do Centro Histórico de São Paulo (1809-1942). Anais do XIV SHCU, 2016. Disponível em: http://www.iau.usp.br/shcu2016/anais/wpcontent/uploads/pdfs/44.pdf

CAMPOS NETO, Candido Malta. Os rumos da cidade: urbanismo e modernização em São Paulo. São Paulo: ed. Senac, 2000. 
CAMPOS, Eudes de Mello. Arquitetura paulistana sob o império : aspectos da formação da cultura burguesa em São Paulo. Tese (Doutorado) - FAUUSP, São Paulo, 1997.

CAMPOS, Eudes. Casas e vilas operárias paulistanas situação da moradia da classe trabalhadora no final do Império. Informativo do Arquivo Histórico Municipal. São Paulo, jul/ago,, ano 4, n. 19 (versão digital). Disponível em: http://www.arquiamigos.org.br/info/info19/i-estudos.htm (ultimo acesso em fevereiro de 2017).

CAMPOS, Eudes. Chalés paulistanos. Anais do Museu Paulista, v.16, n.1, p. 47-108, 2008,

CAMPOS, Eudes. Nos caminhos da Luz, antigos palacetes da elite paulistana. Anais do Museu Paulista, São Paulo, v. 13, n. 1, p. 11-57, Jun. 2005

CAMPOS, Eudes. Os Pais de Barros e a Imperial Cidade de São Paulo. Informativo do Arquivo Histórico Municipal. São Paulo, jan/fev. 2008, ano 3, n. 16. Disponível em: http://www.arquiamigos.org.br/info/infol6/i-estudos.htm (Acessado pela última vez em fevereiro de 2017).

CANO, Wilson. Raízes da concentração industrial em São Paulo. (Tese de doutorado) - IFCH - UNICAMP, Campinas, 1990.

CARPINTÉRIO, Marisa Varanda Teixeira. Imagens do conforto: a casa operária nas primeiras décadas do séc. XX em São Paulo. In: BRESCIANI, Stella (org.). Imagens da Cidade. São Paulo: Ed. Marco Zero, 1994.

CARPINTERIO, Marisa Varanda Teixeira e CERASOLI, Josianne Francia. A cidade como história. História: Questões \& Debates, Curitiba, n. 50, p. 61-101, jan./jun. 2009. Editora UFPR.

CARVALHO, José Murilo de. A formação das almas: o imaginário da República no Brasil. São Paulo: Companhia das Letras, 1990.

CARVAlHO, Maria Cristina Wolff de. Bem-morar em São Paulo, 1880-1910: Ramos de Azevedo e os modelos europeus. São Paulo: Anais do Museu Paulista, v. 4, p. 165-200, jan./dez. 1996

CARVALHO, Vania Carneiro de. Gênero e Artefato: o sistema doméstico na perspectiva da cultura material - São Paulo 1870-1920. São Paulo: Edusp, 2008

CASTRO, Ana Claudia Scaglione.Veiga de. Um americano na metrópole (latinoamericana): Richard Morse e a história cultural urbana de São Paulo, 19471970. Tese (Doutorado), FAU-USP, São Paulo, 2013.

CASTRO, Ana Claudia Veiga de. A São Paulo de Menotti del Picchia. São Paulo: Ed. Alameda, 2008.

CERRI, Luis Fernando. Festas nacionais: uso e ditatização do saber histórico nas pedagogias do cidadão. HISTÓRIA \& E'1SI'IO. Londrina, v. 9, p. 205-222, out. 2003.

CERTEAU, Michel de. A invenção do cotidiano. Petrópolis: Ed. Vozes da Cidade, 1998.

CERASOLI, Josianne Francia. Modernização no plural: obras públicas, tensões sociais e cidadania na passagem do século XIX para o XX. Tese (Doutorado) - IFCHUNICAMP, 2004. 
CHALHOUB, Sidney. Trabalho, lar e botequim: o cotidiano dos trabalhadores no Rio de Janeiro da Belle Époque. Campinas: Ed. Unicamp, 2008.

CHARTIER, Roger. História Cultural: entre práticas e representações Lisboa: DIFEL, 1988.

CORBIN, Alain. O segredo do individuo. In: PERROT, Michelle (org.). História da vida privada: da Revolução Francesa à Primeira Guerra. São Paulo: Cia das Letras, 1992, p. 419-502.

CORDEIRO, Simone Lucena. Os Cortiços de Santa Ifigênia: sanitarismo e urbanização. São Paulo: Imprensa Oficial e Arquivo Publico do Estado de São Paulo, 2010.

CORREIA, Telma de Barros. A construção do habitat moderno no Brasil - 1870-1950. São Carlos: RiMa, 2004.

COSTA, Angela Marques da e SCHWARTZ, Lilia Moritz. 1890-1914: no 2 certezas. São Paulo: Cia das Letras, 2000.

DIAS, Maria Odila Leite da Silva. Quotidiano e poder em São Paulo no séc. XIX. São Paulo: Brasiliense, 1984.

DIETRICH, Ana Maria. Imagens de Sao Paulo: Gaensly no acervo da Light, 18991925. São Paulo: Fundação Patrimônio Histórico da Energia de São Paulo, 2011.

FABRIS, Annateresa. Arquitetura eclética no Brasil: o cenário da modernização. São Paulo: Anais do Museu Paulista,vol. 1 (nova série), 1993, p. 136.

FAUSTO, Boris. Uma paixão de outrora. Revista Piauí, edição 70, jul. 2012. Disponível em: http://piaui.folha.uol.com.br/materia/uma-paixao-de-outrora/

FERREIRA, Antônio Celso. A epopeia bandeirante: letrados, instituições, invenção histórica (1870-1940). São Paulo: Editora UNESP, 2002.

FERREIRA, Pedro Beresin Schleder. Disputas na representação de um "bairro aristocrático". XIV Seminário de História da Cidade e do Urbanismo. Anais, IAU-USP, São Carlos, 2016. Disponível em: http://www.iau.usp.br/shcu2016/anais/wp-content/uploads/pdfs/58.pdf

FONSECA, Guido. História da Prostituição em São Paulo. São Paulo: Resenha Universitária, 1982.

FORTY, Adrián.Higiene e limpeza. In: Objeto de desejo - design e sociedade 1750. São Paulo: Cosac Naify, 2007, pp. 215-246

FREHSE, Fraya. Cartões postais paulistanos na virada do século XX: problematizando a São Paulo “moderna”. Horizontes Antropológicos, Porto Alegre, ano 6, n. 13, p. 127-153, jun. 2000.

FREHSE, Fraya. Ô da rua: o transeunte e o advento da modernidade. São Paulo, Edusp, 2011.

FREIRE, Jurandir da Costa. Ordem médica e norma familiar. Rio de Janeiro: Graal, 1989

FREUD, Sigmund. O chiste e sua relação com o inconsciente. Rio de Janeiro: Ed. Imago, 2006.

FREUD, Sigmund. A negação. São Paulo: Cosac Naify, 2014.

FREUD, Sigmund. As pulsões e seus destinos. São Paulo: Ed. Autêntica, 2013. 
FRYKMAN, Jonas. Culture Builders: A Historical Anthropology of Middle-class Life. Nova Jersey: Rutgers University Press, 1987

FUNARI, Pedro Paulo Abreu. A cultura brasileira e a construção da mitologia bandeirante. In: Ideias, ano 2, n. 1, Campinas, UNICAMP, 1995.

GAY, Peter. A educação dos sentidos. São Paulo: Cia das Letras, 1999

GAY, Peter. Freud para historiadores. Rio de Janeiro: Ed. Paz e Terra, 1989.

GAY, Peter. O século de Schnizler. A formação da cultura de classe média. 1815-1914. São Paulo: Companhia das Letras, 2002.

GENNARI, Luciana Alem. As casas em série do Brás e da Mooca: um aspecto da constituição da cidade de São Paulo. Dissertação (Mestrado) - FAU-USP, 2005.

GERODETTI, João Emílio e CORNEJO, Carlos. Lembranças de São Paulo. São Paulo: Solaris, 2002.

GINZBURG, Carlo. "Sinais: raízes de um paradigma indiciário” In Mitos, emblemas, sinais: Morfologia e História. São Paulo: Companhia das Letras, 1990.

GROSTEIN, Marta Dora. A cidade clandestina: os ritos e os mitos. São Paulo: Faculdade de Arquitetura e Urbanismo da Universidade de São Paulo (Tese de Doutorado), 1987.

HADLER, Maria. Trilhos de modernidade: memórias e educação urbana dos sentidos. Tese (Doutorado) - FE-UNICAMP, 2007, p. 37.

HALL, Catherine. Sweet Home. In: PERROT, Michele (org.). História da Vida Privada: da Revolução Francesa à Primeira Guerra. São Paulo: Cia das Letras, 1992, vol. 4.

HELLMAN, Mimi. Interior motives: seduction by decorationin eighteen- century France. In: KODA, Harold et al. Dangerous liasons Fashion and Furniture in the Eighteenth Century. Nova York: Metropolitan Museum of Art, 2006, p. 15-25.

HOMEM, Maria Cecília Naclério. Higienópolics: grandeza e decadência de um bairro paulistano. São Paulo: PMSP, 1980.

HOMEM, Maria Cecilia Naclério. O palacete paulistano e outras formas de morar da elite cafeeira. São Paulo: Ed. Martins Fontes, 1996.

KARASCH, Mary C. A vida dos escravos no Rio de Janeiro (1805-1850). São Paulo: Companhia das Letras. 2001.

KOSSOY, Boris. A São Paulo fotogênica de Guilherme Gaensly. In: Guilherme Gaensly. São Paulo: Ed. Cosac Naify, 2011

KUVASNEY, Eliane. Os mapas como “operadores espaciais” na construção da cidade de São Paulo do início do século XX. Revista do Instituto de Estudos Brasileiros, Brasil, n. 64, p. 167-182, ago. 2016.

LANNA, Ana Lúcia Duarte. Uma cidade na transição: Santos 1870-1913. São Paulo: Hucitec, 1995.

LEME, Luiz Gonzaga da Silva. Geneloagia Paulistana. São Paulo: Ed. Duprat, 1905.

LEMOS, Carlos A. C. Alvenaria burguesa. São Paulo: Ed. Nobel, 1986.

LEMOS, Carlos A.C. A república ensina a morar (melhor). São Paulo : Hucitec, 1999.

LEPETIT, Bernard; SALGUEIRO, Heliana Angotti (org.). Por uma nova história urbana. São Paulo: Edusp, 1996 
LEPETIT, Bernard. A história leva os atores a sério? In: LEPETIT, Bernard; SALGUEIRO, Heliana Angotti (org.). Por uma nova história urbana. São Paulo: Edusp, 1996, p. 227-244.

LEPETIT, Bernard. Arquitetura, Geografia, História: usos da escala. In: LEPETIT, Bernard; SALGUEIRO, Heliana Angotti (org.). Por uma nova história urbana. São Paulo: Edusp, 1996, p. 191-226.

LEVI, Darrel.A família Prado. São Paulo: Cultura 70, 1977.

LIERNUR, Jorge Francisco. Casas y jardines: la construcción del dispositivo doméstico moderno in Historia de la vida privada: la Argentina plural, vol. 2 (org. Fernando Devoto e Marta Madero). Buenos Aires: Taurus, 1999.

LIMA, Solange Ferraz de. São Paulo na virada do século. As imagens da razão urbana: a cidade nos álbuns fotográficos de 1887 a 1919. Dissertação (Mestrado) FFLCH-USP, 1995.

LIMA, Solange Ferraz, CARVALHO, Vania Carneiro de. Fotografia e cidade: da razão urbana a lógica de consumo. São Paulo: Mercado de Letras, 1997.

LIMA, Solange Ferraz. O trânsito dos ornatos: modelos ornamentais da Europa para o Brasil seus usos (e abusos?). In: Anais do Museu Paulista, v. 16, p. 145-192, 2008.

LIMA, Solange Ferraz. Ornamento e cidade: ferro, estuque e pintura mural. São Paulo, 1870-1930. (tese de Doutorado defendida em 2002).

LODY, Jorge. Arquitetura e Cidade: obras particulares em São Paulo 1906-1915. Tese (Doutorado) - FAU-USP, São Paulo, 2015.

LOTITO, Márcia Padilha. A cidade como espetáculo: publicidade e vida urbana na São Paulo dos anos 20. São Paulo, 1997. Dissertação (Mestrado) - Faculdade de Filosofia, Letras e Ciências Humanas, Universidade de São Paulo.

LOYER, François. Paris XIXe siècle. L'immeuble et la rue. Paris: Hazan, 1987.

LUCA, Tania Regina de. História dos, nos e por meio dos periódicos.In: PINSKY, Carla Bassanezi (Org.). Fontes históricas. São Paulo: Contexto, 2005. p. 111153.

MALTA, Marize. O olhar decorativo: ambientes domésticos em fins do século XIX no Rio de Janeiro. Rio de Janeiro: Mauad X: Faperj, 2011

MARINO, Carlos Eduardo Collet. O ócio e o lazer na São Paulo da Belle Époque: a vilegiatura marítima e a invenção do Guarujá enquanto balneário da metrópole (1890-1915). Relatório de Qualificação de Mestrado, FAU-USP, São Paulo, 2016.a

MARINS, Paulo César Garcez. Através da rótula: sociedade e arquitetura no Brasil, séculos XVII a XX. Tese (Doutorado em História Social) - FFLCH, Universidade de São Paulo, São Paulo, 1999.

MARINS, Paulo César Garcez. Habitação e vizinhança: limites da privacidade no surgimento das metrópoles brasileiras. In: NOVAIS, Fernando e SEVCENKO, Nicolau (org.). História da vida privada no Brasil - República: da Belle Époque à era do rádio. São Paulo: Cia das Letras, 2006, p. 131-215.

MARINS, Paulo Cesar Garcez. La avenida Paulista de la Belle Époque: elites en disputa. In: GORELIK, Adrián e PEIXOTO, Fernanda Arêas (org.). Ciudades latino-americanas como arenas culturales. Buenos Aires: Siglo XXI, 2016. 
MARINS, Paulo César Garcez. Um lugar para as elites: os Campos Elíseos de Glette e Nothmann no imaginário urbano de São Paulo. IN: LANNA, A. et al (org.).São Paulo, os estrangeiros e a construção das cidades. São Paulo: Ed. Alameda, 2011.

MARQUETTI, Fernanda Cristina. O suicídio como espetáculo na metrópole: cenas, cenários e espectadores. São Paulo: Editora Fap-Unifesp, 2011,

MARQUETTI, Fernanda. O suicídio e sua essência transgressora. Psicologia USP, São Paulo, v.25, n. 3, 2014, p. 237-245.

MELLO, Joana. Da arqueologia portuguesa à arquitetura brasileira. São Paulo: Annablume, 2007.

MELLO, Marco Antonio da Silva; SIMÕES, Soraya Silveira. "Onde você mora?": propósitos e implicações do endereço. In: Duarte, Cristiane Rose; VILLANOVA, Roselyne de (org.). Novos olhares sobre o lugar. Rio de Janeiro: Ed. Contracapa/FAPERJ, 2013, pp. 65-81.

MELO, Victor Andrade. Lazer, modernidade e capitalismo: um olhar a partir da obra de Edward Palmer Thompson. Revista Estudos Históricos, Rio de Janeiro, vol. 23, n ${ }^{\circ} 45$, p. 5-26, jan/jun 2010.

MENDES, Ricardo. S.A.R.A. Brasil: restituindo o Mapa Topográfico do Município de São Paulo. Informativo do Arquivo Histórico de São Paulo. São Paulo, Ano 10, $\mathrm{n}^{0}$ 37, dez. 2014.

MENDES, Ricardo. Uma cidade em obras. In: FERRAZ, Vera Maria de Barros (org.). Imagens de São Paulo : Gaensly no acervo da Light, 1899-1925. São Paulo : A Fundação, 2001.

MENESES, Ulpiano Bezerra de. Cultura material no estudo das sociedades antigas. Revista de História, São Paulo, n. 115, p. 103-117, 1985.

MENESES, Ulpiano Bezerra de. Do teatro da memória ao laboratório da História: a exposição museológica e o conhecimento histórico. São Paulo: Anais do Museu Paulista, 1994, vol. 2, no 1.

MENESES, Ulpiano Bezerra de. Memória e Cultura Material: documentos pessoais no espaço público. São Paulo: Revista Estudos Históricos, CPDOC/FGV, 1998, vol. 11 , no 21.

MENESES, Ulpiano Bezerra de. Prefácio. In: CARVALHO, Vânia Carneiro de. Gênero e Artefato: O Sistema Doméstico na Perspectiva da Cultura Material. São Paulo, 1870-1920. São Paulo: Edusp, 2008.

MENEZES, Ulpiano Toledo Bezerra de. A cidade como bem cultural: áreas envoltórias e outros dilemas, equívocos e alcance da preservação do patrimônio ambiental urbano. In: Vitor Hugo Mori et al (Orgs.). Patrimônio: Atualizando o Debate. São Paulo: 9a SR/ IPHAN, 2006.

MENEZES, Ulpiano Toledo Bezerra de. Morfologia das cidades brasileiras: introdução ao estudo histórico da iconogra a urbana. Revista USP, São Paulo, n. 30, junago, 1996, p. 145-55.

MESENES, Ulpiano T. Bezerra de. Cultura material no estudo das sociedades antigas. Revista de História, São Paulo, n. 115, 1985, p. 113.

MOBEIG, Pierre. La croissance de la ville de São Paulo (1953). In: Revue de Geographie Alpine, 1953. 
MORSE, Richard. De comunidade a metrópole: biografia de São Paulo. São Paulo: Comissão do IV Centenário de São Paulo, 1954.

MOSCOVICI, Serge. Representações Sociais: Investigações em Psicologia Social. Petrópolis: Vozes, 2009.

MOURA, Clóvis. Dicionário da escravidão negra no Brasil. São Paulo: Edusp. 2004.

NASCIMENTO, Ana Paula. Samuel das Neves: engenharia, urbanismo e periodismo. VII Seminário Nacional do Centro de Memória, Campinas. Anais: Campinas, Unicamp, 2016.

OLIVEIRA, Lúcia Maria Lippi. Imaginario Historico e Poder Cultural: as comemorações do Descobrimento. Revista Estudos Históricos, v.14, n. 26, 2000.

OLIVEIRA, Maria Luisa Ferreira de. Entre a casa e o armazém. Relações sociais e experiência de urbanização: São Paulo, 1850-1900. São Paulo: Ed. Alameda, 2005.

OLIVEIRA, Saulo Veiga e ODA, Ana Maria Galdini Raimundo. O suicídio de escravos em São Paulo nas últimas duas décadas da escravidão. História, Ciências, Saúde - Manguinhos, Rio de Janeiro, v.15, n.2, p.371-388, abr/jun. 2008.

OLIVEIRA, Saulo Veiga. Suicídios de escravos em Campinas e na província de São Paulo (1870-1888). Dissertação (Mestrado) - Universidade Estadual de Campinas, Campinas, 2007.

PEREIRA, Robson Mendonça. O Prefeito do progresso: modernização da cidade de São Paulo na administração de Washigton Luís. Tese (Doutorado) - FHDSSUNESP, 2005.

PERROT, Michelle. Maneiras de morar. In: PERROT, Michelle (org.). História da Vida Privada: da Revolução Francesa à Primeira Guerra. São Paulo: Cia das Letras, 1992, p. 284-302.

PESAVENTO, Sandra Jatahy. Exposições Universais-Espetáculos da Modernidade do século XIX. São Paulo: Hucitec, 1997.

PETERS, Gabriel. Configurações e reconfigurações na teoria do habitus: um percurso. XIV Congresso Brasileiro de Sociologia. Anais: Rio de Janeiro, 2009.

PINTO, Maria Inez Machado Borges. Crônica cinematográfica do cotidiano: Alcântara Machado e os impasses do modernismo. Varia História, Belo Horizonte, $\mathrm{n}^{\circ}$ 24, Jan, 2001, p.190-209.

PONTES, Nicole Louise Madero Teles de. Habitus e libido social: revisando Bourdieu através da psicanálise. Estudos de Sociologia - Revista do Programa de PósGraduação em Sociologia da UFPE, vol. 2, n. 17, 2011 (versão digital). Disponível

em:

http://www.revista.ufpe.br/revsocio/index.php/revista/article/view/42/33

PRADO JR. Caio. Nova contribuição para o estudo geográfico da cidade de São Paulo. Estudos Brasileiros, ano III, vol. 7, no 19-21, Rio de Janeiro, 1941.

PROST, Antoine. A família e o individuo. In: PROST, Antoine e VINCENT, Gérard, História da Vida Privada: da Primeira Guerra aos nossos dias. São Paulo: Cia das Letras, 1992, vol. 5, p. 61-115. 
PROST, Antoine. O trabalho. In: PROST, Antoine e VINCENT, Gérard. História da Vida Privada: da Primeira Guerra aos nossos dias. São Paulo: Cia das Letras, 1992, vol. 5, p. 21-61

RAGO, Margareth. Os prazeres da noite: prostituição e códigos da sexualidade feminina em São Paulo, 1890-1930. Rio de Janeiro: Ed. Paz e Terra, 2008.

RIBEIRO, Luiz Cesar de Queiroz. Dos cortiços aos condomínios fechados. Rio de Janeiro: Civilização Brasileira, 1997.

RICE, Charles. The emergence of the interior: architecture, modernity, domesticity. London: Routledge, 2007.

ROLNIK, Raquel. A cidade a lei. São Paulo: Studio Nobel, 1997.

SAFATLE, Vladimir. Aquele que diz "não": sobre um modo peculiar de falar de si. In: FREUD, Sigmund. A negação. São Paulo: Cosac Naify, 2014, p.36.

SALGUEIRO, Heliana Angotti. Figures de la patrie: la symbolique de léspace republicain. In: La casaque d'Arlequin: Belo Horizonte, une capitale écletique au $19^{\mathrm{e}}$ siècle. Paris: Editions de l'EHESS, 1997, p. 103-118.

SALGUEIRO, Heliana Angotti. La casaque d'Arlequin: Belo Horizonte, une capitale écletique au 19e siècle. Paris: Editions de l'EHESS, 1997.

SANTOS, Alessandra Xavier dos; SILVA, Andressa Amaral da; DANTAS, Wesley Nunes (org.). Ricardo Severo: “A Arte Tradicional no Brasil”. [Originalmente publicado em Revista do Brasil, São Paulo, ano II, vol. 4, jan.-abr. 1917, p.394424. Texto com grafia atualizada]. 19\&20, Rio de Janeiro, v. VII, n. 1, jan./mar. 2012.

SANTOS, Isabel dos. Brás, Bexiga e Barra Funda de Alcântara Machado: uma narrativa-registroda cidade de São Paulo. Dissertação (Mestrado) - PUC-SP, São Paulo, 2010.

SANTOS, Joao Marcelo Pereira dos. Os trabalhadores da Light São Paulo, 1900-1935. Tese (Doutorado) - IFCH-UNICAMP, 2009.

SANTOS, Simone Andriani. Senhoras e criadas no espaço doméstico São Paulo (18751928). Dissertação (Mestrado) - FFLCH-USP, 2015.

SCHORSKE, Carl. Da cena pública ao espaço privado: a arquitetura como crítica cultural. In: SCHORSKE, Carl. Pensando com a História. São Paulo: Cia das Letras, 2000, p.179-194.

SCHORSKE, Carl. Pensando com a História. São Paulo: Cia das Letras, 2000.

SENNET, Richard. Boundaries and borders. In: BURDETT, Ricky e SUDJIC, Deyan (org.) Living in the endless city. Londres: Phaidon Press, 2011, p. 324-331.

SEVCENKO, Nicolau. A revolta da vacina: mentes insanas em corpos rebeldes. São Paulo: Cosacnaify, 2010.

SEVCENKO, Nicolau. Introdução: o prelúdio republicano, astúcias da ordem e ilusões do progresso. In: NOVAIS, Fernando e SEVCENKO, Nicolau (org.). História da vida privada no Brasil - República: da Belle Époque à era do rádio. São Paulo: Cia das Letras, 2006, p. 7-49.

SEVCENKO, Nicolau. O cosmopolitismo pacifista da Bele Époque: uma utopia liberal. In: Revista de História, n. 114, USP, São Paulo: janeiro-junho, 1983

SEVCENKO, Nicolau. Orfeu extático na metrópole: São Paulo, sociedade e cultura nos frementes anos 20. São Paulo: Cia das Letras, 1992. 
SILVA, Joana Mello de Carvalho e e FERREIRA, Pedro Beresin Schleder. Os sentidos do morar em três atos: representação, conforto e privacidade (ainda inédito).

SILVA, Joana Mello de Carvalho; FERREIRA, Pedro Beresin Schleder et al.. A residência Franco de Mello em três tempos: da domesticidade belle époque ao Centro de Cultura, Memória e Estudos da Diversidade Sexual do Estado de São Paulo. Revista CPC, n. 20, 2015.

SILVA, João Luis Máximo da. Cozinha modelo: o impacto do gás e da eletricidade na Casa Paulistana, (1870-1930). São Paulo: Edusp, 2008.

SILVA, João Luiz Maximo da. Transformações no espaço doméstico: o fogão a gás e a cozinha paulistana, 1870-1930. Sâo Paulo:Anais do Museu Paulista, 2007, vol.15, n.2.

SIMMEL, Georg. As grandes cidades e a vida do espirito. Mana vol.11 no.2 Rio de Janeiro Oct. 2005.

SIMONI, Lucia Noemia. A planta da cidade de São Paulo de 1897: uma cartografia da cidade existente ou da cidade futura?. In: SIMPÓSIO LUSO-BRASILEIRO DE CARTOGRAFIA HISTÓRICA. Anais: Ouro Preto: UFMG, 2009

SIMONI, Lucia Noemia. O arruamento de terras e o processo de formação do espaço urbano no município de São Paulo, 1840-1930. Tese (Doutorado) - FAU-USP, São Paulo, 2002.

TELAROLLI JUNIOR, Rodolpho. Imigração e epidemias no estado de São Paulo. Hist. cienc. saude-Manguinhos [online]. 1996, vol.3, n.2 , p. 265-283

TERRA, Paulo Cruz. Conflitos cotidianos e motins: os usuários de bondes no Rio de Janeiro no final do século XIX e início do XX. História Social, n. 22 e 23, Campinas, 2012.

THEODORO, Janice. São Paulo de Ramos de Azevedo: da cidade colonial à cidade romântica. São Paulo: Anais do Museu Paulista, v. 4, p. 201-208, jan./dez. 1996.

THIRY-CHERQUES, Hermano Roberto. Pierre Bourdieu: teoria na prática. Revista de Administração Pública, EBAPE-FGV, Rio de Janeiro, jan./fev. 2006.

THOMPSON, Edward Palmer. A miséria da teoria ou um planetário de erros: uma crítica ao pensamento de Althusser. Rio de Janeiro: Zahar Editores, 1978.

THOMPSON, Edward Palmer. Tempo, disciplina de trabalho e o capitalismo industrial. In: THOMPSON, Edward Palmer. Costumes em comum. São Paulo: Cia das Letras, 1998.

VALENCIANO, Jésus Cruz. El surgimiento de la cultura burguesa. personas, hogares y ciudades en la españa del siglo XIX. Madrid: Siglo XXI, 2014

VEBLEN, Thorstein. A Teoria da Classe Ociosa: um estudo econômico das instituições. São Paulo: Ática, 1974. 
Arquivos consultados

Acervo digital d' O Estado de São Paulo.

Acervos dos diários Correio Paulistano, O Combate, A Federação, A Gazeta, O Commercio de São Paulo Il Moscone, Diário Español, e Diário Nacional na Hemeroteca Digital da Biblioteca Nacional.

Arquivo de Processos do Tribunal de Justiça de São Paulo Fundo de Obras Privadas do Arquivo Municipal de São Paulo.

Repositório Digital do Arquivo Público do Estado de São Paulo.

Repositório Digital do Arquivo Histórico Municipal de São Paulo.

Acervo Digital de Leis da Câmara Municipal de São Paulo

Dicionário de Ruas do Arquivo Municipal de São Paulo

Fundo da Prefeitura do Arquivo Municipal de São Paulo 

$* * *$ 



\section{Agradecimentos}

Primeiramente, agradeço à minha orientadora, Ana Lanna, norte vibrante e porto seguro desta travessia. Através de seus caminhos, começo a dar meus primeiros passos.

À Joana Mello, pelos ensinamentos, pelas aventurosas incursões nos mistérios da vida doméstica e, sobretudo, pela generosidade, amizade e parceria.

À Josianne Cerasoli e ao Paulo Garcez, pela leitura atenta e generosa na qualificação, que resultou nos desafios e provocações que empregaram vigoroso impulso ao meu trabalho.

À Ana Castro e à Amália dos Santos, pelas intensas e vivazes trocas, pela amizade e pelos ensinos.

À Clarissa Paulillo e à Deborah Caramel pelas instigantes discussões sobre cultura material e domesticidade e pelo companheirismo nesta travessia, pelo que sou igualmente grato a Juliane Bellot, Cadu Marino, Thales Marreti e Otávio Melo.

À Fernanda Pitta, Renato Cymbalista, Eduardo Costa, Marianna Boghosian, Pedro Lopes, Fábio Mosaner e Glória Kok, pelas trocas instigantes, pelo acolhimento e pela partilha da experiência.

Ao amigo Pedro Lotti, pelas longas e irrequietas conversas adentro dos vastos mundos da linguagem e do pensamento.

À Lena Império, pela parceria nas ideias e na vida, pela leitura atenta e pelos conselhos decisivos nessa reta final.

À CAPES, pela bolsa que me permitiu toda a dedicação necessária.

Aos funcionários do Arquivo Histórico Municipal, do Arquivo do Tribunal de Justiça de São Paulo, do Tribunal de Justiça e do Acervo da FAU, pela paciência e receptividade. Aos funcionários da Biblioteca Mário de Andrade, graças a vocês encontrei minha segunda casa na cidade.

Aos queridos amigos, que mesmo longe nunca saem de perto.

Aos avós Rifka, Abrahão e Regina, meus faróis luminosos.

Ao meu pai, Nelson, que me transmitiu o ávido desejo de explorar a Terra, e que agora foi abrir caminhos em outros mundos.

À Maria, pela paciência, pelo acolhimento, pela arte e, sobretudo, por me agraciar com sua peculiar sabedoria.

Ao Dani, pela irmandade à sua maneira.

À minha mãe, Ruth, pedra angular de toda a vida. 